\title{
FIXED-BED GASIFIER AND CLEANUP SYSTEM ENGINEERING SUMMARY REPORT THROUGH TEST RUN NO. 100
}

\author{
By \\ K. Pater, Jr., Project Manager \\ L. Headley \\ J. Kovach \\ D. Stopek
}

JUNE 1984

For

U. S. Department of Energy

Office of Fossil Energy

Morgantown Energy Technology Center

Morgantown, West Virginia

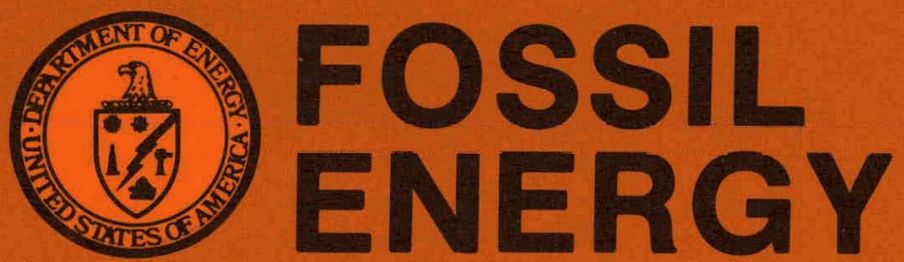

TECHNICAL INFORMATION CENTER

OFFICE OF SCIENTIFIC AND TECHNICAL INFORMATION UNITED STATES DEPARTMENT OF ENERGY 


\section{DISCLAIMER}

This report was prepared as an account of work sponsored by an agency of the United States Government. Neither the United States Government nor any agency Thereof, nor any of their employees, makes any warranty, express or implied, or assumes any legal liability or responsibility for the accuracy, completeness, or usefulness of any information, apparatus, product, or process disclosed, or represents that its use would not infringe privately owned rights. Reference herein to any specific commercial product, process, or service by trade name, trademark, manufacturer, or otherwise does not necessarily constitute or imply its endorsement, recommendation, or favoring by the United States Government or any agency thereof. The views and opinions of authors expressed herein do not necessarily state or reflect those of the United States Government or any agency thereof. 


\section{DISCLAIMER}

Portions of this document may be illegible in electronic image products. Images are produced from the best available original document. 


\title{
DISCLAIMER
}

\begin{abstract}
This report was prepared as an account of work sponsored by an agency of the United States Government. Neither the United States Government nor any agency thereof, nor any of their employees, makes any warranty, express or implied, or assumes any legal liability or responsibility for the accuracy, completeness, or usefulness of any information, apparatus, product, or process disclosed, or represents that its use would not infringe privately owned rights. Reference herein to any specific commercial product, process, or service by trade name, trademark, manufacturer, or otherwise does not necessarily constitute or imply its endorsement, recommendation, or favoring by the United States Government or any agency thereof. The views and opinions of authors expressed herein do not necessarily state or reflect those of the United States Government or any agency thereof.
\end{abstract}

This report has been reproduced directly from the best available copy.

Available from the National Technical Information Service, U. S. Department of Commerce, Springfield, Virginia 22161.

Price: Printed Copy A07

Microfiche A01

Codes are used for pricing all publications. The code is determined by the number of pages in the publication. Information pertaining to the pricing codes can be found in the current issues of the following publications, which are generally available in most libraries: Energy Reseurch Abstructs (ERA); Government Reports Announcements and Index (GRA and I); Scientific and Technical Abstract Reports (STAR); and publication NTIS-PR-360 available from NTIS at the above address. 
DOE/METC-84-19

(DE84009282)

Distribution Categories UC.90c, 90h, 90i

\title{
FIXED-BED GASIFIER AND CLEANUP SYSTEM ENGINEERING SUMMARY REPORT THROUGH TEST RUN NO. 100
}

\author{
By \\ K. Pater, Jr., Project Manager \\ L. Headley \\ J. Kovach \\ D. Stopek
}

JUNE 1984

For

U. S. Department of Energy

Office of Fossil Energy

Morgantown Energy Technology Center

P. O. Box 880

Morgantown, West Virginia 26505 


\section{THIS PAGE \\ WAS INTENTIONALLY \\ LEFT BLANK}


The state-of-the-art of high-pressure, fixed-bed gasification has been advanced by the many refinements developed over the last 5 years. A novel ful1-flow gas cleanup system has been installed and tested to clean coal-derived gases. This report summarizes the results of tests conducted on the gasifier and cleanup system from its inception through 1982. Selected process summay data are presented along with results from complementary programs in the areas of environmental research, process simulation, analytical methods development, and component testing. 
THIS PAGE

\section{WAS INTENTIONALLY LEFT BLANK}




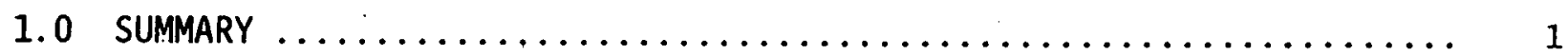

1.1 Overview ...................................... 1

1.2 Program Accomplishments ................................ 3

1.3 Goals for Fiscal Years 1983 and $1984 \ldots \ldots \ldots \ldots \ldots \ldots \ldots . . . \ldots . .10$

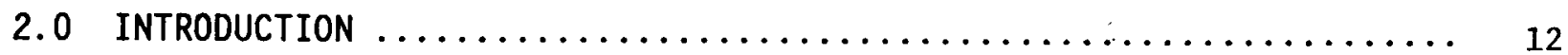

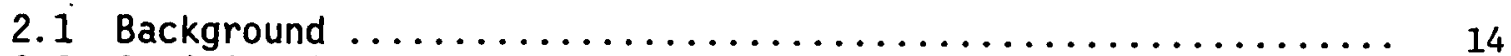

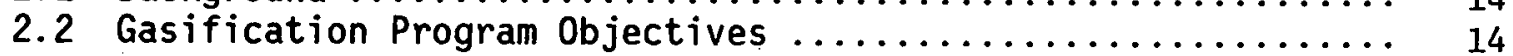

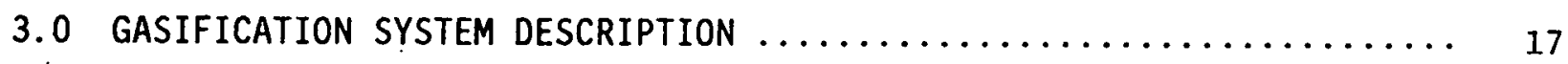

3.1 Gasification System Description...$\ldots \ldots \ldots \ldots \ldots \ldots \ldots \ldots \ldots \ldots \ldots$

3.2 Gas Cleanup System Description ....................... 24

3.2.1 Side-Stream Cleanup System ................... 24

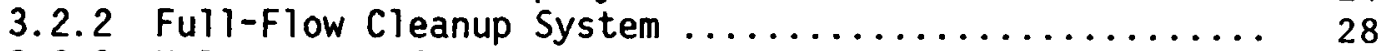

3.2.3 Holmes-Stretford Sulfur Removal System .......... 32

4.0 DESCRIPTION OF COMPLEMENTARY PROJECTS $\ldots \ldots \ldots \ldots \ldots \ldots \ldots \ldots \ldots \ldots \ldots \ldots \ldots \ldots$

4.1 Control System Improvements and Innovations ............. 35

4.2 Environmental Health and Safety Research ............... 37

4.2.1 Environmental Characterization and

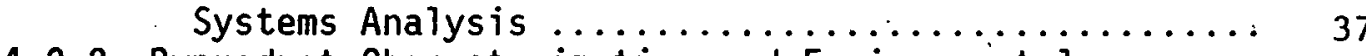

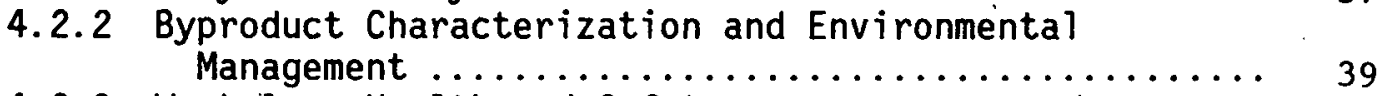

4.2.3 Workplace Health and Safety $\ldots \ldots \ldots \ldots \ldots \ldots \ldots . . . \ldots \ldots$

4.3 Chemical Analysis Data Base ...................... 40

4.4 Test Sámples for Other Programs $\ldots \ldots \ldots \ldots \ldots \ldots \ldots \ldots \ldots, 41$

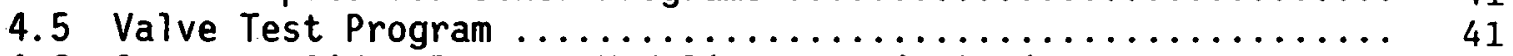

4.6 Computer-Aided Process Modeling and Simulation ............ 41

4.7 Corrosion/Erosion Test Program .................... 42

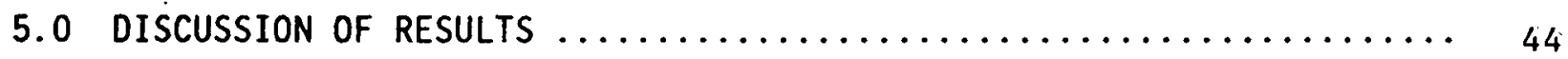

5.1 Gasifier System. Development $\ldots \ldots \ldots \ldots \ldots \ldots \ldots \ldots \ldots \ldots \ldots \ldots \ldots$

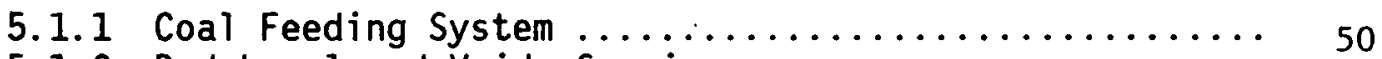

5.1 .2 Bed Level and Voids Sensing $\ldots \ldots \ldots \ldots \ldots \ldots \ldots \ldots, 50$

5.1 .3 Bed Stirrer ........................... 50

5.1.4 Grate Temperature Control ................... s2

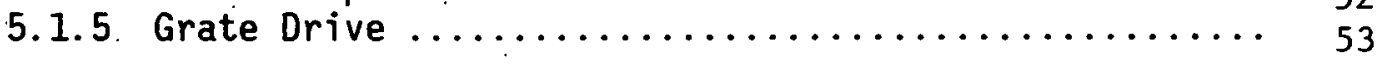


5.2 Side-Stream Cleanup System Test Results $\ldots \ldots \ldots \ldots \ldots \ldots \ldots . . \ldots 3$

5.2.1 First Side-Stream Cleanup Test Series ........... 54

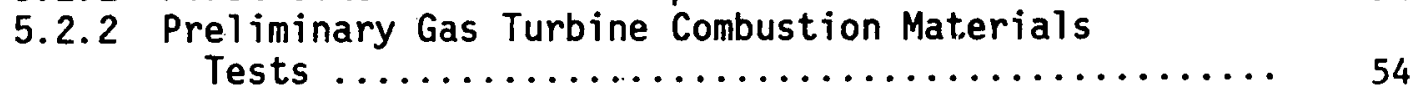

5.2.3 Second Side-Stream Cleanup Test Series ............ 56

5.2.4 Third Side-Stream Cleanup Test Series ............ 58

5.3 Full-Flow Cleanup System Test Results $\ldots \ldots \ldots \ldots \ldots \ldots \ldots \ldots, 62$

5.3.1 Phase III of the Test Program -- Initial Testing of Ful 1-Flow Components ..................... 65

5.3.2 Phase IV of the Test Program -- Complete Full-Flow Cleanup Test Results ...................... 68

5.4 Results from Complementary Projects $\ldots \ldots \ldots \ldots \ldots \ldots \ldots . . \ldots 6$

5.4.1 Environmental Health and Safety Research ......... 96

5.4.2 Chemical Analysis Data Base .................. 105

5.4.3 Process Modeling and Stimulation ............... 110

5.4.4 In-Service Valve Test Program .................. 114

5.4.5 Corrosion/Erosion Test Program .............. 114

6.0 GLOSSARY OF ACRONYMS AND ABBREVIATIONS $\ldots \ldots \ldots \ldots \ldots \ldots \ldots \ldots \ldots . . \ldots \ldots$

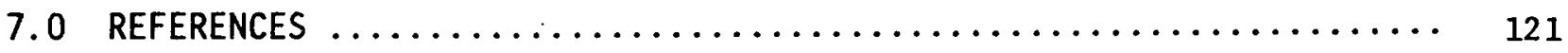

LIST OF FIGURES

1. METC Fixed-Bed Gasifier and Full-Flow Cleanup System

Process Flow Diagram ................................. 2

2. MFTC. Fixed-Bed Program Overview $\ldots \ldots \ldots \ldots \ldots \ldots \ldots \ldots \ldots \ldots \ldots, 4$

3. METC Fixed-Bed Gasification Plant Test Schedule for Run $101 \ldots \ldots .13$

4. METC Pressurized Gasifier and Coal Handling System $\ldots \ldots \ldots \ldots \ldots . . . . .18$

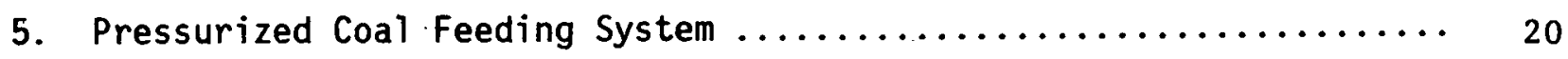

6. Farly Version of Fixed-Bed Gasifier ...................... 20

7. Sectional View of Current Fixed-Bed Gasifier $\ldots \ldots \ldots \ldots \ldots \ldots \ldots \ldots, 21$ 
8. Gasifier Reaction Zones $\ldots \ldots \ldots \ldots \ldots \ldots \ldots \ldots \ldots \ldots \ldots \ldots, 22$

9. First Side-Stream Gas Cleanup Train Configuration .............. 26

10. Turbine Materials -- Combustion Test Rig ................... 27

11. Modified Side-Stream Cleanup Configuration .................. 29

12. Current Configuration of Fixed-Bed Gasifier and

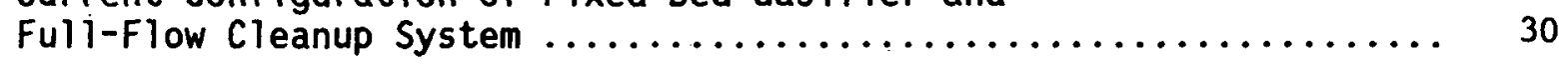

13. Stretford Hydrogen Sulfide Removal System $\ldots \ldots \ldots \ldots \ldots \ldots \ldots \ldots . . . \ldots . . .63$

14. Corrosion/Erosion Test Facility ........................ 43

15. Gasifier Test Configuration -- Phase I .................... 45

16. METC Fixed-Bed Gasifier -- Nuclear Level Detection Design ......... 51

17. Initial Full-Flow Cleanup Train Configuration with

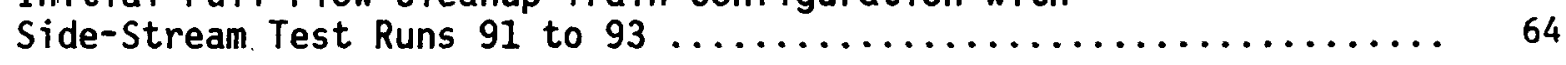

18. Fixed-Bed Gasifier and Full-Flow Cleanup System Runs 95 to 98 Configuration Tested in Run 94 --Inside Dashed Lines ............. 69

19. Sample Locations for Full-Flow Gas Cleanup System

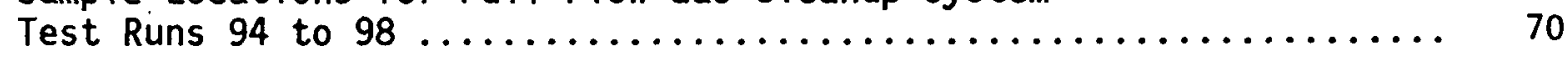

20. Electrostatic Precipitator ................................ 74

21. Size Distribution of Particulates in Process

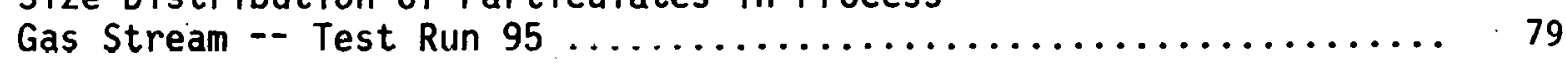

22. Test Run 97 Flow Diagram and Material and Energy Balance ........ 90

23. Test Run 98 Flow Diagram and Material and Energy Balance ......... 91

24. Sample Locations for Ful1-Flow Gas Cleanup

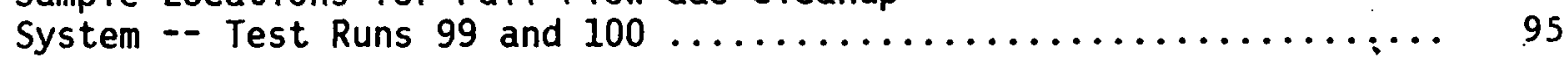

25. Stretford Performance Comparison -- Runs 99 and $100 \ldots \ldots \ldots \ldots . .67$

26. Comparison of Measured RCRA Parameters in Gasifier Ash with Limits for METC Fixed-Bed Gasification --

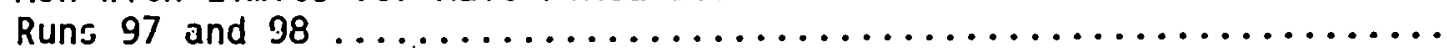

27. Distribution and Size of Aerosols Throughout Process Gas Streams 
28. Prediction of Product Gas Heating Value for METC

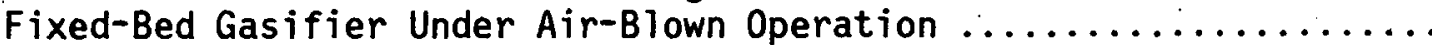

29. Prediction of Product Gas Heating Value for METC

Fixed-Bed Gasifier Under Oxygen-Blown Operation ...............

30. Model Prediction of Humidifier Wall Temperatures, Tar

Condensation Rate, and Center Line Temperatures as a Function

of Height

31. Comparison of Mode1 Predictions and Test Data for the

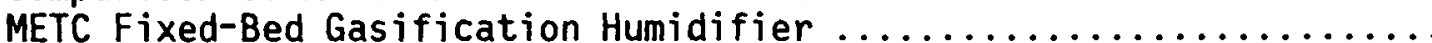

32. Computerized Aspen Process Flow Sheet Input for METC

Fixed-Bed Coal Gasification System

\section{LIST OF TABLES}

Page

1. Summary of Accomplishments and Goals for METC

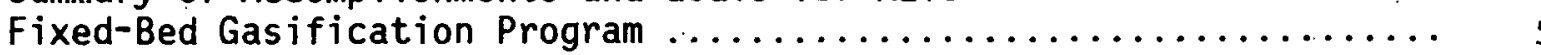

2. METC Stirred Fixed-Bed Gasifier and Full-Flow

Cleanup System Run Summary $\ldots \ldots \ldots \ldots \ldots \ldots \ldots \ldots \ldots \ldots \ldots \ldots \ldots \ldots \ldots$

3. Phase I of Test Program -- Analyses of Coals Tested .......... 46

4. Phase I of Test Program -- Gasifier Performance Under .

Pressurized Conditions on Various Coal Feeds $\ldots \ldots \ldots \ldots \ldots \ldots \ldots \ldots .48$

5. Gasification Performance Data Operating at Atmosphere and

Pressure for Assorted Test Coals ....................... 49

6. Solids Analysis from First Side-Stream Test Series,

Test Runs 82 to 84

7. Contaminant Level in Once-Through Wash, Water

Operating with Illinois No. 6 Coal -- Test Runs 82 and $83 \ldots \ldots . \ldots 5$

8. Measured Emissions in Gas Turbine Simulator Combustor

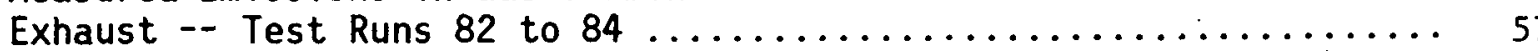

9. Gasification Data, Statistical Analysis of Six Sample Periods, Pittsburgh No. 8 - Arkwright Coal -- Test Run 87 


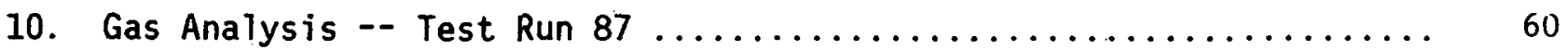

11. Analysis of Recycle and Decanter Liquor -- Test Run $87 \ldots \ldots \ldots \ldots .61$

12. Typical Sample Analysis from the Third Side-Stream Test

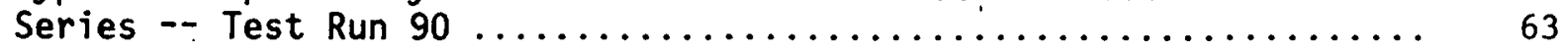

13. Humidifier Performance Comparison of Predicted Versus

Actual Moisture Content of Gas -- Test Run $96 \ldots \ldots \ldots \ldots \ldots \ldots .67$

14. Producer Gas Composition -- Test Runs 95 and $96 \ldots \ldots \ldots \ldots \ldots . . \ldots . \ldots . \ldots$

15. Size Distribution of Cyclone Dust -- Test Run $96 \ldots \ldots \ldots \ldots \ldots . . \ldots 1$

16. Temperature-Viscosity Profile for Recovered Tar -- Test Run $90 \ldots \ldots \quad 73$

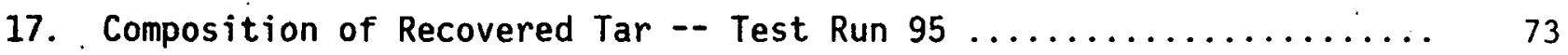

18. Tar and 0 il Samples Taken During Test Run $95 \ldots \ldots \ldots \ldots \ldots \ldots . \ldots . \ldots . \ldots$

19. Tar and 0 il Samples Taken During Test Run $96 \ldots \ldots \ldots \ldots \ldots \ldots . . \ldots$

20. Boiling Point Range of Tar and 0il Samples from Test Run $96 \ldots \ldots \ldots .76$

21. Liquor Samples Taken During Test Run $95 \ldots \ldots \ldots \ldots \ldots \ldots \ldots \ldots \ldots$

22. Particle Size Distribution of Dust Samples Throughout

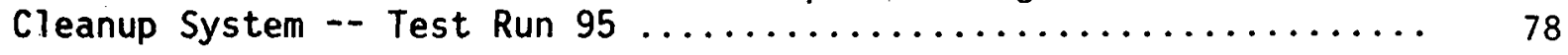

23. Preliminary Performance Summary of the Stretford Sulfur

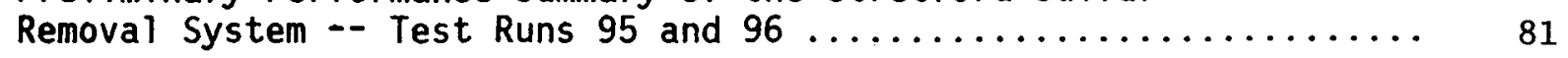

24. Representative Gas Cleanup System Performance --

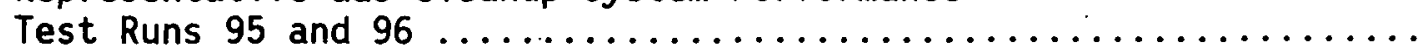

25. Elemental Analysis, Heat Content, Ash Fusion Temperature, and

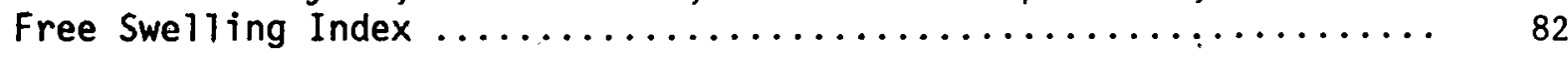

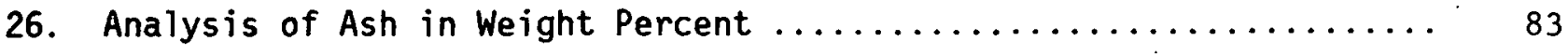

27. Major Gas Analyses by On-Line Gas Chromatograph in

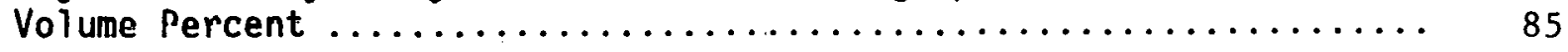

28. Cyclone Dust, Sampling Point SG-Size Distribution -- Cumulative

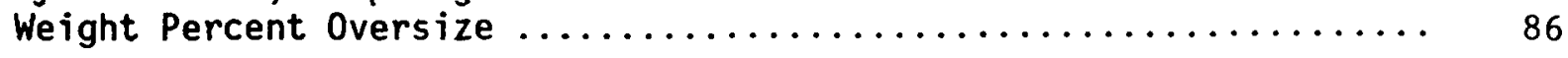

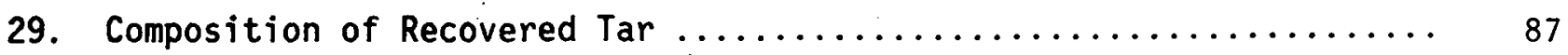




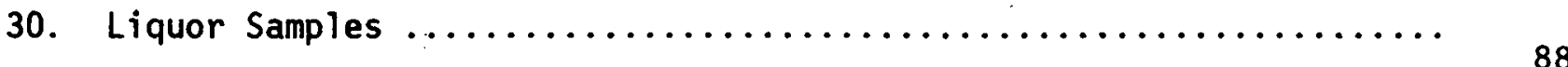

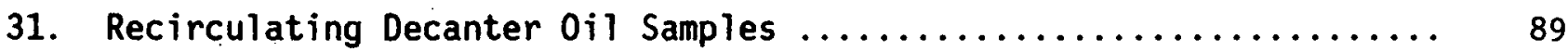

32. Boiling Point Range of 0il Samples from Recirculating Decanter .... 89

33. Levelized Gas Analysis Used for Material Balance Calculation ....... 93

34. Gas Quality Measured Entering Sulfur Removal System --

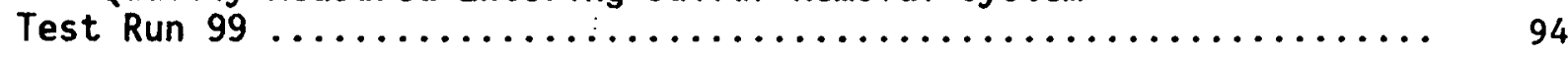

35. Mass Loading of Tars and Water at Cyclone Outlet -- Test Run 99 .... 93

36. Summary of Gasifier Sampling Points $\ldots \ldots \ldots \ldots \ldots \ldots \ldots \ldots \ldots . . \ldots \ldots$

37. Summary Table of Analytical Activities for METC Gasifier ......... 100

38. Workplace Health Activities .......................... 103

39. Summary of Process Condensate Characterization and Normalized Pollutant Production ........................... 104

40. Contaminant Levels in the METC Fixed-Bed Gasifier Product Gas ..... 106

41. Description of the Products of Combustion -- Corrosion/ Erosion Test Facility ................................... 117

42. Test Specimen Material and Vendors -- Corrosion/

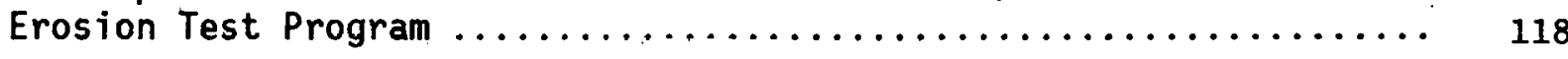




\subsection{SUMMARY \\ 1.1 OVERVIEW}

In 1963, an options analysis by the forerunner to the U.S. Department of Energy (DOE) Morgantown Energy Technology Center (METC) indicated that fixedbed gasification of coal could be a promising technology for utilizing U.S. coals. Evaluation of existing technologies indicated a clear need for the development of usefur generic fixed-bed technology and its applicability to U.S. coal feedstocks and utilization patterns (Synthetic Natural Gas (SNG), combined cycle).

In 1968, testing commenced on a one-ton-per-hour, pressurized fixed-bed coal gasifier in Morgantown. Since then, system development and test strategy have developed in four phases:

\begin{tabular}{|c|c|c|}
\hline Phase & Period & Description \\
\hline I & $1967-1974$ & $\begin{array}{l}\text { Gasifier shakedown and tests on U.S. } \\
\text { coals. }\end{array}$ \\
\hline II & $1975-1978$ & $\begin{array}{l}\text { Additional gasifier tests with a side- } \\
\text { stream cleanup system to define the } \\
\text { potential characteristics of a novel gas } \\
\text { cleanup system, in anticipation of the } \\
\text { need for enhanced environmental controls. }\end{array}$ \\
\hline 111 & $1978-1979$ & $\begin{array}{l}\text { Mechanical shakedown tests of full-flow } \\
\text { novel gas cleanup system developments } \\
\text { and selected gasifier tests. }\end{array}$ \\
\hline IV & $1980-1982$ & $\begin{array}{l}\text { Environmental characterization, partial } \\
\text { characterization of the full-flow } \\
\text { cleanup system and stretford sulfur } \\
\text { removal system debugging. }\end{array}$ \\
\hline
\end{tabular}

METC expanded the facility to evaluate and develop environmentally sound fuel gas cleaning processes and fuel gas utilization systems (e.g., combined cycles, fuel cells, SNG). METC initiated this activity by first developing and testing a sub-scale gas processing train. Successful operation (Phase II) led to the construction and operation of a full-flow gas cleaning system in 1979. A unique, pressurized Holmes-Stretford desulfurization unit was integrated into the cleanup system in 1980. This fully integrated gasification/ gas cleaning system has been used to provide clean, low-Btu (British Thermal Units) gas to a high-temperature, gas turbine material test facility for the evaluation of erosion and corrosion of advanced, ceramic gas turbine materials by actual coal-derived fuel gas combustion products. A simple schematic in Figure 1 shows the current configuration of the system and describes individual unit operations.

The METC fixed-bed gasification program is well integrated within DOE's fixedbed gasification research and development program, providing DOE with the broad capability of addressing alternative and advanced gasification and cleanup technologies. The overall program also includes the University of North 


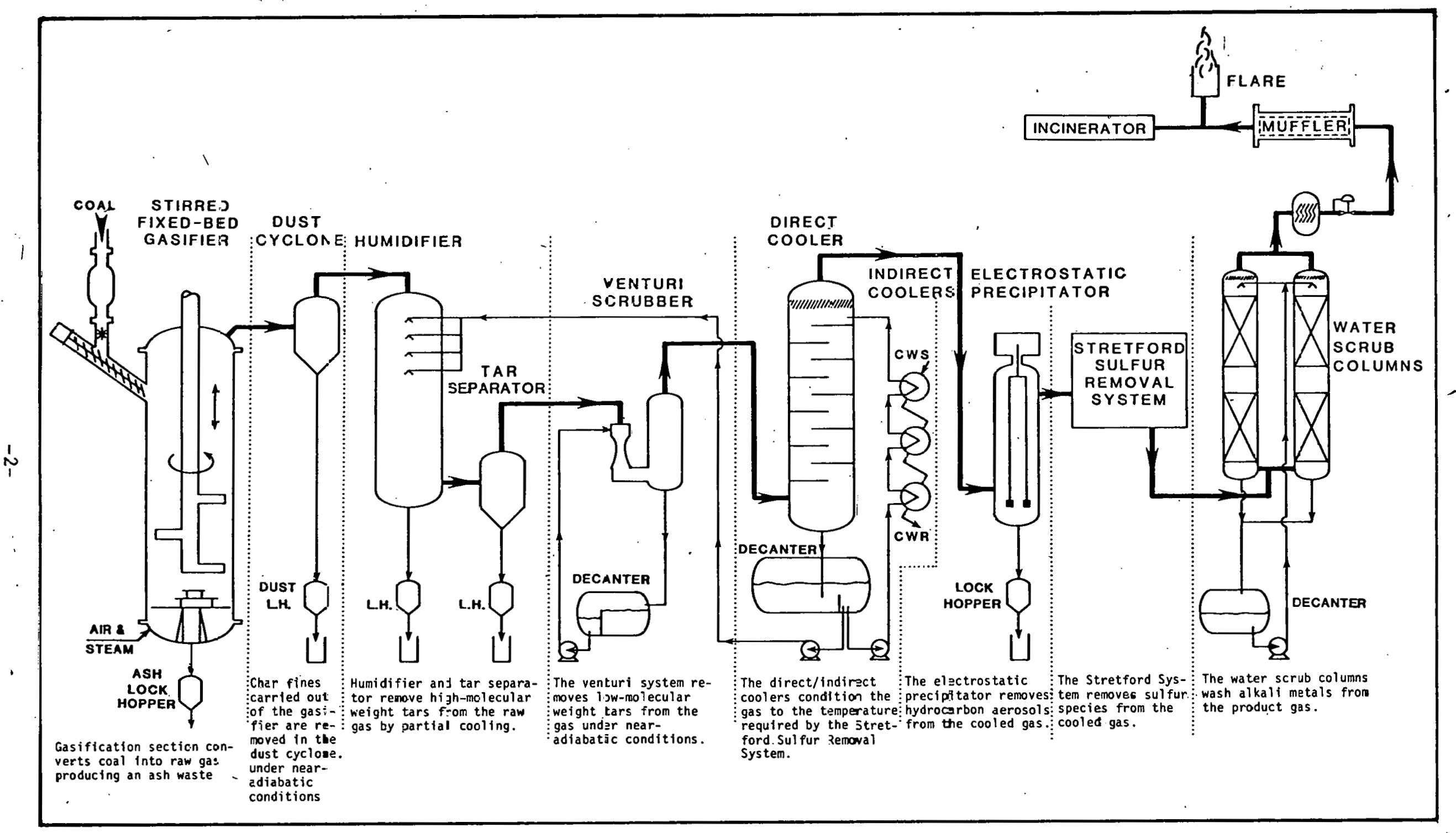

FIGURE 1: METC FIXED-BED GASIFIER AND FULL-FLOW CLEANUP SYSTEM PROCESS FLOW DIAGRAM 
Dakota Energy Research Center (UNDERC, formerly Grand Forks Energy Technology Center) process development unit, the General Electric (GE) gasification system, and the Mining and Industrial Fuel Gas Group (MIFGA) program. The MIFGA program utilizes a 6.5-foot inside diameter Wellman Galusha atmospheric pressure gasifier at Minneapolis/St. Paul, Minnesota, to test a variety of coal fuels and to evaluate the combustion characteristics of the produced low-Btu gas. A tar removal system has recently been installed for use in testing a small skid-mounted Stretford desulfurization unit.

UNDERC is investigating the advanced slagging mode gasifier which offer potential for significantly increasing capacity and reducing steam requirements, both of which improve economics. It al so supports integrated wastewater. treatability research. The GE gasifier is somewhat similar to METC's except that it is completely refractory lined and is uncooled. GE's gas cleanup configuration follows the more conventional deluge gas-washing approach in contrast to METC's "dry tar" removal concept. GE and METC are experimenting with collecting and reinjecting coal fines and recovered tars into the gasifier to improve the process. METC is taking the lead in oxygen-blown operation of the dry ash fixed-bed gasifier along with a multi-faceted gasifier and cleanup system development program.

Whenever possible, projects related to the METC fixed-bed gasification program are integrated with other government organizations such as: the Environmental Protection Agency (EPA) and the National Institute of Occupational Safety and Health (NIOSH); Oak Ridge, Argonne, Sandia and Brookhaven National Laboratories; and industry-sponsored organizations such as the Electric Power Research Institute (EPRI) and the Gas Research Institute (GRI).

A balanced approach has been adopted at METC towards extracting research and development (R\&D) information from the test facility. In keeping with its lead role in surface gasification, METC has taken a systems analysis approach in defining the data needs and tests for the METC fixed-bed gasification system. Therefore, research is conducted not only on the gasifier but also in the related areas of novel gas cleanup processes, product gas utilization, and environmental control; areas where improved efficiencies through new R\&D could lead to enhancement in the overall feasibility of large coal conversion plants. Fixed-bed gasification spinoffs from such research and development activities can al so help other gasification technologies. An overview of the program with its key components is shown in Figure 2. A detailed description of the METC facility is included in Section 3.0. Section 5.0 sumarizes the results of the 100 test runs conducted from 1967 through 1982 . Key complementary programs which operate in conjunction with the METC facility are described in Section 4.0. The principal direct recipients of information from the METC Fixed-Bed Gasification Program are the METC Gasification Technology Data Base, R\&D divisions of other government agencies, and the private sector.

\subsection{PROGRAM ACCOMPLISHMENTS}

Each phase of the gasification program has drawn upon the lessons learned from the tests which preceded it. Table 1 highlights the major accomplishments for each phase of the gasification program and indicates the "building block" development of METC'S Full-Flow Cleanup System (FFCUS). Phase I gasifier system 


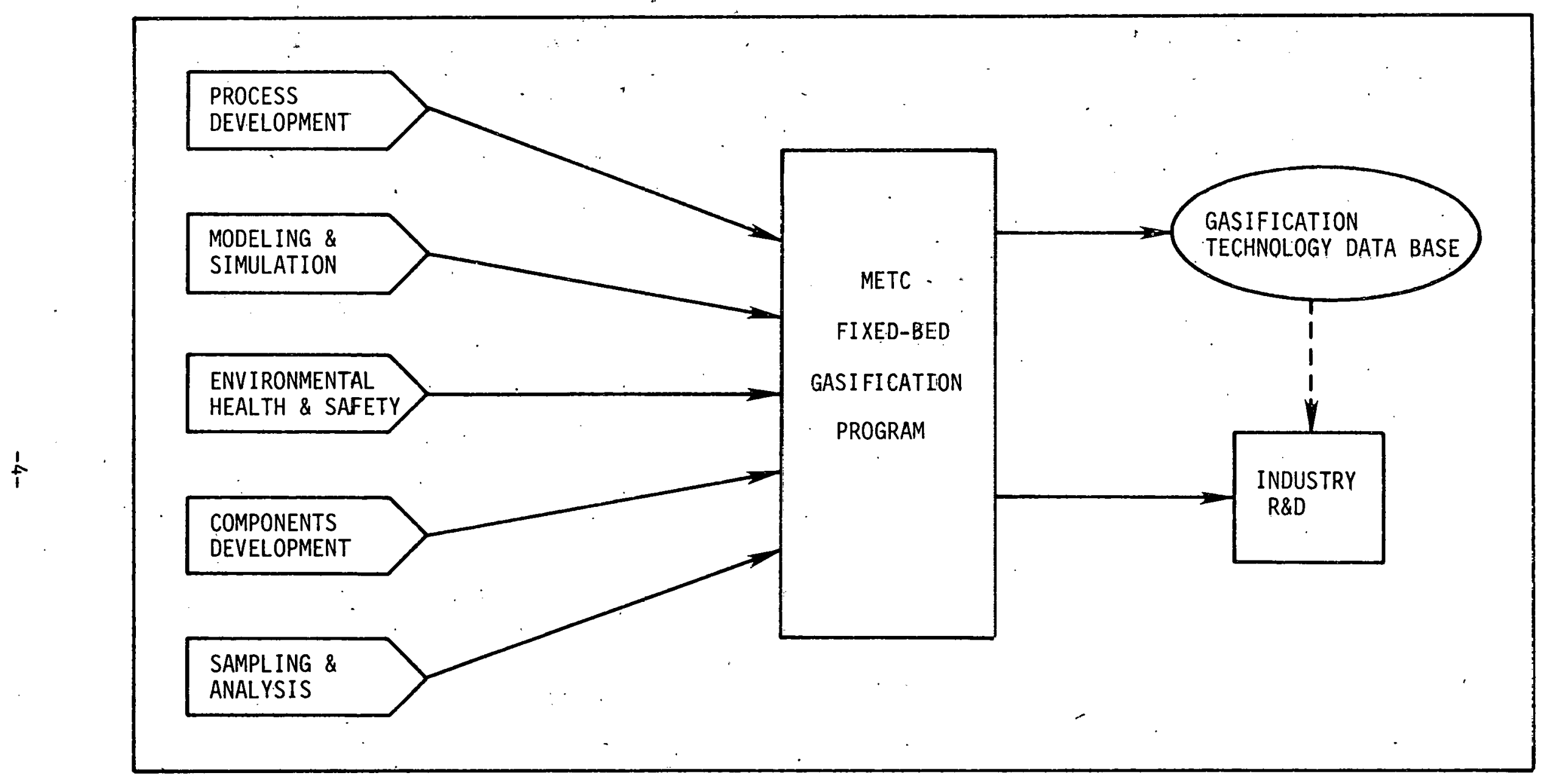

FIGURE 2. METC FIXED-BED PROGRAM OVERVIEW 


\begin{tabular}{l}
1967 Phase I 1974 \\
\hline Runs 1- 82 \\
- Tested gasification \\
of 15 types of coal \\
of varying coal sizes \\
- Tested gasification \\
at pressures from \\
atmospheric to \\
300 psig \\
- Developed hydraulic \\
grate drive \\
- Developed improved \\
coal feeding \\
techniques \\
- Developed nuciear \\
level detector.
\end{tabular}

$\frac{1974 \text { Phase II } 1978}{\text { Runs } 83-90}$

- Tested various con-
figurations to develop optimum cleanup system

- Demonstrated humidifi. cation "dry-tar"

- Tested erosion/ corrosion of gas materials

- Characterized gasification by-product

- Developed aerosol sampling techniques

Runs $91-94$

- Tested full-flow dust cyclone

- Improved design of coal feed system

- Installed continuous monitoring of erosion

Developed stirrermounted thermocouples.

- Tested alternative humidifier spray nozzles

- Tested tar separator technique - Hydraulic stirrer

- Successfully measured aerosols in gas strean

- Developed on-line alkali metals monitor

- Tested Venturi scrubbe removal of low molecular weight tars
from gas

- Installed ADACS
$1980 \quad$ Phase IV 1982 Runs 95 - 100

Tested full-f.10w cleanup system

- Tested Stretford sulfur removal system; performed improvements

- Provided 1000 hours of gas supply to corrosion/erosion test facility

- Demonstrated coal fines utilization by feeding coal
briquettes

- Characterized trace metal levels in

- Characterized major/ process streams

- Performed health and safety analysis of

- Characterized plant emissions

- Performed simulations using computer models

- Updated control sy'stems

- Improved component

- Documented METC program test results

$1983 \quad$ Goals $\quad 1984$

$$
\text { Runs } 101 \text { - } 104
$$

Process Development

Operate oxygen blown gasifier and cleanup system using lignite and other coals

- Complete characterization and long-term

- Characterize performance at varying system throughputs

- Characterize fines recycle and briquette gasification using air

- Perform process dynamics and control studies for gasifier and FFCUS

Environmental Development

Environmental characterization of

- Environmental characterization using briquettes

- Perform environmental systems analysis

- Perform comparative analysis for dry and deluge quenches

- Complete high pressure, high temperature desulfurization tests using zinc oxide

Sampling and Analysis efine precision of advanced analytical laboratory instruments

- Develop and test new analytical techniques

Components Development Complete testing of Peerless Separator and $E S$

- Complete development of hardened stirrer

Modeling and Simulation

Perform process simulation of oxygenblown operations

Improve process models for direct cooler. Stretford system and humidifier

- Perform dynamic similation and validate with transient dato

- Test scenarios for alternative operation 
testing began in Morgantown in 1967 and ended as a separate program in 1976 when development of the cleanup system began. Over this period, 81 test series were run on 15 different coals and coal mixtures ranging in size from 2-inch to run-of-mine.

This first phase of testing demonstrated the operability of the gasifier, and its capability for continuous operation at pressure on a wide spectrum of coals, including highly-caking coals. The coals tested ranged from anthracite to lignite. The only coal which created operating problems was North Dakota lignite which, as anticipated, suffered severe decrepitation and resulted in high dust loadings in the product gas. During this period, a fixed backpressure orifice was utilized and consequently, pressure and flow were not independent. In the present setup, a control valve permits control of backpressure independent of gas flow. This provides closer control of bedflow velocities and attendant reduction of dust carryover.

An initial performance data base was established for near-atmospheric and pressure operation. Tar- and dust-free gas heating values were generally in the range of 130 to 150 British thermal units per Standard Cubic Foot (Btu/SCF). Calculated cold gas efficiencies were generally in the range of 60 to 80 percent. (Uncertainty in this value was a result of the inability to accurately measure product gas flows directly at that time, because the gas could not be cleaned to a level consistent with reliable instrument accuracy. This. capability is now developed and is an example of a means for upgrading the data base).

Improving the reliability of the gasifier system which includes auxiliaries such as coal receiving, handling, and lockhopper feeding, ash letdown and disposal, air and steam supply systems, and fuel gas incineration, has been a major concern and effort. Many design modifications have been engineered and successfully demonstrated. Some of these design improvements are listed below.

- Development of an hydraulic grate drive systenl for controlled ash removal from the gasifier. This feature facilitated the maintenance of an established ash level, critical to process stability.

- Development of an improved coal feeding system featuring metering valves and screw feeders, which gave a positive means of transporting batch-weighed coal into the gasifier at a constant rate. Consistent output gas properties are contingent on constant uniform coal feeding. The screw feeders al so permit use of coal fines since they eliminate coal hangup and the inevitable resulting blockages due to tar formation.

- Defelopment of a nuclear detector system for measuring bed depth and void formations. This non-intrusive capability provided the information needed to maintain stable bed levels, critical to a consistent gasification process.

- Development of valid sampling and analysis procedures that function in a complex and/or harsh environment. 
In Phase II testing and prior to embarking upon a program for construction and evaluation of a full-scale gas cleanup train, METC fabricated and tested a side-stream cleanup system capable of processing 20 percent of the gasifier output gas. This testing started in June 1976 and was completed in 1978. During this phase, nine series of tests were completed in more than 750 hours of operation. In addition, a preliminary gas turbine materials erosion/corrosion test on cleaned low-Btu gas was performed at METC in cooperation with the General Electric Company. The combustion and turbine simulators were operated on cleaned low-Btu gas for a total of 144 hours. While encouraging, the short-term results were not conclusive and it was determined that longer-term testing was required.

Various gas cleanup configurations were tested and evaluated for their effectiveness in. cleaning high-volatile bituminous coal product gas streams to suitable levels for end users. Product gas, byproducts, and effluent data were characterized for the various configurations tested. Based on this information, component designs and an initial configuration for the full-flow gas cleanup train were selected. A key accomplishment in Phase II testing was the demonstration of the feasibility of the "dry tar" removal concept. This permitted the condensation and removal of the high-molecular-weight tars without the need for costly water/tar separation equipment that is associated with commercial deluge-quench systems.

Phase III testing, evaluation of the FFCUS, began in September 1978. Initially, only the upstream cleanup train components, i.e., the dust cyclone, humidifier, and tar separator were utilized. Once these units were evaluated and the necessary modifications were made to ensure satisfactory operation, the remaining downstream components were sequentially added. Accomplishments in the first three test series in this phase included:

- The redesigned screw feeder bearing and seal assemblies were proven to be successful and eliminated one of the major causes for run interruptions.

- The type and sizing of single-phase humidifier nozzles were established for full-flow conditions. These nozzles were arranged in a multiple array, using filtered recycled sour water and cascade controlled on the basis of humidifier outlet gas temperature. Two-phase nozzles, using nitrogen or eventually using recompressed product gas as the propellant, were economically and performance-wise inferior to the single-phase type, particularly at higher pressures. A technically and economically viable gas quenching operation was crucial to the dry-tar feature for removing high-molecular-weight tars and to the ensuing continued development of the sequential gas cleanup system.

- A new stirrer drive was installed and tested. It provided controlled, trouble-free operation. This added substantially to system reliability and enhanced gas properties through improved bed-density control. 
- A cyclone-type tar separator was selected as the most efficient means of removing the high-molecular-weight tars exiting the humidifier. A number of alternative schemes were tested (including several baffle arrays, orifice-impact plate arrangements, and a settling chamber), but proved less desirable.

In Phase IV, the Stretford Sulfur Removal System was added to the FFCUS, giving METC the potential to produce relatively large quantities of clean, nearly sulfur-free, fuel gas. System testing is presently in this phase. The current cleanup system configuration, in sequential order, consists of a cyclone particulate separator, humidifier featuring single-phase spray atomization nozzles, a cyclone-type tar separator, a venturi scrubber, a direct contact cooler, an electrostatic precipitator (ESP), a Stretford system for sulfur removal, and a final water scrub column. The ESP was relocated from upstream to downstream of the direct cooler in the hope that it would operate more effectively in this less hostile environment and reduce hydrocarbon levels entering the desulfurizer. All components have been developed and tested through an initial phase and have been found to perform satisfactorily, although some mechanical refinement of the ESP and the Stretford systell dre in progress.

During Phase IV, highly-caking Pittsburgh No. 8 coal has been processed to produce an ultra-clean, low-sulfur fuel gas of approximately $170 \mathrm{Btu} / \mathrm{SCF}$. Six test series have been run to date for a total operating time exceeding 8000 hours. Test Run 98, conducted in July and August 1981, logged 733 hours of operation with an availability of 93 percent. Accomplishments during this phase included:

- The Corrosion/Erosion Test Facility was supplied with fuel gas for 1000 hours in three test phases. This was in support of high temperature ( 2600 degrees Fahrenheit or ${ }^{\circ} \mathrm{F}$ ) dynamic and static screening tests of candidate advanced ceramic turbine materials.

- Tar/fines utilization capability was successfully demonstrated in a test using briquettes made from coal fines and high-molecular-weight tars extracted by the cleanup system. Ine quanticy of extracted lars used in this test was shown to be adequate to bind the 50 percent of coal fines (<1/4-inch size) associated with run-of-mine coal. This is important to users unable to gasify coal fines. More definitive follow-on system characterization tests are presentiy scheduled.

- System automation activities have favorably impacted economic and operational factors. Manpower requirements have been halved while data quality, resulting from more stable operating conditions, has dramatically improved. The operators have been relieved of numerous mundane, repetitive dutles and consequently can more effectively address the basic process parameters and test goals. Automated control functions include coal handling, bed height, system pressure, process temperatures, air-steam ratio, ash level/removal, data acquisition and processing. 
- Environmental health and safety (EH\&S) research and results are being compiled into a detailed report. Substantial work has been accomplished in characterizing process and effluent streams to help assess potential hazards to personnel or the environment. Findings and accomplishments in these areas include:

- Preliminary pollutant production characteristics have been developed based on comprehensive environmental characterization during Runs 97 and 98.

- The workplace air space does not constitute an extraordinary environmental hazard when reasonable guidelines are followed for operating procedures, protective attire, and selective use of respirators.

- Ash properties from the fixed-bed gasifier meet Resource Conservation and Recovery Act (RCRA) guidelines for disposal through landfill techniques. This resolves major logistical and environmental concerns for large plants generating similar ash.

- Substantial wastewater analytical data have been generated in support of external wastewater treatment programs.

- Modeling activities have been extensively supported through cooperative system operations and the resulting data acquisition. The models are essential in characterizing systems and components for economical and technical purposes. Predictions of performance, through extending actual performance data as well as scaling parameters in future plants, are important elements of the gasification data base. Although this activity is separately reported, the associated areas addressed and accomplished include:

- The models of the gasifier by Wen, the humidifier by Physical Sciences Inc., and the Stretford system by METC have been used to develop an integrated Advanced System for Process Engineering (ASPEN) simulation of the fixed-bed gasifier and cleanup system.

- The Wen gasifier model has been upgraded and used to predict operating parameters for oxygen-blown operation of the METC fixedbed gasifier.

System reliability and operability have been demonstrated during more than 2,300 hours of Phase IV testing. The following areas of accomplishment contributed significantly to improved operations.

- A slotted, Bosh (wear) ring design has been successfully developed and tested that does not suffer any of the thermally induced warpages experienced frequently in the old design. Warpage of this ring, located in the grate area, results in channeling of inlet air. This channeling results in hot spots, uncontrollable fire zone size and location, thermal damage to grate area components, and eventual shutdown for repairs. 
- Surface hardening technology has been successfully applied to components suffering severe abrasion and erosion damage. A diffusion coating of boron carbide processed to a depth of approximately .020 inch has dramatically extended the useful life of the tar separator cyclone. Development testing is still ongoing with extremely encouraging results. Stirrer arms have been hardened using a 1/8-inch thick weld overlay coat of Titanium Carbide/Stellite 6 and a subsequent diffusion coat of boron carbide. The stirrer arm configuration has al so been redesigned to reduce torque requirements, improve bed agitation, and reduce manufacturing costs. Although long-term evaluation is ongoing, these design changes, coupled with surface hardening, have virtually eliminated concerns about stirrer abrasion.

Table 2 summarizes general run parameters and accomplishments achieved during Phases III and IV of the test program.

\subsection{GOALS FOR FISCAL YEARS 1983 AND 1984}

The desired near-term goals of the fixed-bed gasification program can be broadly distributed among the major program components shown in Figure 1. These goals, based on at least four additional test runs, are enumerated in five separate categories (summarized in the last column of Table 1).

A primary objective of these test runs will be to generate data from the gasifier and cleanup system in the oxygen-blown mode. This will be performed in the following sequence: first, test the functional capability of the new hardware; second, conduct tests comparing the gasifier performance with oxygen to the many tests conducted using air and Pittsburgh seam coals; and last, conduct complete characterization of the gasification of North Dakota lignites. R\&D activities will be conducted in the areas of: process design; environmental health and safety; computer simulation; analytical sampling techniques and on-line analysis; and process components development.

An environmental characterization will be performed to resolve several issues related to dry-bottom fixed-bed gasification systems such as the Great plains Gasitication Project. Comprenensive information will also be ublained to compare the environmental differences between air-and oxygen-blown operation. Light and heavy hydrocarbon liquids will be sampled (especially during lignite runs) for comprehensive biological analysis. In addition, the Stretford Desulfurization Process will be characterized from the standpoints of pollutant capture, liquor chemistry, and development of process design criteria. Development of advanced analytical techniques will continue, partly in conjunction with the environmental R\&U effort. Furthermore, this effort will include the continued testing of laser-induced, on-line concentration measurement techniques. Computer models will be used to assist test planning and, in turn, test data will al so be used for model verification. These include models of fixed-bed gasifiers (dry-bottom) using lignite coal, the Stretford desulfurization unit, rigorous models of the METC direct cooler and transient/dynamic models of the gasifier. METC's Test-Data Data-Base (part of the METC Gasification Technology Data Base Projectl will also be used to store and analyze the data. Finaliy, the performance of new and/or improved hardware components will be evaluated in upcoming test runs. Several of these (e.g., the gasifier stirrer) will be designed with hardened surfaces to study resulting increase in operating 1 ife. 
TABLE 2. METC STIRRED F́IXED-BED GASIFIER AND FULL-FLON CLEANUP SYSTEM RUN SUMMARY

\begin{tabular}{|c|c|c|c|c|c|c|c|c|c|}
\hline & RUM NO. & CONL TYPE & $\begin{array}{l}\text { PRESSURE } \\
\text { (PSIG) }\end{array}$ & $\begin{array}{l}\text { ELASPSED } \\
\text { (HOURS) }\end{array}$ & TIME & GASIF IER MOD IF ICATIONS & CLEANUP SYSTEM MODIF ICAT IONS & $\begin{array}{l}\text { HOLMES-STRETFORD } \\
\text { DESULFURIZATION }\end{array}$ & COMANTS \\
\hline & $91 / 92$ & $\begin{array}{l}\text { Plttsburgh } \\
\text { (A } 8 \text { (Arkwright) }\end{array}$ & & 91 & - & & $\begin{array}{l}\text { Tested system through tar } \\
\text { separation; high-efficiency } \\
\text { dust cycione failed rapldiy }\end{array}$ & . & $\begin{array}{l}\text { Tested various dust } \\
\text { cyclones and tar } \\
\text { separators }\end{array}$ \\
\hline$\Xi$ & 93 & $"$ & 118 & 304 & & r & Tested nozzles in humidifier & & " \\
\hline 竞 & 94 & $"$ & 131 & 206 & & Hydraulic Stirrer Drive & $\begin{array}{l}\text { Venturi scrubber added, short } \\
\text { humidifier, al ternate tar } \\
\text { separators, sidestream } \\
\text { cos conversion }\end{array}$ & & $\begin{array}{l}\text { Upper limit of } 60 \mathrm{MSCFH} \\
\text { in humidifier; alkali } \\
\text { level in gas measured } \\
\text { by "Ames" meter }\end{array}$ \\
\hline & 95 & " & 211 & 608 & & Single-arm stirrer & $\begin{array}{l}\text { Direct cooler added, } \\
\text { enlarged humidifier, } \\
\text { single-phase nozzles }\end{array}$ & $\begin{array}{l}\text { Startup, system } \\
\text { upsets }\end{array}$ & $\begin{array}{l}\text { Humidifier and nozzles } \\
\text { acceptable; HSOU } \\
\text { reduced } \mathrm{H}_{2} S \text { to } 10 \mathrm{ppm}\end{array}$ \\
\hline & 96 & " & 200 & 170 & & $\begin{array}{l}\text { Instrumented stirrer } \\
\text { excellent for bed } \\
\text { control }\end{array}$ & $\begin{array}{l}\text { Piping changes to el iminate } \\
\text { upsets, ESP startup }\end{array}$ & $\begin{array}{l}\text { Startup mode, } \\
\text { operational } \\
\text { problems }\end{array}$ & $\begin{array}{l}\text { First phase of ceramic } \\
\text { materials exposure } \\
\text { completed; HSOU } \\
\text { reduced } \mathrm{H}_{2} \mathrm{~S} \text { to } 10 \mathrm{ppm}\end{array}$ \\
\hline & 97 & $"$ & 140 & 383 & & Automatic coal feed & $\begin{array}{l}\text { Multi-clone tar separator, } \\
\text { fume vent system }\end{array}$ & $\begin{array}{l}\text { Startup mode, } \\
\text { operational } \\
\text { problems }\end{array}$ & $\begin{array}{l}\text { HSDU sul fur removal } \\
\text { acceptabie; effluents/ } \\
\text { industrial hygiene } \\
\text { data, wastewater } \\
\text { collected }\end{array}$ \\
\hline $\begin{array}{l}\geq \\
\&\end{array}$ & 98 & $\begin{array}{l}\text { Kitanning } \\
\text { (low Sulfur) }\end{array}$ & 100 & 733 & & New stirrer design & Continued ESP tests & Not operated & $\begin{array}{l}\text { Effluents data and } \\
\text { wastewater collected; } \\
\text { EPA/radian sampling }\end{array}$ \\
\hline 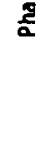 & 99 & Pittsburgh & $160-200$ & 300 & & $\begin{array}{l}\text { Tested new stirrer } \\
\text { coatings, automatic } \\
\text { ash removal }\end{array}$ & $\begin{array}{l}\text { ESP relocated downstream } \\
\text { of direct cooler }\end{array}$ & $\begin{array}{l}\text { Performance testing } \\
\text { gave } \mathrm{H} \text { S removal to } \\
400 \cdot \mathrm{pph} \text { with accep- } \\
\text { table carryover: } \\
\text { sul fur produced }\end{array}$ & $\begin{array}{l}\text { Gas to HSDU accep- } \\
\text { table; effluents/ } \\
\text { industrial hygiene } \\
\text { data collected }\end{array}$ \\
\hline & 100 & " & 150 & 96 & & $\begin{array}{l}\text { Tested automatic coal } \\
\text { feed controlled by } \\
\text { gasifier bed level; } \\
\text { tested gasification of } \\
\text { briquettes }\end{array}$ & $\begin{array}{l}\text { Added droplet separators } \\
\text { in Stret ford piping } \\
\text {, }\end{array}$ & $\begin{array}{l}\text { Tested enlarged sieve } \\
\text { tray holes in } \\
\text { absorber; near design } \\
\text { sulfur removal } \\
\text { achieved at design } \\
\text { liquor flows }\end{array}$ & $\begin{array}{l}\text { Stirrer shaft seal } \\
\text { excessive leakage }\end{array}$ \\
\hline
\end{tabular}


These tests have been integrated into a comprehensive plan. Each research project will be conducted in a staged manner to allow the experience gained from each test to direct the parameters of study for the next test run. Figure 3 presents the test schedule for Test Run 101, next in the current series of tests. The elements of the test schedule are:

- Anthracite coal will be used for initial "Light-off" to warm up the system and avoid condensation of tars in the cold equipment.

- Characterization of the Stretford Tray hydraulics will be conducted at varying gas velocities.

- Arkwright, a locally available Pittsburgh \#8 seam coal, will be used for stabilization of the system and for oxygen gasification check-out tests.

- Briquettes made of crushed coal and a binder of gasifier tar will be tested to determine the fate of the tars when recycled and how well briquettes hold up inside the gasifier.

- Blacksville coal (used to manufacture the briquettes) will be tested to quantify differences between the two feedstocks.

- Transient analysis studies will be conducted to provide dynamic behavior data of the system for validation of computer simulation programs.

- Tests will be conducted to determine the dynamic effects of alternate stirrer operating modes on gas quality.

- Tests will be conducted to verify the efficiency of the ESP at hydrocarbon mist removal.

- The Peerless Separator, a commercially-manufactured tar separator, will be tested to determine the effectiveness of a multicione device for separating tars.

\subsection{INTRODUS.TION}

The purpose of this report is to summarize the development of the METC highpressure fixed-bed gasifier and cleanup system. This report documents the system's evolution since its inception through the end of 1982, and presents data representative of its performance. For complete information concerning any given test run, inquiries should be addressed to METC. Reports covering major activities of this program are planned for the near future. A synopsis of major program accomplishments was included in Section 1.0 with the highlights of testing planned for 1983 and early 1984. Section 2.0 details the background and program objectives of the fixed-bed gasifier and cleanup system. A detailed description of the function and operation of each component of the facility appears in Section 3.0. Section 4.0 describes many of the complementary programs implemented in conjunction with the system. A discussion of the results of system testing, including complementary programs, 


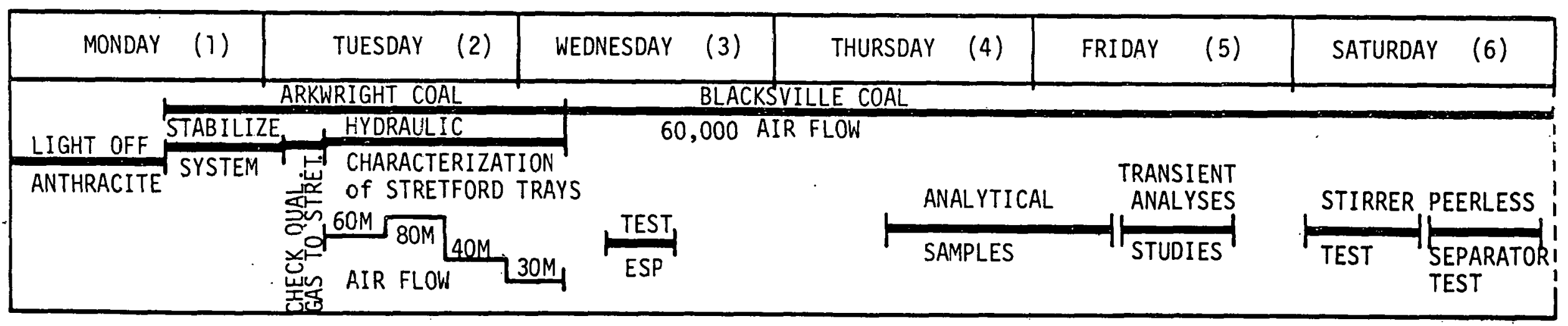

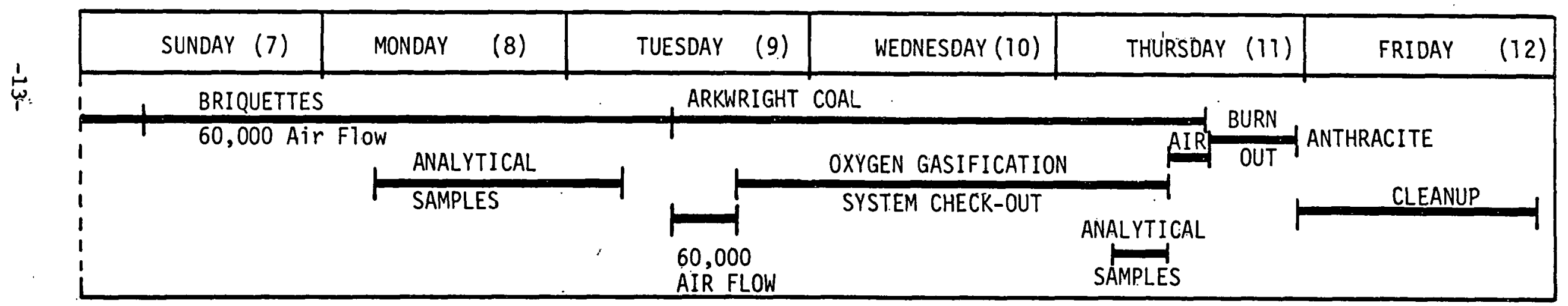

FIGURE 3. METC FIXED-BED GASIFICATION PLANT TEST SCHEDULE FOR RUN 101 
is contained in section 5.0. Section 6.0 is a glossary of acronyms and abbreviations, Section 7.0 is a list of reference documents, and Appendix $A$ gives dates, coal tested, and operational hours for each of the 100 test runs conducted through 1982.

\subsection{BACKGROUND}

The low-pressure gas producer concept for coal gasification is a proven method of producing a usable gas fuel. Numerous producer plants were operational in the United States as recently as the 1950's. However, the completion of interstate natural gas pipelines in the 1950 's introduced clean, low-cost natural gas to wide areas of the nation and doomed the gas producer industry. In fact, the availability of lower-cost natural gas is still the major impediment to a revival of the low- and medium-Btu gasification industry. The recent rapid escalation in natural gas prices and uncertainties in the long-term availability. of natural gas are significantly changing this situation. However, a favorable economic climate vis-a-vis natural gas prices will not in itself guarantee a swift changeover to coal gasification by American industry. A secure and reliable fuel source is vital to industry, and there are still many uncertainties associated with coal gasification. These uncertainties stem from potential problems with present-day U.S. environmental requirements, the lack of data on large-scale gasification plant performance and reliability, and the lack of adequate and pertinent operational experience.

Recognizing that industry's concerns could seriously delay the implementation of this technology, DOE has embarked on programs that sponsor the development of improved technology to a proof-of-concept stage and the development of a data base on the full range of coals and environmental effluents. In 1967 a coal gasification test unit was installed in Morgantown and the capabilities were developed to generate data over a wide range of operating conditions and coal feeds. The METC gasification system has been expanded so that it can now gasify the entire spectrum of U. S. coals from lignite to anthracite, and can clean and desulfurize the resulting fuel gas so that it is available for testing various applications. This unique test facility has made significant contributions to the publicly-available fixed-bed gasification data base in the United States.

This report presents the objectives and accomplishments of the METC fixed-bed gasification program, describes the evolution and present physical configuration of the gasification and gas cleanup system, discusses the results of the various test phases of the program, and describes complementary projects in the areas of process modeling and environmental characterization projects. It al so outlines METC's goals and future plans for this facility.

\subsection{GASIFICATION PROGRAM OBJECTIVES}

Fixed-bed gasification represents the most highly developed of all gaslfication technologies. It is potentially the most efficient gasification process, and it presents environmental problems. The major drawbacks of commercial European fixed-bed gasifier technology have probably been the lack of a demonstrated ability to process highly-caking coals, and the inability to clean the product gases so that they can meet end-use and environmental requirements. These problems were recognized at Morgantown when plans were made in 1963 to construct a nominally one-ton-per-hour fixed-bed coal gasifier. The heart of this facility, a 3.5-foot-diameter, pressurized gasifier, is capable of gasifying all ranks of $U$. S. coals, including the highly-caking eastern coals. 
In 1976 METC began construction of a gas cleanup facility in order to evaluate environmental problems associated with fixed-bed coal gasification plants and to develop improved cleanup systems. The construction and preoperational testing of this FFCUS was completed during the fall of 1980; the METC facility can now gasify all U. S. coals and remove particulates, tars, oils, sulfurcontaining gases, and alkali metals from the resulting fuel gas streams.

Since installation of METC's gasifier in 19.67, gasifier operation has been tested and evaluated on all major ranks of $U$. S. coals. The purposes of the initial testing phase were to demonstrate operation at pressure on highlycaking coal; develop a data base on a wide range of $U$. S. coals, and improve the operability and performance of the gasifier and the coal feeding system design. The first phase of the program originally proceeded gradualiy, at a rate consistent with modest funding levels and consistent with the absence of a major drive towards this technology. This situation changed in the mid-70's as the U.S. became aware of its limited oil and natural gas supplies, and began to appreciate the need to safeguard the environment. Cost studies indicated that combined-cycle gas turbine and fuel cell plants powered by coal-derived synthetic fuels could compete economically with conventional power systems. The prospect of greater thermal efficiencies was seen with advanced cycle design. Thus, the stage was set for an increasing interest in gasifier development and an adequate system for cleaning the fuel gas stream.

Gas stream cleanup testing at METC began in June 1976. The purpose of this testing phase was to clean the fuel gas to the low impurity levels required by some of the more advanced power generating systems then under development, and to accomplish this in a manner consistent with concerns over protecting the quality of the environment. In pursuing these goals, novel techniques of gas cleaning which had not been tried in earlier low-pressure gas producers were evaluated. These techniques may not require as extensive a waste water treatment as that needed with existing commercial deluge-quench techniques. These methods provide a more complete separation of coal gasification by products, thus, potentially improving economics. The advanced power system concepts under development include combined-cycle systems which burn cleaned coal-derived fuel gas in gas turbines, and fuel cell combined-cycle power plants which convert fuel gas energy directly into electrical power via electrochemical reactions. Both of these concepts require ultra-clean fuel gas, since even extremely low levels of particulates and alkali metals can cause erosion and corrosion damage to gas turbine blades. Concentrations of sulfur and ammonia gas impurities as low as one part per.million can produce unacceptable degradation in fuel cell power plant output. The improved gas cleaning techniques are also potentially applicable to oxygen-blown (medium-Btu) gasifiers which provide feed gas to synthetic natural gas and liquid fuels plants.

The above technical and environmental issues form the basis for a specific set of objectives for the METC gasification system, which are as follows:

- Develop Technical Data Base - Provide a publicly available data base for industry on a fixed-bed gasifier and gas cleaning system operating on wide ranges of U.S. coals, feed rates, and pressures. Develop and demonstrate reliable gasifier performance for this spectrum of coals including the highly-caking coals. Investigate the effects of operating conditions on system efficiency, component performance, byproducts, and effluents. 
- Test Novel Cleanup System - Develop and demonstrate reliable performance of a novel gas cleaning system that sequentially removes particulates, tars, oils, sulfur-containing gases, and other gas contaminants while producing a clean, environmentally acceptable fuel gas. This process is an alternative to the deluge-quench systems currently used commercially, and has potential economic and environmental advantages.

- Perform EH\&S Safety Research - Address the EH\&S aspects of the fixedbed gasification system. Identify the type and quantity of gaseous and liquid contaminants that may pose hazards to workers or the environment. Quantify worker exposure to hazardous materials and minimize these potential hazards by developing safer effluent handling systems and operational techniques.

- Support Downstream Testing - Provide a source of coal-derived fuel gas for various end-use testing. The sequential cleanup system can provide gas in varying stages of cleanliness up to a turbine-quality fuel. As such, it can support a wide variety of testing including combustion studies; turbine blade materials evaluations for corrosion and erosion, development of control systems and instrumentation, and testing and evaluation of mechanical components and operational procedures.

- Develop and Test New and Improved Sampling and Analytical TechniquesConduct on-line/in-situ characterization of major/minor gas phase species as well as carryover of contaminants, i.e., particulates, hydrocarbons and heavy metals.

- Support and Apply Computer Modeling - Conduct computer-aided modeling and simulation of the fixed-bed gasifier and FFCUS to predict the performance of the facility at varying conditions and with a multiplicity of feed coals. Validate these models through the interpretation of test run data.

The proyram is presentily in Phase IV of the development and evaluation sequence. The phases are somewhat overlapping since the testing of new 1 deas and components in all systems is an ongoing process. The reason for adopting this methodical "building-block" approach was tc maximize the quantity of information and data gathered with respect to the amount of funding invested in the program. For instance, rather than move immediately from gasifier to FFCUS testing, METC chose to develop a small-scale side-stream gas cleanup train. The amount of gas processed in this side-stream cleanup train was approximately one-fifth of the total gas flow stream. This procedure enabled METC to evaluate and test process components and cleanup train arrangements of small size and at relatively low cost before making a commitment to the larger and more expensive process units and configurations. In like manner, the FFCUS had to reach a certain minimum level of gas cleaning performance before the sulfur removal system was added to the gas cleanup train. 


\subsection{GASIFICATION SYSTEM DESLRIPTION}

The current configuration of the METC fixed-bed gasification system has evolved since its inception in 1967 to the current process configuration (see Figure 1 in Section 1 of this report). The following discussion describes the configuration and function of each component of the system as it currently stands and also explains its evolution through the "building-block" phases of the test program.

\subsection{GASIFICATION SYSTEM DESCRIPTION}

Figure 4 shows the plant coal handling and gasifier systems. Coal crushed to less than two inches is delivered by truck, unloaded into a truck unloading hopper, and conveyed via a belt conveyor and a bucket elevator to two enclosed storage silos. The smaller silo has a capacity of 25 tons and is used to store anthracite coal. Anthracite coal is used to start the gasifier since it contains very little volatile matter and avoids fouling the system with tars and oils which might condense on the cold downstream components and piping. The large silo has a storage capacity of 100 tons and stores the normal operating coals. This storage capacity is sufficient to carry the gasifier through a weekend at maximum operation capacity.

Coal feed for the gasifier is discharged from the bottom of the silo onto a belt conveyor. The coal drops onto a weigh cell, the output of which is utilized to record feed rate; the coal is then conveyed by bucket elevator to a dual, pressurized coal feeding system. The coal feed system is shown in Figure 5. The dual feed system was selected in order to provide redundancy and to avoid potential operating interruptions brought about by malfunctions in this sensitive area of the process. Each feed train is capable of providing a coal flow of approximately one ton per hour to the gasifier.

The gasifier and coal feeding system are designed to operate at pressures up to 300 pounds per square inch gauge (psig). The coal is fed through the two pressurized lockhoppers equipped with pressure isolation ball valves. When the lockhoppers are filling, the lower ball valves are closed, isolating the gasifier. Nuclear level detectors are utilized to determine when the hoppers are empty.

When coal is charged into the gasifier, the upper lockhopper valves are closed, isolating the gasifier system feed hopper. The coal is metered by a rotary feeder and driven into the gasifier by a screw conveyor. The rotary and screw feeders provide a continuous coal feed to the gasifier. The rotary feeders are adjusted to maintain the desired gasifier throughput (as determined by the bed level). The screw feeders form a high-speed, positive displacement device which transports the coal from the metering device to the reactor bed fast enough to preclude the swelling and devolatilization problems associated with bituminous coals. Experience has shown that a continuous feed will avoid the wide temperature and constituency fluctuations in the product gas caused by intermittent charging of coal.

As the coal passes down through the gasifier, the volatile matter and carbon are consumed and the remaining ash passes through the grate and is collected in the bottom of the gasifier. This ash buildup is periodically discharged 


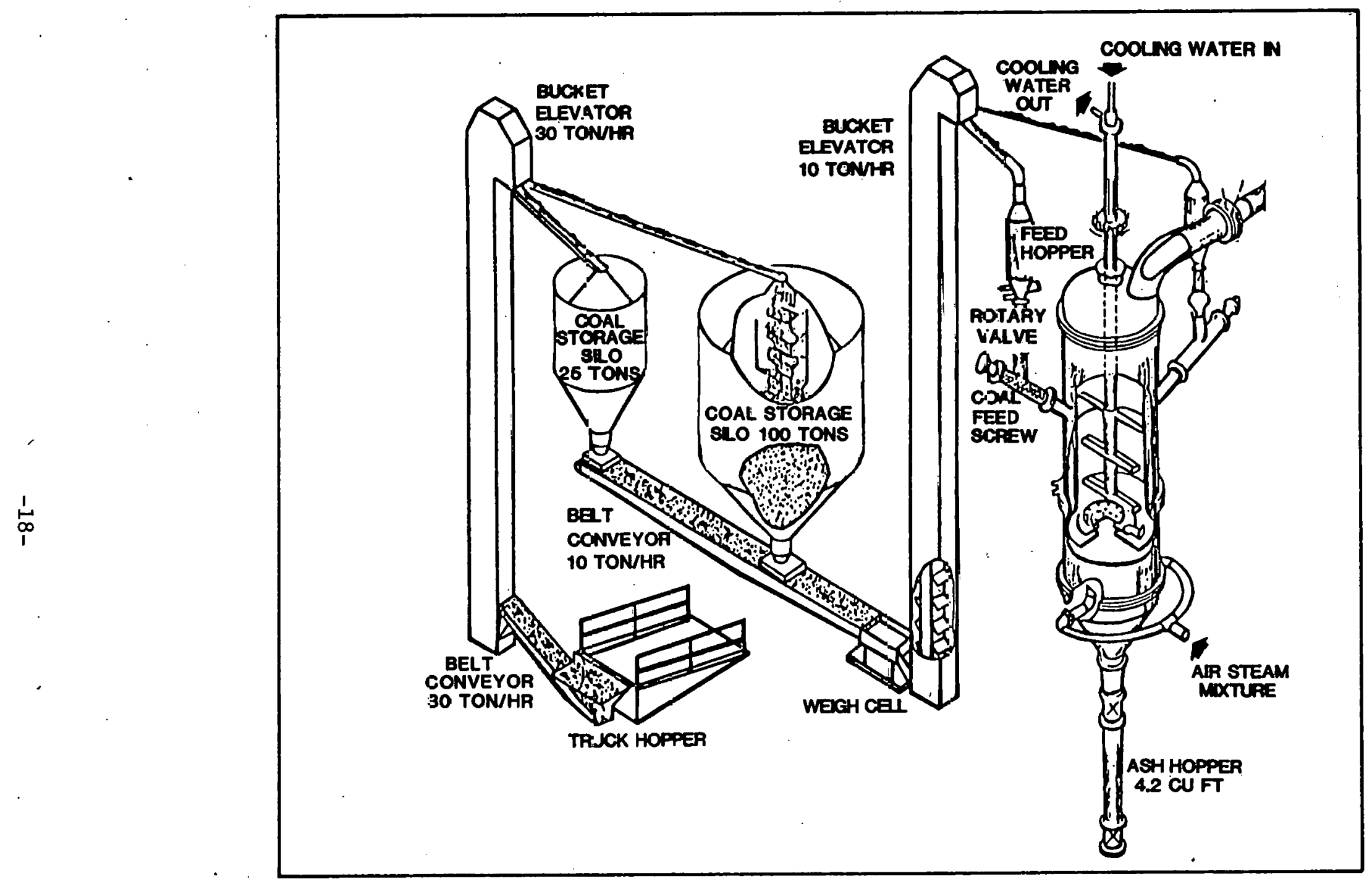

FIGURE 4. METC PRESSUZIZED GASIFIER AND COAL HANDLING SYSTEM 
from the gasifier into the ash letdown hopper. The ash letdown hopper functions similarly to the coal feed lockhopper, although. in reverse. Pressure isolation valves on either end of the ash hopper allow ash to be introduced into and discharged from the hopper by gravity while at all times maintaining pressure isolation of the gasifier vessel.

Figure 6 shows an early version of the gasifier with a gravity coal feed, ash hoppers, and isolation valves. The gasifier has a 3.5-foot inside diameter and an overall length of nearly 28 feet. The upper surface of the grate is located 12 feet above the gasifier ash pit discharge flange. Air and steam are introduced below and flow up through the grate. A water-cooled stirrer arm is rotated in the coal bed above the grate. The arm al so moves vertically through the coal bed and normally traverses a path from one to four feet above the grate.

A current, more detailed sectional view of the gasifier is shown in Figure 7 . The lower portion of the steel gasifier shell is water-jacketed, while the upper section is expanded and lined with a refractory to the same inner diameter. The coal bed is normally controlled at a fixed depth (typically in the range of six to eight feet) and is supported by an eccentric rotating grate. The periodicity of the intermittent grate rotation controls the rate at which ash is removed from the bed and, consequently, the rate at which coal must be introduced in order to maintain a constant bed level. The eccentricity of the grate plates acts to crush any ash clinkers that may form in the gasifier between the grate and a Bosh ring protecting the steel gasifier walls.

The stirrer consists of a vertically mounted rotating shaft with horizontal arms. Both the shaft and arms are water-cooled. The purpose of the stirrer is to ensure a uniform gas distribution in the coal bed, both eliminating the formation of channels within the coal bed and breaking up any soft agglomerations which are typically formed when operating with caking coals. Coal swelling and agglomerating conditions, existing inside the gasifier, tend to plug sections of the gasifier and create bridging conditions. This restricts gas flow and significantly decreases throughput, carbon conversion, and efficiency.

Pressurized air and superheated steam are mixed and injected into the lower section of the gasifier. The air and steam pass up through the grate and into the coal bed. The grate is designed to evenly distribute the air/steam flow, which in turn helps cool the grate.

The chemical reactions taking place in a fixed-bed gasifier can be more easily understood if the coal bed is divided into the different reaction zones shown in Figure 8.

The topmost part of the coal bed acts as a drying zone. As the coal is fed into the gasifier from the top, it contacts the hot gases generated below. These gases heat the coal and evaporate the moisture. The temperature of the coal, which is now dry, continues to increase as the coal proceeds further into the bed. This preheating of the coal causes the trapped and dissolved hydrocarbon gases and liquids to boil off and escape from the coal particles. This process is called pyrolysis or devolatilization. After devolatilization, the coal is predominantly char or carbon plus ash. This carbon reacts with 


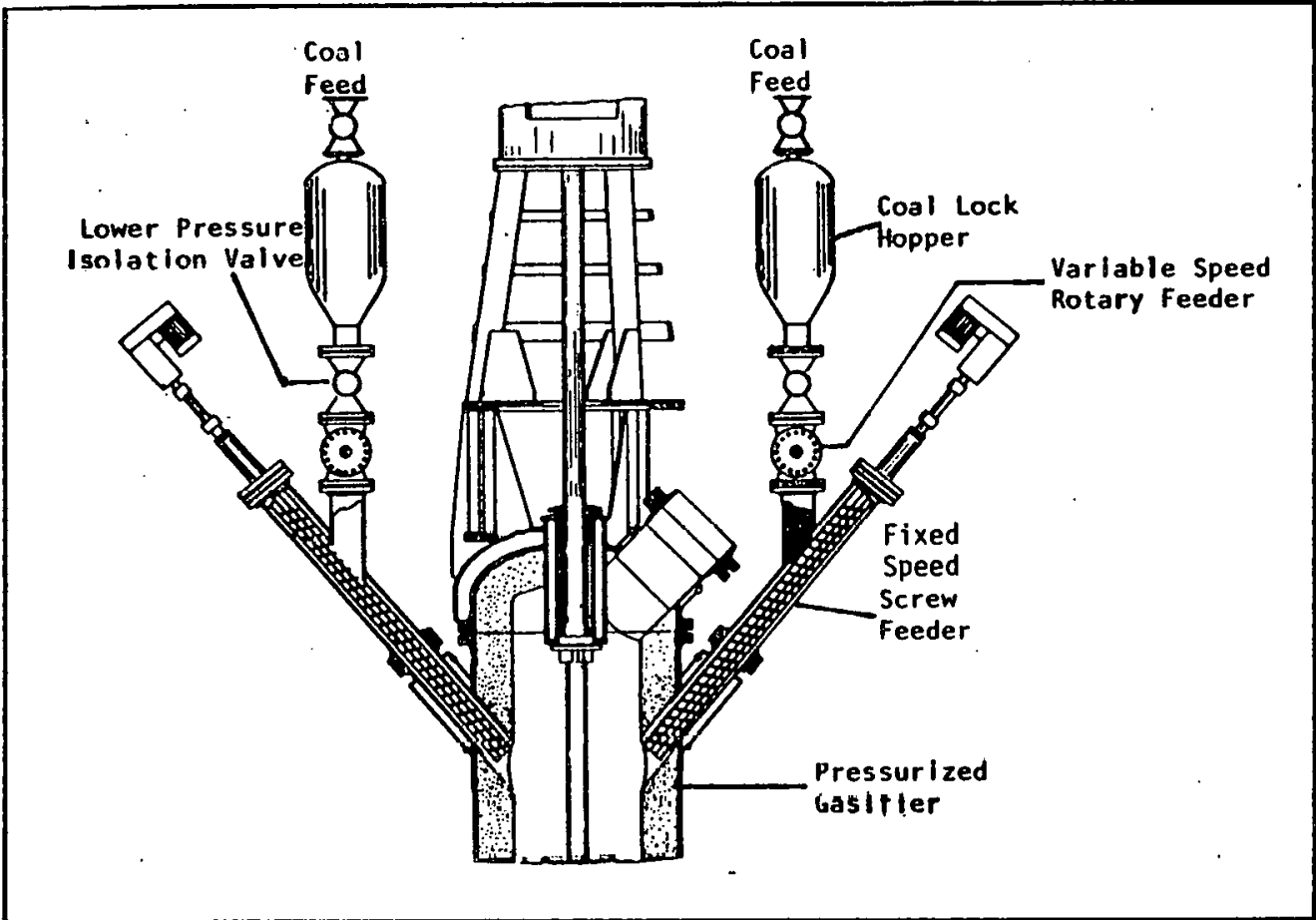

FIGURF 5. PRESSURIZED COAL ICLDING SYSTEM

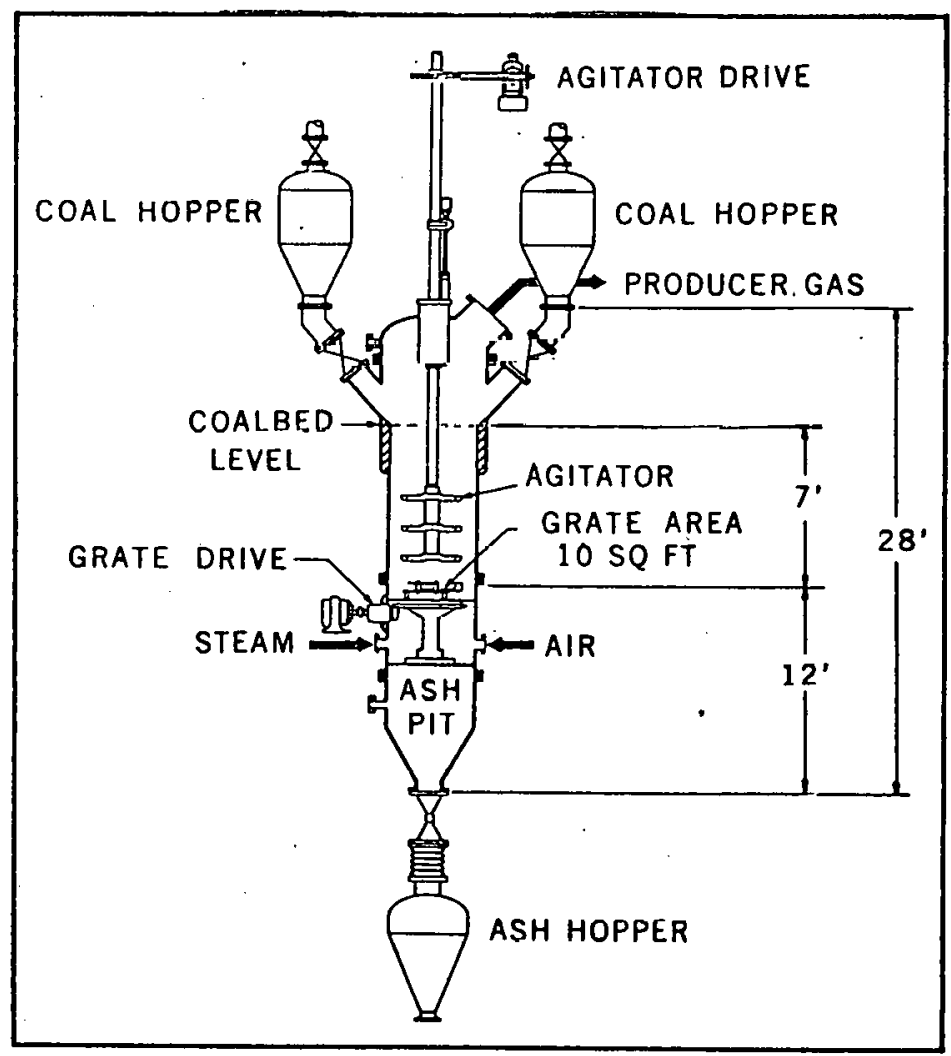

FIGURE 6. EARLY VERSION OF FIXED-BED GASIFIER 


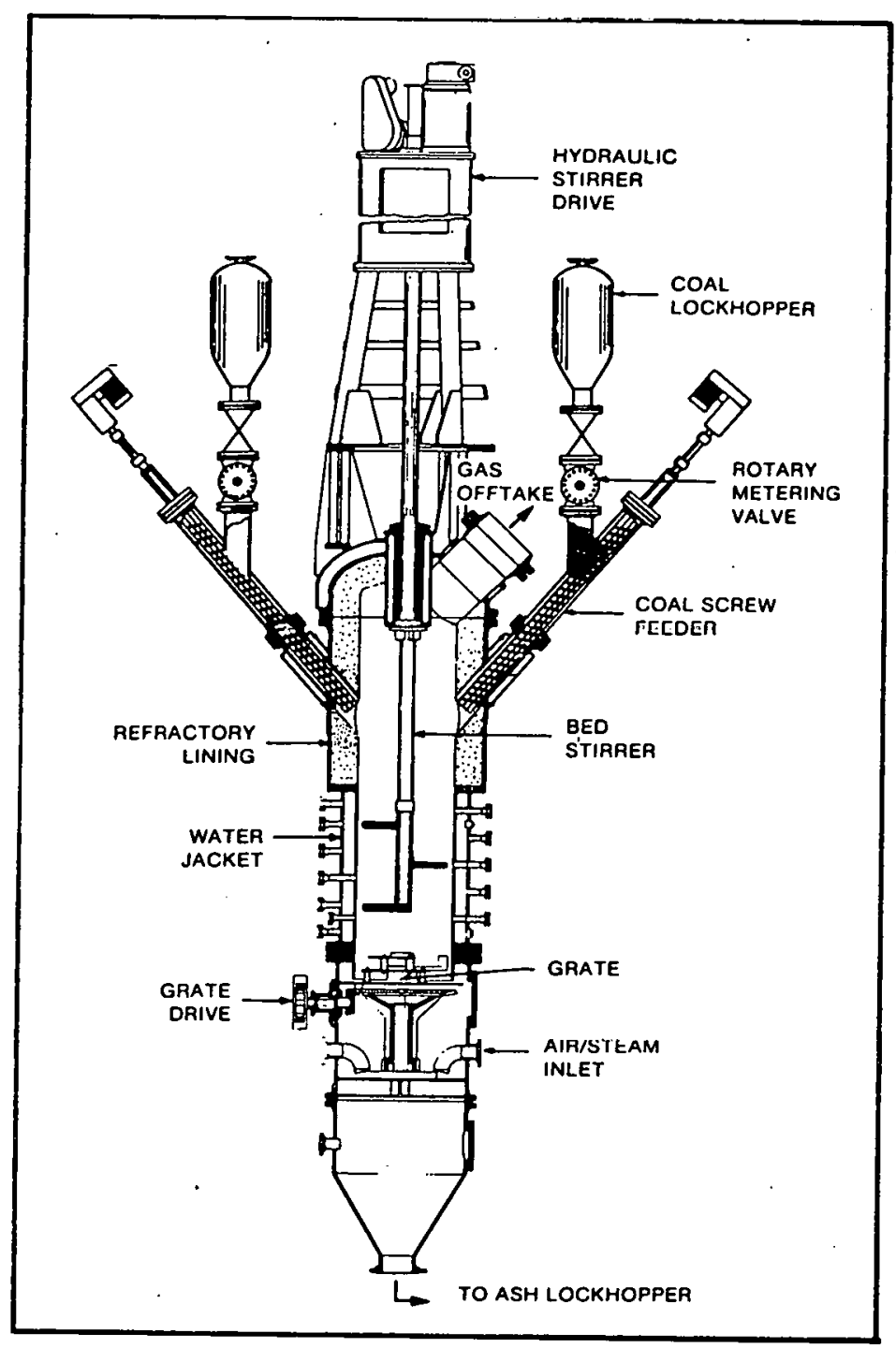

FIGURE 7. SECTIONAL VIEW OF CURRENT FIXED-BED GASIFIER 


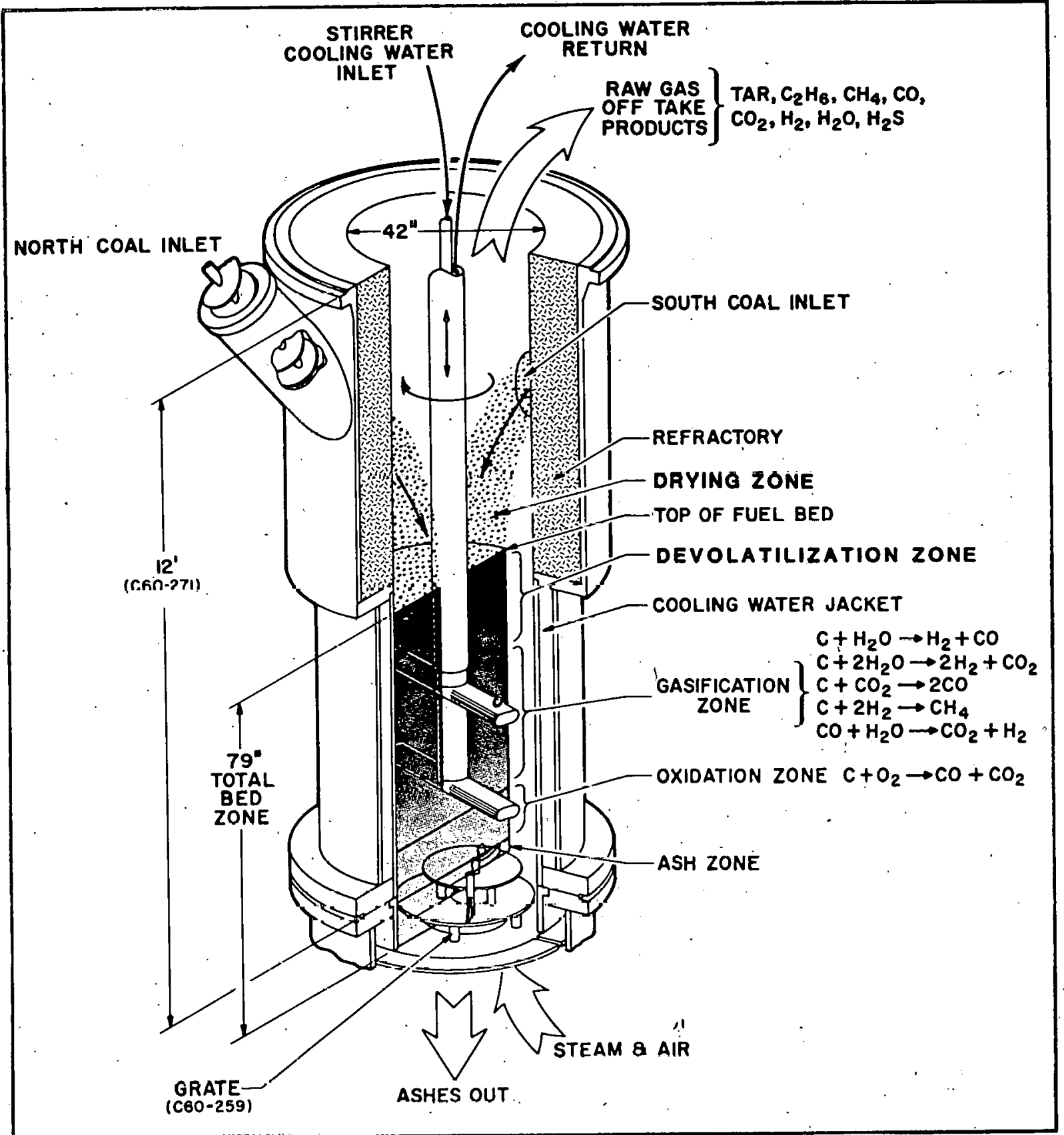

FIGURE 8. GASIFIER REACTION ZONES 
water $\left(\mathrm{H}_{2} \mathrm{O}\right)$, hydrogen $\left(\mathrm{H}_{2}\right)$, and carbon dioxide $\left(\mathrm{CO}_{2}\right)$ in the gasification zone to produce fuel gas products which are primarily $\mathrm{h}_{2}$ and carbon monoxide $(\mathrm{CO})$ and methane $\left(\mathrm{CH}_{4}\right)$.

The gasification reactions are endothermic and ideally occur at temperatures above $1500^{\circ} \mathrm{F}$. Heat input is required to bring the reactants up to temperature and to provide the reaction heat. The oxygen in the air stream combines with coal to supply this necessary heat in the oxidation zone which starts about one foot above the grate. A 12- to 18-inch layer of ash between the oxidation zone and the grate insulates the grate from the high combustion temperatures $\left(>2000^{\circ} \mathrm{F}\right)$. The ash layer also serves to preheat the air and steam. Control of the quantity of steam flow to the gasifier determines the oxidation zone temperature. This control helps prevent ash slagging which can damage the grate and upset gas flow distribution. The steam also participates in the gasification process, reacting with carbon and $\mathrm{CO}$ to produce hydrogen. In this oxidation process, nearly all the remaining carbon is converted to $\mathrm{CO}$ and $\mathrm{CO}_{2}$.

Operation at elevated pressure aids the gasification process by increasing coal throughput for a given reactor volume. Higher pressure, greater than 3 atmospheres, al so promotes methane formation by shifting reaction equilibrium points. For this reason, higher-pressure processes are favored for production of synthetic natural gas (to increase the equilibrium yield of methane), while low-pressure, atmospheric processes are favored for production of synthesis gas $\left(\mathrm{H}_{2}\right.$ and $\left.\mathrm{CO}\right)$.

Either oxygen or air can be utilized as the source of oxidant for the gasification reaction. In the case of air, the major difference is the effect of nitrogen dilution of the product gas, which reduces the specific heating value of the dry gas by approximately 50 percent. Industrial heating applications and potential combined-cycle gas-turbine combustion applications, which are not significantly affected by the nitrogen dilution of the gas, can utilize ordinary air. This eliminates the expense and complexity involved in supplying pure oxygen. Gasification systems employing oxygen are primarily those utilizing the $\mathrm{H}_{2}$ and $\mathrm{CO}$ in the gas as a reactant in downstream chemical processes.

As the coal is heated in the gasifier, the entrapped hydrocarbon gases and liquids boil off and are swept out of the gasifier with the fuel gas stream. If the product gas is to be cooled for transport, compression, and/or sulfur removal, these heavy hydrocarbons will condense as tars and oils. To avoid plugging and fouling of downstream equipment, the fuel gas must be cooled and the tars and oils must be removed and collected in a careful and controlled manner. In addition to the tars and oils, the fuel gas contains potentially toxic substances including phenols, ammonia, and sulfur gases which must be separated and disposed of properly. The development of process systems, equipment, and procedures to accomplish this in an efficient and cost effective manner is the subject of Section 3.2. Data description is provided in Section 5.4 and pollutant production synopsis is given in Table 39 . 


\subsection{GAS CLEANUP SYSTEM DESCRIPTION}

Gas produced by coal gasification processes has many potentially attractive uses, such as: industrial process and space heating fuel, gas turbine fuei for combined-cycle power generation, fuel cell reactant feed, and chemical feedstock to generate ammonia, methanol, and a wide range of other chemicals.

Preparing the gas for the above applications is complicated by the fact that the raw product gas leaving the gasifier contains gaseous, liquid, and solid contaminants, any or all of which may be unacceptable to the end user. A listing of the recognized contaminants follows:

- Particulates -- ash and unburned coal

- Condensable tars and oils

- Ammonia

- Phenols

- Sulfur gases -- hydrogen sulfide $\left(\mathrm{H}_{2} \mathrm{~S}\right)$, carbonyl sulfide $(\mathrm{COS})$, carbon disulfide $\left(\mathrm{CS}_{2}\right)$, etc.

- Alkali metals -- primarily sodium and potassium

- Heavy metals -- primarily vanadium

Only the simplest 'combustion processes can use the raw, coal-derived gas directly, and only when the combustion process is closely coupled with the gasifier and is not restricted by limitations in the flue gas sulfur content. If the combustor is located at a distance from the gasifier, the raw gas will cool and tars will condense, plugging gas lines and burner equipment. Tars produced in the coal gasification process cover a wide spectrum and include high-melting, high-boiling, semi-solid, pitch-like materials. Analysis of these materials is presented in Section 5.3.1. Obviously, if the gas is to be transported and distributed for any distance, the tars and oils must be removed. For potential gas turbine use, stringent 1 imitations have been placed on allowable particulate loadings in order to control turbine blade erosion. The presence of alkali metals in the gas stream presents corrosion problems for high-temperature turbine materials. Gas turbine industry fuel specifications, when translated to a $150 \mathrm{Btu} / \mathrm{SCF}$ fuel gas, make it necessary to hold the alkali metal concentration to less than one part per million. Fuel cell uses similarly require very low particulate loading and the removal of ammonia and sulfur to levels below one part per million. The phosphoric acid cell is sensitive to ammonia, and the molten carbonate cell is sensitive to sulfur. Table 40 compares the limits for advanced technology applications with the levels currently measured in the gas stream.

\subsubsection{Side-Stream Cleanup System}

METC is engaged in investigating and developing gas cleaning systems and techriques that will apply to all of the above uses. Initial gas cleanup tests used conventional gas processing components, and the ability to clean a 
side-stream of the main gas stream was demonstrated. The side-stream cleanup train processed approximately 20 percent of the total gas flow. This approach, utilizing small-scale components for the initial development and testing, was adopted in order to minimize equipment costs and the turnaround time associated with the trial-and-error testing of various cleanup train configurations. The purpose of this testing was to demonstrate that the gas could be cleaned to the exacting levels demanded by some of the advanced applications being considered for coal-derived fuel gases, and also to provide a basis for designing the FFCUS.

Several cleanup system configurations were tried. In all of these configurations, the main gas flow stream passed through a particulate removal cyclone to a flare stack.

First Side-Stream Cleanup System Configuration. The first side-stream cleanup train configuration is shown in Figure 9. Data and a discussion of the results of these tests is included in Section 5.2.1. The cleanup train consisted of a humidifier and disengagement chamber (tar separator), a venturi scrubber and cyclone, and a valve-tray scrubber and knock-out drum. The sidestream then joined the main gas stream to the flare stack. In this configuration, gases flowed directly from the gasifier to a humidifier where oncethrough water was sprayed. The water evaporated into the gas stream, lowering the temperature so that it approached the saturation point. The condensing tar droplets were carried with the gas stream out of the humidifier into the disengagement chamber or tar separator. This tar separator vessel provided a volume where the tar droplets could coalesce and drop out of the gas stream. In the process of evaporating the spray water, the gas stream was cooled from the $800-1200^{\circ} \mathrm{F}$ level to approximately the $320-360^{\circ} \mathrm{F}$ level.

At the latter temperature range, the heavy tars condensed out of the raw gas stream. The gas then entered the venturi scrubber where additional water cooled it to $110-120^{\circ} \mathrm{F}$. The remaining tars and most of the light oils condensed at this temperature. The gas was dewatered by cyclone separation before passing through a four-plate valve tray scrubber for final polishing with additional water. The gas exited the tray scrubber at approximately $85^{\circ} \mathrm{F}$, at which point the majority of all the tars, oil, and particulates were removed. The synopsis of these data are provided in Section 5.4.2.

Preliminary Gas Turbine Combustion Tests Configuration. A preliminary program was conducted on a turbine siumlator test rig in order to evaluate the combustion characteristics of coal-derived low-Btu gas in a prototype gas turbine combustor, and in order to determine the erosive and corrosive potential of the combustion gases on turbine materials. A schematic of the test rig is shown in Figure 10. This test program was performed in cooperation with the General Electric Company (Day 1977).

The objective of this program was to provide engineering data on the performance of selected gas turbine nozzle and bucket materials in low-Btu combustion gas environments. Natural gas was burned in the preheater to heat. air to $570^{\circ} \mathrm{F}$, simulating gas turbine conditions. This preheated air was burned with cleaned low-Btu gas in the combustor section, raising the temperature to between $1750^{\circ}$ and $1830^{\circ} \mathrm{F}$. The combustion gases flowed through the inside of the combustor section and passed over the cooling pins, sensors, and turbine element test specimens. 


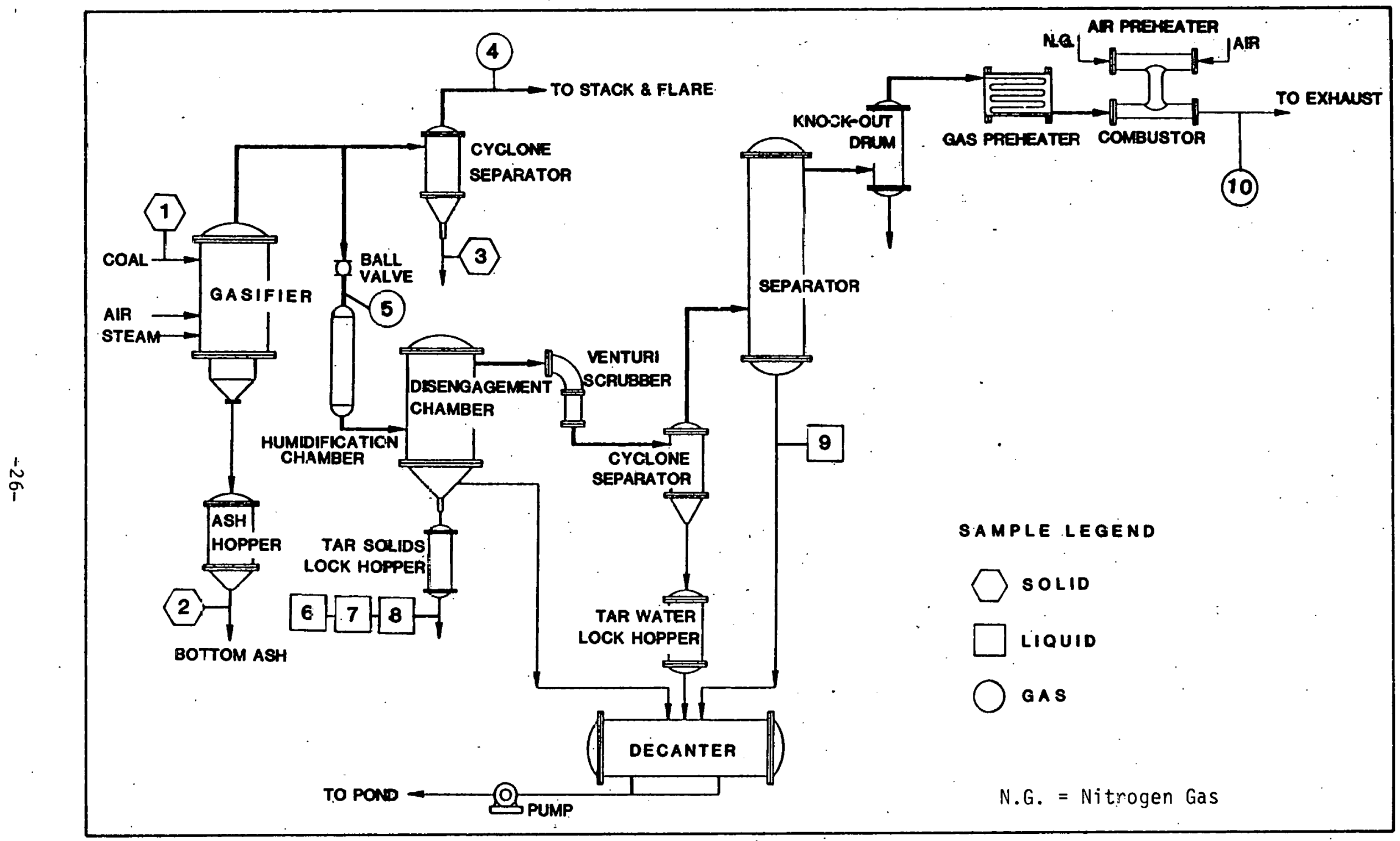

FIGURE 9. FIRST SIDE-STREAM GAS CLEANUP TRAIN CONFIGURATION 


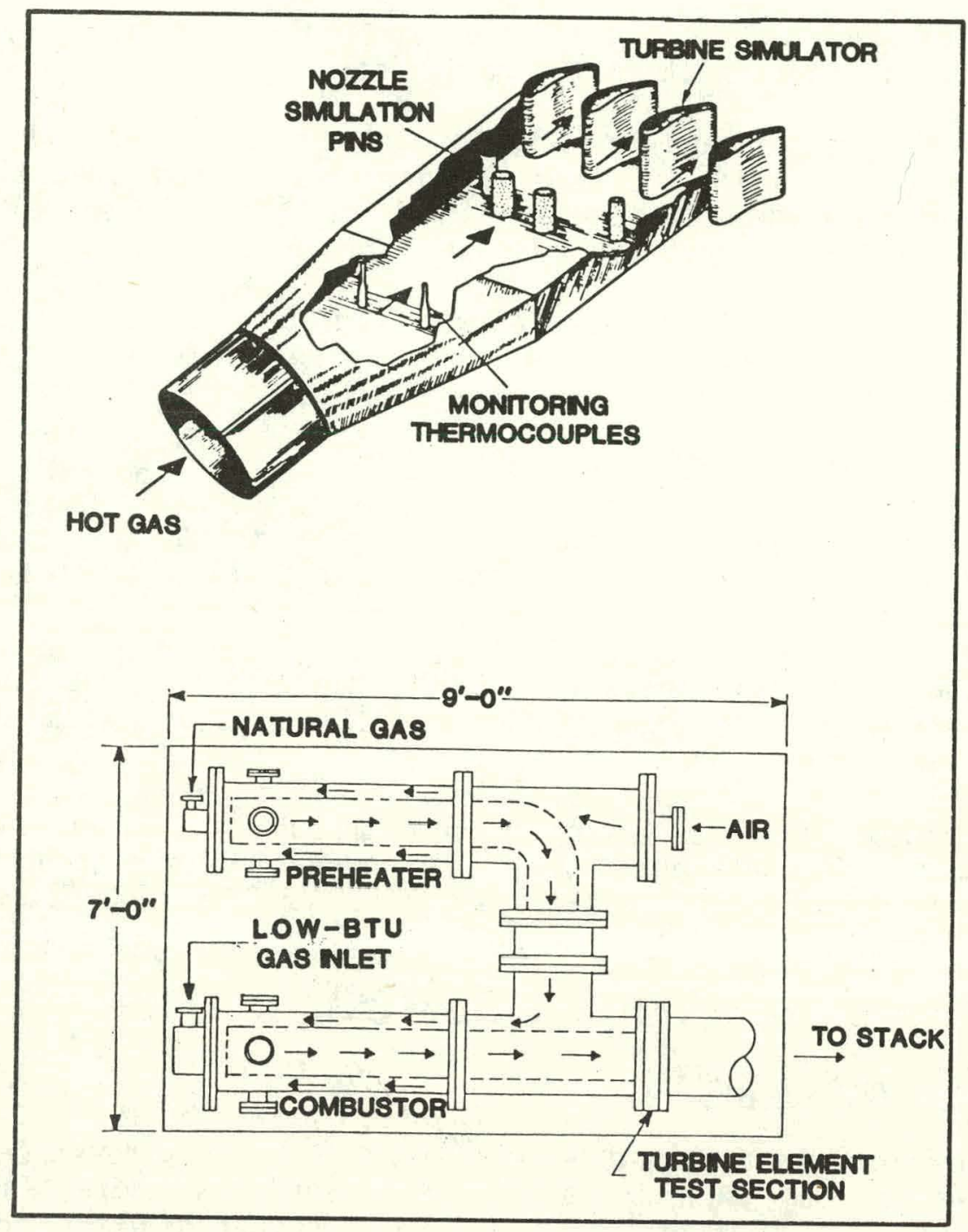

FIGURE 10. TIIRBINE MATERIALS - COMBUSTION TEST RIG 
Second Side-Stream Cleanup System Configuration. The second series of sidestream tests incorporated several major changes in the cleanup system configuration (Figure 11):

- The low-Btu gas path included the particulate removal cyclone to reduce dust loadings input to the humidifier.

- The venturi scrubber and downstream cyclone were removed from the cleanup train in order to simplify the system and investigate the potential of performing the entire light tar and oil removal function with the valve-tray scrubber/knock-out drum configuration.

- The waste water decanter system was upgraded to collect all the scrubbing water streams so that this water could be filtered and recycled back to the process units.

Data from these tests are described in Section 5.2.3.

Third Side-Stream Cleanup System Configuration. The third series of sidestream tests used the same basic configuration as the second series, with one change and one addition:

- A two-phase nozzle was installed in the humidifier. The nozzle used nitrogen to attempt to atomize the scrubbing liquor, with the intent of producing droplets one to five microns in size.

- A packed-column scrubber using a once-through water wash was added downstream of the knock-out drum. The purpose of this scrubber was to demonstrate removal of trace quantities of alkali metals, namely sodium and potassium, to levels required for gas turbine operation.

Data from these tests are described in Section 5.2.4.

\subsubsection{Full-Flow Cleanup System}

Ihe FFCUS configuration was designed on the hasis of prior side-stream tcsting and is being developed as an alternative to conventional deluge-quench gas cleanup technology. The METC approach is novel compared with conventional coal gasification gas cleaning because it features sequential removal of particulates, tars, oils, sulfur, alkali metals, and other trace contaminants in the order shown in Figure 12. By producing individual effluent streams, the level of dust/tar/oil/water separation and subsequent processing that current commercial deluge-quench technology entails is dramatically reduced. A key development in the METC process is the humidifier, vessel which removes the high-molecular-weight hydrocarbons in a manageable "dry-tar" state. A study comparing the two systems on a process technology and economic hasis was sponsored by MEIC. The study was based on the commercial-scale application of the METC "dry-tar" gas cleanup system using raw gas from an air-blown fixedbed gasifier using Pittsburgh seam coal. This study concluded that the METC system was a viable and possibly a superior alternative to the conventional 


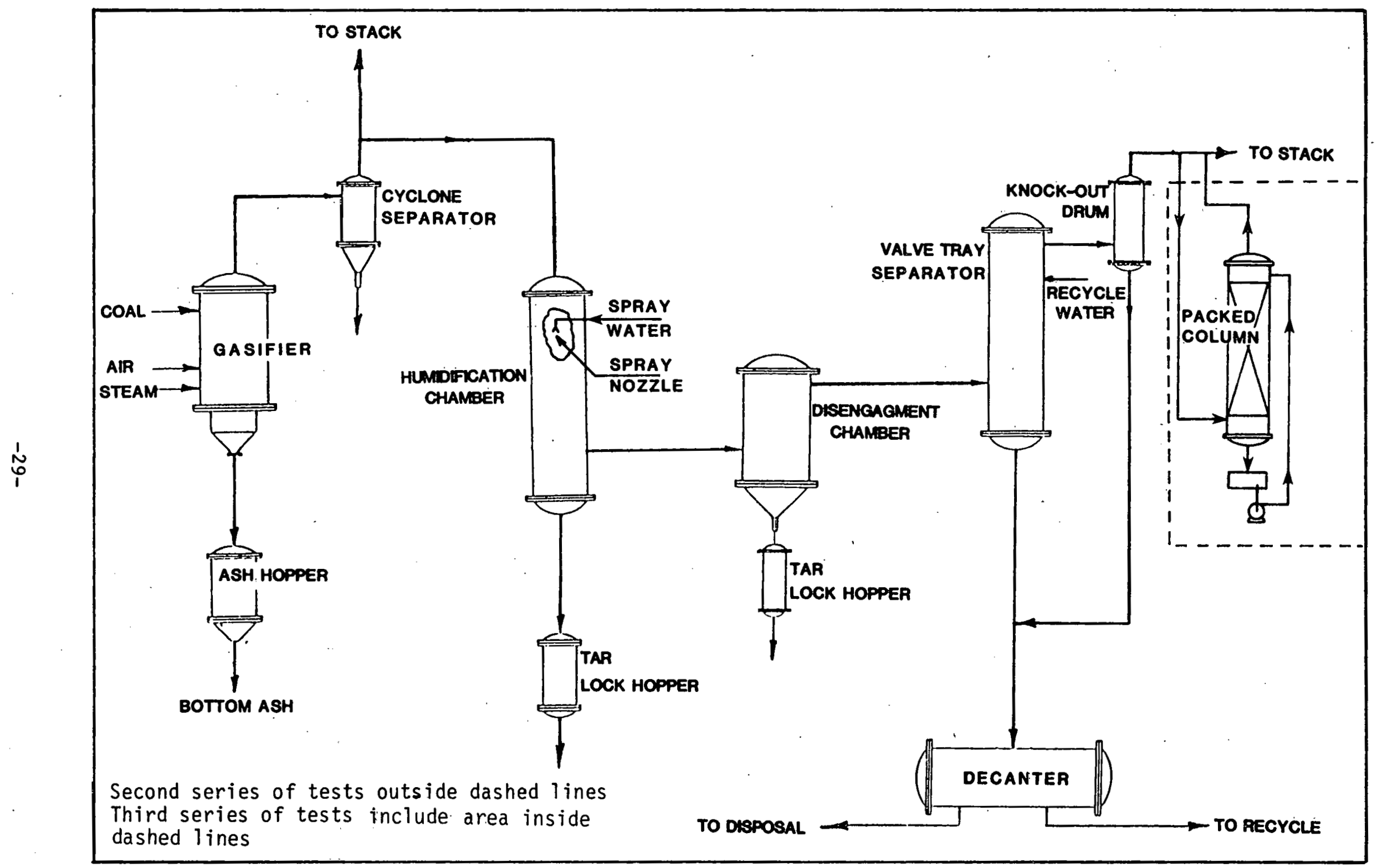

FIGURE 11. MODIFIED SIDE-STREAM CLEANUP CONFIGURATION 


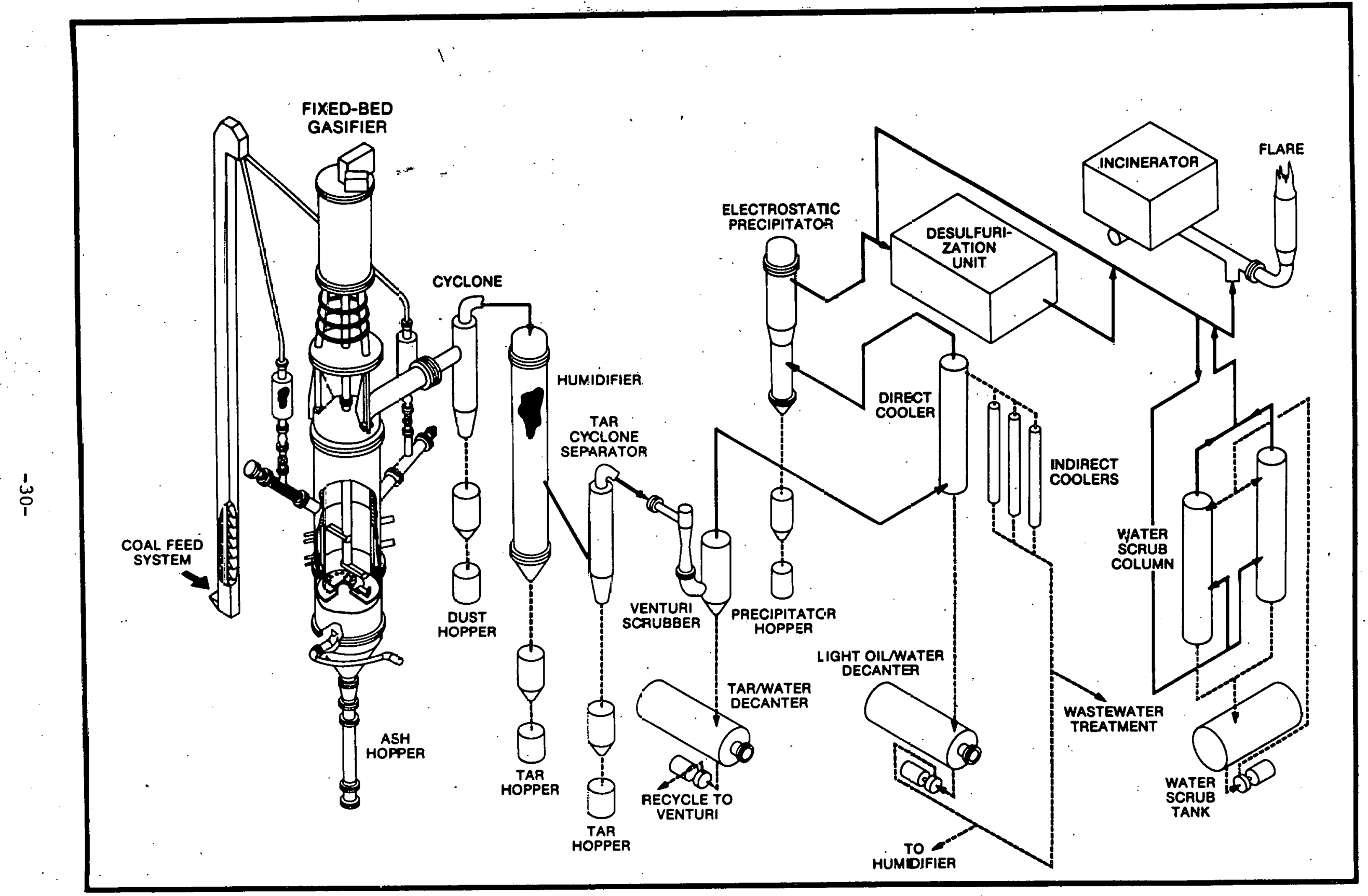

FIGURE 12. CURRENT CONFIGURATION OF FIXED-BED GASIFIER AND FULL-FLOW CLEANUP SYSTEM 
deluge-quench gas cleanup system. The study also found the METC system approach appears to be better environmentally and to have more operational flexibility when considered on a total facility basis. The basic system is described below, and the development and test results of this system are described fully in Section 5.3.

As shown in Figure 12, raw gas from the gasifier at approximately $1000^{\circ} \mathrm{F}$ and up to 300 psig enters a low-velocity cyclone where 85 to 90 percent of the entrained particulates, primarily char, are separated from the gas. Removal of this dust reduces the viscosity of tars condensing downstream by reducing the solids loading to a manageable state. The dust is recovered through a lockhopper and if agglomerated, is available for recycle to the gasifier. The cyclone outlet gas is next treated in the humidifier vessel.

In the humidifier (see Figure 1 in Section 1 of this report) recycle water (atomized by single-phase spray nozzles) is used to cool the incoming gas stream (approx. $1000^{\circ} \mathrm{F}$ ) to a temperature that is $25-50^{\circ} \mathrm{F}$ above its dew point $\left(300-400^{\circ} \mathrm{F}\right)$. This results in the condensation of high molecular weight tars: A viscous tar stream exits the system through a lockhopper in a "dry-tar" state that is fluid at $>200^{\circ} \mathrm{F}$ but solidifies at room temperature. Before the present configuration was determined, this process step was the subject of extensive development activities involving vessel size parameters, development and testing of two-phase atomization nozzles, and a study of the suitability of a spinning disc atomizer. The vessel size was expanded to feasible limits to provide adequate cooling, but did not provide adequate tar removal. The nature of the tar aerosol formed as a result of the temperature reduction in the humidifier is such that simple gravity separation does not fully separate the droplets from the gas. Consequently, a separator was added downstream from the humidifier to remove tar droplets not captured in that vessel. Various configurations of droplet separators were evaluated for facilitating tar removal performance (see Section 5.3.1). A cyclone-type design was selected as adequate for this severe service. The effluent tar stream is removed through a lockhopper.

The gas then flows to a venturi scrubber where a very fine tar mist, not removed by the humidifier or tar trap, is separated from the gas stream. This process utilizes recycled venturi scrubber water (liquor) which is separated from the tar stream in a pressurized decanter vessel. The effluent tar stream contains some lighter oils and consequently, this tar remains liquid at room temperature.

After the venturi scrubber, the gas stream flows to a direct cooler operating with recycled water (liquor) and is cooled to approximately $100^{\circ} \mathrm{F}$. This is the only nonadiabatic step in the process. This cooling step condenses and removes the unconverted steam fed into the gasifier, the water atomized in the humidifier, and the condensable light oils from the gasification process. This gas cleanup system approach results in the liquid condensate from the system being accumulated at system pressure in the direct cooler decanter. 'A major virtue of this approach is that the mid-level of this decanter liquor is sufficiently "water-like" to be directly recyclable without any of the depressurization or treatment steps required in "conventional" systems. The recycle water is pumped from the decanter mid-level through indirect coolers (shell and tube heat exchangers) wherein the heat energy originally extracted from the gas is transferred to process water and leaves the system. There are 
three small byproduct liquid flows from the decanter. The largest is "surplus" water which is actually the fraction of steam introduced to the gasifier that was not converted into product gas. This is the only wastewater stream that must be treated, and the treatment scheme requirement is dictated by the disposition (e.g., in-plant re-use, sanitary discharge). The other two streams are still smaller in volume and are highly fluid, water insoluble, low-boiling-point oils with specific gravities above and below that of the water-like liquor. This method of operation produces a wastewater that is potentially more easily treated than that produced by a deluge-quench system. This is because of the reduction in contact time of the waste waters with the heavy tars, reducing the level of water-soluble hydrocarbons such as polynuclear aromatics (PNAS) in the effluent stream.

Next, the gas flows through an electrostatic precipitator (ESP) in order to reduce any remaining hydrocarbon mists, since the Holmes-Stretford desulfurization unit (HSDU) is sensitive to a buildup of contamination by hydrocarbons. The gas then goes to the desulfurization unit (see Section 3.2.3) where the major sulfur-containing constituent in the gas stream, hydrogen sulfide $\left(\mathrm{H}_{2} \mathrm{~S}\right)$, is removed. Following desulfurization, the gas stream passes to a water scrub column for removal of trace alkali metals that may have been introduced during desulfurization, since these materials can produce severe corrosion and erosion damage in gas turbines.

\subsubsection{Holmes-Stretford Sulfur Removal System}

In the coal gasification process, most of the sulfur in the feed coal is converted to hydrogen sulfide and to lesser amounts of carbonyl sulfide and carbon disulfide gases. METC has installed a Holmes-Stretford unit which will remove the hydrogen sulfide from the product gas stream. The commercially proven Stretford process can reduce the amount of sulfur in the gas stream to a few parts per million, and can convert this sulfur to an inert, solid byproduct. However, the process has not been proven in a pressurized gasification application. Successful demonstration at Morgantown will resolve one more area of technical uncertainty in coal gasification, and in addition, will provide the opportunity for generating a design data base for the integration of the Stretford process into other gasifier cleanup train systems.

The unit installed at METC was designed and fabricated by Peabody Engineering Systems. A flow schematic for the Stretford process is shown in Figure 13. The METC system utilizes a venturi scrubber to scrub the $\mathrm{H}_{2} \mathrm{~S}$ from the producer gas, as shown in the schematic. The venturi option is much smaller than the wooden-grid absorber towers normally associated with past Stretford system designs. However, it results in a somewhat larger pressure loss. For pressurized gasification systems, the higher pressure loss is usually not critical and the venturi option is generally more suitable. The venturi removes approximately 80 percent of the $\mathrm{H}_{2} \mathrm{~S}$ in the raw, low-Btu gas. Final cleanup of the gas stream to low-ppm levels is achieved in a small tray tower situated above the venturi. This absorber allows intimate mixing of the gas with the Stretford solution. In the venturi and absorber, the cooled low-Btu gas contacts an alkaline solution which contains a vanadium salt with an anthraquinone derivative. The $\mathrm{H}_{2} \mathrm{~S}$ in the gas stream is converted to elemental sulcur while the vanadium saft is reduced by the following reactions: 


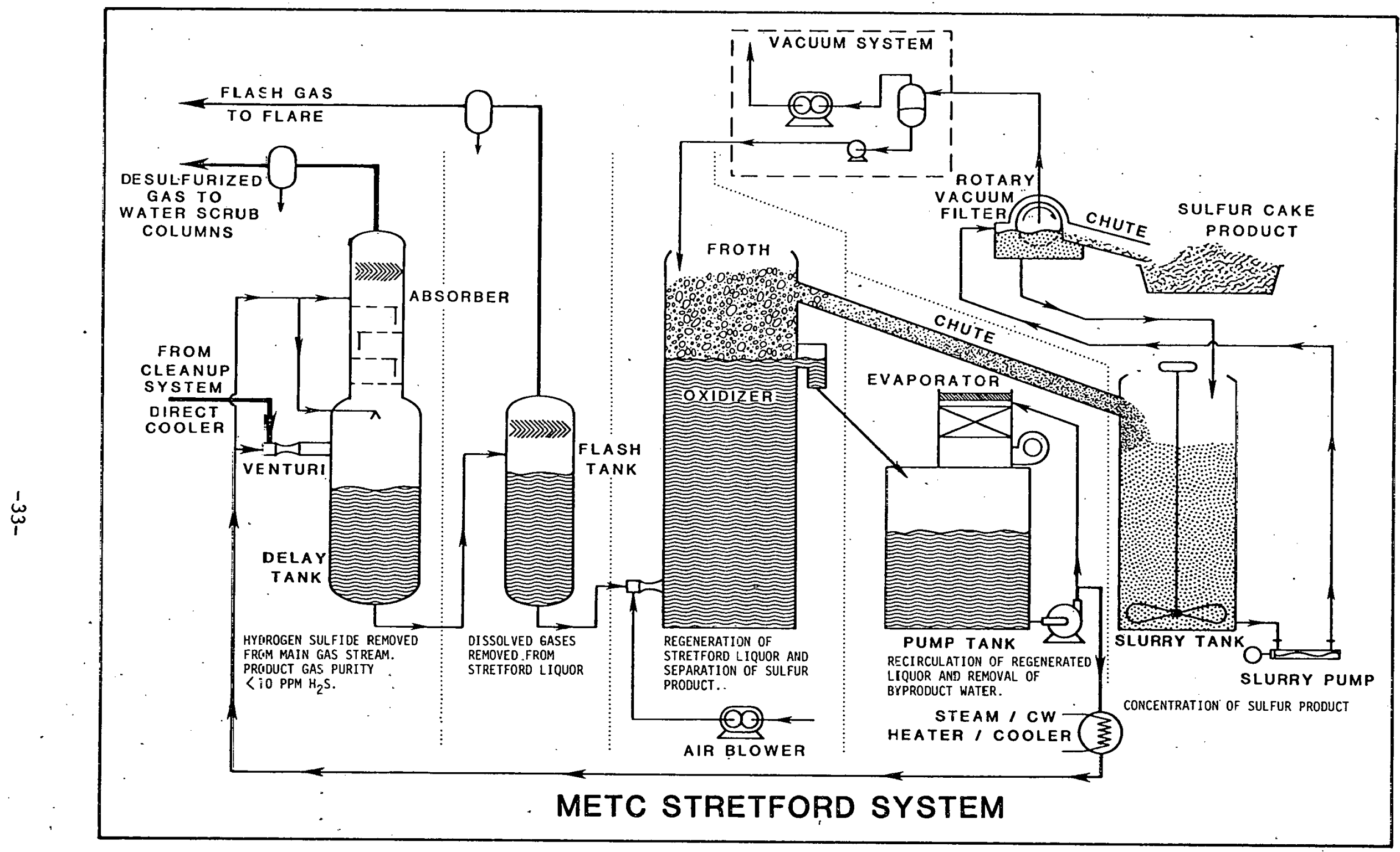

FIGURE 13. STRETFORD HYDROGEN SULFIDE REMOVAL SYSTEM 


$$
\begin{aligned}
& \mathrm{Na}_{2} \mathrm{CO}_{3}+\mathrm{H}_{2} \mathrm{~S} \leftrightharpoons \mathrm{NaHS}+\mathrm{NaHCO}_{3} \\
& \mathrm{HS}+2 \mathrm{~V}^{5+} \leftrightharpoons 2 \mathrm{~V}^{4+}+\mathrm{S}+\mathrm{H}^{+}
\end{aligned}
$$

A delay tank located below the absorber provides the necessary residence time interval for the chemical reactions to proceed before the solution goes to an oxidizer tank. Since the oxidizer tank is vented to atmosphere, a flash tank is positioned between the delay and oxidizer tanks in METC's pressurized system. The flash tank depressurizes the solution and releases the dissolved gas from solution. These gases (typically small quantities of nitrogen or $\mathrm{N}_{2}$, $\mathrm{CO}, \mathrm{CO}_{2}, \mathrm{H}_{2}$, and hydrocarbons or $\mathrm{HC}$ ) are vented to the flare stack and combusted. The solution is then fed to the oxidizer where air is blown through the liquor to reoxidize the solution and separate the sulfur by flotation. In the oxidizer, anthraquinone disulphonic acid (ADA) reacts with the 4 valent vanadium, converting it back to the 5 valent form and is itself reduced:

$$
\mathrm{v}^{4+}+\mathrm{ADA} \leftrightharpoons \mathrm{v}^{5+}+\mathrm{ADA}_{\text {reduced }}
$$

The oxygen in the air converts this reduced ADA back to the oxidized state.

$$
A D A_{\text {reduced }}+\mathrm{O}_{2} \leftrightharpoons A D A+\mathrm{H}_{2} \mathrm{O}
$$

The overall simplified Stretford reaction is:

$$
\mathrm{H}_{2} \mathrm{~S}+\mathrm{O}_{2} \leftrightharpoons 2 \mathrm{H}_{2} \mathrm{O}+2 \mathrm{~S}
$$

The sulfur formed in this process is a finely divided particulate which is floated to the top of the oxidizer by the rising air. stream. A froth containing approximately three to eight percent sulfur forms at the top of the tank and overflows into a slurry tank. The slurry is pumped to a vacuum filter which discharges the sulfur in the form of a washed, wet filter cake.

For large commercial gasification operations, where the recovery and sale of pure sulfur is economical, the sulfur product can be heated and melted to separate the water and impurities in order to produce a commercial-grade sulfur with greater than 99.5 percent purity. In METC's operation, because of the very small quantities involved, the inert wet sulfur cake is either stored or disposed of in an environmentally acceptable manner.

The underflow solution from the oxidizer is sent to a pump tank and after heating or cooling, depending on ambient conditions, is recirculated back to the absorber, completing the cycle. Data from testing of the Stretford is presented in Section 5.3.2.

\subsection{DESCRIPTION OF COMPLEMENTARY PROGRAMS}

The operation and testing of the METC fixed-bed gasifier arid cleanup system provides a vehicle for the implementation and testing of complementary programs both on- and off-site. These programs are important to the generation of a data base as wide as possible concerning all aspects of the technology. This Section summarizes the key programs implemented over the past few years in conjunction with the fixed-bed gasifier and cleanup system. 


\subsection{CONTROL SYSTEM IMPROVEMENTS AND INNOVATIONS}

Throughout the development of the METC gasifier and full-flow cleanup system, improvements and innovations in the control systems have been implemented. Two areas are described below.

Automatic Data Acquisition and Control System (ADACS). As the scope of the project increased due to the large number of process systems being tested, METC determined that an automated data acquisition and control system should be installed on the gasifier and FFCUS. ADACS was first implemented in early 1978 with automatic logging of data on magnetic tape. ADACS is now an integral part of the operation and control of the entire process facility, and performs the following functions for the operating technicians and test engineers:

- Logs data at desired interval (typically 30 seconds) onto tape for post-processing and analysis.

- Stores most recent five days of data on disk. These data can be retrieved on line for historical display, statistical analysis, comparison of operating conditions, and event analysis le.g., valve failurel.

- Provides trend display of data over any period. Display can cover any time span and any range for the data retrieved (e.g., 0-100 percent, $50-75^{\circ} \mathrm{F}, 0-200$ pounds per square inch or psi). Up to five data points at one time may be displayed.

- Plant mimics can be graphically displayed by the ADACS system. These are process diagrams of selected portions of the equipment including process data monitored by the computer. Either historical or current data may be displayed.

- Process calculations are performed on line by ADACS, converting millivolt readings into engineering units. In addition, complex calculations required for heat (energy) and material balance information are performed on line. ADACS is also used to perform data reduction of raw gas chromatograph information.

- Incoming data is checked against expected limits to verify that the instruments and sensors are functioning properly.

- ADACS is used during calibration of instrumentation to ensure the maximum accuracy possible for test data.

- ADACS provides statistical evaluation of data during testing to assist plant engineers with rapid evaluation of test conditions.

- ADACS calculates key parameters for comparison with actual operating data to determine if a process is furctioning properly (c.g., Btu output, efficiency). 
Integrated Control System. Operation of the FFCUS required the installation of additional instrumentation not required in the early phases of the gasification program. METC determined that a single control system should be constructed in order to consolidate the controls for the gasifier with the FFCUS. The new instrumentation is electronic (versus pneumatic) and is more compatible with the ADACS system. Installation of the controls and the transfer of the gasifier control to the new system was a major task. The nuclear level detectors on the gasifier were upgraded and other control instrumentation improvements were provided.

The major goals of Test Run 95 in the fall of 1980 were to test the new control system, tune the instrumentation for proper control element response, and acquaint the operators with the new system prior to initiation of the corrosion/erosion program.

The new instrumentation is versatile and can easily be modified as test program criteria warrant. The integration of the control instrumentation with the ADACS computer system has eased calibration and hastened modifications. The control instrumentation and ADACS are interrelated but not interdependent. Failure of the computer does not jeopardize plant operation. Similarly, the failure of a control component can be compensated for by monitoring its status on the computer. This redundancy provides a high measure of security for plant operation.

Other innovative activities more fully discussed in Section 5.1 include:

- The automation of coal feed, ash removal, and dust removal (including voice synthesizers for operator alarms). Automation of these batch systems relieves the operator of the need to concentrate so much attention on the hardware as previously required. This allows more time to monitor other operating parameters and assures smooth running conditions. A voice synthesizer was installed to provide status annunciation for the batch feeders without the distraction created by numerous bells, beepers, and hooters (see Section 5.1.1).

- The development and implementation of gasifier bed level control ut1l1zlng nuclear detectors. This was developed so that the coal feed rate could be adjusted to maintain a consistent bed level, regardless of changes in the gasifier operating parameters (see Section 5.1.2).

- Cascade control of the humidifier spray system. Humidifier outlet temperature control requires careful attention to controlling the spray water flow to each of four separate spray nozzles. Flow to each nozzle is only permitted from 50 percent to 100 percent of design to insure proper atomization of the spray water for optimum cooling. A control system to automatically maintain flow to each nozzle within the specified range and maintain constant humidifier outlet temperature, regardless of system throughput, was developed.

- Development and implementation of ash level control by means of temperature measurement on the rotating stirrer arms. Maintaining ash level at a constant depth is a key to uniform operation of the gasifier. Measurement of temperature within the moving bed is a difficult 
assignment which required extensive developmental effort. This has been perfected to a reliable procedure which accurately denotes ash level within the gasifier (see Section 5.1.4).

- Development of a stirrer internal torque measurement technique to determine the resistance imposed on the stirrer arm inside the gasifier. Accurate measurement of actual stirrer torque will allow detailed information on the resistance of the reactor bed separated from the seals, bearings, etc. This information can be used to provide design data for other systems.

- Fabrication of a ramp-rate generator for implementation of transient analysis studies. The ramp-rate generator is used to provide a smooth set point change at a fixed rate in a process variable. This relieves the operator of the responsibility for manually adjusting a controller meticulously between two set points. The smooth ramp provides a cleaner input signal for subsequent data analysis.

\subsection{ENVIRONMENTAL HEALTH AND SAFETY (EH\&S) RESEARCH}

The commercial acceptability of coal gasification technology mandates that plants operate in a manner that jeopardize neither the health and safety of the worker nor the environment of the surrounding area. DOE has a responsibility to identify and characterize those effluents and emissions that pose hazards to the worker and the environment. Once such parameters have been identified, corrective engineering designs, if necessary, can be implemented and tested. An active R\&D program exists at METC in the area of environmental management and workplace health and safety. Activities related to the fixedbed gasifier and FFCUS have increased significantly since 1979 (Test Run 95). Information acquired for on-site EH\&S compliance also complements process R\&D characterization efforts. The following discussion describes these EH\&S activities. Results from these programs are included in Section 5.4.1.

\subsubsection{Environmental Characterization and Systems Analysis}

The METC system provides an excellent opportunity to conduct environmental research related to pollutant production, characterization, and environmental control technologies. Ongoing projects include:

- Environmental characterization of process streams for air-blown gasification of coal and briquettes and for oxygen-blown coal gasification.

- Development of mass balances around selected unit operations and the overall system for environmentally significant species.

- Development of thermodynamic data, reaction kinetics, and mass transfer coefficients for environmentaliy significant species.

- Identification, characterization, and estimation of fugitive emissions.

- Development of data in support of environmental systems analyses and modeling (models for environmental control and for vapor-liquid/ liquid-ionic equilibrial. 
- Environmental characterization of the Stretford system.

- Comparative analyses of the METC "dry-tar" and conventional delugequench processes.

- Wastewater characterization and ageing studies.

- Joint data development with on-site environmental compliance activities.

Environmental Characterization and Mass Balances. In order to understand both the production and distribution characteristics of pollutants related to fixed-bed gasification, environmental characterization has been performed in streams that are internal to the process. These streams do not actually discharge into the environment, but environmental analysis of these process stream samples yields useful insight into control technology needs. To date, this effort has been restricted to air-blown coal gasification, but will encompass air-blown gasification of briquettes and oxygen-blown operation. Compilation of these characteristics requires combining detailed overall heat and mass balances with comprehensive environmental characterization information. This combination of stream flowrates and pollutant concentrations provides definitive information on distribution patterns for respective pollutants, and also an estimation of environmental. loadings in the wastewater, gaseous, solid, and heavy hydrocarbon liquids streams. The degree of closure of mass balances al so provides a measure of data integrity. Calculations of normalized pollutant production estimates (pounds of pollutant/ton of moisture and ash free or MAF coal) are performed to provide a meaningful basis for comparison of these data with those from other facilities. In order to better understand the basis of pollutant production and distributian, environmental characterization data and mass balances must be augmented by the development of thermodynamic parameters (distribution coefficients, reaction kinetics information, and other rate effects). Inis is in addition to the normal overall process data available from the system provided by ADACS.

The fundamentals of $\mathrm{H}_{2} \mathrm{~S}$ absorption and Stretford liquor chemical interactions that convert the absorbed $\mathrm{H}_{2} \mathrm{~S}$ (or $\mathrm{HS}^{-}$ion) to elemental sulfur are not well understood. Work is underway to study these reactions in detail and to assess the basic role of vanadium, $A D A$, and chelating agents in the Stretford liquor. In addition, the disposal and recycle options for spent Stretford liquor will be investigated.

Additional R\&D projects fall in the area of wastewater ageing studies, identification of previously undetected compounds (e.g., hydantoins), development of advanced environmental sampling and analytical techniques, and joint data development with on-site compliance programs. In keeping with the overall engineering theme of this document, detailed reports on the above activities are published separately. A summary description of results is included in Section 5.4.1.

Environmental Systems Analysis. Computer modeling tools are being developed to assist environmental systems analysis. They require actual pollutant production and distribution data for validation and improvement. The METC system provides the information for developing certain model parameters and 
also provides a data base against which models developed elsewhere can be validated. An example of this is the input into the ASPEN simulation of the METC fixed-bed gasification system. The simulation is complete in that both process and environmental information are included. This detailed environmental characterization yields data for the validation of electrolyte simulation capability in ASPEN, which enables modeling of ions in the liquid phase along with molecules in the vapor and liquid phases. Such information is then useful for simulating environmental control unit operations. A synopsis of these results is given in Table 39 and in Figure 26.

\subsubsection{Byproduct Characterization and Environmental Management}

Gaseous, aqueous, and solid products of the gasifier are characterized to determine their potential impact on the environment. Through process-related monitoring, gas composition and quantity of gas released to the environment are determined. Ambient air monitors, located upwind and downwind of METC, have been sited using approved dispersion modeling techniques in order to measure the impact of gaseous emissions on ambient air quality. Criteria pollutants are continuously monitored.

Gasification wastewater is generated through two major sources: process condensate and ash quench water. Each stream has been characterized to determine the principal components significant in treating these wastewaters. Monitoring efforts at the gasifier, initiated with Test Run 96, have provided data used to define influent water quality parameters. These parameters will be used in the design of a wastewater treatment system at the METC site, scheduled for construction in FY84. Unit operations will include equalization, ammonia stripping, solvent extraction, activated sludge biological treatment, and metals coagulation and sedimentation.

Solid byproducts from the gasification system include bottom ash, devolatilized coal dust, light oils, liquid tars, solid tars, and sulfur. Each byproduct stream has been characterized for toxicity, as defined by the RCRA. Process-related information (such as viscosity and boiling point) has been coupled with data acquired from toxicity tests required by EPA (EP for metals, ignitability, corrosivity, and reactivity) in order to determine the toxicity of solid byproducts from the METC gasifier. Results are illustrated in Section 5.4.1. Solid waste management techniques have been implemented to maximize recovery of the byproducts for re-use or sale. Non-salable byproducts are treated as potentially hazardous materials and are handled accordingly.

\subsubsection{Workplace Health And Safety}

The major goal of the health and safety program is to characterize and quantify material hazards associated with the operation of a synthetic fuels facility. Once hazards have been quantified, appropriate administrative or engineering controls can be implemented in order to minimize these hazards. To determine the exposure effects on workers during the operation of the gasifier, medical personnel have conducted periodic blood and urine sampling and testing. Area testing for carbon monoxide and hydrogen sulfide is regularly conducted to identify potentially hazardous locations. 
A health hazard assessment (HHAS) was conducted in order to: provide a profile of the IMETC gasifier workplace environment for comparison with occpational safety and health standards; determine the chronic and acute occupational health effects related to the METC gasifier operation; and to help create a data base of potential contaminants found at coal conversion facilities of this type. The HHAS was initiated by METC during gasifier Test Run 96. Because of the expertise acquired by NIOSH in performing HHAS at other coal conversion facilities, METC requested that NIOSH participate in the effort at METC.

\subsection{CHEMICAL ANALYSIS DATA BASE}

The operation of the METC fixed-bed gasifier and FFCUS provides a laboratory for the gathering of a chemical process data base for characterization of the process streams. 'Design of gasification plants has generally been hampered by a lack of knowledge on the disposition of trace materials from the feed coals processed in the gasification facility. This was not a problem in past years when raw gas was directly fired in crude equipment and untreated waste water was dumped into sewer systems or directly into nearby streams. Today's designer requires far more data in order to properly design waste treatment systems, and the high-technology potential end uses of the gas (i.e., turbines and fuel cells) are far more sensitive to impurities.

Sampling and analysis of a gasification stream is a complex task, and requires the development of new equipment that can reliably measure the components of the gas stream. The METC program has provided a ready location for the development of sampling techniques and new analytical equipment. Work on these programs has been a cooperative effort by experienced analytical personnel working at METC with outside research organizations. Several of the programs developed include:

- In-house process stream characterization studies.

- Atomic emission analysis studies for alkali and heavy metals in the gas phase.

High- and low-temperature aerosol analysis.

Coherent Anti-Stokes Raman Spectroscopy (CARS) for direct measurement of gas composition in hot and dirty streams such as the gasifier raw product gas stream.

- Laser-Induced Breakdown Spectroscopy (LIBS) for direct measurements of clean gas streams, such as the final product gas.

Results from these activities have been used where applicable for analysis of system performance. A description of the results obtained from these analyzers is presented in section 5.4.2. The concentrations of environmental species are given in Section 5.4.1. 


\subsection{TEST SAMPLES FOR OTHER PROGRAMS}

Many programs funded by the government and/or industry deal with the utilization of product gas, component testing, and disposition and treatment of waste/byproduct streams associated with coal gasification facilities. R\&D such as these require adequate amounts of suitable materials upon which to conduct tests. The operation of the gasifier and FFCUS provides a ready source of material exhibiting the characteristics of actual coal gasifier operation which cannot be synthesized in a laboratory.

The disposition and treatment of streams emanating from gasification facilities has been an area of concern regarding the commercialization of many proposed gasification facilities. The development of new techniques for treating these streams, using samples from the METC gasifier and cleanup system, may provide improvements in these areas.

\subsection{VALVE TEST PROGRAM}

The gasification and valve testing programs have co-existed for several years to the mutual benefit of each program. METC maintains a program to test and develop valves, obtained from various manufacturers, suitable for withstanding the harsh environments associated with coal gasification and combustion processes. Selected valves which have been successfully screened under this program are utilized on the fixed-bed gasifier and FFCUS. This provides useful feedback on the working life of these valves in actual, non-simulated environments. Counters have been installed that track the number of cycles undergone by the coal and ash lock valves. This assists in the development of a wider data base for "mean time between failure" analyses.

Lockhopper valves currently used on the gasifier are Kaymr 10-inch ball valves. These are designed as a class 300,316 stainless steel body, flame spray coated ball, with stellite seats, rated at 720 psig at $650^{\circ} \mathrm{F}$. Typical life experienced by these valves is 4500 cycles. The most common failure is scoring of the bail and seats which results in a failure to hold pressure. Data from the valve test program pertinent to the fixed-bed gasifier are given in Section 5.4.4.

\subsection{COMPUTER-AIDED PROCESS MODELING AND SIMULATION}

Computer-aided modeling of unit operations and process simulation of the overall integrated system play a key role in the overall fixed-bed gasification test program at METC, especially during Phase IV and beyond, when mechanical operational problems have essentially been overcome and the system can be used to extract process characterization information. The simulation can be performed for both steady-state and dynamic modes. The complexity of unit operation models can range from simple "black-box" models to fairly detailed, first-principle models that are usually quite large and require considerable computer resources. The current emphasis is on steady-state simulation. Most of the unit nperation models are at a level of sophistication above the black- 
box category. These models tend to be predictive in nature within the operating range of the gasifier. ASPEN, the most-often used process simulator, is a third-generation process simulator developed especially for coal conversion processes. It was developed at the Massachusets Institute of Technology (MIT) under the aegis of DOE and is the current state-of-the-art for this type of computer program. Both industrial and government users of ASPEN indicate that while ASPEN is a very useful and sophisticated tool, it still needs final "polishing" and debugging, which can best be achieved by attempting to correlate ASPEN with actual process data. Thus, the relationship of ASPEN with METC's fixed-bed gasification program is symbiotic. ASPEN is enhanced by comparing its predictions to actual facility data; system operation is in turn supported by ASPEN in the determination of future operating regimes most valuable for process characterization. The same philosophy can be extended to individual unit operation models of the fixed-bed gasifier, humidifier, Stretford system, and the direct cooler. A discussion of the results of the simulation activities is described in Section 5.4.3.

\subsection{CORROSION/EROSION TEST PROGRAM}

The clean fuel gas produced by the gasifier and cleanup system was utilized by the Corrosion/Erosion Test Facility during Test Runs 95 through 98 . The purpose of this facility was to determine the effects of cleaned, coal-derived fuel gas combustion products on the mechanical properties of candidate ceramic gas turbine components.

The Ceramic Corrosion/Erosion Studies were part of the DOE High-Temperature Turbine Technology Program. The Program's overall goal has been to advance the firing temperatures of gas turbines from the current range of $1900-2000^{\circ} \mathrm{F}$ to the range of $2600-3000^{\circ} \mathrm{F}$. For these exposure tests, relatively clean, low-Btu gas was taken at the end of the METC FFCUS. A sketch of this facility is shown in Figure 14.

Two test units, a "dynamic" and a "static" facility, were designed and fabricated and were operated simultaneously, exposing ceramic materials to the combustion products of the coal-derived gas. Ihe tacilities were designed to burn a common low-Btu fuel gas in a controlied manner. The dynamic facility operated at a temperature of $2600^{\circ} \mathrm{F}$ and produced a combustion product gas velocity of 1000 feet per second $(\mathrm{ft} / \mathrm{sec})$ for a scheduled 1000 hours. The static facility operated three parallel test cells each at selected temperatures $\left(2600^{\circ} \mathrm{F}, 2200^{\circ} \mathrm{F}\right.$, and $\left.1850^{\circ} \mathrm{F}\right)$ for three time durations $(100,300$, and 1,000 hours) at relatively "zero" combustion product gas velocity.

The dynamic test provided an indication of the combined corrosive/erosive effects while the static test provided indications of the predominantiy corrosive effects. By comparing these tests, a measure of each effect on the ceramic specimens could be made. At a minimum, the tests were designed to eliminate materials unsuitable for a coal-derived combustion gas environment. Although follow-up tests may be needed, these studies were intended to identify the degradation of ceramics due to their exposure in a coal-derived gas combustion environment, and to provide input to a ceramic materials technology base for future stationary gas turbines. The results of these tests are described in Section 5.4.5. 


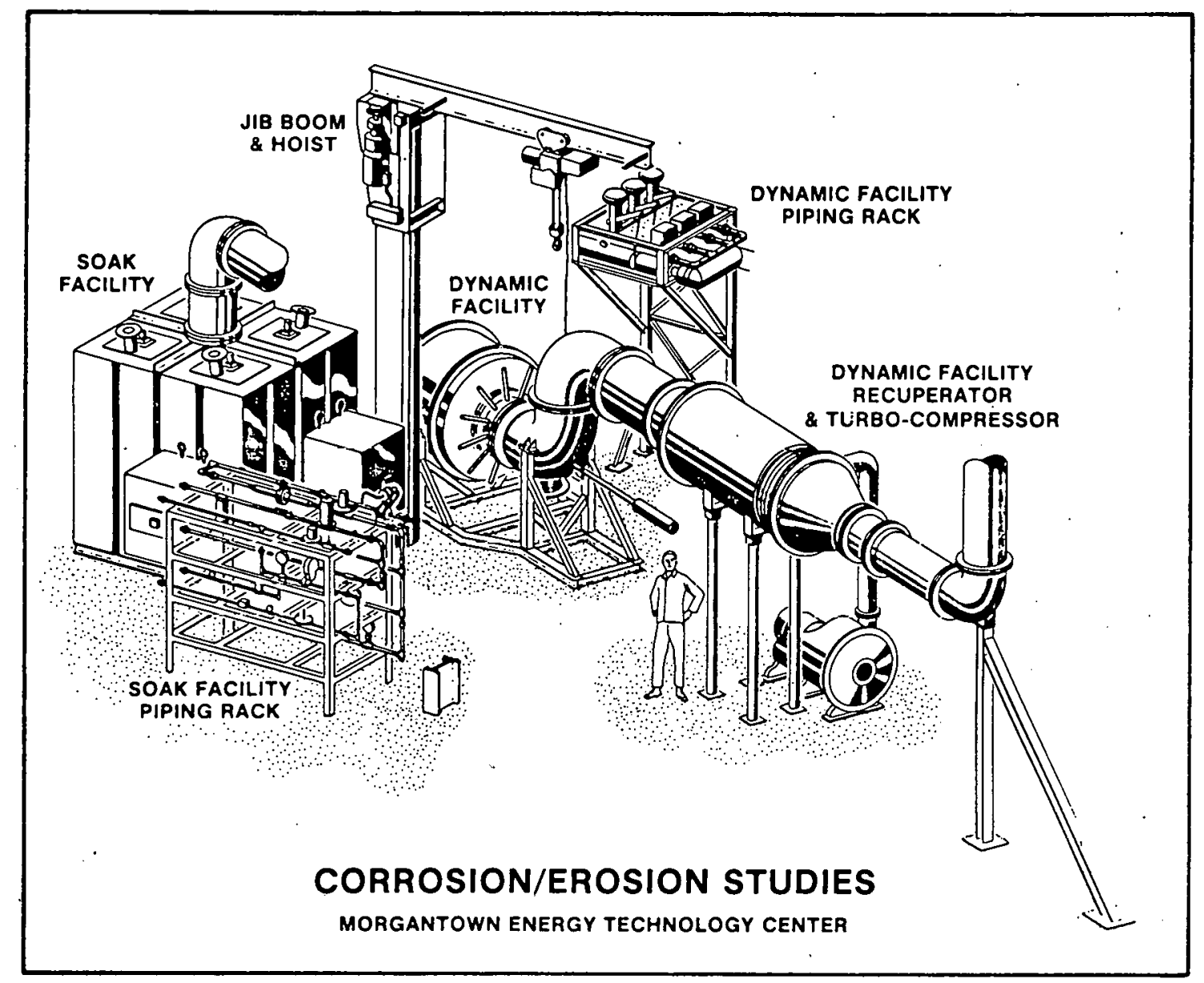

FIGURE 14. CORROSION/EROSION TEST FACILITY 
During Test Runs 96 through 98, the gasifier and cleanup system provided the Corrosion/Erosion Facility with a steady supply of clean, low-Btu gas for each phase of the Test Program. The fuel gas heating value as measured by the on-line calorimeter indicated a consistent range of gas quality values of 175 $\pm 10 \mathrm{Btu} / \mathrm{SCF}$ for the 1000 hours of testing.

\subsection{DISCUSSION OF RESULTS}

The development of the METC fixed-bed gasifier and cleanup system was built upon the experience gained during each phase of the test program. ,This section of the report presents the results of each phase of testing and describes the evaluation of the system components from their initial installation to their present configuration. The improvements performed on the hardware during the course of development have made the METC fixed-bed gasifier and cleanup system into a highly reliable test unit capable of operating during sustained periods. This has prompted use of this system as a field laboratory for additional activities such as development of advanced analytical on-line analyzers and collection of baseline environmental health and safety data. The results of the work from these and other complementary programs are described in Section 5.4.

\subsection{GASIFIER SYSTEM DEVELOPMENT}

The initial testing phase of the gasifier development program took place from December 1967 to May 1976. The test configuration is shown in Figure 15. The auxiliary steam and air supply systems are not shown. Air was supplied at $200^{\circ} \mathrm{F}$, and steam was provided at $400^{\circ} \mathrm{F}\left(75^{\circ} \mathrm{F}\right.$ superheat). During this period, the only gas cleaning component used was the cyclone dust separator. The development and test program focused on checking out the gasifier, demonstrating operation at pressure on highly-caking coals, and generating basic performance data on the broad spectrum of U. S. coals.

During this period 81 test runs were made; useful performance data were gathered in all but six of these. A major objective of these test runs was to improve the reliability of the gasifier. The gasifier operated at pressure levels ranging from near-atmospheric to 300 psig. Although sized cual wds normally used, a crushed run-ot-mine coal was also tested in the gasifler. The gasifier operated on a complete range of U.S. coal feeds from lignite to anthracite, including highly-caking coals such as Pittsburgh No. 8 and Upper Freeport. This Section includes a summary of these data, comparing the primary process data from a cross section of the test runs. Table 3 presents analyses of the coals tested. The gasifier performance was least satisfactory when operated on the North Dakota lignite. Lignite possesses an extremely fragile structure; severe decrepitation of the coal was experienced, and large amounts of dust were entrained in the raw, low-Btu gas. A total of 4,626 operational hours were logged by the pilot plant during Phase I of the test progran!l. 


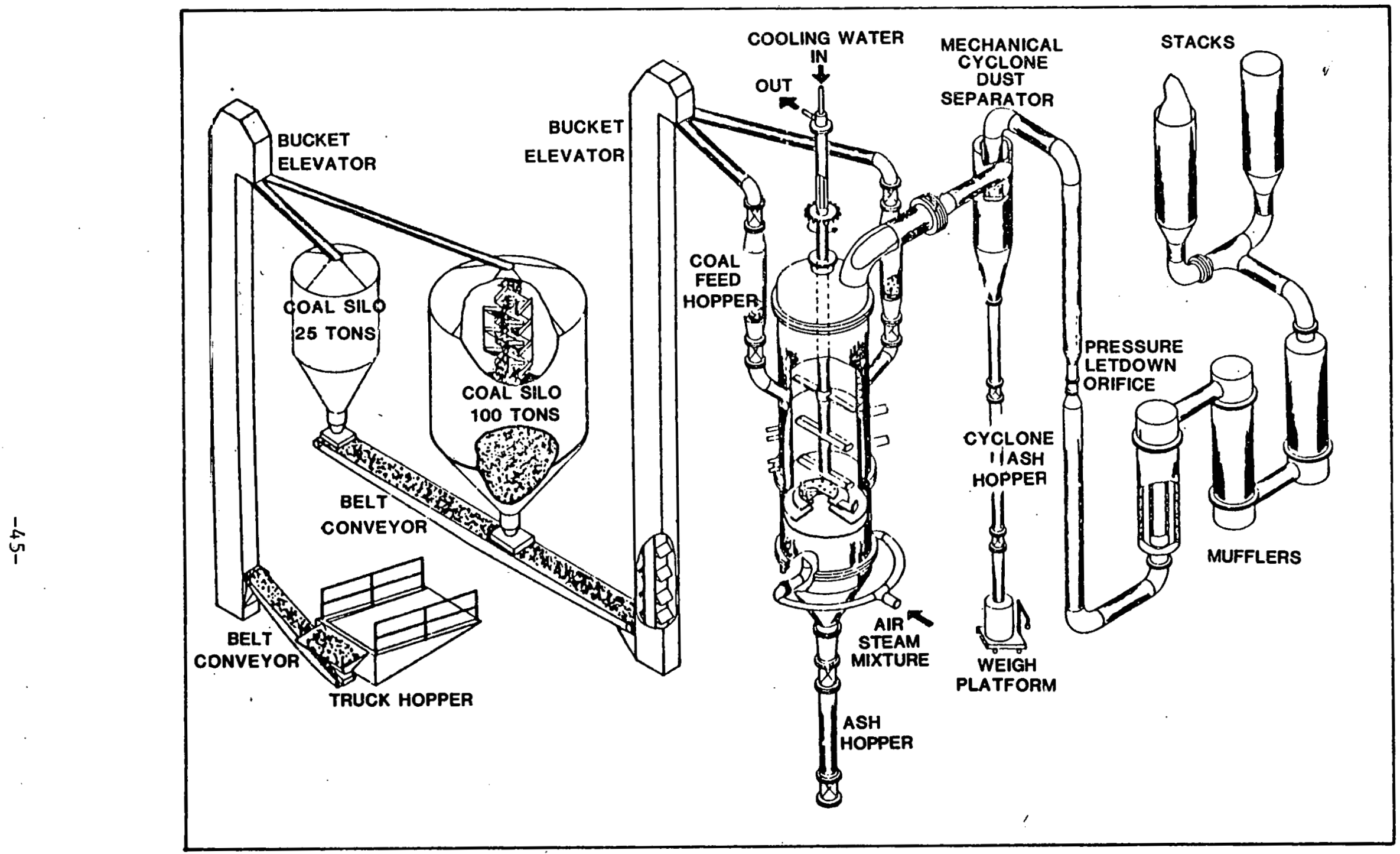

FIGURE 15. GASIFIER TEST CONFIGURATION - PHASE I 
TABLE 3. PHASE I OF TEST PROGRAM-ANALYSES OF COALS TESTED

\begin{tabular}{|c|c|c|c|c|c|c|c|c|c|c|c|c|}
\hline \multirow[b]{2}{*}{ Analysis, percent } & \multirow{2}{*}{$\begin{array}{l}\text { Non-Caking } \\
\text { Anthracite }\end{array}$} & \multicolumn{3}{|c|}{ Low Caking } & \multicolumn{3}{|c|}{ Mediun Caking } & \multicolumn{5}{|c|}{ High Caking } \\
\hline & & \begin{tabular}{|l} 
R.o. \\
Lignite
\end{tabular} & N.M. & $\begin{array}{l}\text { Montana } \\
\text { Rosebud }\end{array}$ & $111 . \$ 6$ & my. 19 & on. 3 & $\begin{array}{c}\text { L. Cedar } \\
\text { Grove }\end{array}$ & $\begin{array}{l}\text { Middle } \\
\text { Kittann. }\end{array}$ & $\begin{array}{l}\text { Pittsburo } \\
\text { Loveridge }\end{array}$ & $\begin{array}{l}\text { gh Seam } \\
\text { Arkwright }\end{array}$ & $\begin{array}{l}\text { Upper } \\
\text { Freeport }\end{array}$ \\
\hline UItimate: & & & & & & & & & & & & \\
\hline $\begin{array}{l}\text { Carbon } \\
\text { Mydrogen } \\
\text { Nitrogen } \\
\text { Sul fur } \\
\text { Oxygen } \\
\text { Ash }\end{array}$ & $\begin{array}{r}85.0 \\
2.0 \\
1.0 \\
.5 \\
.5 \\
10.0\end{array}$ & $\begin{array}{r}41.1 \\
6.9 \\
.6 \\
.7 \\
44.5 \\
6.2\end{array}$ & $\begin{array}{r}50.8 \\
5.1 \\
1.6 \\
1.0 \\
8.5 \\
24.2\end{array}$ & $\begin{array}{r}52.2 \\
6.1 \\
0.8 \\
0.8 \\
32.6 \\
7.5\end{array}$ & $\begin{array}{r}65.7 \\
4.8 \\
1.7 \\
3.7 \\
12.9 \\
11.2\end{array}$ & $\begin{array}{r}64.5 \\
5.5 \\
1.7 \\
3.9 \\
4.0 \\
15.4\end{array}$ & $\begin{aligned} 70.3 \\
5.0 \\
-1.1 \\
4.3 \\
11.2 \\
8.1\end{aligned}$ & $\begin{array}{r}80.9 \\
5.2 \\
1.4 \\
.7 \\
6.2 \\
3.7\end{array}$ & $\begin{array}{r}79.4 \\
5.7 \\
1.3 \\
1.1 \\
2.2 \\
8.3\end{array}$ & $\begin{array}{r}74.2 \\
5.7 \\
1.4 \\
2.9 \\
3.0 \\
7.5\end{array}$ & $\begin{array}{r}75.9 \\
5.7 \\
1.4 \\
2.7 \\
4.9 \\
8.3\end{array}$ & $\begin{array}{r}66.8 \\
4.4 \\
1.2 \\
3.8 \\
2.5 \\
20.3\end{array}$ \\
\hline Proximate: & & & & & & & & & & & & \\
\hline $\begin{array}{l}\text { Molsture } \\
\text { Yolatile Matter } \\
\text { Fixed Carbon } \\
\text { Ash }\end{array}$ & $\begin{array}{r}1.0 \\
4.9 \\
84.1 \\
10.0\end{array}$ & $\begin{array}{r}36.7 \\
26.6 \\
30.5 \\
6.2\end{array}$ & $\begin{array}{r}8.8 \\
31.3 \\
35.7 \\
24.2\end{array}$ & $\begin{array}{r}24.3 \\
28.6 \\
39.6 \\
7.5\end{array}$ & $\begin{array}{r}5.2 \\
36.1 \\
47.5 \\
11.2\end{array}$ & $\begin{array}{l}5.0 \\
34.0 \\
15.6 \\
15.4\end{array}$ & $\begin{array}{r}4.3 \\
40.2 \\
47.4 \\
8.1\end{array}$ & $\begin{array}{r}1.9 \\
34.7 \\
59.7 \\
3.7\end{array}$ & $\begin{array}{r}2.0 \\
29.1 \\
60.6 \\
8.3\end{array}$ & $\begin{array}{r}5.3 \\
35.1 \\
52.1 \\
7.5\end{array}$ & $\begin{array}{r}1.1 \\
36.8 \\
53.8 \\
8.3\end{array}$ & $\begin{array}{r}1.0 \\
51.8 \\
26.9 \\
20.3\end{array}$ \\
\hline$B t w / 101$ & 14,305 & 6,890 & 8,900 & 8,945 & 11.750 & 11.450 & 12,900 & 14,375 & 14,000 & 13,755 & 13,675 & 11,590 \\
\hline Fs1 $: 2$ & & 2 & 2 & 2 & $4-1 / 2$ & $4-1 / 2$ & 5 & 7 & 7 & 8 & 8 & $8-1 / 2$ \\
\hline $\begin{array}{l}\text { Ash Fusion Temp.. }{ }^{\circ} \mathrm{F} \\
\text { Initial Deformation } \\
\text { Softent } \mathrm{gg} \text { Point } \\
\text { Fusion oint }\end{array}$ & $\begin{array}{l}2,410 \\
2,520 \\
2,625\end{array}$ & $\begin{array}{l}2,240 \\
2,280 \\
2,320\end{array}$ & $\begin{array}{l}2,510 \\
2,660 \\
2,600\end{array}$ & $\begin{array}{l}2,265 \\
2,285 \\
2,370\end{array}$ & $\begin{array}{l}2,230 \\
2,350 \\
2,440\end{array}$ & $\begin{array}{ll}2 & 080 \\
2 & 165 \\
2 & 280\end{array}$ & $\begin{array}{l}2,135 \\
2,200 \\
2,200\end{array}$ & $\begin{array}{l}2,600 \\
2,675 \\
2,760\end{array}$ & $\begin{array}{l}2,195 \\
2,360 \\
2,490\end{array}$ & $\begin{array}{l}2,150 \\
2,240 \\
2,370\end{array}$ & $\begin{array}{l}2,237 \\
2,345 \\
2,370\end{array}$ & $\begin{array}{l}2,080 \\
2,190 \\
2,240\end{array}$ \\
\hline
\end{tabular}

1. British Thermal Units per pound

2. Free Swelling Index

3. Ash Fusion Temperature = AFT

Ref.: METC/RI-78/12 
Table 4 shows the performance of the gasifier during pressurized operation with various coal feeds, operating pressures, air and steam feed rates, gas yield and compositions, gas heating values, and cold gas efficiencies. The product gas heating value is based on measurement of the gas constituents. The calculated heating value was generally in the range of 130 to $150 \mathrm{Btu} / \mathrm{SCF}$, which is typical of air-blown gasifiers where the dust, tar, and oils are not included in the heating value. The calculated cold gas efficiencies were generally in the range of 60 to 80 percent. These efficiencies are slightly lower than would be expected in commercial-size gasifiers. Due to their smaller size, pilot units inherently demonstrate higher heat losses which are reflected as efficiency penalties. In the case of the METC gasifier, the heat loss to the water-cooled wall was two to three times greater than that assumed for a larger unit. Cold gas efficiency does not credit the sensible heat in the gas stream, or the heating value of the entrained dust, tar, and oil. Making use of these additional heat energies can theoretically raise the overall thermal efficiency of this type of coal conversion system at a commercial size to over 90 percent.

Attempts were made to measure product gas flow directly; however, contaminants in the gas stream frequently fouled the measuring equipment and made this direct measurement unreliable. Consequently, the product gas flow determination was arrived at indirectly by means of a nitrogen balance.

The basis for calculating the nitrogen balance was to total the incoming nitrogen:

$\left(\% \mathrm{~N}_{2}\right.$ in Air $\times$ Air Mass $\left.\mathrm{FlOW}\right)+\left(\% \mathrm{~N}_{2}\right.$ in Coal $\times$ Coal Flow $)=$ Nitrogen Mass Flow

The volumetric flow of air was readily determined from an orifice meter. Coal samples were periodically sampled and analyzed, and coal feed rates were recorded. These items constitute the necessary input data. Outlet gas flow was calculated by first subtracting the weight of nitrogen removed with the ash, dust, tars, etc., and then analyzing the product gas for nitrogen content.

Mass Flow $\mathrm{N}-\mathrm{N}$ in byproducts = Mass Flow Product Gas $\% \mathrm{~N}_{2}$ in product Gas

This procedure should be reasonably accurate, assuming careful sampling and analysis. With the FFCUS in operation, it is now possible to measure the clean, product gas flow directly. This permits a double check on the calculated cold gas efficiency. Also, the installation of an on-line calorimeter in the final product gas line accounts for small quantities of hydrocarbons that are not measured by the on-line gas chromatograph. This provides more accurate determinations of the product gas heating values used in efficiency calculations. The average heating value recorded for recent test runs using Pittsburgh seam coal has been approximately $170 \mathrm{Btu} / \mathrm{SCF}$.

Representative performance data obtained on various coals for atmospheric and pressurized operation during Phase I are given in Table 5. The gas compositions and heating values and the corresponding efficiencies resulting from operation at higher pressure are comparable with low-pressure operation. The key advantages of operating at pressure are the increased throughput and/or reduced component size and cost at equivalent capacity. This increase in throughput with pressure can be seen in Table 5. 
TABLE 4.

PHASE I OF TEST PROGRAM - GASIFIER PERFORMANCE UNDER PRESSURIZED CONDITIONS ON VARIOUS COAL FEEDS

\begin{tabular}{|c|c|c|c|c|c|c|c|c|c|c|c|c|}
\hline \multirow[b]{2}{*}{ Coal } & \multirow{2}{*}{$\begin{array}{l}\text { Lon-Caking } \\
\text { Anthracite: }\end{array}$} & \multicolumn{3}{|c|}{ Low Caking } & \multicolumn{3}{|c|}{ Hedr um Caking } & \multirow{2}{*}{\multicolumn{2}{|c|}{\begin{tabular}{|l|l} 
Ledar & High \\
Grove & Kittann.
\end{tabular}}} & \multicolumn{2}{|l|}{ Cakring } & \multirow[b]{2}{*}{$\begin{array}{l}\text { Upper } \\
\text { Freeport }\end{array}$} \\
\hline & & Lignite & $\begin{array}{c}\text { Mont. } \\
\text { Rosebud/ } \\
\text { Anthracite }\end{array}$ & M.M. & 111.46 & ky. 19 & on. 18 & & & $\begin{array}{l}\text { Pittsburg } \\
\text { Coveridge }\end{array}$ & $\begin{array}{l}\text { gh Sean } \\
\text { hrkwright }\end{array}$ & \\
\hline Pressure, psig & 80 & 80 & 133 & 145 & 144 & 207 & 80 & 80 & 80 & 90 & 144 & 119 \\
\hline $\begin{array}{l}\text { Input, } 1 \mathrm{~b} / \mathrm{hr} 1 \\
\text { Coal } \\
\text { Air } \\
\text { Steam }\end{array}$ & $\begin{array}{r}540 \\
1,991 \\
320\end{array}$ & $\begin{array}{r}985 \\
3,062 \\
505\end{array}$ & $\begin{array}{c}\star \\
1,228 \\
3,733 \\
1,015\end{array}$ & $\begin{array}{r}1,800 \\
4.583 \\
763\end{array}$ & $\begin{array}{r}1,401 \\
3,894 \\
668\end{array}$ & $\begin{array}{r}1.987 \\
5.708 \\
987\end{array}$ & $\begin{array}{r}1.382 \\
4.594 \\
600\end{array}$ & $\begin{array}{r}1,229 \\
4,594 \\
650\end{array}$ & $\begin{array}{r}1,414 \\
4,381 \\
436\end{array}$ & $\begin{array}{r}1,330 \\
4,419 \\
641\end{array}$ & $\begin{array}{r}1.440 \\
4.725 \\
540\end{array}$ & $\begin{array}{r}1,196 \\
4,033 \\
501\end{array}$ \\
\hline $\begin{array}{l}\text { Input Ratios, } 1 \mathrm{~b} / 1 \mathrm{~b} 2 \\
\text { Steam: Coal } \\
\text { Air: Cosi }\end{array}$ & 3.7 & $\begin{array}{r}.5 \\
3.1\end{array}$ & $\begin{array}{r}.8 \\
3.0\end{array}$ & $\begin{array}{r}.4 \\
2.6\end{array}$ & $\begin{array}{r}.5 \\
2.8\end{array}$ & $\begin{array}{r}.5 \\
2.9 \\
\end{array}$ & $\begin{array}{r}.4 \\
3.3\end{array}$ & $\begin{array}{r}.5 \\
3.5\end{array}$ & .3 & $\begin{array}{r}.5 \\
3.3\end{array}$ & $\begin{array}{r}.4 \\
3.3 \\
\end{array}$ & $\begin{array}{r}.4 \\
3.4\end{array}$ \\
\hline $\begin{array}{l}\text { Output, 10/hr } \\
\text { Ash } \\
\text { Cyclcae Dust } \\
\text { Gas } \\
\text { Tar } \\
\text { Hater }\end{array}$ & $\begin{array}{r}76 \\
2,923\end{array}$ & $\begin{array}{r}87 \\
54 \\
5,310\end{array}$ & $\begin{array}{r}86 \\
16 \\
4,879 \\
2\end{array}$ & $\begin{array}{r}330 \\
86 \\
5,784 \\
53 \\
889\end{array}$ & $\begin{array}{r}154 \\
23 \\
4,965 \\
35\end{array}$ & $\begin{array}{r}\cdot \\
243 \\
18 \\
8,096 \\
21 \\
348 \\
\end{array}$ & $\begin{array}{r}105 \\
9 \\
7.460\end{array}$ & $\begin{array}{r}76 \\
15 \\
6,630\end{array}$ & $\begin{array}{r}97 \\
0 \\
5,873 \\
42 \\
462\end{array}$ & $\begin{array}{r}132 \\
20 \\
5,705 \\
52 \\
481\end{array}$ & $\begin{array}{r}105 \\
2 \\
6.193 \\
71 \\
524\end{array}$ & $\begin{array}{r}135 \\
16 \\
5,375 \\
19 \\
182\end{array}$ \\
\hline $\begin{array}{l}\text { Gas rield } \\
\begin{array}{l}\text { MSCFH } \\
\text { SCF } / 16 \text { Coal } \\
\text { as rec. basis }\end{array} \\
\end{array}$ & $\begin{array}{l}38.0 \\
70.4\end{array}$ & . & & $\begin{array}{l}77.7 \\
43.4\end{array}$ & $\begin{array}{l}76.9 \\
54.8\end{array}$ & $\begin{array}{r}101.4 \\
54.4\end{array}$ & $\begin{array}{l}97.0 \\
70.2\end{array}$ & $\begin{array}{l}86.2 \\
70.1\end{array}$ & $\begin{array}{l}86.4 \\
61.1\end{array}$ & $\begin{array}{l}83.2 \\
61.1\end{array}$ & $\begin{array}{l}91.3 \\
63.4\end{array}$ & $\begin{array}{l}74.7 \\
64.7\end{array}$ \\
\hline $\begin{array}{l}\text { Gas Andilysis, Yol. } \\
\mathrm{CO} \\
\mathrm{CO}_{2} \\
\mathrm{H}_{2} \\
\mathrm{H}_{2} \\
\mathrm{CH}_{4} \\
\mathrm{C}_{2} \mathrm{H}_{6} \\
\mathrm{H}_{2} \mathrm{~S} \\
\mathrm{O}_{2}\end{array}$ & $\begin{array}{r}24.7 \\
6.4 \\
53.8 \\
13.4 \\
.9\end{array}$ & \begin{tabular}{r|}
13.4 \\
12.4 \\
58.2 \\
14.7 \\
1.3
\end{tabular} & $\begin{array}{r}15.3 \\
12.9 \\
50.3 \\
16.7 \\
1.7 \\
.0 \\
.2 \\
.0\end{array}$ & $\begin{array}{r}15.3 \\
12.7 \\
59.3 \\
10.7 \\
2.1 \\
.0 \\
.2 \\
.0\end{array}$ & $\begin{array}{r}18.2 \\
10.6 \\
52.3 \\
15.6 \\
2.4 \\
.0 \\
.7 \\
.0\end{array}$ & $\begin{array}{r}18.1 \\
11.0 \\
54.4 \\
13.3 \\
2.0 \\
.2 \\
.9 \\
.1\end{array}$ & $\begin{array}{r}20.4 \\
6.8 \\
54.7 \\
14.0 \\
2.0\end{array}$ & $\begin{array}{r}22.7 \\
6.9 \\
54.7 \\
13.7 \\
1.7\end{array}$ & $\begin{array}{r}22.9 \\
7.7 \\
52.3 \\
14.5 \\
2.4 \\
.2 \\
.1\end{array}$ & $\begin{array}{r}19.8 \\
9.5 \\
52.0 \\
15.8 \\
2.9 \\
.0 \\
.2 \\
. \quad .0\end{array}$ & $\begin{array}{r}21.7 \\
7.8 \\
53.7 \\
11.0 \\
2.8 \\
.0 \\
.5\end{array}$ & $\begin{array}{r}22.5 \\
7.1 \\
53.6 \\
14.0 \\
2.5 \\
.0 \\
.3 \\
.0\end{array}$ \\
\hline $\begin{array}{l}\text { Heating Val ue } \\
\text { Btw/ } / \text { sef }\end{array}$ & 130 & 100 & 132 & 104 & 138 & 128 & 148 & 135 & 149 & 144 & 139 & 142 \\
\hline Cold 6as Efficteacy & 64 & & & 50 & 65 & 57 & 81 & 66 & 65 & 66 & 64 & 17 \\
\hline
\end{tabular}

* Dilited with anthracite for turbine material tests

NOTE: THESE DATA ARE NOT MECESSARILY REPRESENTATIVE OF THE CURRENT OFERATIONAL CONFIGURATION Ref.: METC/RI-78/12
1. Pounds per hour
3. Tho:ssands of Standard Cubic Feet per Hour
2. Pounds per pound
4. Standard Cubic Feet per Pound 
TABLE 5. GASIFICATION PERFORMANCE DATA OPERATING AT ATMOSPHERE AND PRESSURE FOR ASSORTED TEST GOALS

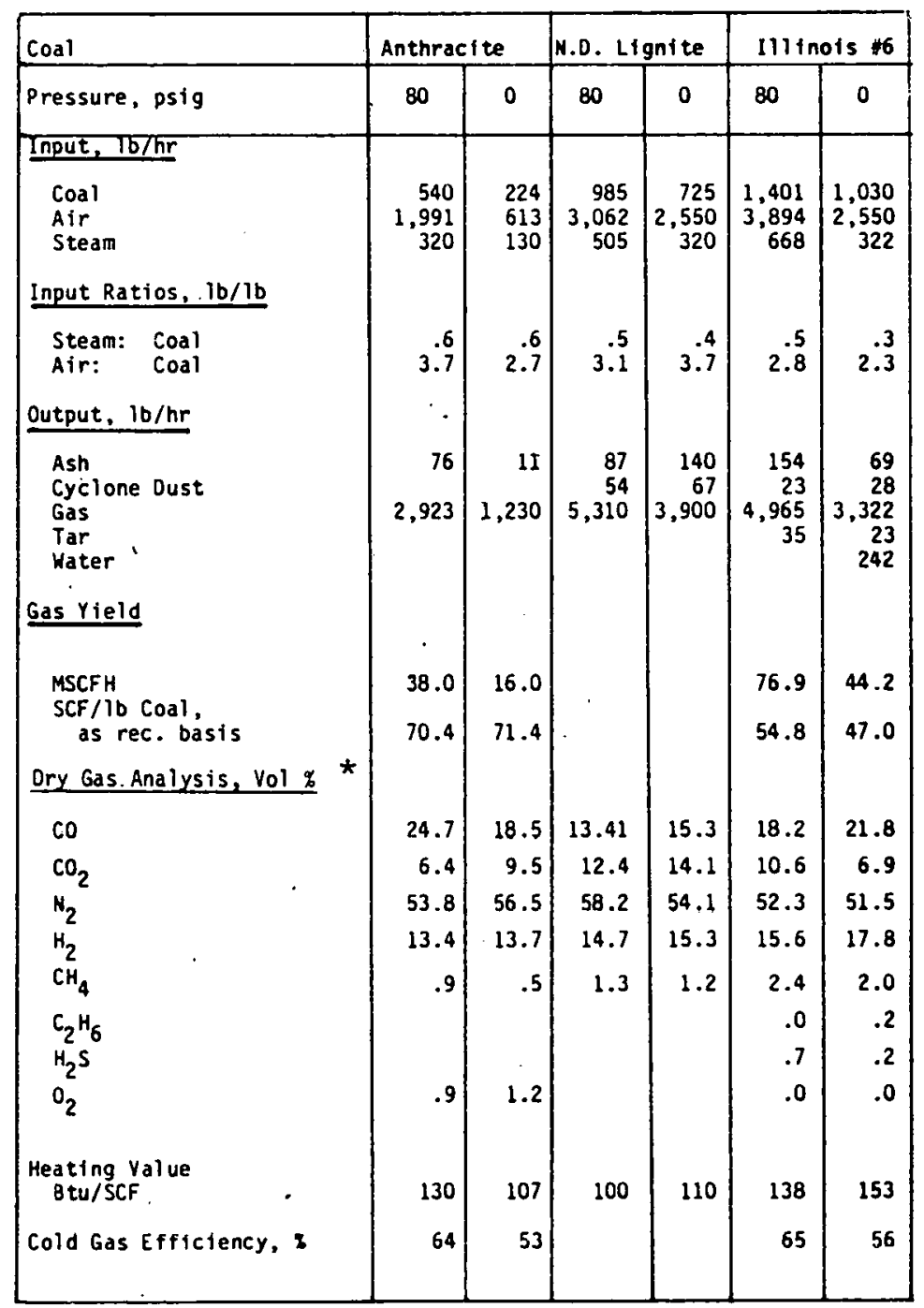

Ref.: METC/RI-78/12

*Volume percent 
In addition to the above performance results, the gasification program has demonstrated and is continuing to develop innovative design and operational concepts that are aimed at improving the reliability and operability of components within the gasification system.

\section{1 .1 Coal Feeding System}

The original design simply used lockhoppers, isolation valves, and gravity to feed coal to the gasifier. When the gasifier required coal, the lower ball valves opened and coal fell down through the feed pipe and into the gasifier. Although inert gas pressurizing was used during coal feeding, feed-system plugging problems were experienced. This was caused by tar condensation and coal caking in the feed pipes and hoppers due to the long residence time of the bituminous coal in the hot environment and occasionally by leaking valves. These problems were corrected by modifying the design as shown in Figure 5 (see Section 3 of this report), to include a rotary feeder and screw feeder in each feed leg. These components feature variable-speed drives and allow for relatively continuous coal feed to the gasifier.

The operation of the coal feed system has been automated to allow "one button" feeding of coal from the storage silos to the gasifier. This system, first tested during Test Run 98, uses a dedicated microprocesser controller to control the operation sequence of the various belts, feeders, bucket elpvators, and valves in the coal feed system. Utilization of this system has promoted more uniform coal feed and allows the operator more time to attend to other factors jaffecting plant operation and performance.

\subsubsection{Bed Level and Voids Sensing}

The McDowell-Wellman gasifier is designed to use poke rods to sense bed levels when operated at atmospheric pressure. This procedure is impractical for measuring bed depth on a pressurized gasifier.

METC has installed and demonstrated nuclear sensing devices based on gamma ray densitometry for measuring and controlling coal level in the pressurized r.nal hoppers and the fixed-bed gasifier. The output of the sensors are utilized as a means to control the coal feeding system. A sketch showing the arrangement of the nuclear sources and detectors is shown in Figure 16. In addition to sensing bed level, the nuclear gauges are also used to monitor bed density in order to detect the occurrence of voids in the bed. The presence of voids in the bed can severely affect gas flow distribution, with detrimental effects on gas production, gas quality, and gasifier efficiency. Once the voids are recognized and located, the condition can be corrected by using the stirrer to break up and redistribute the coal in the bed and reestablish normal operating conditions.

\subsubsection{Bed Stirrer}

The rotating arm or stirrer is essential for operating a fixed-bed gasifier with highly caking coals. The original design used three horizontal arms, two for bed stirring and the top arm for bed leveling; the stirrer cooling water and the gasifier jacket cooling water were a single system. The cooling systems were separated to afford better control and reliability. 


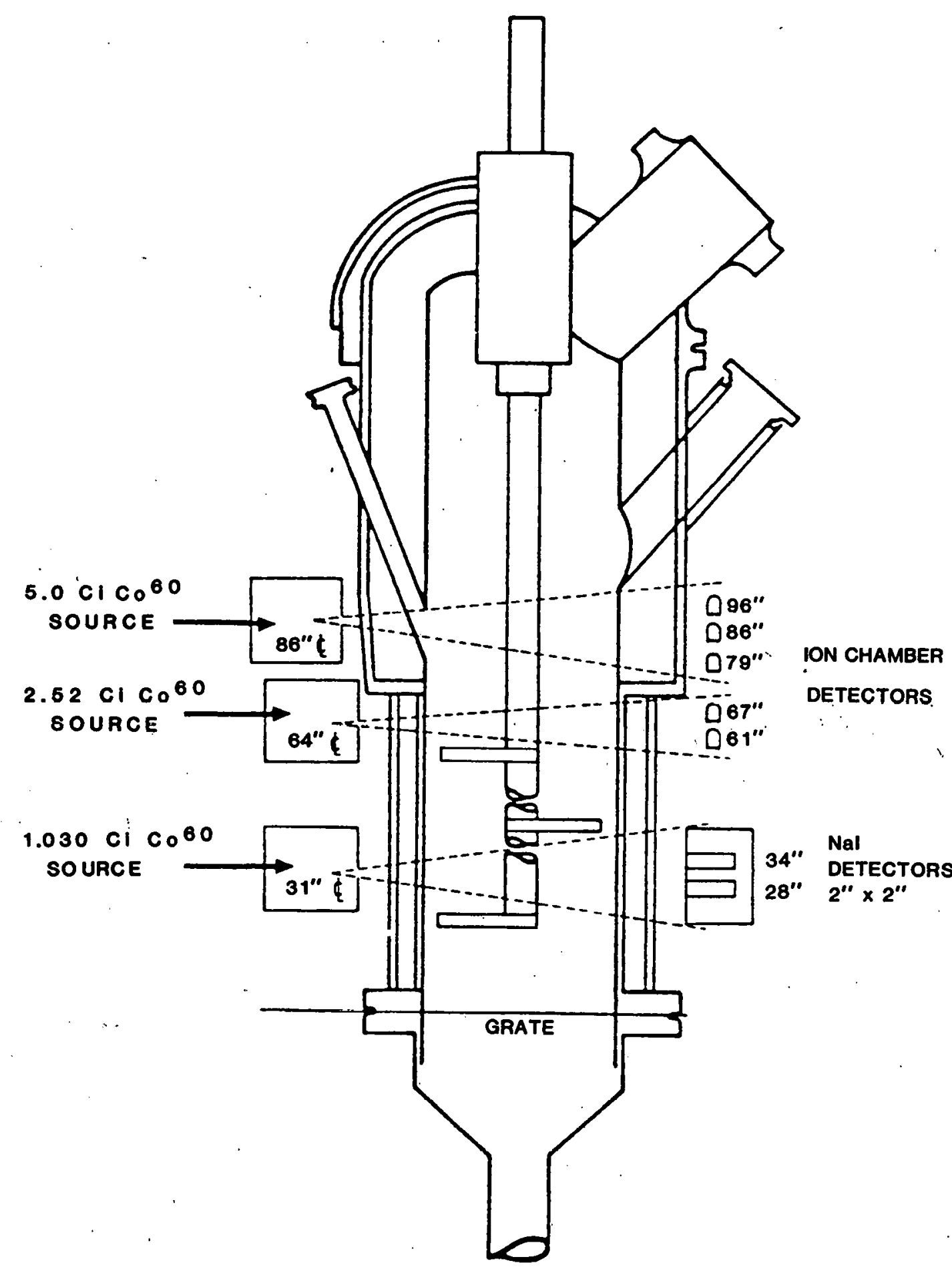

FIGURE 16. METC FIXED-BED GASIFIER - NUCLEAR LEVEL DETECTION DESIGN 
During the past several runs, many improvements have been made in the operation and maintenance of the stirrer and its drive mechanism. The stirrer design, which evolved from three diametral arms to two widely-spaced radial arms, was selected to reduce drag and cooling losses. The principal reason for this change was that the shallow helix angle traversed resulted essentially in overstirring of the bed by the diametral arms. Each arm of the stirrer was equipped with three thermocouples which could indicate bed temperature zones. After approximately 400 hours of testing, inspection of the stirrer revealed that it had become bent. To correct this problem, a subsequent design incorporated a diametral arm at the bottom and maintained the wide spacing and the singular radial upper arm. This design eliminated the unbalanced vertical load and the resultant bending, and was used for 730 hours during Test Run 98. In order to decrease the stirrer vertical cycle time period and al so to increase stirrer effectiveness, a configuration was developed that incorporated three radial arms with reduced vertical spacing. This present array (see Figure 7 in Section 3 of this report), was used successfully in Test Runs 99 and 100. Concurrently with these configuration and operational modifications, abrasion of the arms was al so addressed. Abrasion damage had caused the non-scheduled termination of several tests and accordingly, was of major concern. Each arm of the stirrer is now specially hardened to resist abrasion. A 1/8-inch-thick weld-overlay coating of a mixture of titanium carbide-tungsten carbide-Stellite \#6 powders, specially pre-mixed and carburized, was weld-overiaid on the shaft. Additional treatment involved the application of a diffusion coating of boron carbide. This combination has performed excellently in resisting abrasion and erosion; long-term evaluation is continuing.

The stirrer drive was modified from the original McDowell-Wellman design to a hydraulic mechanism. A hydraulic motor was used to power the rotation and a hydraulic cylinder was used to raise and lower the shaft. A hydraulic power skid provided the motive fluid for the system. The hydraulic system has been much more reliable and trouble-free than the the original mechanical system, which required constant maintenance.

\subsubsection{Grate Temperature Control}

A layer of ash approximately 12 inches deep is used to insulate and protect the metal rotating grate from the hot combustion zone. Measurement and control of the ash layer thickness is accomplished in commercial low-pressure gasifiers by a procedure called rodding or poking. This procedure calls for opening a port in the top of the gasifier and inserting a metal rod through the bed to the grate. The rod is left in place for a given time period, usually five minutes, and is then withdrawn. The location of the combustion zone is readily determined by the cherry-red color of the poking rod, and the distance between the red zone and the end of the rod is the depth of the ash layer. When the ash layer is too shallow, the grate speed is slowed, and conversely, when the layer is too thick, the grate speed is increased. While this poking method is relatively reliable, it is inherently limited to steadystate operations and is unsuited to pressurized operation. It is also unattractive from manpower efficiency and health and safety standpoints. METC 
designed and tested a system whereby thermocouples on and above the grate indicated the adequacy of the ash layer. Several thermocouples were required to provide the necessary area coverage. This arrangement proved unsatisfactory for several reasons. The slow grate motion inherent in normal ash removal precluded the acquisition of sufficient ash-zone temperature data and, as a result, ash-zone depth could not be adequately determined. Subsequent operation also resulted in thermal damage to the thermocouples and grate components.

A superior method of sensing ash zone depth was developed by using data from thermocouples installed in the lower stirrer arm. The temperature spike associated with the combustion zone and subsequent fall in temperature as the stirrer entered the ash zone has been very effectively used to determine ash zone height. The controls and instrumentation have been extended to automatically control grate speed. The thermowells in the arms are of a rugged design which provide extended service within the harsh gasifier environment. The temperature signals are relayed via an FM radio transmitter to facilitate communication between the rotating stirrer shaft and the fixed platform for relay to the control room and ADACS system.

\subsubsection{Grate Drive}

The original grate, supplied by MCDowell-Wellman, was provided with an intermittent electric/mechanical drive mechanism. This design made control of the ash level difficult because it had inadequate speed control. The original mechanism was changed to a continuous hydraulic drive with a wide speed range but also capable of running at low speeds. Greatly improved operation and controlled ash removal rates have been achieved. The hydraulic system powers a cylinder which drives a rack and pinion mechanism. This mechanism transfers the power to the grate drive pinion.

The grate is housed within a device known as the "Bosh ring", which forms a collar around the grate and serves to guide the downward ash flow. Upon examination following a test run, the Bosh ring was often warped or loose. Typically, it would have to be straightened and welded into place prior to the next test run. A new ring was manufactured with slots cut in the sides to allow for thermal expansion. Implementation of this design has eliminated "Bosh ring" problems.

\subsection{SIDE-STREAM CLEANUP SYSTEM TEST RESULTS}

Phase II of the test program consisted of three series of side-stream tests, run in the period from 1975 to 1978. The thrust of the side-stream gas cleanup program was to demonstrate that raw, low-Btu gas generated from highly volatile, highly-caking coal could be cleaned to exacting standards using a novel sequential cleaning approach coupled with conventional gas cleaning technology. The program al so provided operating experience and data for determining the configuration and component designs for the full-flow cleanup train. A preliminary evaluation was made on the effects of actual coalderived fuel gas on gas turbine materials. 


\subsubsection{First Side-Stream Cleanup Test Series}

During the summer of 1976 the side-stream gas cleanup configuration was run initially with Illinois No. 6 coal and later with a mixture of Montana Rosebud and anthracite. Montana Rosebud is a sub-bituminous coal that is easily ${ }^{\circ}$ gasified but presents materials-handling difficulties because of its fine ash properties. The gas heating value is also lower than that obtained with a bituminous coal. For these reasons, Rosebud coal was blended for testing with 25 to 37 percent anthracite to achieve increased heating values of approximately $132 \mathrm{Btu} / \mathrm{SCF}$ (as required for a test series using a gas turbine combustor).

The system configuration, showing locations of material sampling points, is illustrated in Figure 9 (see Section 3 of this report). The scrubbing system operated for 135 hours on gas derived from the Illinois No. 6 coal and 210 hours on gas derived from a mixture of Montana Rosebud and anthracite. The average cleanup system operating pressure for the Illinois No. 6 testing was approximately $80 \mathrm{psig}$ while the Montana Rosebud/anthracite tests were run at approximately 120 psig.

In this first test series, once-through water was used to clean the gas. No attempt was made to recycle the dirty wash liquor. Approximately 20 gallons per minute $(\mathrm{gpm})$ were used to contact the gas at four locations. Up to one gpm was used in the humidifier, $1.5 \mathrm{gpm}$ in the disengagement chamber (tar separator), $9 \mathrm{gpm}$ in the venturi scrubber, and $9 \mathrm{gpm}$ in the valve tray scrubber. The waste water and entrained material from these units were collected in a decanter (see Figure 9). The discharge from the decanter was then pumped into a holding pond for storage, study, testing, and treatment.

The particulates removed from the raw, low-Btu gas stream by the cyclone separator, and the tars and solids collected in the disengagement-chamber lock hopper, were sampled and analyzed. These analyses are presented in Table 6 . Significantly more tars were collected in the Illinois No. 6 bituminous coal tests than in the sub-bituminous/anthraci.te testing.

Table 7 gives the concentrations of contaminants measured in the once-through wash water from both the disengagement chamber and the valve tray separator for Illinois coal.

\subsubsection{Preliminary Gas Turbine Materials Combustion}

The purpose of this series of tests, performed in conjunction with the first series of side-stream tests, was to provide engineering data on the performance of selected gas turbine nozzle and bucket materials in gas environments expected from the combustion of coal-derived low-Btu gas. A turbine simulator test. rig was used which included a fuel combustor, nozzle vane cascade, air-cooled nozzle, and bucket simulation pins. A schematic of the gas turbine simulator is shown in Figure 10 (see Section 3 of this report). The pins contained cooling holes simulating selected cooling air hole sizes, and patterns potentially applicable to airfoil cooling for high-temperature operation. 
TAELE 6. SOLIDS ANALYSIS FROM FIRST SIDE-STREAM TEST SERIES - TEST RUNS 82 TO 84

\begin{tabular}{|c|c|c|c|c|c|c|c|c|c|}
\hline \multirow{2}{*}{\multicolumn{2}{|c|}{ Sampling Point }} & \multicolumn{4}{|c|}{ Illinois No. 6} & \multicolumn{4}{|c|}{ Montana Rosebud/Anthracite } \\
\hline & & Coal & $\begin{array}{l}\text { Bottom } \\
\text { Ash }\end{array}$ & $\begin{array}{c}\text { Entrained } \\
\text { Dust }\end{array}$ & Tar & Coal & $\begin{array}{l}\text { Bottom } \\
\text { Ash }\end{array}$ & $\begin{array}{c}\text { Entrained } \\
\text { Dust }\end{array}$ & Tar \\
\hline \multicolumn{2}{|l|}{ Sampling Point } & 1 & 2 & 3 and 7 & 6 & 1 & 2 & 3 and 7 & 6 \\
\hline Total Carbon & $1 \mathrm{~b} / \mathrm{hr}$ & 903.4 & 25.9 & 16.7 & 27.1 & 804.5 & 11.5 & 9.2 & 1.6 \\
\hline$H$ & $1 \mathrm{~b} / \mathrm{hr}$ & 66.0 & 0.5 & 0.4 & 1.6 & 55.9 & 0.0 & 0.4 & 0.2 \\
\hline$S$ & $1 \mathrm{~b} / \mathrm{hr}$ & 50.9 & 0.8 & 0.5 & 0.9 & 11.0 & 0.2 & 0.2 & 0.0 \\
\hline N & $1 \mathrm{~b} / \mathrm{hr}$ & 15.1 & 0.0 & 0.0 & 0.4 & 9.4 & 0.0 & 0.1 & 0.0 \\
\hline 0 & $1 \mathrm{~b} / \mathrm{hr}$ & 114.1 & 0.0 & 1.0 & 2.4 & 96.1 & 0.0 & 0.0 & .0 .2 \\
\hline Moisture & $\mathrm{lb} / \mathrm{hr}$ & 71.5 & 0.5 & 0.4 & 0.0 & 133.3 & 0.0 & 0.0 & 0.0 \\
\hline Ash & $1 \mathrm{~b} / \mathrm{hr}$ & 154.0 & 126.3. & 4.0 & 2.6 & 119.9 & 74.7 & 6.2 & 0.0 \\
\hline Heating Value & $\mathrm{Btu} / \mathrm{lb}$ & 11,750 & 2,260 & 11,230 & & 11,696 & 1,500 & 9,090 & 14,440 \\
\hline
\end{tabular}

Ref.: METC/RI-78/12 
The gas turbine combustor and the turbine simulator test rig were operated in a series of runs for a total of 144 hours on gas derived from two coal types. Sixty-four hours of combustor operating time were accumulated on Illinois No. 6 coal. The second coal used was a mixture of 63 percent Montana Rosebud and 37 percent anthracite. Eighty hours were logged by the combustor on this mixture. The coals were chosen to include a wide range of sulfur and alkali levels. Illinois No. 6 is a low-sodium, high-sulfur coal while Montana Rosebud is a low-sulfur, high-sodium coal.

The tests were conducted at two atmospheres of combustor pressure. In operation, 800 to 1100 standard cubic feet per hour (SCFH) of natural gas were burned in approximately 100,000 SCFH of air in the preheater to raise the air temperature to $570^{\circ} \mathrm{F}$. The heated air stream was then burned with approximately 28,000 to $33,000 \mathrm{SCFH}$ of cleaned, low-Btu gas to generate a $1750-1830^{\circ} \mathrm{F}$ combustion gas. Table 8 lists the average values for measured emissions in the combustor exhaust. $\mathrm{CO}$ and $\mathrm{HC}$ levels were quite low, indicating satisfactory combustion. No evidence of erosion or corrosion was visible to the naked eye after the 144 hours of operation. The pins were subjected to metallographic examination wich showed penetration of about 1 injl. Although this depth is quite shallow, it was signiticant due to the short operating time and relatively low combustion temperature. This fact, and preliminary analytical evidence of sodium and potassium contaminants in the cleaned, low-Btu gas, indicated that the metal parts of the hot gas path experienced the beginnings of hot corrosion.

\subsubsection{Second Side-Stream Cleanup Test Series}

The second series of side-stream tests were conducted from December 1976 to August 1977. The objectives of the second side-stream cleanup test series were:

- Better control of tar condensation, separation, and removal in the humidifier/disengagement section.

- Recycling and cooling of the wash water to minimize water usage and wastewater treatment requirements.

- Decanting of the wash water under pressurized conditions with a suitable level of separation to allow recycling of the water in the process.

- Determination of alkali metal content in the product gas stream.

- Characterization and quantification of the sulfur compounds in the product gas stream.

To accomplish these objectives, a number of major changes were made in the cleanup system configuration shown in Figure 11 (see Section 3 of this report). The raw, low-Btu gas source to the side stream was relocated downstream of the cyclone separator in order to reduce the particulate loading of the gas input to the humidifier. Second, the system was fitted with a pressurized decanter connected to the scrubber water effluent line. The decanter was designed to separate out low-boiling tars and particulates from the wash 
TABLE 7." CONTAMINANT LEVEL IN ONCE-THROUGH WASH WATER

OPERATING WITH ILLINOIS' NO. 6 COAL - TEST RUNS 82 AND 83

\begin{tabular}{|c|c|c|}
\hline Parameter & $\begin{array}{c}\text { Disengagement } \\
\text { Chamber }\end{array}$ & $\begin{array}{c}\text { Separator to } \\
\text { Decanter }\end{array}$ \\
\hline $\operatorname{COD}(\mathrm{mg} / 1) *$ & 33,250 & 31,250 \\
\hline Phenol $(\mathrm{mg} / \mathrm{l})$ & 3,780 & 930 \\
\hline $\mathrm{NH}_{3} \quad(\mathrm{mg} / 1)$ & 414.8 & 61.2 \\
\hline $\mathrm{CO}_{3} \quad(\mathrm{mg} / 1)$ & 0 & 0 \\
\hline $\mathrm{HCO}_{3} \quad(\mathrm{mg} / \mathrm{l})$ & 1,160 & 1,600 \\
\hline Cl $(\mathrm{mg} / 1)$ & 68.0 & 36.2 \\
\hline $\mathrm{s} \quad(\mathrm{mg} / 1)$ & 4.2 & 3.9 \\
\hline $\operatorname{SCN} \quad(\mathrm{mg} / 1)$ & 10.8 & 6.4 \\
\hline $\mathrm{CN} \quad(\mathrm{mg} / 1)$ & 2.5 & 2.7 \\
\hline $\mathrm{Na}_{2} \mathrm{O} \quad(\mathrm{mg} / 1)$ & 35.3 & 34.2 \\
\hline $\mathrm{K}_{2} \mathrm{O} \quad(\mathrm{mg} / \mathrm{l})$ & 3.6 & 2.7 \\
\hline pH & 8.2 & 6.8 \\
\hline
\end{tabular}

TABLE 8. MEASURED EMISSIONS IN GAS TURBINE SIMULATOR COMBUSTOR EXHAUST - TEST RUNS 82 TO 84

\begin{tabular}{|l|c|c|}
\hline \multirow{2}{*}{ Species } & \multicolumn{2}{|c|}{ Coal Type } \\
\cline { 2 - 3 } & $\begin{array}{c}\text { Illinois } \\
\text { No. } 6\end{array}$ & $\begin{array}{c}\text { Montana Rosebud/ } \\
\text { Anthracite }\end{array}$ \\
\hline Total Hydrocarbons * & $3.5(\mathrm{ppm}) * \star$ & $8.8(\mathrm{ppm})$ \\
CO & $52.8(\mathrm{ppm})$ & $64.5(\mathrm{ppm})$ \\
NO & $13.6(\mathrm{ppm})$ & $10.4(\mathrm{ppm})$ \\
$0_{2}$ & $11.4(\%)$ & $11.2(\%)$ \\
\hline
\end{tabular}

*Measured by continuous gas chromatograph

** parts per million 
water. Pumps for recycling water back to the humidifier, disengagement chamber, and valve tray. scrubber were connected to the water leg. The venturi scrubber was removed from the cleanup train for the remainder of the sidestream test series. Four small indirect water-cooled shell and tube heat exchangers were installed to cool the recycled scrubbing water.

The recycled wash water contained light oils, phenols, and ammonia scrubbed from the producer gas. A bleed stream from the decanter limited the buildup of these constituents to maintain the effectiveness of the recycle-water scrubbing liquor.

A Pittsburgh No. 8 (Arkwright) bituminous coal was used in this and all subsequent test series. This coal has a free swelling index of eight and is typical of highly-caking eastern coals. This coal was selected as a baseline for the cleanup system testing because it was locally available, representative of coals difficult to gasify, heavy in tar production, and high in sulfur. A gasification cleanup system capable of generating clean, low-Btu gas from this coal should be capable of processing most of the coals in the United States.

The results of this test series demonstrated that recycling of scrubbing liquor could be achieved with reasonable operability, and that the liquor could be effectively used to cool and remove tars and oils from the raw, lowBtu gas. Control of humidifier exit temperature was not achieved.

This test series provided a wealth of data. Samples of the major flow streams were taken at periodic intervals. The analyses of samples collected during Test Run 87 (June 1977) are given in the following tables.

Table 9 - Analysis of Pittsburgh No. 8, Arkwright Coal

- Analysis of Bottom Ash

- Analysis of Cyclone Dust

- Analysis of Tar

Table 10 Arialysis ur Ráw Gásifièr Gas

- Analysis of Cleaned Product Gas

- Measured Concéntration of Sulfưr Compounds in Raw and Cleaned Product Gas

Table 11 - Analysis of Recycle and Decanter Liquor

\subsubsection{Third Side-Stream Cleanup Test Series}

This series of tests was primarily designed to determine the equipment requirements for the FFCUS configuration. Two modifications were made to the system:

- A dual-phase (inert gas) nozzle was installed in the humidifier. This nozzle was designed to atomize the scrubbing liquor to droplets one to five microns in size. The objective of this two-phase nozzle test was to improve the controllability of the humidifier exit-gas temperature and to minimize water flow requirements. 
TABLE 9. GASIFICATION DATA, STATISTICAL ANALYSIS OF SIX SAMPLE SAMPLE PERIODS, PITTSBURGH NO. 8-ARKWRIGHT COAL - TEST RUN 87

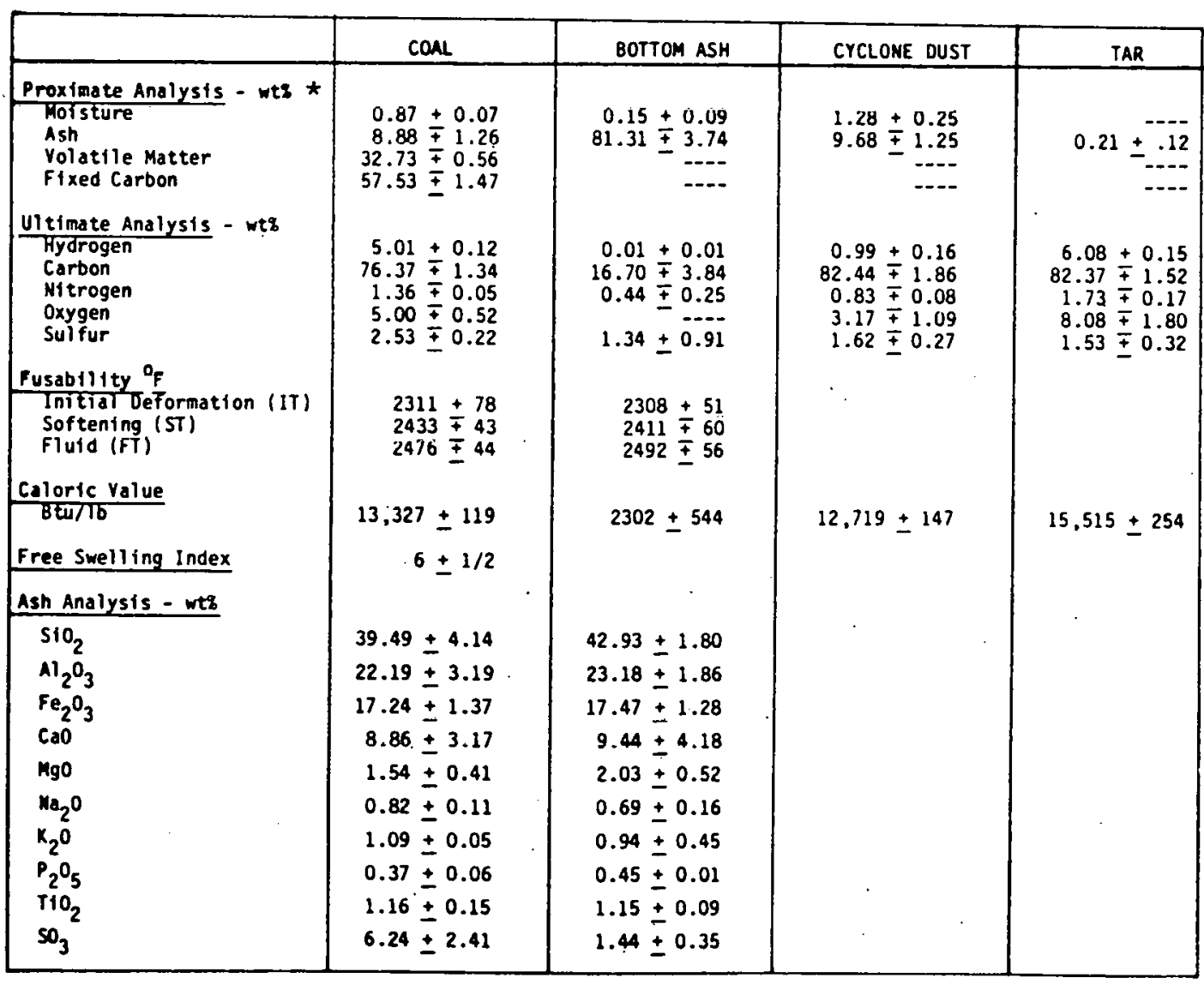

*Weight percent 
TABLE 10. GAS ANALYSIS (AVERAGE OF 5 SAMPLES)-TEST RUN 87

\begin{tabular}{|c|c|c|c|c|}
\hline \multirow[b]{2}{*}{ Species } & \multicolumn{2}{|c|}{ Gas Exiting Cyclone } & \multicolumn{2}{|c|}{$\begin{array}{c}\text { Clean Gas } \\
\text { Exiting Side-Stream }\end{array}$} \\
\hline & On-Line $G C$ & Lab GC & On-Line GC & Lab GC \\
\hline $\mathrm{H}_{2} \quad(\mathrm{vol} \%)$ & $16.74 \pm 0.68$ & $16.58+0.68$ & $16.35+0.50$ & $16.20+0.24$ \\
\hline $\mathrm{CO}_{2}(\mathrm{vol} \%)$ & $8.98 \pm 1.07$ & $9.14 \pm 0.94$ & $8.18 \pm 1.09$ & $7.16 \pm 3.67$ \\
\hline $\mathrm{C}_{2} \mathrm{H}_{6}($ vol \%) & $0.29 \pm 0.03$ & $0.30 \pm 0.07$ & -- & $0.34 \pm 0.08$ \\
\hline $\mathrm{H}_{2} \mathrm{~S}($ vol \%) & $0.40 \pm 0.04$ & $0.39 \pm 0.03$ & $0.40 \pm 0.00$ & $0.35 \pm 0.40$ \\
\hline $\mathrm{N}_{2} \quad(\operatorname{vol} \%)$ & $49.46 \pm 0.75$ & $50.00 \pm 1.04$ & $50.73 \pm 0.49$ & $50.72 \pm 0.54$ \\
\hline $\mathrm{CH}_{4} \quad($ vol \%) & $2.58 \pm 0.61$ & $2.54 \pm 0.59$ & $2.53 \pm 0.22$ & $2.76 \pm 0.21$ \\
\hline CO (vol \%) & $21.30 \pm 1.35$ & $20.46 \pm 0.98$ & $21.35 \pm 1.82$ & $20.52 \pm 1.19$ \\
\hline \multirow[t]{2}{*}{$0_{2} \quad(\operatorname{vn} 7 \%)$} & - & $0.47 \pm 0.09$ & $0.65 \pm 0.08$ & $0.58 \pm 0.08$ \\
\hline & \multicolumn{2}{|c|}{ Gas Exiting Cyclone } & \multicolumn{2}{|c|}{$\begin{array}{l}\text { Clean Gas } \\
\text { Exiting Side-Stream }\end{array}$} \\
\hline Species & \multicolumn{2}{|c|}{ Lab GC } & \multicolumn{2}{|c|}{ Lạb GC } \\
\hline $\cos (p p m \text { vol })^{\star}$ & \multicolumn{2}{|c|}{$190.0 \pm 6.0$} & \multicolumn{2}{|c|}{$187.0 \pm 5.5$} \\
\hline $\mathrm{CH}_{3} \mathrm{SH}$ (ppm vol) & \multicolumn{2}{|c|}{$15.5 \pm 4.5$} & \multicolumn{2}{|c|}{$11.7 \pm 1.6$} \\
\hline $\mathrm{CS}_{2}(\mathrm{ppm}$ vol) & \multicolumn{2}{|c|}{$15.8 \pm 1.0$} & \multicolumn{2}{|c|}{$17.3 \pm 2.4$} \\
\hline Thiophene (ppm vol) & \multicolumn{2}{|c|}{$18.5 \pm 0.8$} & \multicolumn{2}{|c|}{$-22.3 \pm 3.0$} \\
\hline \multirow{2}{*}{\multicolumn{3}{|c|}{ Species }} & \multicolumn{2}{|c|}{$\begin{array}{c}\text { Clean Gas } \\
\text { Exiting Side-Stream }\end{array}$} \\
\hline & & & $\begin{array}{r}\text { Alkdli Melal } \\
\text { Met }\end{array}$ & $\begin{array}{l}\text { by Wet Test } \\
\text { dd }\end{array}$ \\
\hline \multirow{2}{*}{$\begin{array}{l}\mathrm{Na}(p p m w t)^{* \star} \\
K(p p m w t)\end{array}$} & & & $\begin{array}{l}0.37 \\
0.10\end{array}$ & 0.07 \\
\hline & & & 0.10 & 0.07 \\
\hline
\end{tabular}

*Parts per million by volume

**Parts per million by weight 
TABLE 11. ANALYSIS OF RECYCLE AND DECANTOR LIQUORTEST . RUN 87

\begin{tabular}{|l|c|c|c|}
\hline & & $\begin{array}{c}\text { Recycle } \\
\text { Liquor }\end{array}$ & $\begin{array}{c}\text { Decanter } \\
\text { Liquor }\end{array}$ \\
\hline Tar Solids wt\% & & 2.1 & 10.4 \\
\hline Tar-Free Basis: & & & \\
\hline pH & & 8.1 & 8.3 \\
Ammonia (Free) & $\mathrm{mg} / 1$ & 3,658 & 4,740 \\
Bicarbonate & $\mathrm{mg} / 1$ & 11,240 & 9,060 \\
Carbonate & $\mathrm{mg} / 1$ & 3,360 & 4,940 \\
Chloride & $\mathrm{mg} / 1$ & 473 & 391 \\
Cyanide & $\mathrm{mg} / 1$ & 60 & 58 \\
Phenol & $\mathrm{mg} / 1$ & 1,160 & 1,140 \\
Sulfur (total) & $\mathrm{mg} / 1$ & 547 & 550 \\
Sulfide & $\mathrm{mg} / 1$ & 262 & 191 \\
Thiocyanate & $\mathrm{mg} / 1$ & 10 & 10 \\
CoD* & $\mathrm{mg} / 1$ & 56,000 & 44,500 \\
B0D** & $\mathrm{mg} / 1$ & 10,855 & 6,420 \\
\hline
\end{tabular}

*Chemical 0xygen Demand

**Biological Oxygen Demand 
A 20-inch-diameter packed column was added at the tail end of the side-stream cleanup train. The purpose of this unit was to investigate the feasibility of using water to scrub the cleaned, lowBtu gas to remove trace levels of alkali metals.

The two-phase nozzle effectively controlled gas temperature and removed tars. However, further development was needed in order to refine control methods and optimize inert gas pressure and flow requirements. The tar particles condensed in the humidifer did not all separate from the gas stream in the humidifier and disengagement chamber. Some particles were carried into the tray scrubber and caused fouling of tray valves. It was concluded that a much more effective tar separator located after the humidifier would be essential for the FFCUS.

Because of mechanical problems with the scrubbing water feed and some contamination of the packings with carryover tars and oils, the trace alkali-metal scrubber column was not operated long enough to provide meaningful data.

Test samples and analyses made during this series were consistent with the previous tests. A typical sample analysis for the solid; gaseous, and liquor constituents is given in Table 12 .

\subsection{FULL-FLOW CLEANUP SYSTEM TEST RESULTS}

Early testing of the FFCUS was devoted to developing the "dry-tar" removal system and to identifying any unexpected effects from scale-up. The test program was planned to begin with testing and verification of only the upstream components, i.e., the cyclone, humidifier, and tar separator. Once the satisfactory performance of these components was established, the remaining components were installed in the process train for testing and performance verification. Improvements to the gasifier bed-level monitoring, bed-temperature sensing, and total system pressure control were al so tested.

Figure 17 shows the initial components of the full-flow cleanup train configuration used in Test Runs 91 through 93 . All of the raw, low-Btu gas Howed through the dust cyclone, humidifier, and tar separator. After the separator the gas was divided, with the major portion going to the flare and approximately 20 percent going to the side-stream through a tray scrubber, knock-out drum, and alkali metal scrubber, and then being discharged in the flare.

The primary objective of this series of test runs was to establish component configurations and operating conditions that would result in satisfactory removal of the builk of the entrained particulates and heavy tars in the raw, low-Btu gas stream. Once this was accomplished, the downstream components were to be added to the full-flow cleanup train in order to remove the remaining tars, light oils, and sulfur gases, yielding a clean fuel gas suitable for gas turbine and other types of burner testing.

The above test series eventually produced a relatively particulate- and tarfree gas. Many operating problems were experienced, resulting in substantial component and system modifications. 
TABLE 12.

TYPICAL SAMPLE ANALYSIS FROM THE

THIRD SIDE-STREAM TEST SERIES - TEST RUN 90

\begin{tabular}{|l|c|c|c|c|}
\hline Solids, wt & Coal & $\begin{array}{c}\text { Bottom } \\
\text { Ash }\end{array}$ & $\begin{array}{c}\text { Cyclone } \\
\text { Dust }\end{array}$ & Tar \\
\hline Moisture & 1.06 & 0.41 & 0.89 & 0 \\
Ash & 8.01 & 76.51 & 10.34 & 0.22 \\
Sulfur & 2.61 & 0.91 & 1.95 & 1.99 \\
Hydrogen & 5.23 & 0.09 & 1.32 & 6.83 \\
Carbon & 76.36 & 22.00 & 82.92 & 84.35 \\
Nitrogen & 1.47 & 0.08 & 1.38 & 1.56 \\
Oxygen (diff.) & 5.26 & 0 & 0 & 5.05 \\
Heat Content (Btu) & 13.530 & 2,610 & 12,720 & 15,600 \\
\hline
\end{tabular}

\begin{tabular}{|c|c|}
\hline Cyclone Exit Gas & $\frac{\text { Volume q }}{\text { Hydrogen }}$ \\
Carbon monoxide & 16.77 \\
Carbon dioxide & 20.85 \\
Nitrogen & 8.54 \\
Oxygen & 49.57 \\
Methane & 0.69 \\
Ethane & 2.38 \\
Propane & 0.23 \\
Butane & 0.19 \\
Ethylene & 0.09 \\
$\mathrm{H}_{2} \mathrm{~S}$ & 0.13 \\
COS & $3994 \mathrm{ppm}$ \\
$\mathrm{CS}_{2}$ & $241 \mathrm{ppm}$ \\
$\mathrm{NH}_{3}$ & $13 \mathrm{ppm}$ \\
\hline
\end{tabular}

\begin{tabular}{|l|r|}
\hline Scrubbing Liquor & $m g / 1$ \\
\hline Armonia & 3,502 \\
Bicarbonate & 11,310 \\
Carbonate & 1,750 \\
Chloride & 67 \\
Cyanide & 43 \\
Co0 & 54,455 \\
Mardness & 20 \\
Phenol & 30 \\
Suspended Solids & 12 \\
Dissoived Solids & 3,170 \\
Sulfur (total) & 610 \\
Sulfide & 400 \\
Thiocyanate & 15.4 \\
Sodium & 2.8 \\
Potassium & 1.7 \\
pH & 7.85 \\
Alkalinity & 13,060 \\
Tar solids (wt \$) & 1.3 \\
Conductivity ( mho/cm)* & 26,000 \\
Specific Gravity. & 1.0099 \\
\hline
\end{tabular}

mho/ $\mathrm{cm}={ }^{*}$ Conductivity units as mhos per centimeter 


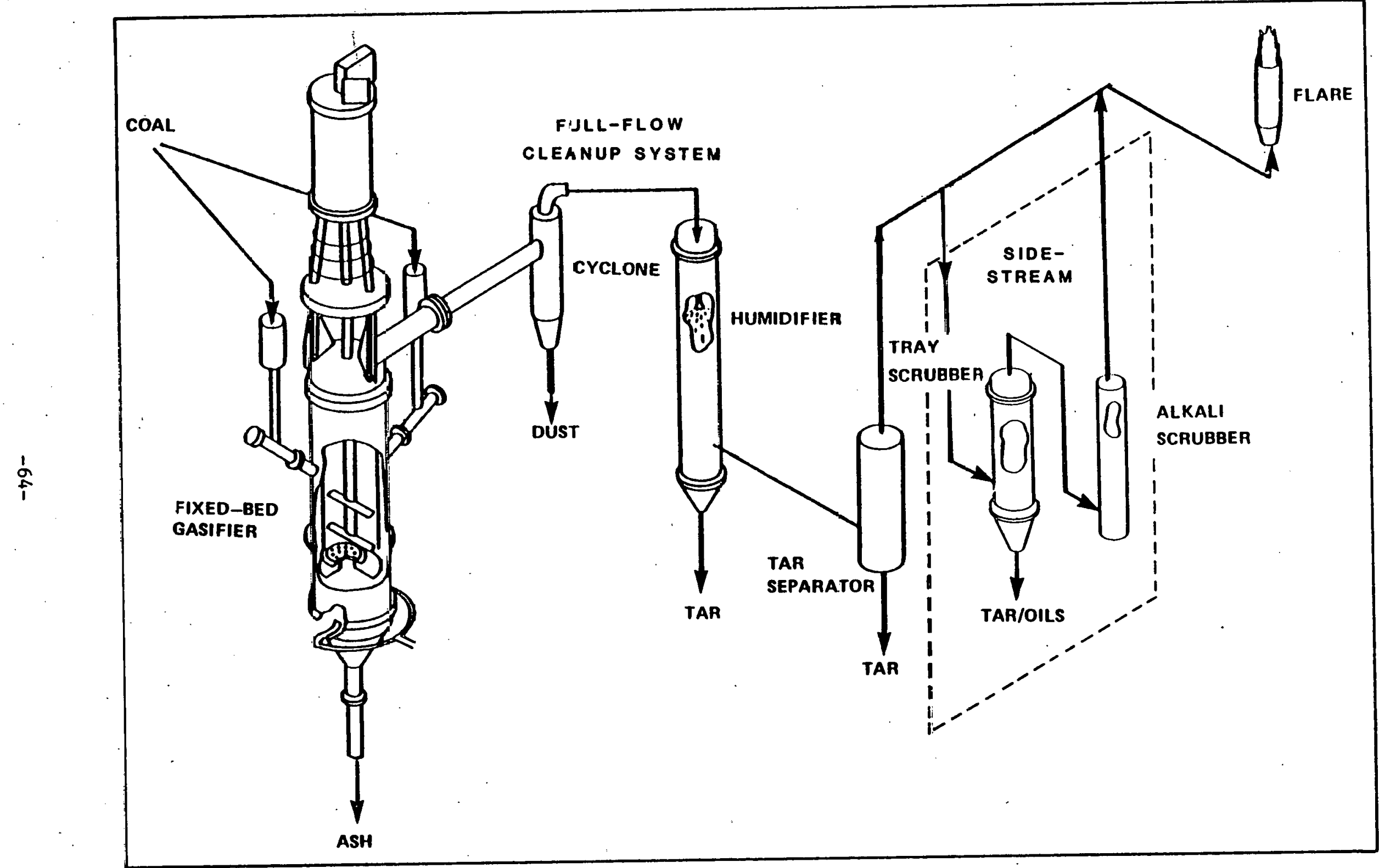

FIGURE 17. INITIAL FULL-FLOW CLEANUP TRAIN CONFIGURATION WITH SILE-STREAM - TEST RUNS 91 TO 93 


\subsubsection{Phase III of the Test Program - Initial Testing of Ful1-Flow Components}

The first new component of the FFCUS to be tested was a new, high-efficiency dust removal cyclone which had been installed for Test Run 91 . This cyclone was a commercially designed and fabricated unit with a predicted capability for 90 percent removal of particles over 5 microns at a gas inlet velocity of $120 \mathrm{ft} / \mathrm{sec}$. Testing during Run 91 was hampered by the rapid erosive failure of this commercial dust cyclone. Erosion at operating velocities of between 115 and $170 \mathrm{ft} / \mathrm{sec}$ experienced during Run 91 was sufficient to result in vessel failure within 24 hours. The cyclone was patched and the testing continued for another day. It was determined that the use of a high-velocity cyclone designed to achieve high removal efficiencies was probably not feasible; it al so appeared to be unnecessary for humidifier and tar separator operability. METC fabricated a new low-velocity cyclone with a design point of $50 \mathrm{ft} / \mathrm{sec}$. This new cyclone provides excellent reliability and adequate dust removal.

The operation of the humidifier and tar trap was to have been the central focus of this series of test runs. Various single-phase and two-phase spray nozzle designs and configurations were tested during this period. The intent of this testing was to identify a nozzle that would provide a high degree of atomization for the small liquid flowrates under consideration (typically 0.5 to $2.5 \mathrm{gpm}$ ). Atomization of the mist to droplets of less than 50 microns was desired to ensure rapid and complete evaporation of the spray water within the confines of the humidifier vessel. Larger droplet sizes require a larger pressure vessel to ensure complete evaporation. To achieve this degree of atomization with single-phase nozzles at these flow rates requires pressuring water through very small holes. It was feared that these nozzles would be prone to plugging when recycle liquor was utilized as a cooling medium. For this reason, two-phase nozzles were investigated.

Finding a two-phase nozzle that would provide a high degree of atomization when operated under a system pressure of 100 to $300 \mathrm{psig}$ was difficult. The two most promising spray nozzles were a two-phase nozzle from Sonic Development Corporation, and a single-phase nozzle from Bete. None of the vendors of commercially available two-phase spray nozzles who were questioned had data or experience with operation under pressurized conditions. Various types of nozzles were tested based on their performance at atmospheric conditions.

Actual performance of the humidifier indicated that under the higher pressure conditions, data did not correlate well with the atmospheric data available, nor did the humidifier lend itself to the normal pressure-ratio scaling laws. Although the two-phase nozzles functioned well, their excessive use of nitrogen as an atomization medium was calculated to be prohibitive in a highpressure, commercial installation. Studies made to determine the economic viability of this type of atomization indicated that the use of cleaned and compressed recycle product gas would be technically feasible in a commercial facility but would add noticeably to the system complexity. As a consequence, emphasis was placed on the single-phase nozzle approach.

Computer models of the humidifier design have been formulated to assist with optimization. Nozzle testing and humidifier development were test objectives for Test Runs 91 through 96. In addition, analysis of humidifier test data 
from Test Run 94 indicated that the vessel was undersized. The length of the vessel was increased from 10 to 30 feet prior to Run 95, in order to provide increased residence time for full droplet evaporation at the design, i.e., of 120,000 SCFH gas throughput at 200 psig. Testing of single-phase nozzles providing droplet size in the 100- to 200-micron range, when a pressure of 200 to 300 psi was applied across the nozzle, determined that liquor would sufficiently evaporate within the vessel. To ensure that the orifice in the nozzle would not plug, filters were provided upstream of each nozzle.

Humidifier operation was considered essential to the operation of the balance of the cleanup system. As a result of testing efforts described earlier, the humidifier is now an effective, reliable cooling device capable of operating in an automatic control mode at the desired operating temperature set points. The humidifier operates reliably and controls gas temperature between 375 and $400^{\circ} \mathrm{F}$. Humidifier data developed during Run 96 closely followed behavior predicted from Run 94 . Table 13 compares analytical results with predicted values.

The humidifier currently uses four Bete single-phase nozzles of differing rapacities. The nozzles resemble spark pluys and are shielded from the incoming raw gas in order to preclude deposits (and possible plugging) on the nozzle: Each nozzle operates with a differential pressure of between 200 and 300 psi, and spray water flow is separately controlled in order to maintain droplet size between 100 and 200 microns. Flow to each nozzle must be controlled between 50 to 100 percent of design flow to maintain proper droplet size. To achieve the desired set point exit temperature at any operating humidifier throughput, the proper number of nozzles must be utilized within their permitted flow range. For this reason, an automatic control system has been installed to sequentially activate the appropriate number of spray nozzles and control their flows, and maintain the desired operating temperature.

During the humidifier testing, various methods of collecting the tar in the tar trap were tried. The tar trap was designed as a large pressurized vessel in which various internal configurations could be tested. Unacceptable results were obtained using baffle- and vane-type internals. The highest tar removal occurred when an impact plate was used, and velocities were increased by manually throttling across the inlet valve to the tar trap. As a result of the pressure drop, greatly increased velocities were measured across the separator. This improvement indicated that higher-velocity removal devices should be tested in subsequent runs. A cyclone-type device was developed for testing in Run 95 (see Section 5.3.2).

The side-stream tray scrubber had been modified for this run by replacing the valve trays with simple sieve plates having 1/4-inch-diameter holes. Tar fouling had occurred in the valve trays during the previous test. This unit was operated and evaluated during Test Run 92. No fouling was experienced with this design modification.

The venturi scrubber was first tested during Test Run 94 and has been demonstrated to be a very effective secondary device for removing tar not collected in the tar separator. The venturi scrubber operates at a nearly isothermal condition with the incoming gas from the tar separators. The successful operation of the venturi scrubber paved the way for the testing of the balance of the downstream equipment. Tar removed by the venturi scrubber is readily 
TABLE 13. HUMIDIFIER PERFORMANCE COMPARISON OF PREDICTED VERSUS ACTUAL MOISTURE CONTENT OF GAS - TEST RUN 96

\begin{tabular}{|l|c|c|}
\hline Estimated Water Content & $\begin{array}{c}\text { Calculated } \\
\text { Values }\end{array}$ & $\begin{array}{c}\text { Sample } \\
\text { Probe }\end{array}$ \\
\hline $\mathrm{H}_{2} \mathrm{O}$ in gasifier outlet gas & 16.9 & 13 \\
$\mathrm{H}_{2} \mathrm{O}$ in humidifier outlet gas & 30.3 & 30 \\
$\mathrm{H}_{2} \mathrm{O}$ in Venturi outlet gas & 24.7 & 22 \\
\hline \multicolumn{2}{|c|}{ Process Stream Conditions } \\
\hline \multicolumn{2}{|c|}{} \\
Temperature at the gasifier & $990^{\circ} \mathrm{F}$ \\
Temperature at the cyclone & $850^{\circ} \mathrm{F}$ \\
Temperature at the humidifier Exit & $354^{\circ} \mathrm{F}$ \\
Temperature at the venturi & $255^{\circ} \mathrm{F}$ \\
Air Flow Rate (SCFH) to gasifier & 29,400 \\
Steam Flow Rate (lb/hr) to gasifier & 813 \\
System Pressure (psig) & 117 \\
Water Flow Rate into Humidifier (1b/hr) & 530 \\
& \\
\hline
\end{tabular}


separated from the scrub water in a pressurized decanter and the water is recirculated to the venturi. The tar, which remains liquid at room temperature, is drained from the decanter on a regular basis. Makeup water is supplied from the recirculating decanter circuit. Tar removed from the gas in this manner is higher in water content than the relatively dry tar removed in the tar separator. Analyses of the tars and liquors collected from this system collected during subsequent runs are presented in Tables 18 through 21. later in this Section of the report.

\subsubsection{Phase IV of Test Program - Complete Full-Flow Cleanup System Test Results}

The objective of Test Runs 95 and 96 was to determine the operational capability of the complete FFCUS. Figure 18 is a schematic diagram of the fixedbed gasifier and FFCUS. The dashed line indicates the component equipment tested during Test Run 94. The entire system was tested during Test Runs 95 through 98. Figure 19 shows the sample locations referred to in tables where data were collected during these runs. Modifications were made on the basis of test results. In addition, improvements to the gasifier ancillary hardware were tested. This strategy has succeeded, and each test run has been built upon the results and knowledge gained from the previous test. The successful completion of over 120 hours of continuous operation during Test Run 96, delivering excellent quality gas of $175+10 \mathrm{Btu}$, was a milestone achievement.

During Test Runs 95 through 98, the gasifier and FFCUS operated for longer periods (250 to over 700 hours, versus typical 50 to 150 hours) and at higher throughputs than previously achieved, e.g., 2,000 $\mathrm{lb} / \mathrm{hr}$ coal feed. This was due to design improvements made to the gasifier and its ancillary equipment. Steady operation during each test period was maintained for a minimum of 24 hours in order to allow samples to be collected for heat and material balance calculations. Results of these calculations have shown an acceptable closure (within a few percent). Table 14 gives the range of gas compositions measured during Test Runs 95 and 96.

Throughout this series of test runs the dust cyclone performed adequately as defined by removal of sufficient dust to avoid plugging problems in downstream equipment. Dust removal rates of approximately 80 percent of inlet levels were measured. Erosion of the cyclone walls, measured continuously by experimental sensors installed by Argonne National Labs, was acceptable, typically 0 to 2 thousandths of an inch (mil) for each period.

Table 15 presents a typical analysis of the size distribution of the dust collected by the cyclone.

Cooling of the raw, low-Btu gas causes high-boiling tars to condense. A portion of these tars was collected in the humidifier. To collect the balance, it was necessary to install a droplet separator to remove the tars from the gas stream. As a result of testing conducted during Test Run 94 , it was determined that a cyclone device with velocities in the range of 150 feet per minute (ft/min) performed acceptably as a tar separator. A test cyclone was manufactured on-site to replace the large vessel used in Run 94 . This 


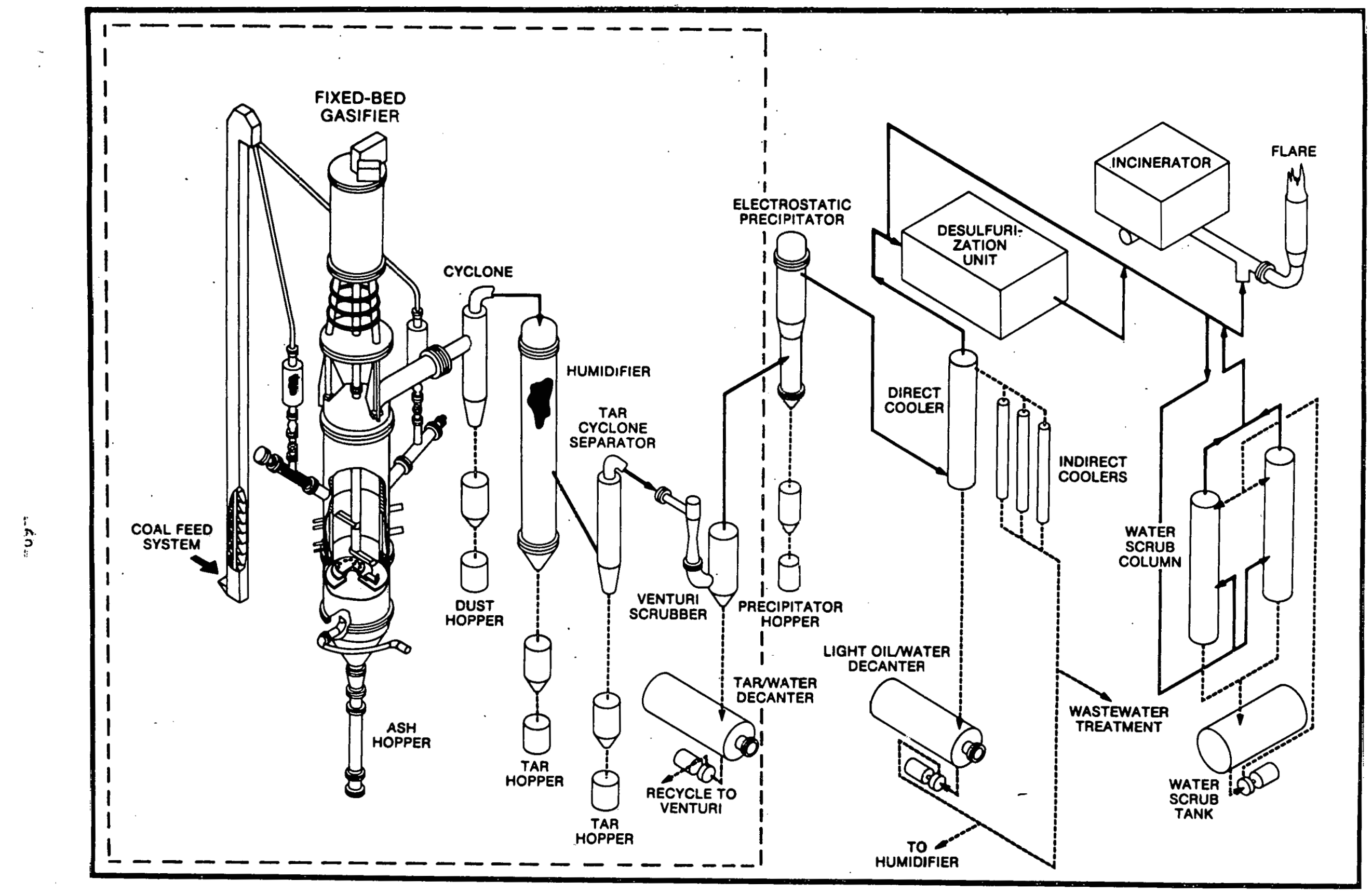

FIGURE 18. FIXED-BED GASIFIER AND FULL-FLOW CLEANUP SYSTEM RUNS 95 TO 98 CONFIGURATION TESTED IN RUN 94 - INSIDE DASHED LINES 


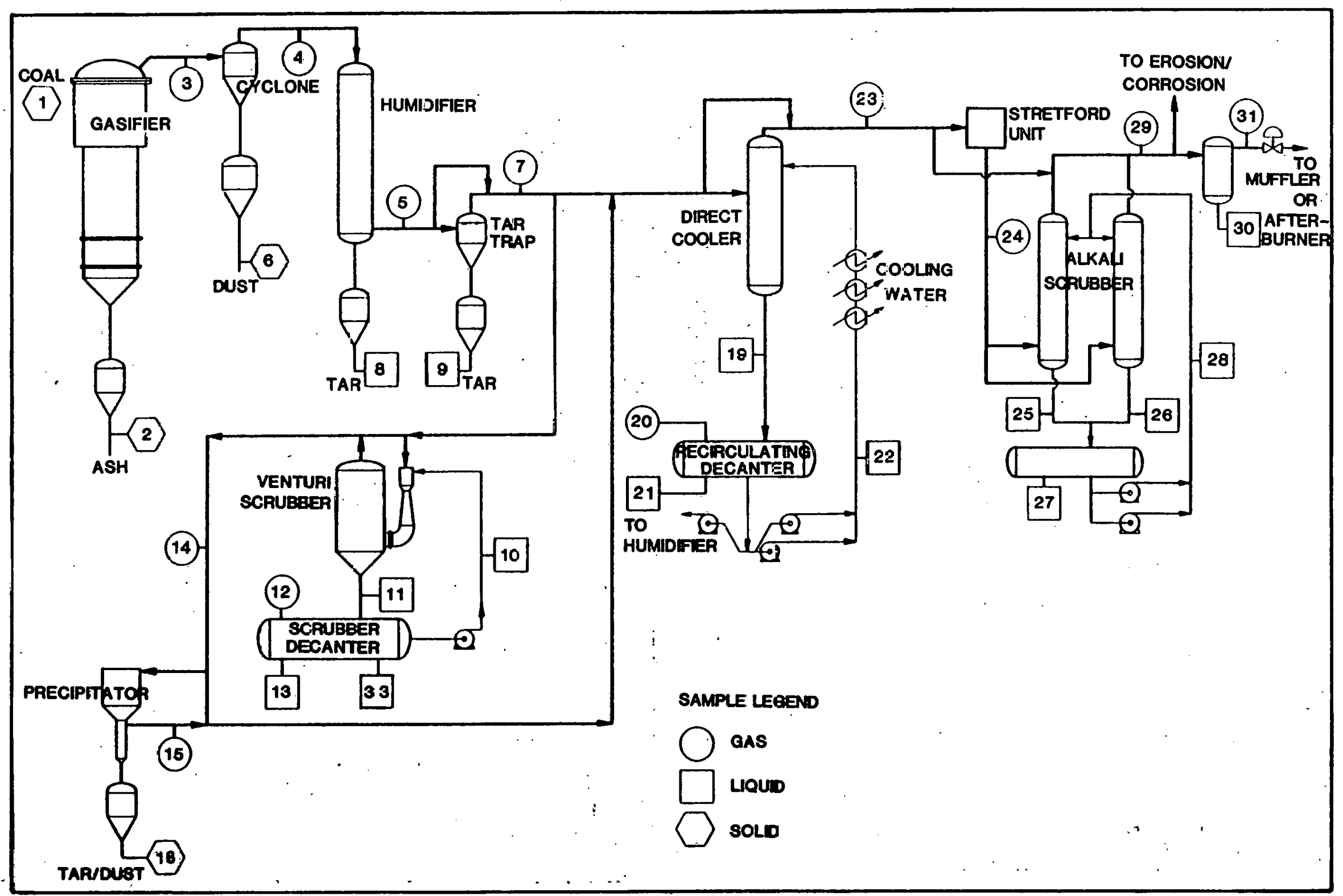

FIGURE 19. SAMPLE LOCATIONS FOR FULL-FLOW :aAS CLEANUP SYSTEM - TEST RUNS 94 TO 98 
TABLE 14. PRODUCER GAS COMPOSITION (VOLUME PERCENT, DRY BASIS) - TEST RUNS 95 AND 96

\begin{tabular}{|l|r|r|}
\hline & Raw Gas & \multicolumn{2}{|c|}{ Clean Gas } \\
\hline $\mathrm{H}_{2}$ & 14.5 to $\frac{16.5}{16.5}$ & 14.5 to 17.0 \\
$\mathrm{CO}_{2}$ & 7.0 to 10.0 & 6.2 to 10.8 \\
$\mathrm{C}_{2} \mathrm{H}_{6}$ & .26 to .35 & .27 to .35 \\
$\mathrm{H}_{2} \mathrm{~S}$ & .32 to .35 & \\
$\mathrm{O}_{2}$ & .56 to .73 & .68 to .74 \\
$\mathrm{H}_{2}$ & 47.0 to 50.0 & 47.0 to 50.1 \\
$\mathrm{CH}_{4}$ & 3.0 to 3.5 & 2.9 to 4.6 \\
$\mathrm{CO}$ & 18.0 to 23.3 & 17.7 to 23.0 \\
\hline
\end{tabular}

TABLE 15. SIZE DISTRIBUTION OF CYCLONE DUST TEST RUN 96

\begin{tabular}{|c|c|c|c|}
\hline \multirow{2}{*}{$\begin{array}{c}\text { Particle Size } \\
\text { (microns) }\end{array}$} & \multicolumn{3}{|c|}{ Cumulative Wt \& Oversize } \\
\cline { 2 - 4 } & $\begin{array}{c}\text { Composite } \\
\text { Sample }\end{array}$ & $\begin{array}{c}\text { Grab Sample } \\
\text { No. 1 }\end{array}$ & $\begin{array}{c}\text { Grab Sample } \\
\text { No. 2 }\end{array}$ \\
\hline 128.0 & 4.4 & 2.8 & 3.9 \\
80.6 & 30.0 & 26.6 & 25.4 \\
64.0 & 51.6 & 38.9 & 40.2 \\
50.8 & 71.7 & 59.7 & 66.1 \\
40.3 & 83.3 & 77.8 & 79.3 \\
32.0 & 89.9 & 83.8 & 84.8 \\
25.4 & 94.3 & 92.4 & 93.0 \\
16.0 & 98.5 & 97.2 & 98.2 \\
10.0 & 99.6 & 99.8 & 99.5 \\
6.4 & 100.0 & 100.0 & 100.0 \\
4.0 & & & \\
& & & \\
\hline
\end{tabular}


device functioned effectively. It removed a high percentage of the incoming tar, did not plug, and erosion was minimal. The only disadvantage to this design has been the pressure drop attendant with its operation. Typical compositions of the tar collected in the humidifier and tar separator are presented in Tables 16 and 17.

As a result of the success of the single cyclone design, a commercially manufactured "multiclone" was installed to be tested during Test Run 101 . This unit promises high droplet removal efficiencies at lower pressure drops than experienced with the in-house design.

The ESP was first checked prior to Test Run 95. Difficulties were encountered during pre-operational checking in maintaining proper voltage without excessive sparking. The vendor was unable to visit the site to assist METC until Test Run 96. Analysis of the system revealed several problems. The first problem was a difficulty in controlling primary voltage to the high voltage transformer, solved by installation of a powerstat on the electrical feed. The next problem was bending of the wire electrodes and their electromotively induced oscillation within the collector tubes, solved by replacing the wires with 1/2-inch threaded rods cross-connected at the bottom to reduce induced oscillation. After these problems were corrected, the ESP was readied for future testing. Further testing of the ESP was performed during Test Runs 97 and 98. A diagram of the ESP is shown in Figure 20.

Data concerning the operation of the ESP were preliminary and inconclusive. Tests to characterize its operation are scheduled for future runs.

The full-flow system direct and indirect coolers were first tested during Test Run 95. The cooling system lowered the gas stream temperature to the desired $100^{\circ} \mathrm{F}$ for hydrogen sulfide removal. Cooling the gas from approximately 300 to $100^{\circ} \mathrm{F}$ resulted in the condensation and washing of light oils from the gas stream. These oils form a distinct layer above the water in the recirculating decanter and were easily separated. A rotating sampler was developed by METC in order to determine the location of the oil layer in the decanter and for removal of accumulated oil. An analysis of the oils drained from the recirculating decanter is included in Tables 18 through 20.

The liquors from the direct cooler are collected in the pressurized recirculating decanter, separated, and a sour water fraction is constantly recycled. Portions of this water are used to supply water to the humidifier spray nozzles and makeup water to the venturi system. The separation capability of this decanter proved adequate and the resulting cleanliness level of the liquor, in terms of both particulates and oils, produced no pump problems, heat exchanger blockage, observable erosion, and required only modest filtration levels in order to maintain humidifier nozzle operability. Excess water resulting from condensation of the unreacted steam fed to the gasifier is bled to the waste pond for treatment. Table 21 provides an analysis of the recirculating decanter liquor.

Tests were run to determine the mass loading of aerosols in the gas stream and the particle size distribution of dust captured by the various process streams. These test data are shown in Table 22, and the average data are graphically represented in Figure 21 . 
TABLE 16. TEMPERATURE-VISCOSITY PROFILE FOR RECOVERED TAR TEST RUN 90

\begin{tabular}{|c|r|}
\hline Temperature $\left({ }^{0} \mathrm{~F}\right)$ & Viscosity $(\mathrm{cp})$ \\
\hline 203 & 3,010 \\
221 & 2,500 \\
234 & 2,005 \\
241 & 1,910 \\
259 & 1,555 \\
268 & 1,200 \\
279 & 990 \\
284 & 950 \\
\hline
\end{tabular}

TABLE 17. COMPOSITION OF RECOVERED TAR - TEST RUN 95

\begin{tabular}{|l|c|c|}
\hline Percent by Weight & Humidifier & Tar Separator \\
\hline Moisture & 0.26 & 0.53 \\
Ash & 0.59 & 0.60 \\
Hydrogen & 5.47 & 5.15 \\
Carbon & 86.99 & 85.98 \\
Sulfur & 1.43 & 1.39 \\
Nitrogen & -1.21 & 1.19 \\
Oxygen & 4.05 & 5.16 \\
\hline Heating Value (Btu/1b) & 15,369 & 15,528 \\
\hline
\end{tabular}




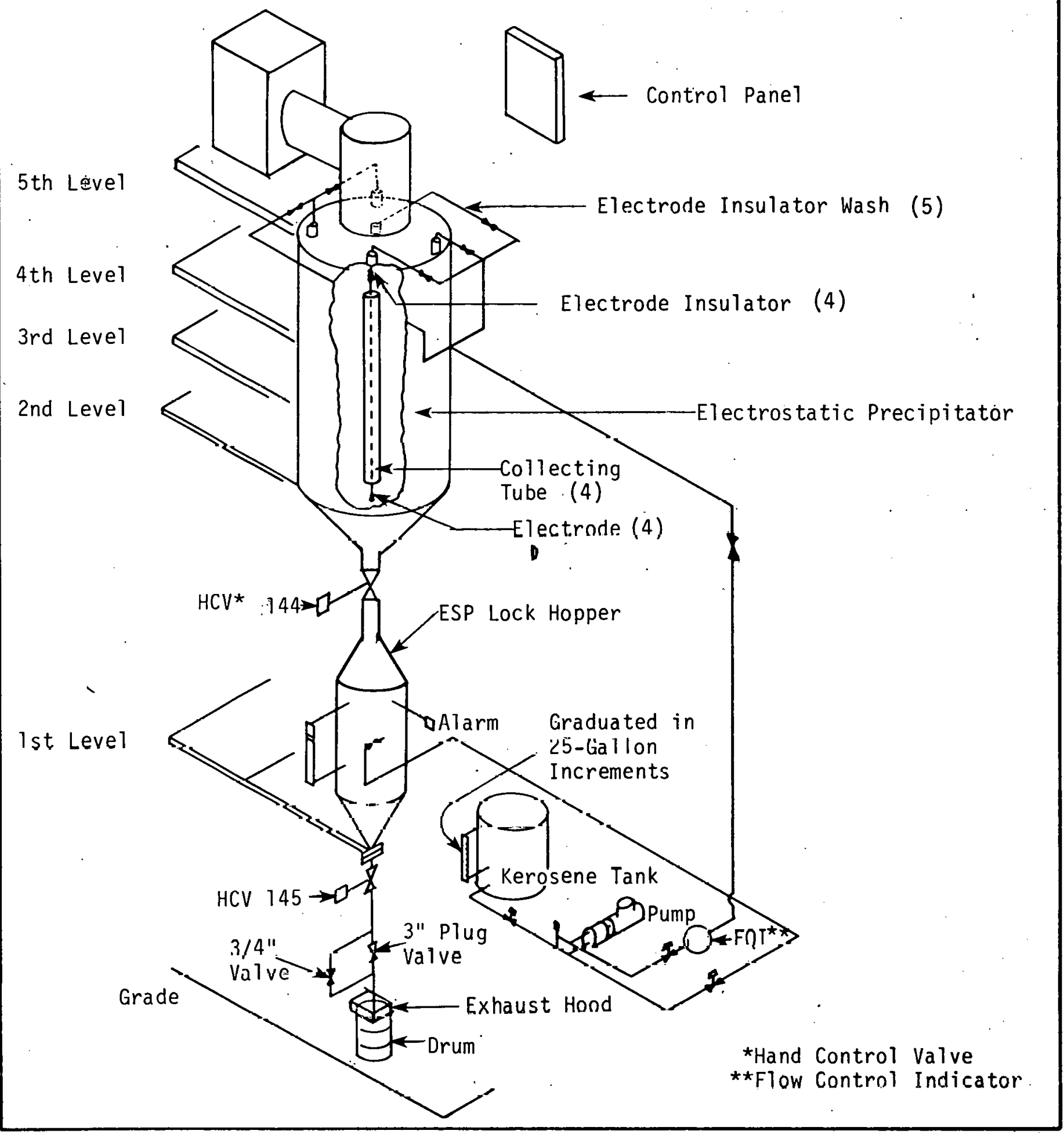

FIGURE 20. ELECTROSTATIC PRECIPITATOR 
TABLE 18. TAR AND OIL SAMPLES TAKEN DURING TEST RUN 95

\begin{tabular}{|c|c|c|c|c|}
\hline \multirow[b]{2}{*}{ Sampling Point } & \multicolumn{2}{|c|}{ Venturi Scrubber } & \multicolumn{2}{|c|}{ Direct Coolers } \\
\hline & $\$ 13$ & $\$ 33$ & $\mathrm{~S} 21$ & $\mathrm{~S} 22$ \\
\hline & Tar & Tar & $0 i 1$ & $0 i 1$ \\
\hline Wt. $\%$ & & & & \\
\hline Water & 3.37 & 2.08 & 1.02 & 0.2 \\
\hline Dust & 8.11 & 6.75 & 0.075 & 0.76 \\
\hline Ash & 0.24 & 0.36 & 0 & 0 \\
\hline Sulfur & 0.62 & 0.60 & 0.26 & 0.22 \\
\hline Hydrogen & 5.82 & 6.26 & 6.97 & 7.46 \\
\hline Carbon & 85.99 & 83.29 & 88.25 & 87.33 \\
\hline $\begin{array}{l}\text { Heat Content } \\
(\text { Btu/lb) }\end{array}$ & 15,795 & 14,939 & 18,906 & 16,909 \\
\hline Specific Gravity & 1.007 & 1.012 & 1.004 & 1.004 \\
\hline Viscosity* & $>100,000$ & $28.8 \times 10^{3}$ & 5.5 & 5.5 \\
\hline
\end{tabular}

Note: Samples are as-received

* by Brookfield Viscometer, Model LV. Viscosity in cp at $25^{\circ} \mathrm{C}$ 
TAR AND OIL SAMPLES TAKEN DURING TEST RUN 96

\begin{tabular}{|l|c|c|}
\hline \multirow{2}{*}{ Sampling Point } & $\begin{array}{c}\text { Recirculating } \\
\text { Decanter }\end{array}$ & $\begin{array}{c}\text { Venturi } \\
\text { Scrubber }\end{array}$ \\
\cline { 2 - 3 } & S34 & S13 \\
\hline Percent Wt/Wt: & $0 i 1$ & Tar \\
\hline Water & & 1.10 \\
Dust & 0.10 & 2.19 \\
Ash & 0.41 & 0.15 \\
Sulfur & 0 & 6.17 \\
Hydrogen & 0.98 & 82.83 \\
Carbon & 7.44 & 16,846 \\
\hline Hedi Cunlenl (Btu/1b) & 87.83 & 1.010 \\
\hline Specific Gravity & 18,962 & 435 \\
\hline Viscosity (Brookfield at $24.4^{\circ} \mathrm{C}$ ) & 1.005 & 5.5 \\
\hline
\end{tabular}

Note: Samples are as-received

TABLE 20.

BOILING POINT RANGE OF TAR AND OIL SAMPLES FROM TEST RUN 96

\begin{tabular}{|c|c|c|}
\hline \multirow{2}{*}{ Sampling Point } & $\begin{array}{c}\text { Recirculating } \\
\text { Decanter }\end{array}$ & $\begin{array}{c}\text { Venturi } \\
\text { Scrubber }\end{array}$ \\
\cline { 2 - 3 } & S34 & S13 \\
\hline Simulated Boiling Point $\left({ }^{\circ} \mathrm{F}\right)$ & 0 il (wt \%) & Tar (wt \%) \\
\hline $232-352$ & 13.59 & 1.18 \\
$353-424$ & 28.92 & 3.86 \\
$426-472$ & 14.08 & 2.89 \\
$473-510$ & 7.10 & 2.63 \\
$511-552$ & 11.74 & 3.85 \\
$553-568$ & 3.29 & 2.29 \\
$569-651$ & 9.04 & 10.43 \\
$652-937$ & 5.46 & 19.73 \\
\hline
\end{tabular}


TABLE 21. LIQUOR SAMPLES TAKEN DURING TEST RUN 95

\begin{tabular}{|c|c|c|c|}
\hline Sample Location & S10 & S22 & S27 \\
\hline $\mathrm{pH}$ & 8.57 & 8.33 & 7.80 \\
\hline Bicarbonate & 1,787 & 22,800 & 2,574 \\
\hline Carbonate & 3,693 & 1,331 & 0 \\
\hline Chloride & 1,200 & 1,150 & 900 \\
\hline Cyanide & 0.36 & 3.4 & 2.6 \\
\hline Phenol & 2,700 & 6,750 . & 2,700 \\
\hline Sulfur, total. & 5,520 & 996 & 910 \\
\hline Sulfate & 13,500 & 1,840 & 2,110 \\
\hline Nitrogen, total & 1,790 & 1,360 & 540 \\
\hline Thiocynate & 1,820 & 290 & 255 \\
\hline Solids, total & 31,760 & 32,420 & 18,560 \\
\hline Suspended Solids & 860 & 11,420 & 10,360 \\
\hline Dissolved Solids & 30,900 & 21,000 & 8,200 \\
\hline \multicolumn{4}{|l|}{ Specific Cond. } \\
\hline$($ mhos $/ \mathrm{cm})$ & 56,000 & 35,000 & 14,000 \\
\hline Specific Gravity & 1.004 & 1.005 & 1.002 \\
\hline $\mathrm{Na}$ & 2.5 & 0.07 & 1.6 \\
\hline K & 2.5 & 0.07 & 1.6 \\
\hline Co & 0.01 & 0.01 & 0.01 \\
\hline Mo & 0.5 & 0.5 & 0.5 \\
\hline $\mathrm{Hg}$ & 0.00043 & 0.00008 & 0.00019 \\
\hline$v$ & 0.04 & 0.04 & 0.04 \\
\hline $\mathrm{Cr}$ & 0.01 & 0.01 & 0.01 \\
\hline $\mathrm{Ni}$ & 0.015 & 0.83 & 0.015 \\
\hline $\mathrm{Pb}$ & 0.03 & 0.03 & 0.03 \\
\hline
\end{tabular}

All values are in $\mathrm{mg} / 1$ except $\mathrm{pH}$, Specific Conductance, and Specific Gravity. Bicarbonate and carbonate in $\mathrm{mg} / \mathrm{l}\left(\mathrm{CaCO}_{3}\right.$ equivalent). 

TABLE 22. PARTICLE SIZE DISTRIBUTION OF DUST SAMPLES THROUGHOUT
CLEANUP SYSTEM - TEST RUN 95

\begin{tabular}{|c|c|c|c|c|c|c|c|c|c|c|c|c|}
\hline \multirow{3}{*}{$\begin{array}{l}\text { Size in Microns } \\
\text { Sample Location }\end{array}$} & \multicolumn{12}{|c|}{ Cumulative Weight Percent Oversize } \\
\hline & 128.0 & 80.6 & 64.0 & 50.8 & 40.3 & 32.0 & 25.4 & 16.0 & 10.1 & 6.4 & 4.0 & 2.5 \\
\hline & & & & & & & & & & & & \\
\hline Dust : 56 & 2.3 & 15.0 & 24.7 & 41.0 & 54.2 & 62.9 & 70.9 & 83.8 & 99.2 & 100.0 & & \\
\hline$\frac{\text { Aerosol Mass Loading }}{S-19}$ & & & & & & & & & & . & & \\
\hline $\begin{array}{l}0930-1030,9 / 25 / 80 \\
1117-1217,9 / 25 / 80 \\
1335-1435,9 / 25 / 80\end{array}$ & $\begin{array}{l}24.8 \\
29.4\end{array}$ & $\begin{array}{r}2.2 \\
33.6 \\
44.5\end{array}$ & $\begin{array}{r}9.8 \\
40.5 \\
57.9\end{array}$ & $\begin{array}{l}16.3 \\
47.5 \\
63.9\end{array}$ & $\begin{array}{l}26.1 \\
53.4 \\
68.3\end{array}$ & $\begin{array}{l}36.3 \\
57.3 \\
71.4\end{array}$ & $\begin{array}{l}46.3 \\
61.1 \\
74.1\end{array}$ & $\begin{array}{l}61.3 \\
70.1 \\
79.4\end{array}$ & $\begin{array}{l}74.1 \\
89.5 \\
99.1\end{array}$ & $\begin{array}{l}83.7 \\
100.0 \\
100.0\end{array}$ & 94.4 & 100.0 \\
\hline 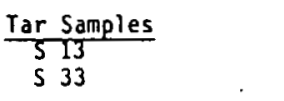 & $\begin{array}{l}2.3 \\
0\end{array}$ & $\begin{array}{l}5.9 \\
0\end{array}$ & $\begin{array}{l}9.2 \\
2.3\end{array}$ & $\begin{array}{r}14.6 \\
7.9\end{array}$ & $\begin{array}{l}24.5 \\
16.9\end{array}$ & $\begin{array}{l}39.0 \\
28.9\end{array}$ & $\begin{array}{l}65.9 \\
49.5\end{array}$ & $\begin{array}{l}79.7 \\
61.6\end{array}$ & $\begin{array}{r}68.3 \\
74.2\end{array}$ & $\begin{array}{l}94.7 \\
91.0\end{array}$ & $\begin{array}{l}100.0 \\
100.0\end{array}$ & \\
\hline ni) Samples & & . & & & & & . & & & & & \\
\hline 521 & 3.7 & 12.5 & 17.3 & 23.1 & 32.4 & 42.0. & 58.0 & 69.2 & $79.9^{\circ}$ & 91.7 & 100.0 & $\therefore$ \\
\hline Liquor Samples & & & & & & & & & & & & \\
\hline $\begin{array}{ll}S & 10 \\
S & 11 \\
S & 25 \\
5 & 27 \\
S & 28\end{array}$ & $\begin{array}{l}5.3 \\
6.3 \\
0 \\
4.2 \\
0.1\end{array}$ & $\begin{array}{r}12.4 \\
13.7 \\
0 \\
12.0 \\
5.5\end{array}$ & $\begin{array}{r}17.7 \\
21.9 \\
0.2 \\
18.9 \\
14.3\end{array}$ & $\begin{array}{r}22.0 \\
32.3 \\
3.0 \\
26.1 \\
21.6\end{array}$ & $\begin{array}{l}27.8 \\
42.8 \\
10.3 \\
33.4 \\
27.3\end{array}$ & $\begin{array}{l}33.9 \\
52.9 \\
20.5 \\
39.0 \\
32.8\end{array}$ & $\begin{array}{l}49.1 \\
70.1 \\
49.6 \\
53.3 \\
46.3\end{array}$ & $\begin{array}{l}62 . y \\
82.3 \\
75.5 \\
67.2 \\
59.0\end{array}$ & $\begin{array}{l}76.3 \\
90.8 \\
91.6 \\
82.3 \\
73.2\end{array}$ & $\begin{array}{l}90.0 \\
96.5 \\
98.1 \\
94.7 \\
87.5\end{array}$ & $\begin{array}{l}100.0 \\
100.0 \\
100.0 \\
100.0 \\
100.0\end{array}$ & \\
\hline
\end{tabular}

Ref.: ITRI, December 1979, 1980, 1981, 1982. 


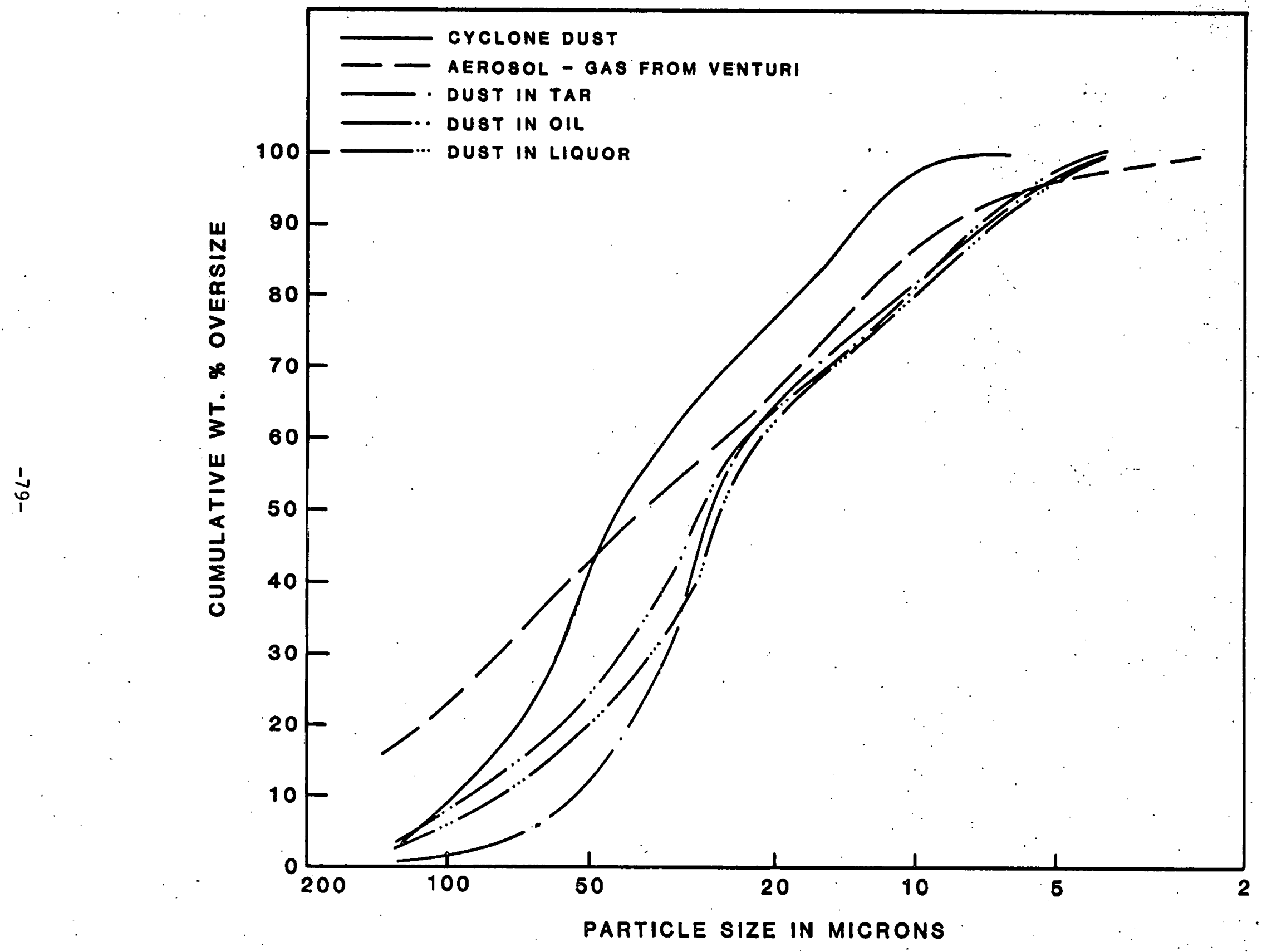

FIGURE 21. SIZE DISTRIBUTION OF PARTICULATES IN PROCESS GAS STREAM - TEST RUN 95 
The Stretford hydrogen sulfide removal system was initiated during Test Run 95. The Stretford system demonstrated its ability to remove the $\mathrm{H}_{2} \mathrm{~S}$ from the product gas to design levels for short periods of time. Product gas was cleaned by the system during approximately 100 hours of Stretford operation. Table 23 presents a summary of the sulfur removal capability exhibited by the Stretford system during this initial phase of its operation.

A fugitive flow of gas inadvertently bypassed the direct cooler and contaminated the Stretford solution with hydrocarbons during the early phases of the checkout. This contamination was suspected of causing severe foaming and entrainment of Stretford liquor in the absorber outlet gas streams during Runs 96 and 97. Various efforts to reduce the entrainment, including use of a defoaming agent, were unsuccessful. As a result of this problem, it was difficult to obtain accurate gas samples at the original sampling locations. Another problem was the inability to properly separate out the sulfur captured in the stretford liquor. It appeared that the fine sulfur particles became coated with the contaminating hydrocarbons and were unable to grow into a filterable size. Measures were taken to address these difficulties; these are described with the test results of Runs 99 and 100 later in this Section.

The purpose of the water scrub columns is to remove trace quantities of any water-soluble contaminants which might be present in the gas stream at this point. Of particular concern was the potential presence of alkali and heavy metals resulting from carryover of alkali-based stretford liquor. The alkali scrubber equipment has worked well. Alkali metal concentrations in the cleaned product gas have been very low. Table 24 provides a summary of the pertinent gas contaminant levels and testifies to the cleanup system performance.

The primary goal of Test Runs 97 and 98 (May through August, 1981) was to provide clean, low-Btu gas fuel for the Corrosion/Erosion Test Program (see Section 4.7 of this report). The requirement to provide 300 hours and 600 hours of testing for the second and third phases of that program were the principal objectives of these two respective gasifier tests.

The fixed-bed gasiffer and FFC.IIS nperated extremely well during Runs 97 and 98 , logging a total of 1,116 test hours and maintaining an 88 percent availability. Test Runs 97 and 98 each ended due to erosion failure of the lower stirrer arm at its end caps. Subsequent improvements to the design and manufacture of the arms have eliminated this problem.

Operation of the cleanup system during Test Run 97 was troubled by continual foaming present in the Stretford system. A defoaming agent used to mitigate the problem was generally unsuccessful. For this reason it was determined that a low-sulfur coal (i.e., less than 1.2 percent) that did not require the Stretford system for emission control would be used during Test Run 98. This allowed most of the gasifier-related testing activities to continue with the Stretford inoperative while redesign activities were accomplished. A Lower Kittanning coal was consequently tested during Test Run 98 . Table 25 shows the chemical analyses for the coals used during Test runs 97 and 98 , while Table 26 presents the respective ash analyses. Gasifier and cleanup system operation with Lower Kittanning coal feedstock was virtually flawless and 
TABLE 23. PRELIMINARY PERFORMANCE SUMMARY OF THE STRETFORD SULFUR REMOVAL SYSTEM - TEST RUNS 95 AND 96

\begin{tabular}{|l|c|c|}
\hline Constituent & $\begin{array}{l}\text { Inlet to } \\
\text { Stretford Unit } \\
\text { (ppm) }\end{array}$ & $\begin{array}{l}\text { Outlet from } \\
\text { Stretford Unit } \\
\text { (ppm) }\end{array}$ \\
\hline $\mathrm{H}_{2} \mathrm{~S}$ & $3,650-4,500$ & $0.2-50$ \\
$\mathrm{COS}$ & $250-410$ & $235-360$ \\
$\mathrm{CS}_{2}$ & $12-60$ & $11-57$ \\
$\mathrm{CH}_{3} \mathrm{SH}$ & $1.5-4.0$ & $<1.5$ \\
$\mathrm{Thiophene}_{\mathrm{HCN}}$ & $4-18$ & $3-12$ \\
$\mathrm{H}$ & 78 & $<1.0$ \\
\hline
\end{tabular}

TABLE 24. REPRESENTATIVE GAS CLEANUP SYSTEM PERFORMANCE - TEST RUNS 95 AND 96

\begin{tabular}{|c|c|c|c|c|}
\hline $\begin{array}{l}\text { Cleanup } \\
\text { System } \\
\text { Location }\end{array}$ & $\begin{array}{l}\text { Particulate } \\
\text { Loading } \\
\left(\mathrm{gm} / \mathrm{m}^{3}\right)^{\star}\end{array}$ & $\begin{array}{l}\text { Tar } \\
\text { Loading } \\
\left(\mathrm{gm} / \mathrm{m}^{3}\right)\end{array}$ & $\begin{array}{l}\text { Hydrogen } \\
\text { Sulfide } \\
\text { (ppm) }\end{array}$ & $\begin{array}{l}\text { Alkali } \\
\text { Metal s } \\
(\text { ppb })^{\star \star}\end{array}$ \\
\hline After cyclone & - & $11.0-15.0$ & - & - \\
\hline After humidifier & $0.20-0.60$ & $8.0-10.0$ & - & - \\
\hline $\begin{array}{l}\text { After tar } \\
\text { separator }\end{array}$ & $0.05-0.50$ & $1.0-4.0$ & - & - \\
\hline $\begin{array}{l}\text { After venturi } \\
\text { scrubber }\end{array}$ & $0.03-0.05$ & $0.1-1.0$ & - & - \\
\hline Before Stretford & - & - & $3,600-4,500$ & - \\
\hline After Stretford & - & - & $0.2-50$ & - \\
\hline $\begin{array}{l}\text { Before alkali } \\
\text { scrubber }\end{array}$ & - & - & - & $50-100$ \\
\hline $\begin{array}{l}\text { After alkali } \\
\text { scrubber }\end{array}$ & - & - & - & $1-15$ \\
\hline
\end{tabular}

Note: The data shown above are typical and do not represent a single test run.

Note: The Stretford system has not completed its shakedown testing and performance results were preliminary.

* Grams per cubic meter

**Parts per billion 
TABLE 25. ELEMENTAL ANALYSIS, HEAT CONTENT, ASH FUSION TEMPERATURE, AND FREE SWELLING INDEX

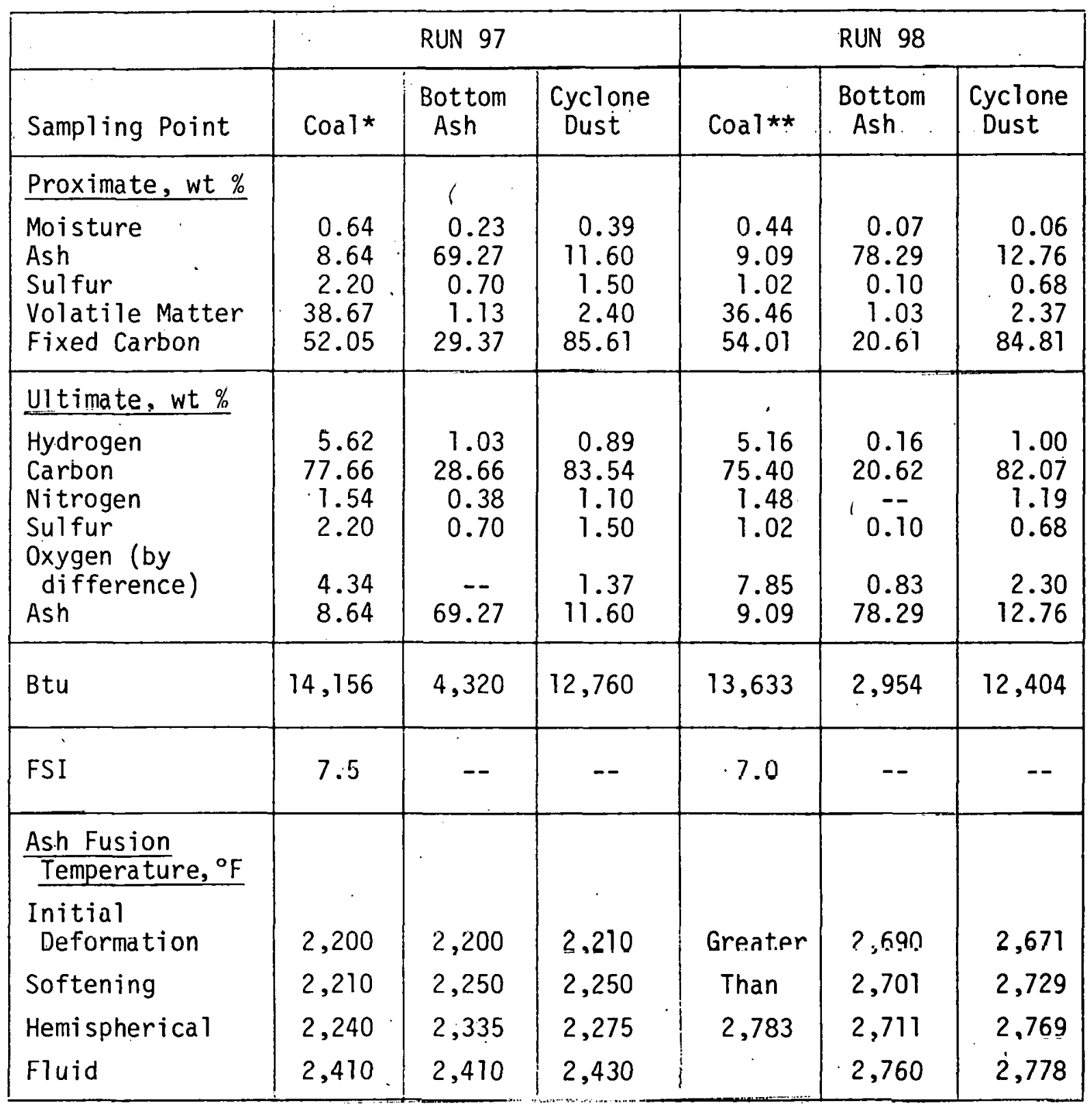

* Pittsburgh No. 8 Coal

** Lower Kittanning Coal

Note: Samples taken from respective material balance period from each test run. 
TABLE 26. ANALYSIS OF ASH (HTA)* IN WEIGHT PERCENT

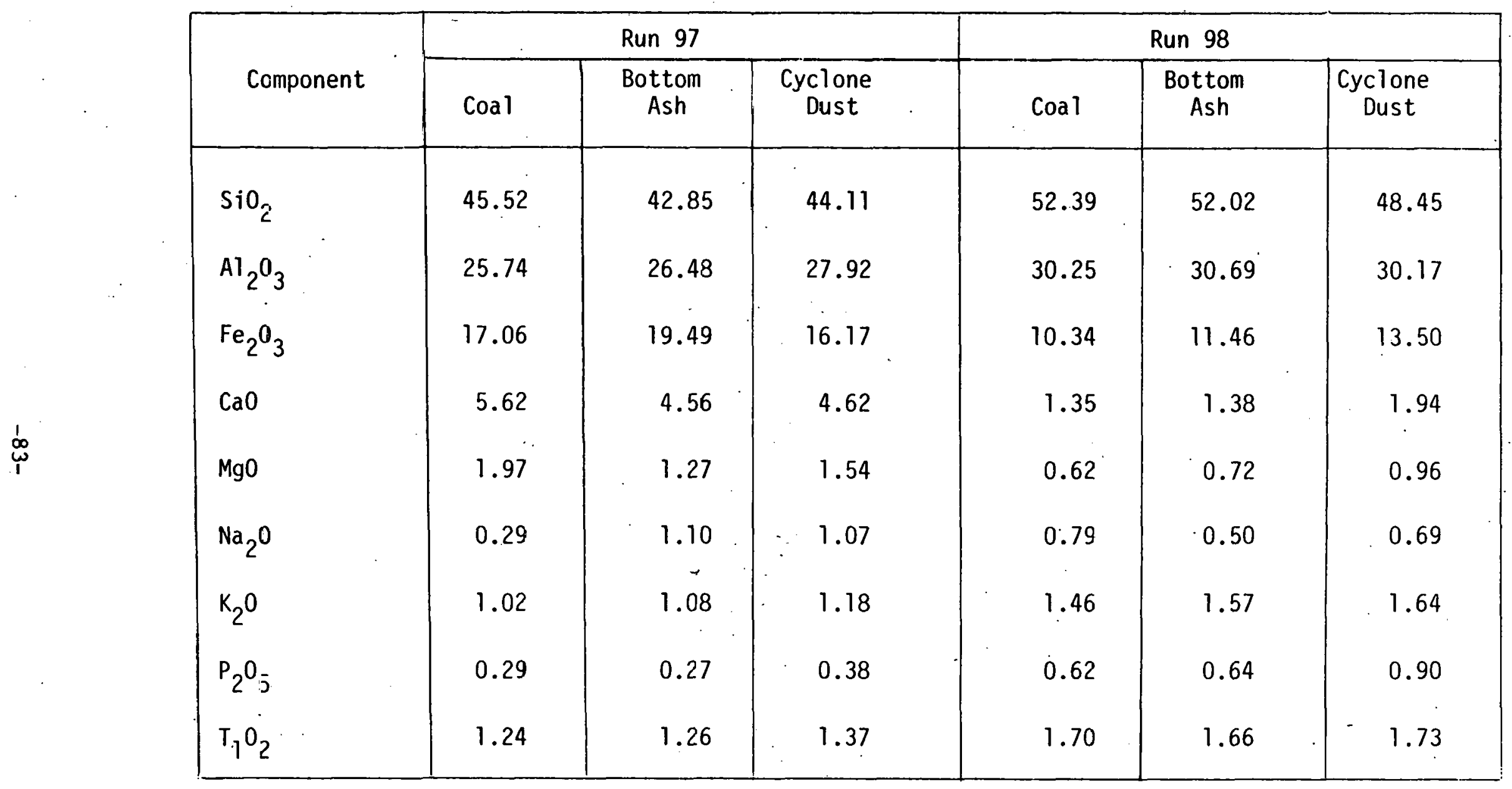

Samples taken from respective material balance period from each test run.

* High Temperature Ash 
required little adjustment of control parameters from previous tests on Arkwright coals. The average gas analyses for these runs are given in Table 27. During each test run, a 24-hour material balance period was maintained in order to characterize flow streams. Tables 28 through 32 summarize the analytical data measured during the material balance periods for Test Runs 97 and 98. Using these analytical data, material and energy balance calculations were performed for steady-state periods occurring during the runs. These balances are summarized in Figures 22 and 23 which also include process data averaged from several stable periods of consistent operation from each test run. Data from Test Run 97 were from periods totaling 71 hours, and data from Test Run 98 were averaged from periods totaling 93 hours.

Temperature, pressure, gas composition, and flow rate data were taken from the representative periods and averaged by the ADACS data acquisition system. Where possible, obviously erroneous data were screened from the calculations to facilitate accuracy. Mass flow rate data were calculated from the operator log sheets for coal feed, tar, oil and dust removal values. These values were carefully screened to exclude times when abnormal operation might have occurred. Chemical analyses of the process streams were performed during the "24 Hour, Heat and Material Balance Period". These values were assumed to be representative for the entire calculation period.

On-line analysis of the product gas does not account for all of the constituents in the gas. Estimates of the minor components were performed from laboratory results of analyses conducted during Run 99 and engineering estimates (see Tables 34 and 35 ). Calculation of the heating value of the gas analysis, Table 33, yielded values within 2 percent of the measured heating value determined by the on-line gas calorimeter.

The material and energy balance was calculated and compiled in the table included in Figures 22 and 23. Gas leakage from the cleanup system to the vent system was estimated. This was done by estimating theoretical gas production through a nitrogen balance, and calculating the losses as a portion of the product gas. The primary sources of gas leakage were lockhopper operation, packing leaks, Stretford flash gas, and deterioration with time of lockhopper vent valves. This flow represents approximately 6 percent of the low-Btu gas produced.

The overall material balance for Run 97 showed agreement to within five percent when total gas leakage from the system of about 4,000 SCFH was factored into the calculations (based on the nitrogen balance); disproportionate amounts of carbon and oxygen were still unexplained. Difficulties encountered during Run 97 with the control of the ESP and the humidifier may have caused this discrepancy. Sulfur balance calculations were based on estimates because of the inability to remove sulfur product from the stretford system.

The Test Run 98 material balance showed agreement to within less than one-half percent. The total energy balance closes to within two percent. The ability to operate within these tolerances was aided by improved performance of the humidifier, and bypassing of the ESP and Stretford system by the cleanup train. 
TABLE 27. MAJOR GAS ANALYSES BY ON-LINE GAS CHROMATOGRAPH IN VOLUME PERCENT

\begin{tabular}{|l|c|c|c|c|}
\hline & \multicolumn{2}{|c|}{ Run 97 } & \multicolumn{2}{c|}{ Run 98 } \\
\hline & $\begin{array}{c}\text { Producer } \\
\text { Gas }\end{array}$ & $\begin{array}{c}\text { Clean Product } \\
\text { Gas }\end{array}$ & $\begin{array}{c}\text { Producer } \\
\text { Gas }\end{array}$ & $\begin{array}{c}\text { Clean Product } \\
\text { Gas }\end{array}$ \\
\hline $\mathrm{H}_{2}$ & $15.29 \pm .84$ & $16.00 \pm .53$ & $16.43 \pm .99$ & $17.10 \pm .58$ \\
$\mathrm{CO}_{2}$ & $7.84 \pm .78$ & $6.88 \pm .28$ & $8.51 \pm .62$ & $8.55 \pm .75$ \\
$\mathrm{C}_{2} \mathrm{H}_{6}$ & $0.29 \pm .02$ & $0.26 \pm .03$ & $0.26 \pm .06$ & $.25 \pm .07$ \\
$\mathrm{H}_{2} \mathrm{~S}$ & $0.35 \pm .15$ & $0.05 \pm .03$ & $0.17 \pm .04$ & $.18 \pm .02$ \\
$\mathrm{O}_{2}$ & $0.58 \pm .03$ & $0.73 \pm .06$ & $0.64 \pm .04$ & $0.70 \pm .04$ \\
$\mathrm{~N}_{2}$ & $48.52 \pm 1.45$ & $48.57 \pm .66$ & $47.66 \pm 2.05$ & $47.56 \pm 1.69$ \\
$\mathrm{CH}_{4}$ & $2.82 \pm .20$ & $.2 .97 \pm .23$ & $2.28 \pm .57$ & $2.37 \pm .48$ \\
$\mathrm{C0}$ & $21.28 \pm .86$ & $21.50 \pm .61$ & $21.67 \pm 1.24$ & $22.13 \pm 1.00$ \\
\hline
\end{tabular}

This data averaged from reported daily averages of each respective entire test run. 
TABLE 28. CYCLONE DUST, SAMPLING POINT S6 SIZE DISTRIBUTION CUMULATIVE WEIGHT PERCENT OVERSIZE

\begin{tabular}{|c|c|c|c|}
\hline \multicolumn{2}{|c|}{ Run 97} & \multicolumn{2}{|c|}{ Run 98} \\
\hline $\begin{array}{l}\text { Size in } \\
\text { Microns }(\mu \mathrm{m})\end{array}$ & & $\begin{array}{l}\text { Size in } \\
\text { Microns ( } \mu \mathrm{m})\end{array}$ & \\
\hline 128 & 0.2 & 128 & 14.8 \\
\hline 80.6 & 1.3 & 80.6 & 28.3 \\
\hline 64.0 & 8.6 & 64.0 & 57.8 \\
\hline 50.8 & 21.9 & 50.8 & 68.5 \\
\hline 10.3 & 37.4 & 40.3 & 75.5 \\
\hline 32.0 & 55.4 & 32.0 & 80.3 \\
\hline 25.4 & 71.5 & 25.4 & 83.4 \\
\hline 16.0 & 89.4 & 16.0 & 89.6 \\
\hline 10.1 & 97.1 & 10.1 & 99.7 \\
\hline $6.4 \%$ & 99.3 & 8.0 & 100.0 \\
\hline 4.0 & .100 .0 & Mediạn $(\mu \mathrm{m})$ & 72.3 \\
\hline 2.5 & -- & & \\
\hline 1.0 & $=-$ & . & \\
\hline 1.0 & -- & & . \\
\hline Median ( $\mu \mathrm{m})$ & 34.31 & & \\
\hline
\end{tabular}

Note: Samples taken during respective test run material balance periods 
TABLE 29. COMPOSITION OF RECOVERED TAR

\begin{tabular}{|c|c|c|c|c|c|c|c|}
\hline \multirow{2}{*}{\multicolumn{2}{|c|}{ Sampling Point }} & \multicolumn{3}{|c|}{ Run 97} & \multicolumn{3}{|c|}{ Run 98} \\
\hline & & \multirow{2}{*}{$\begin{array}{c}\text { Humidifier } \\
0.52\end{array}$} & \multirow{2}{*}{$\begin{array}{c}\text { Tar } \\
\text { Sep } \\
0.48\end{array}$} & \multirow{2}{*}{$\begin{array}{c}\begin{array}{c}\text { Venturi } \\
\text { Decanter }\end{array} \\
0.88\end{array}$} & \multirow{2}{*}{$\begin{array}{c}\text { Humidifier } \\
0.53\end{array}$} & \multirow{2}{*}{$\begin{array}{l}\text { Tar } \\
\text { Sep } \\
\\
0.60\end{array}$} & \multirow{2}{*}{$\begin{array}{c}\begin{array}{l}\text { Venturi } \\
\text { Decanter }\end{array} \\
1.15\end{array}$} \\
\hline Moisture & wt\% & & & & & & \\
\hline Ash & $w t \%$ & 0.38 & 0.26 & 0.15 & 2.10 & 0.33 & 0.22 \\
\hline Hydrogen & $w t \%$ & 5.32 & 5.26 & 5.61 & 5.55 & 5.77 & 6.93 \\
\hline Carbon & $w t \%$ & 86.69 & 87.41 & 73.78 & 75.45 & 79.69 & 84.37 \\
\hline Sulfur & $w t \%$ & 1.23 & 1.25 & 1.23 & 0.57 & 0.56 & 0.64 \\
\hline Nitrogen & wt $\%$ & 1.41 & 1.57. & 1.43 & 1.63 & 1.87 & 1.22 \\
\hline 0xygen* & $w t \%$ & 4.45 & 3.77 & 16.92 & 14.17 & 11.18 & 5.47 \\
\hline Btu & & 15420 & 15710 & 15464 & 13,410 & 14,979 & 17,406 \\
\hline Specific & avity & -- & -- & 1.015 & $\cdots$ & --- & 1.015 \\
\hline
\end{tabular}

* Oxygen by difference

NOTE: (1) All results are in Wt\% except 3 tu and specific gravity

(2) Solid tar at $\mathrm{S} 8$ and 59

(3) Samples were taken during respective test run material.balance periods 
TABLE 30. LIQUOR SAMPLES

\begin{tabular}{|l|r|r|r|r|}
\hline & \multicolumn{2}{|c|}{ Run 97} & \multicolumn{2}{c|}{ Run 98 } \\
\cline { 2 - 5 } & $\begin{array}{c}\text { Venturi } \\
\text { Liquor }\end{array}$ & $\begin{array}{c}\text { Recirculating } \\
\text { Liquor }\end{array}$ & $\begin{array}{r}\text { Venturi } \\
\text { Liquor }\end{array}$ & $\begin{array}{c}\text { Recirculating } \\
\text { Liquor }\end{array}$ \\
\hline $\mathrm{pH}$ & 8.58 & 8.60 & 8.29 & 8.50 \\
Ammonia (Free) & 9,290 & 9,800 & 14,400 & 9,800 \\
Alkalinity as CaCO 3 & 7,580 & 40,130 & 223,000 & 257,000 \\
Chloride & 1,300 & 1320 & 21,000 & 1,200 \\
Cyanide & 88 & 72 & 4 & 115 \\
COD & 94,350 & 68,500 & 216,000 & 102,000 \\
Phenol & 1,880 & 1,610 & 142 & 380 \\
TKN (Kjeldahi Nitrogen) & 10,260 & 12,100 & 18,800 & 19,600 \\
Sulfur, Total & 2,217 & 1,330 & 1,100 & 680 \\
Sulfide & 722 & 890 & 780 & 110 \\
Thiocyanate & 3,230 & 980 & 600 & 1,000 \\
Sodium & 8.5 & 10.5 & 16 & 4.3 \\
Potassium & .33 & 3.8 & 2.1 & 0.9 \\
Vanadium & $\leq .015$ & $\leq 0.015$ & 0.5 & $\leq 0.2$ \\
Specific Gravity & 1.013 & 1.000 & 1.025 & 1.025 \\
$\star \star$ Total Solids & 44,335 & 33,480 & 26,500 & 2,000 \\
$\star$ Tar and 0il & 33,120 & 3,970 & 5,200 & 5,760 \\
\hline
\end{tabular}

* Freon Extraction

$\star \star$ Residue on Evaporation (ROE) at $180^{\circ} \mathrm{C}$

Note: (1) All values in $\mathrm{mg} / 1$ except $\mathrm{pH}$ and specific gravity

(2) All sample composites taken during material balance periods of respective test runs 
TABLE 31. RECIRCULATING DECANTER OIL SAMPLES

\begin{tabular}{|l|c|c|}
\hline Analysis & Run 97 & Run 98 \\
\hline Water & 0.22 & $-0-$ \\
Dust & 0.001 & 0.91 \\
Ash & $-0-$ & 0.10 \\
Sulfur & 0.85 & 0.55 \\
Hydrogen & 11.59 & 8.65 \\
Carbon & 86.44 & 85.57 \\
Nitrogen & 0.13 & 0.83 \\
Heat Content (Btu) & 20,438 & 19,000 \\
Specific Gravity & 1.015 & 1.006 \\
Viscosity* & 2.0 & 9.0 \\
\hline
\end{tabular}

* By Brookfield Viscometer, Model L.V. Viscosity in $\mathrm{cp}$ at $23.3^{\circ} \mathrm{C}$

Note: (1) Samples taken during respective test run material balance periods

(2) All results are on "as received" basis

(3) All results are in $W t \%$ except 8 tu, specific gravity, and viscosity

TABLE 32. BOILING POINT RANGE OF OIL SAMPLES FROM RECIRCULATING DECANTER

\begin{tabular}{|l|r|r|r|}
\hline \multicolumn{2}{|c|}{ Run 97 } & \multicolumn{2}{c|}{ Run 98 } \\
\hline Boiling Range ${ }^{\circ} \mathrm{F}$ & Wt $\%$ & Boil ing Range ${ }^{\circ} \mathrm{F}$ & Wt $\%$ \\
\hline & & & \\
$331-352$ & 22.48 & $231-352$ & 16.88 \\
$353-424$ & 30.54 & $352-424$ & 18.82 \\
$425-472$ & 15.15 & $425-472$ & 16.08 \\
$473-498$ & 10.74 & $473-510$ & 13.68 \\
$499-541$ & 3.65 & $511-550$ & 7.06 \\
$542-637$ & 6.98 & $551-568$ & 7.63 \\
Above 637 & 1.45 & $569-651$ & 8.03 \\
& & $652-937$ & 10.07 \\
\hline
\end{tabular}

Note: Samples were taken during respective test run material balance periods 


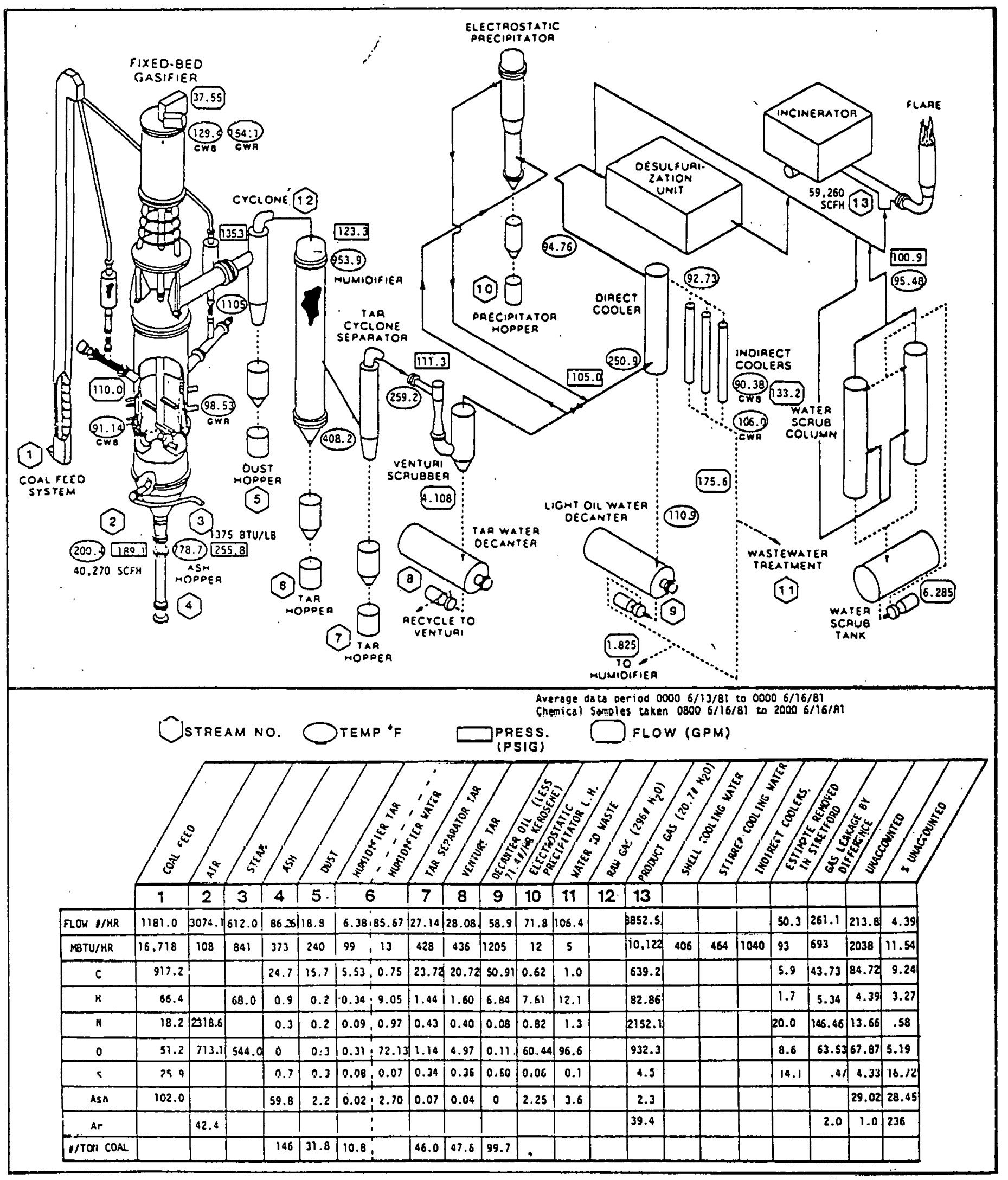

FIGURE 22. TEST RUN 97 FLOW DIAGRAM AND MATERIAL AND ENERGY BALANCE 


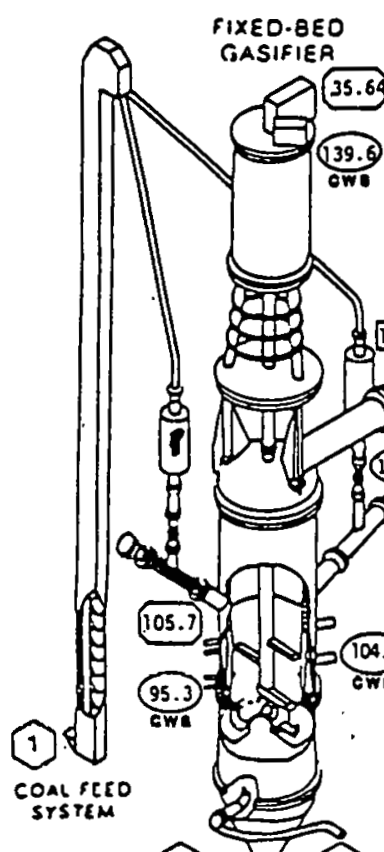

(2) (202.) [189.2] 850.801 .4 50.600 SCFH

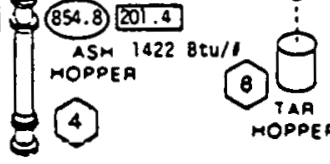

(

CrCLONE 12

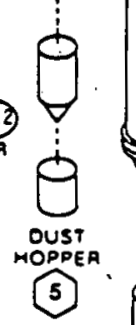

\section{ELECTAOSTATIC
PAECIPITATOQ}

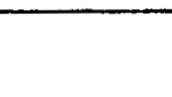

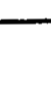

-

19.7

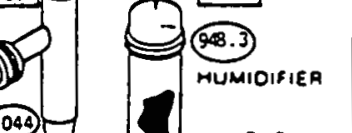

1044)

MUMIOIFIEA

005.5

(392.1.

Y

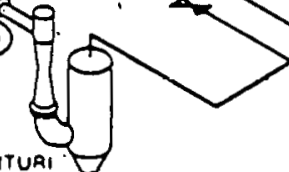

(106.)

INCINERATOA FLAR

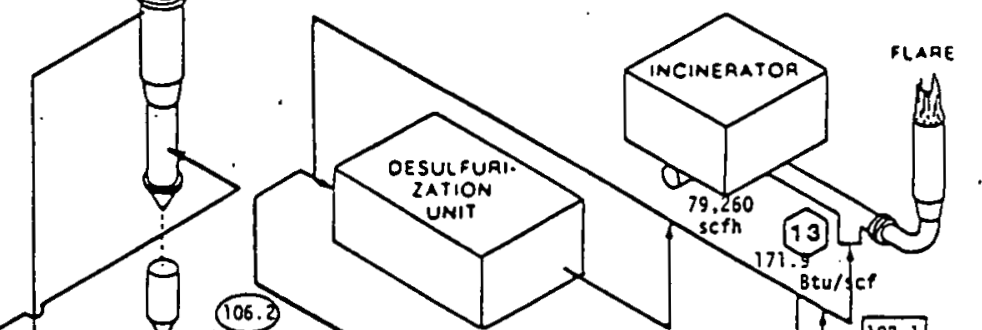

(7) 9 TAA $\begin{gathered}\text { RECTLIETO } \\ \text { VENTURI }\end{gathered}$

4.779

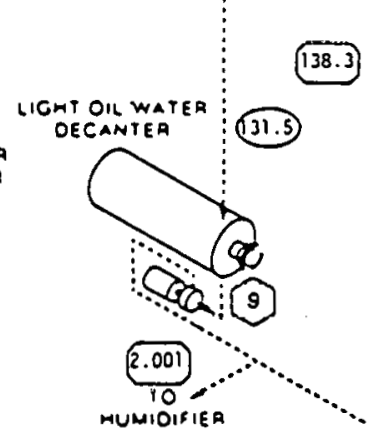

$\because 120.1$ WATER

CWr COlIMAN

$\sqrt{102.1}$

Ostreamno. Otemp of

PRESS. $\square$ FLOW (GPM)

(PSIG)

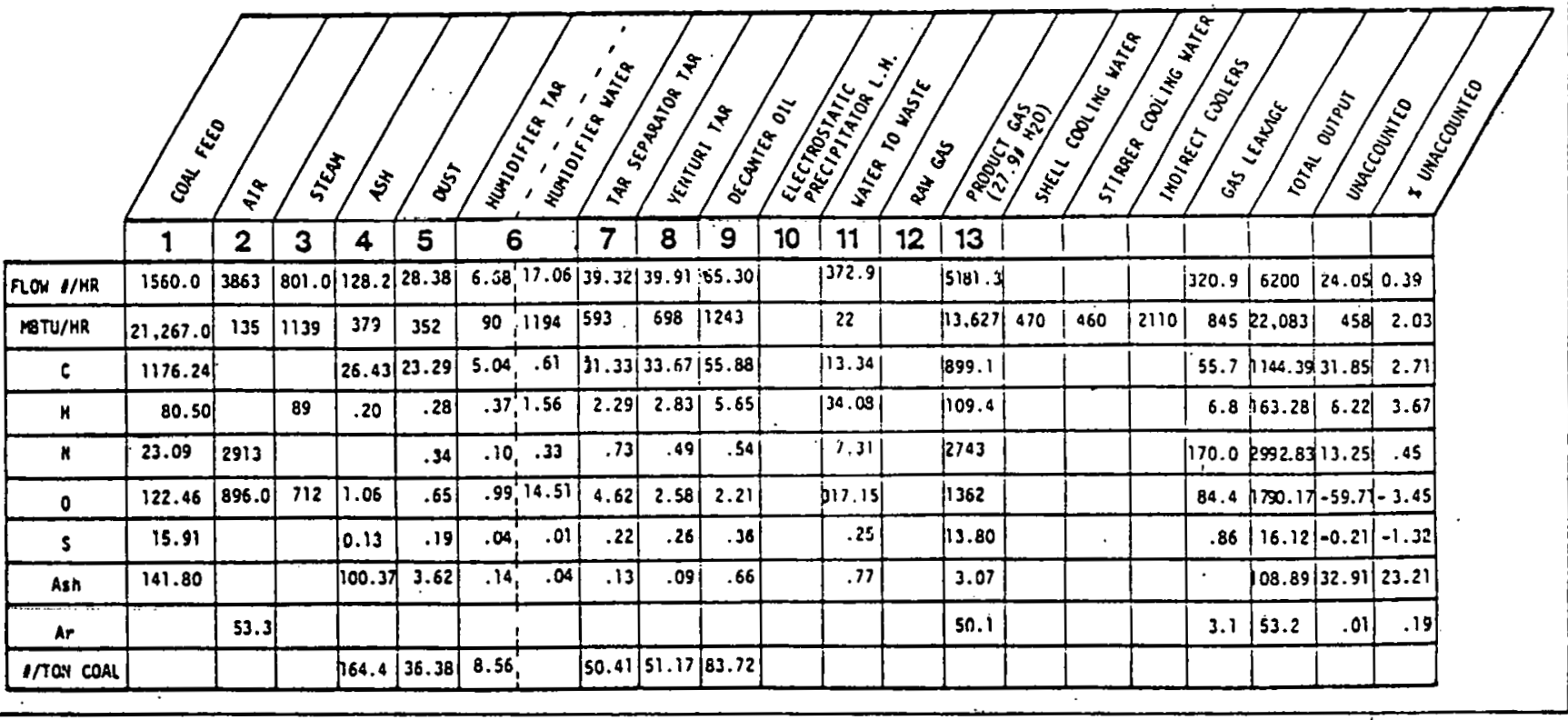

FIGURE 23. TEST RUN 98 FLOW DIAGRAM AND MATERIAL AND ENERGY BALANCE 
Several operational problems had to be overcome during Test Runs 99 and 100:

Run 99:

- The facility steam boiler unexpectedly failed.

- The facility high-pressure air compressor developed a crack in the cooling jacket.

- The coal bucket elevator motor burned out and was out of service for repair three times in 36 hours for four to six hours each time.

- Wet and frozen coal resulted in erratic coal feed.

Run 100:

- High concentrations of toxic gas emissions resulting from excessive stirrer shaft wear and associated seal deterioration posed a possible environmental and personnel hazard which precluded continued operation of the gasifier.

In spite of the numerous difficulties listed above, analytical tests performed during Run 99 yielded some useful information, presented in Tables 34 and 35 . These data are representative of the Arkwright (Pittsburgh No.8) coal tested extensively in earlier runs. They give insight into the quantities of illuminant hydrocarbons carried by the gas phase through the tail end of the cleanup system. The presence of these compounds in the gas are responsible for approximately ten percent of the total heating value of the product gas and raise the heating value from a calculated value of 155 Btu (major gas species) to approximately $170 \mathrm{Btu}$ as measured by the on-line calorimeter. Recalculation of gas heating value using an estimate of illuminant concentrations has been consistent with the measured heating value.

The objectives of Test Run No. 99 were to identify the source of the problems plaguing the operation of the Stretford Sulfur Removal System. A representative from the manutacturer was sent to assess the system and assist in this effort. Prior to Run 99, the ESP was repositioned immediately downstream of the direct cooler in the cleanup train. In addition, a droplet separator was installed immediately upstream of the Stretford system. This was done to reduce the potential for trace levels of hydrocarbon carryover into the Stretford system. These changes in the process configuration can be seen by comparing the sampling diagrams in Figure 19 with those in Figure 24 . Analytical test results showed that the total hydrocarbon content entering the Stretford system was within the vendor's design specifications (see Table 34). However, testing indicated that the Stretford system was unable to operate properly at the design liquor flowrate $(44 \mathrm{gpm})$ to the absorber tower. Operation above approximately $10 \mathrm{gpm}$ resulted in flooding of the column. Inspection of the hardware revealed that the absorber trays delivered by the vendor did not conform to the detailed design drawing. The column had been equipped with one-half the specified number of holes.

The Stretford system was, therefore, modified to be consistent with the vendor's design drawings. An alternative tray design was fabricated and 
TABLE 33. LEVELIZED GAS ANALYSIS USED FOR MATERIAL BALANCE CALCULATION

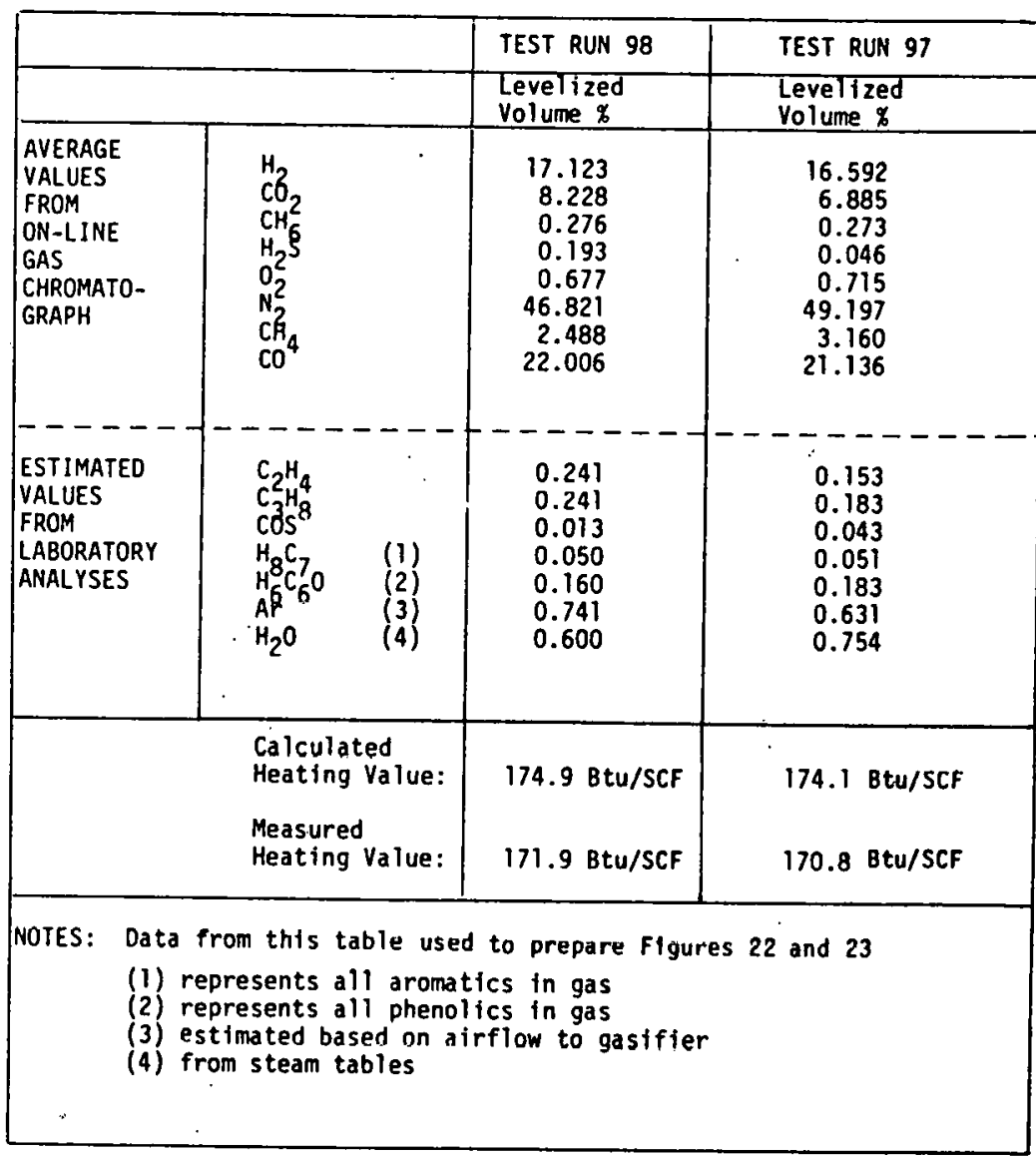

NOTE: TABLE 34 FOLLOWS THIS PAGE

TABLE 35. MASS LOADING OF TARS AND WATER AT CYCLONE OUTLET (S-4) - TEST RUN 99

\begin{tabular}{|c|c|l|c|c|}
\hline Date & $\begin{array}{c}\text { Sampling } \\
\text { Point }\end{array}$ & $\begin{array}{c}\text { Gasifier } \\
\text { Conditions }\end{array}$ & $\begin{array}{c}\text { Tar Loadings } \\
\left(\mathrm{gm} / \mathrm{m}^{3}\right)\end{array}$ & $\begin{array}{c}\text { Water Loadings } \\
\left(\mathrm{gm} / \mathrm{m}^{3}\right)\end{array}$ \\
\hline $3-19-82$ & S-4 & Stable & 16.4 & 77.0 \\
$3-20-82$ & S-4 & Stable & 10.5 & 80.5 \\
$3-21-82$ & S-4 & Stable & 18.5 & 82.5 \\
$3-29-82$ & S-4 & Unstable & 19.2 & 79.2 \\
\hline
\end{tabular}


TABLE 34. GAS QUALITY MEASURED ENTERING SULFUR REMOVAL SYSTEM - TEST RUN 99

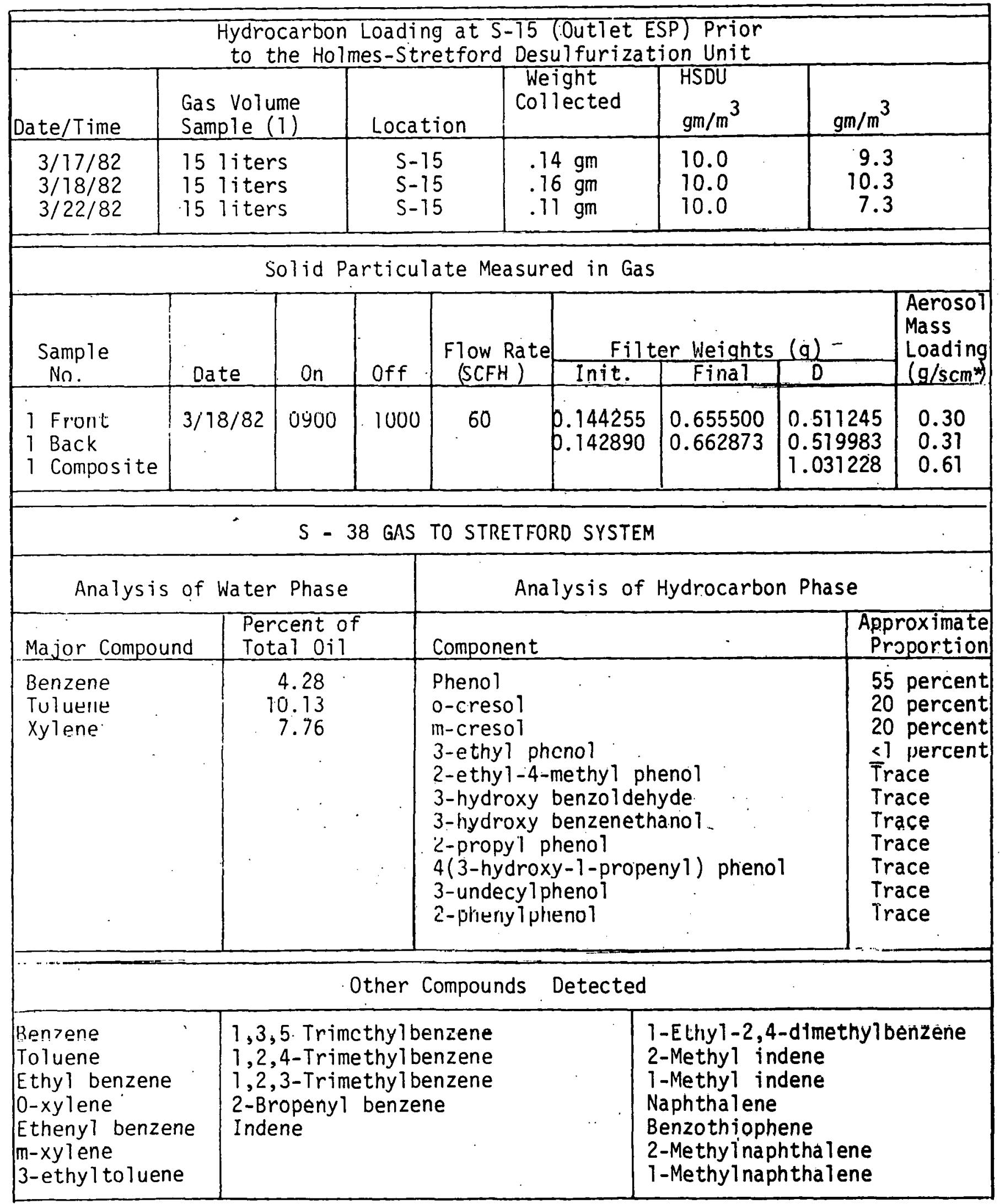

*Grams per Standard Cubic Meter 


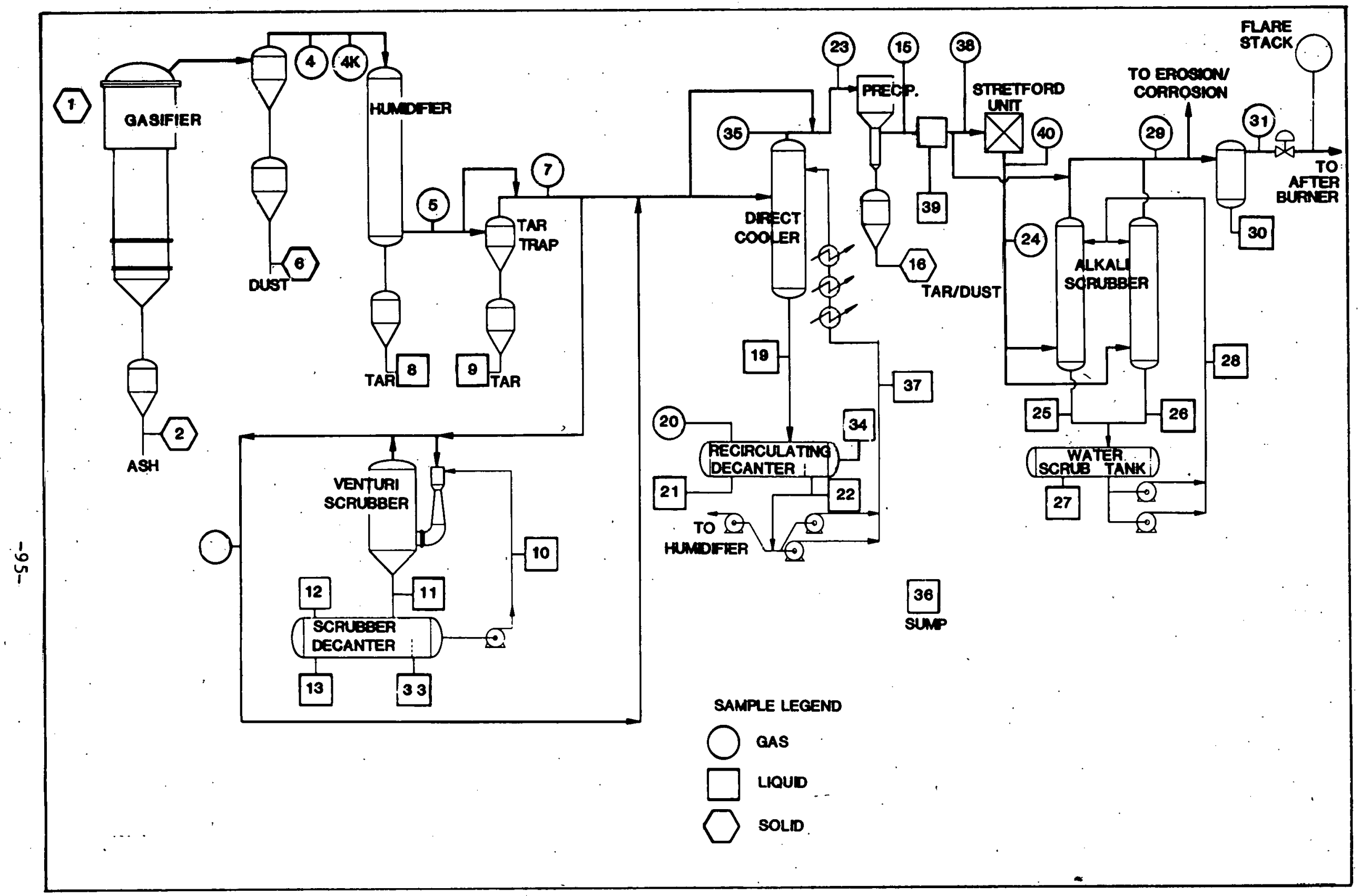

FIGURE 24. SAMPLE LOCATIONS FOR FULL-FLOW GAS CLEANUP SYSTEM - TEST RUNS 99 AND 100 
knock-out pots were installed to capture any inadvertent carryover from the absorber or flash tank. These modifications were all made in an attempt to alleviate absorber flooding and to achieve the design absorber flow rate as well as make the system more forgiving in the event of carryover. They were tested during Test Run 100. A comparison of the $\mathrm{H}_{2} \mathrm{~S}$ inlet and outlet gas concentrations for Test Runs 99 and 100 is presented in Figure 25. Although large improvements in performance are indicated, sufficient data to verify continued operation at these conditions were not obtained.

Test Run 100 had two primary goals: to verify the Stretford operation and to test the gasifier's fines-utilization ability by feeding coal briquettes. These activities were being tested simultaneously when the test run was prematurely terminated due to excessive leakage through the seals at the stirrer shaft penetration of the gasifier dome. Prior to the completion of the test run, data indicated a significant improvement in the performance of the Stretford system. The next test run should complete the performance determination of the stretford system and should open the way for implementation of system testing.

\subsection{RESULTS FROM COMPLEMENTARY PROJECTS}

Detailed descriptions of these complementary programs and their results can be obtained by contacting the METC program office.

\subsubsection{Environmental Health And Safety Research}

Since Test Run 95, accomplishments of EH\&S activities include implementation of compliance monitoring of all effluent streams: air, wastewater, and solid wastes. Other accomplishments include characterization of wastewaters; characterization of gasifier byproducts and development of a reuse and disposal program; completion of a workplace HHAS; and implementation of a clinical occupational medical surveillance program.

Byproduct Characterization and Environmental Management. Gaseous emissions, wastewaters, and șolid byproducts generated by the METC gasifier have been characterized. Table 36 summarizes the analyses conducted at each sample point. These data are taken for process design purposes as well as for environmental characterization. Table 37 lists the data collected during Runs 85 through 100. Detailed data are available from the METC program office.

Ambient air monitoring activities have been conducted to measure the impact of effluent streams on the environment. Ambient air monitors measuring criteria pollutants have been sited upwind and downwind of METC. Continuous monitoring has shown: METC emissions are undetectable for criteria pollutants; and national air quality standards are not exceeded.

Solid byproducts from the system include bottom ash, devolatilized coal dust, light oils, liquid tars, solid tars, and sulfur. Each byproduct stream has been characterized for RCRA toxicity; data indicate that byproducts are not hazardous as defined by RCRA (Figure 26 ).

An HHAS was conducted to provide a profile of the METC gasifier workplace environment for comparison with occupational safety and health standards. Chronic and acute occupational health effects related to the METC gasifier 


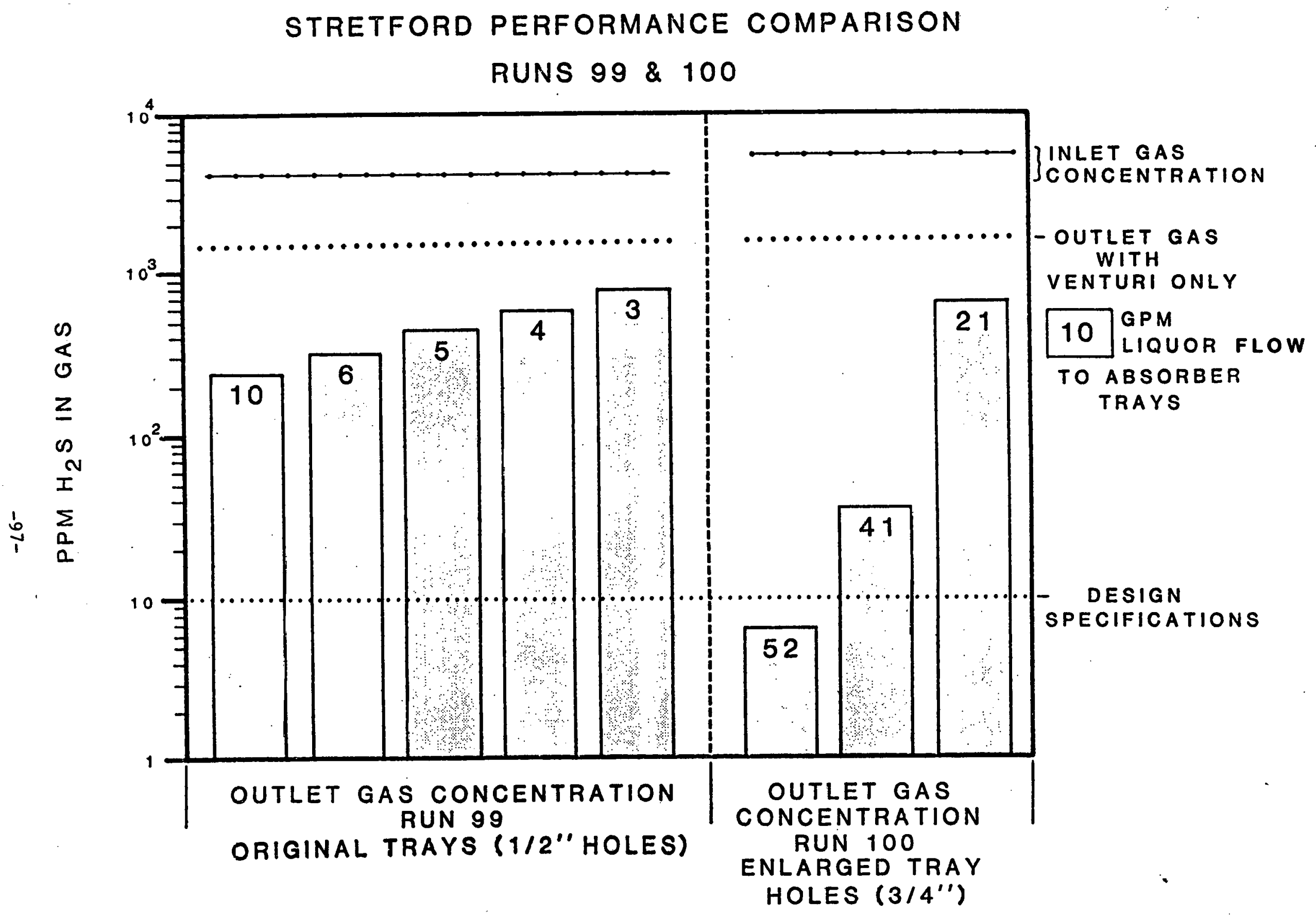

FJGURE 25. STRETFORD PERFORMANCE COMPARISON - RUNS 99 AND 100 
TF.B_E 36. SUMMARY OF GASIFIER SAMPLING POINT'S

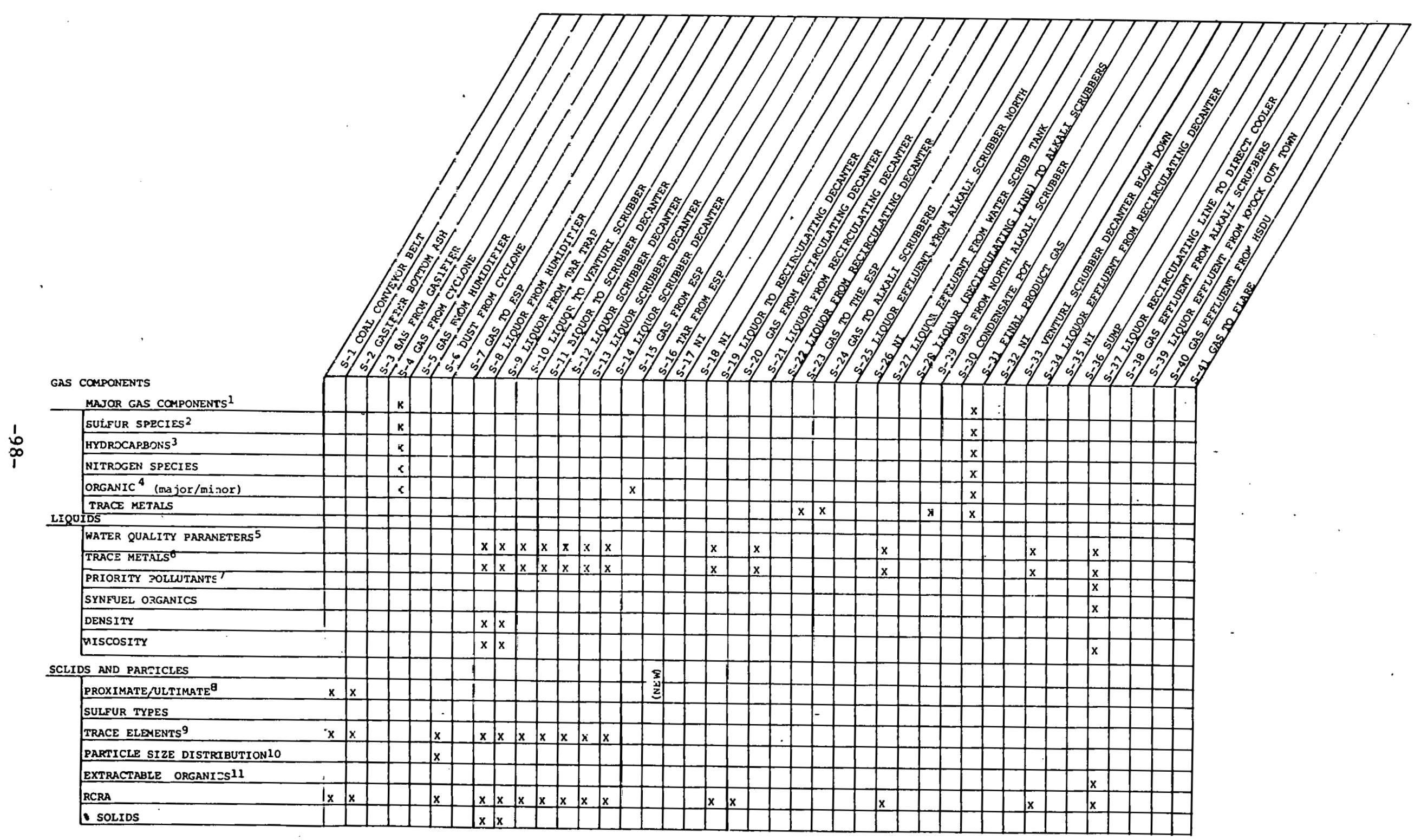

NI: No: in Use 
GAS COMPONENTS

$1_{\text {MAJOR GAS COMPONENTS }}$

$$
\mathrm{H}_{2}, \mathrm{O}_{2} \quad \mathrm{~N}_{2} \quad \mathrm{CH}_{4} \quad \mathrm{CO} \quad \mathrm{CO}_{2} \quad \mathrm{C}_{2}-\mathrm{C}_{4}
$$

${ }^{2}$ SULFUR SPECIES

$$
\mathrm{H}_{2} \mathrm{~S} \text {. } \mathrm{COS} \quad \mathrm{CH}_{3} \mathrm{SH} \quad \mathrm{CS}_{2} \text { Thiosulfate }
$$

${ }^{3}$ HYDROCARBONS

$$
\mathrm{C}_{2}, \mathrm{C}_{4}
$$

${ }^{4}$ ORGANICS

PNA's Aerosol/Vapor phase Ag filter/Tenax

\section{LIQUIDS}

\section{WATER QUALITY PARAMETERS}

$\mathrm{pH}$, specific conductance, hardness, acidity, alkalinity

bicarbonate, carbonate, COD, BOD, TOC, phenol, TIC, TS TDS,

TSS, TVS, sulfate, suifite, sulfide, nitrate, niluti, ammonia, TFN

${ }^{6}$ TRAC.F METALS

$\mathrm{Al}, \mathrm{Sb}, \mathrm{As}, \mathrm{Be}, \mathrm{B}, \mathrm{Ca}, \mathrm{Co}, \mathrm{Cu}, \mathrm{Fe}, \mathrm{Pb}, \mathrm{Mg}, \mathrm{Hg}, \mathrm{Mo}, \mathrm{Mn}, \mathrm{Ni}, \mathrm{K}$, $\mathrm{Na}, \mathrm{T}, \mathrm{Ti}, \mathrm{V}$ and $\mathrm{Z}$

$7_{\text {PRIORITY POLLUTANTS }}$

129 organic compounds listed in 40 CFR

SOLIDS AND PARTICLES

${ }^{8}$ PROXIMATE/ULTIMATE

$\begin{array}{lll}\text { Moisture } & \text { Hydrogen } & \text { Ash Fusion Temperature }{ }^{\circ} \mathrm{F} \\ \text { Ash } & \text { Carbon } & \text { Free Swelling Index } \\ \text { Sulfur } & \text { Nitrogen } & \\ \text { Vol. Matter } & \text { Sulfur } & \\ \text { Fix. Carbon } & \text { Oxygen (by difference) } \\ & \text { Ash }\end{array}$

\section{${ }^{9}$ TRACE ELEMENTS}

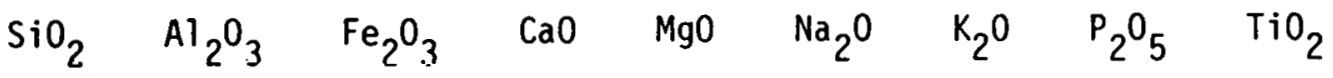

10 PARTICAL SIZE DISTRIBUTION

Study preformed on Coulter Counter

11 EXTRACT TABLE ORGANICS

PNA's 


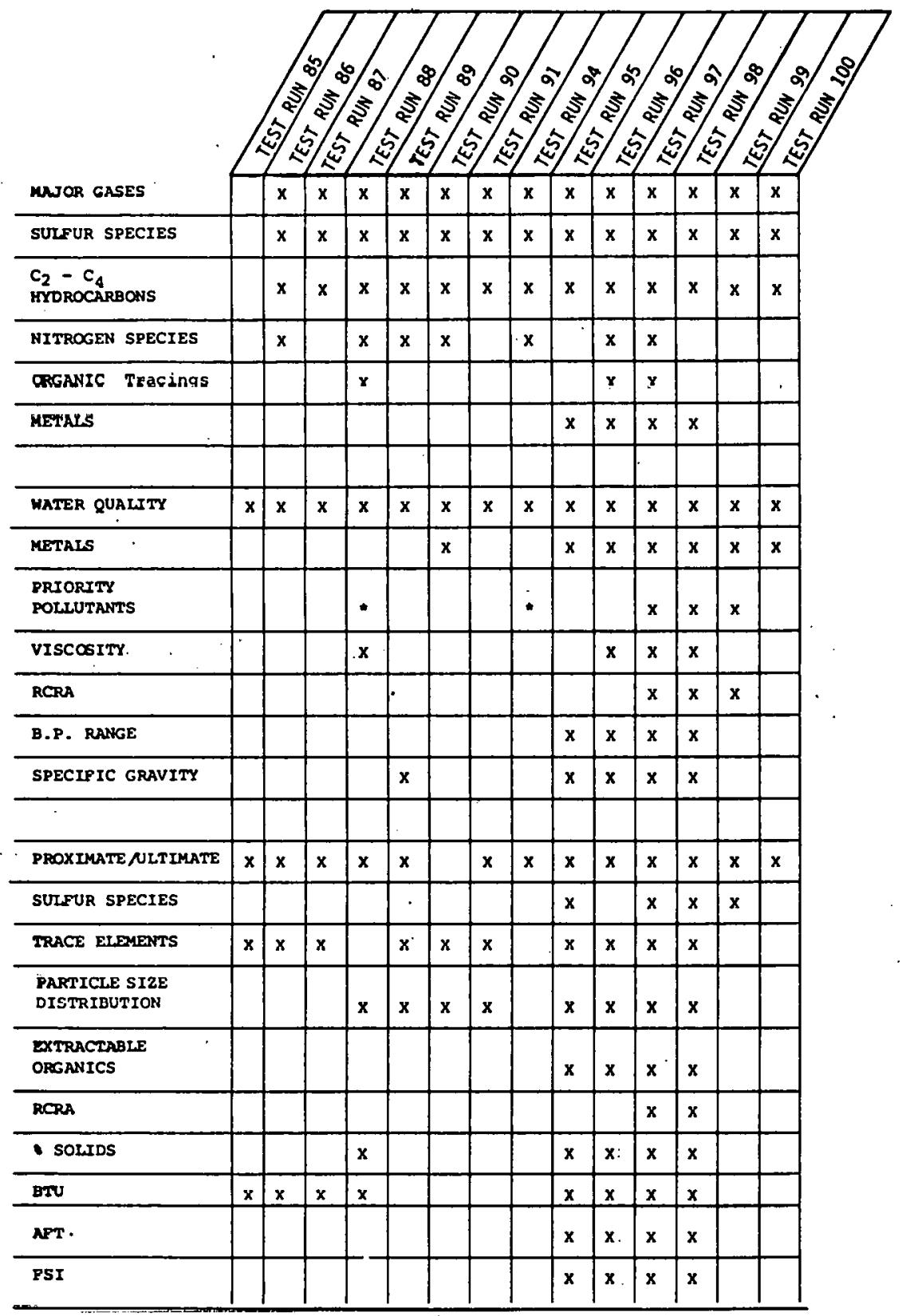

- Selected Parameters only 


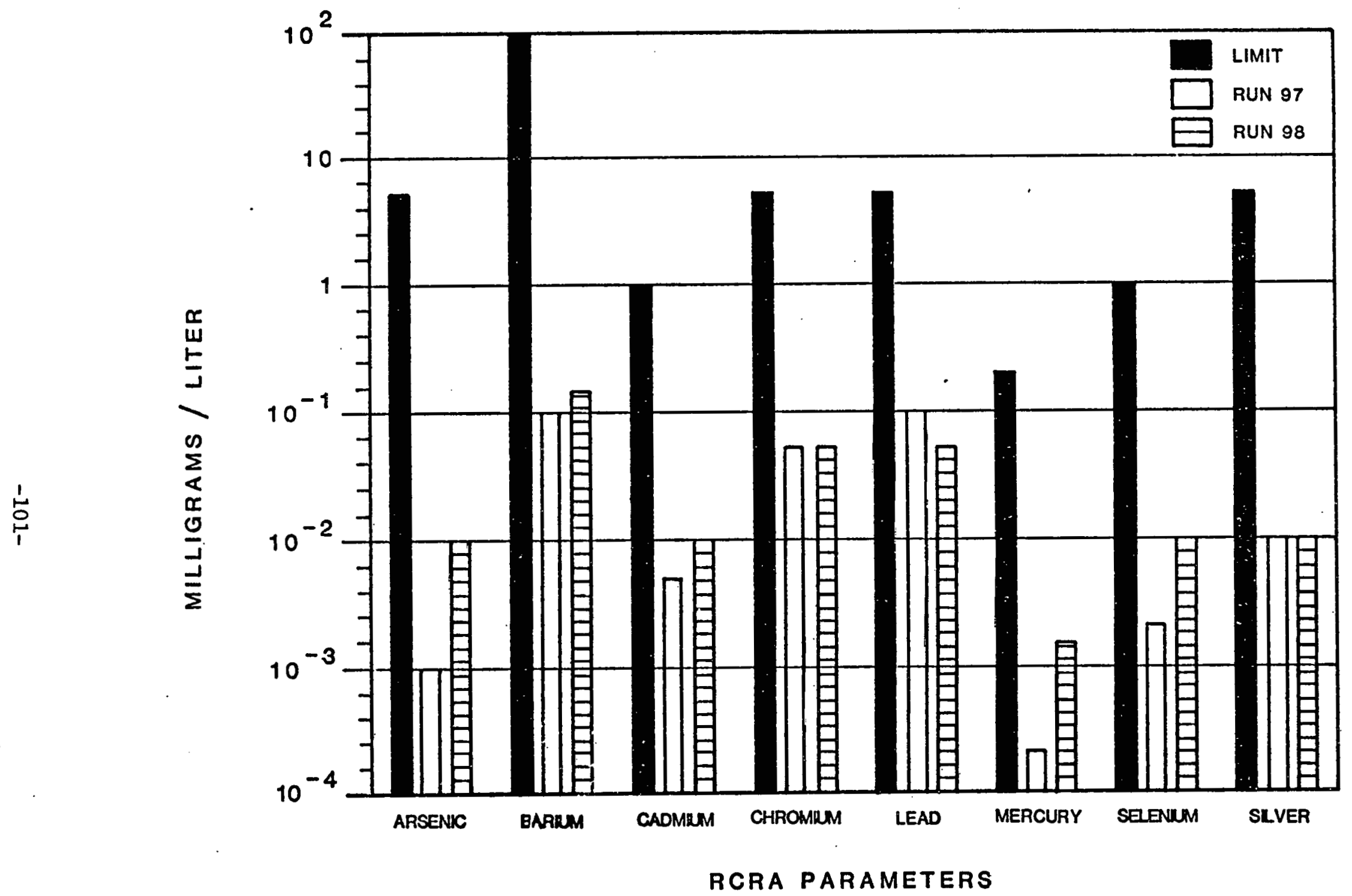

FIGURE 26. COMPARISON OF MEASURED RCRA PARAMETERS IN GASIFIER ASH WITH LIMITS FOR METC FIXED-BED GASIFICATION - RUNS 97 and 98 (BITUMINOUS COAL) 
operation were determined, and a data base of potential contaminants found at coal conversion facilities of this type was begun. Workplace health activities are documented in Table 38. Findings of the HHAS indicate that parameters measured were below permissible exposure limits with one exception (personal samples for coal tar pitch volatiles as measured while tightening the stirrer shaft seal packing gland); no significant occupational clinical abnormalities were observed; and no dermatological problems existed from skin exposures to coal tar pitch volatiles during operation and maintenance activities. As a result of the HHAS, METC adopted workplace health procedures to further minimize exposures. Workplace safety and health monitoring and clinical occupational medical observations will continue in subsequent test runs.

METC gasifier wastewater streams have been characterized to determine principal components significant to treatability. Major wastewater streams include process condensate and ash quench water. Streams have been characterized to determine constituents significant to wastewater treatability. Results indicate that the process condensate is a high strength wastewater containing significant levels of phenol, cyanide, COD, and ammonia (Table 39). Ash quench wastewater is a dilute stream, with concentrations of phenol, thiocyanate, and ammonia which are typically less than $1 \mathrm{mg} / 1,5 \mathrm{mg} / 1$, and $10 \mathrm{mg} / 1$, respective1y. Wastewater characterization efforts initiated with Test Run 96 have provided data used to define influent water quality parameters for the design of a wastewater treatment plant for the METC site. Facility construction is scheduled for FY84.

Workplace Health \& Safety. Once potential hazards are identified, engineering measures can be taken to minimize potential hazards to the worker. Appropriate industrial hygiene procedures have been instituted to reduce employee exposure to potentially harmful materials. This includes a respiratory protection program which was developed for controlling worker exposure in those environments identified as potentially hazardous. In addition, procedures have been developed for the personal use of protective clothing. Noise monitoring has also been conducted. In addition, air samples were collected to assess employee exposures and area levels of a variety of toxic gases, tar vapors, and particulate materials; urine and hlond samples were tcsted for the metabolites of exposed materials; blood assays were made for indicators of tissue damages; skin examinations were made; and potable water was sampled.

Gasifier personnel have carried sampling monitors to measure their 8-hour time-weighted average exposure to materials such as carbon monoxide, hydrogen sulfide, xylene, benzene, toluene, o-toluidineanisidine, cadmium, arsenic, vanadium, lead, hexovalent chromium, total chromium, coal tar pitch volatiles, and a variety of aromatic amines, alcohols, and PNAs.

During monitoring for several constituents typically generated by fixed-bed gasifiers, high levels of coal tar pitch volatiles (CTPV) were identified. Levels exceeded the 8-hour time-weighted threshold limit value. It was recognized that the effluent materials in the drums below the lockhopper discharge points were releasing gases dissolved during the previously pressurized state. Accordingly, a ventilation system incorporating hoods at all 


\section{TABLE 38. WORKPLACE HEALTH ACTIVITES}

METC Gasifter Test Run

95

97

98

99

\section{Activities/Accomplishments}

- Conducted personal and area air sampling for vanadium, nickel, and benzene solubles; concentrations observed were below chemical detection limits.

- Inttiated Health Hazard Assessment.

- Conducted personal and area samples for benzene, toluene, xylene, anisidine, o-toluidine, chromium, nickel, vanadium, cadmium, coal tar pitch volatiles and cresols. Concentrations of coal tar pitch volatiles exceeded standards.

- Biological samples were collected to assess levels of benzene metabolites in the urine of gasifier workers.

- NIOSH was requested to assist in conducting the Health Hazard Assessment.

- Conducted personal and area samples for vanadium, nickel, cadnium, chromium, coal tar pitch volatiles, and selected aromatic hydrocarbons, aromatic amines, and aromatic alcohols. Only two exposures above the standard for coal tar pitch vólatiles were observed.

- Body burden studies were conducted to determine levels of selected trace metals and benzene metabolites in the urine. Blood analyses for selected compounds and metabolities in addition to the urine analyses and clinical function tests.

- Oak Ridge Mational Laboratory (ORNL) tested the operation of several industrial hygiene monitoring instruments being developed by ORNL to obtain testing experience in actual field operating situations and to develop information characterizing the workplace exposure experienced at METC. The instruments involved included the Derivative Uitraviolet Absorption Spectrometer (DUVAS), the Light Pipe Luminoscope, the Spill Spotter, and a Passive Organic Vapor Sampler.

- The health hazam assessment conducted by EG\&G and NIOSH continued. Samples were collected for the same parameters as those collected for Run No. 97

- Wipe samples were collected to define skin contamination and personal protective equipment/barrier effectiveness.

- Area samples were collected for selected aromatic amines, aromatic alcohois, aromatic hydrocarbons, and coal tar pitch volatiles to define ambient background levels of these chemicals.

- Biological samples were collected to assess levels of benzene metabolites in the urine of METC \& EG\&G gasifier workers and a group of EG\&G/METC controls.

- Industrial hygiene activities were not conducted during this run due to the short duration of this run. 
TABLE 39. SUMMARY OF PR.JCESS CONDENSATE CHARACTERIZATION AND NORMALIZED POLLUTANT PRODUCTION

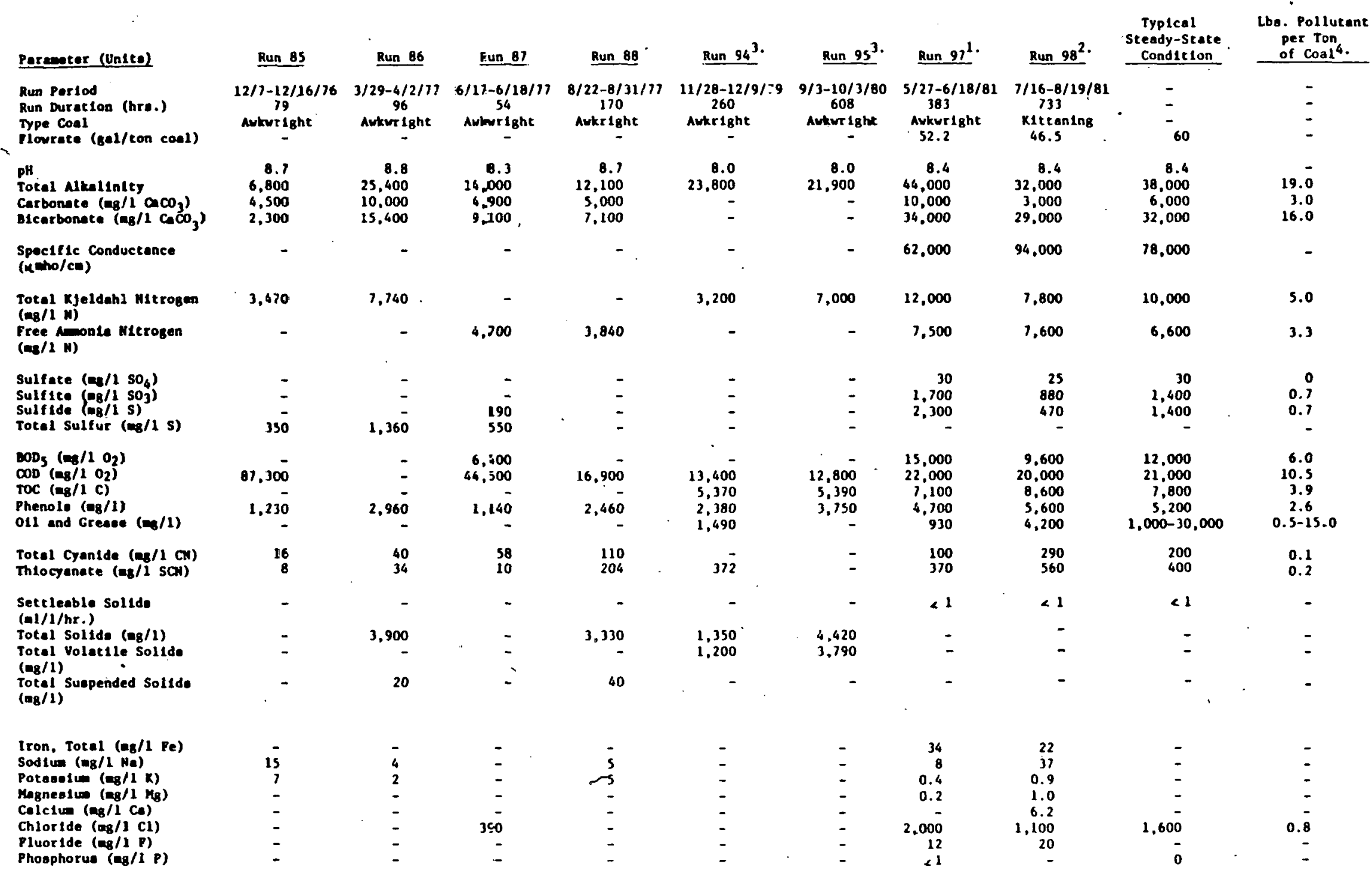

1. Resulte fron 6/16/81 sample.

2. Reoulte froe $8 / 4 / 81$ semple.

3. Reaults from Heufeld et.al. for drumed wate fram Huns 94 and 95 ; date of sample collectiou unkroun.

4. Based on "Typical" steady-gtate consentrations and a wastewater generallon rate of 60 gnilous per ton of coal. 
discharge points was installed to remove potentially harmful offgasses from ground level discharge points. These gases are now combusted in the incinerator. Follow-up monitoring has shown that the ventilation system is effective in significantly reducing. CTPV below the required limit.

Environmental Controls Systems Analysis. Synergism of process and environmental data has resulted in several critical analyses. A detailed description of these activities will be published in a separate environmental R\&D document. Table 39 shows a summary of aqueous pollutant characterizations for eight test runs along with a normalized pollutant production analysis. Such information is useful for scaleup calculations, and for loadings analysis of unit operations in downstream wastewater treatment.

Similar efforts were conducted for pollutants in the gas phase. Pollutant concentration measurements and distribution characteristics were measured. As shown in Table 40, such analyses not only provide a comparison point for compliance purposes (fourth column), but al so contribute towards assessment of the feasibility of gas turbine and fuel cell technologies.

\subsubsection{CHEMICAL ANALYSIS DATA BASE}

Techniques have been developed at METC to characterize the major, minor, and trace components in gas streams. The identification and measurement of trace components and contaminants entailed modification and/or development of new analytical methods and their validation in the field environment. Techniques for the extractive measurement of the major and minor species were developed in phases over the past several years. METC is now examining in-situ, real-time measurement of loading and distribution of trace constituents (i.e., heavy metals, high molecular weight hydrocarbons, sulfur, and nitrogen species). Sampling techniques were first developed, then refinements were made to enhance the precision of the results. Samples. collected at operating pressure were found to differ from those collected at atmospheric pressure. A complete listing of the compounds identified in the cleaned product gas at 200 psig is presented in Lamey, Kovach, and Childers (January 1983). Specifically, the higher-molecular-weight hydrocarbons contained in the clean, low-Btu gas are primarily benzenes and naphthalenes with some furans and thiophenes. Furthermore:

- Most of the components present are substituted benzenes.

- The naphthalene and substituted naphthalenes are present in only trace amounts.

- A number of aromatics contain sulfur and oxygen (thiophenes and furans).

- Several low-molecular-weight, non-aromatic gases are present.

- A series of straight chain and branched aliphatic compounds is present, from $n$-heptane to undecane. More than 20 compounds of these types were found. It is likely that these components are from kerosene which was added to the system to wash the electrostatic precipitator during this test. 
TABLE 40. CONTAMINANT LEVELS IN THE METC FIXED-BED GASIFIER PRODUCT GAS

\begin{tabular}{|c|c|c|c|c|c|}
\hline \multirow{2}{*}{$\begin{array}{l}\text { CONTAMINANT } \\
\text { SPECIES }\end{array}$} & \multicolumn{2}{|c|}{ PRCDUCT GAS STREAM } & \multicolumn{3}{|c|}{ ALLOWABLE LIMITS } \\
\hline & GASIFIER EXIT & CLEANED GAS & ENVIROHMENTAL & GAS TURBINE & FUEL CELL \\
\hline Sulfur Compounds & 4000 prm & $<10 \mathrm{ppm}$ as $\mathrm{H}_{2} \mathrm{~S}$ & $\begin{array}{l}260 \mathrm{ppm} \text { as } \mathrm{H}_{2} \mathrm{~S} \\
\text { (EPA: ior SO? }\end{array}$ & -- & $1 \mathrm{ppm}$. \\
\hline Nitrogen as $\mathrm{NH}_{3}$ & $2300 \mathrm{pFm}$ & $<30 \mathrm{ppm}$ & $\begin{array}{l}350 \mathrm{ppm} \mathrm{NH}_{3} \\
\text { (EPA: for } \mathrm{NO}_{2} \text { ) }\end{array}$ & - - & 7 \\
\hline Total $\mathrm{Na}+\mathrm{K}$ & $6000 \mathrm{prm}$ & $<10 \mathrm{ppb}$ & - & $0.1 \mathrm{ppm}$ & -- \\
\hline $\begin{array}{l}\text { Hydrocarbons } \\
\text { (Tars) }\end{array}$ & $8400 \mathrm{prm}$ & $<350 \mathrm{ppm}$ & $\begin{array}{l}\text { Various (EPA: } \\
\text { lowest MATE**) }\end{array}$ & -- & $<100$ ppm \\
\hline Particulate & 7700 pFm & $<1 \mathrm{ppm}$ & $\begin{array}{l}50 \text { ppm (EPA: } \\
\text { Coal Burning } \\
\text { Plant) }\end{array}$ & $\begin{array}{l}\approx 0 \mathrm{ppm} \theta>10 \mu \mathrm{m}^{\star} \\
<20 \mathrm{ppm} \propto 2-10 \mu \mathrm{m}^{*}\end{array}$ & $?$ \\
\hline
\end{tabular}

* Applicable only to products of combustion, not to fuel gas

** Minimum Acute Toxic Effluent 
- The largest individual components listed in descending order are: 1,4-Dimethylbenzene > 1,3-Dimethylbenzene > 1,2-Dimethylbenzene > Indene > 1-Ethy 1-2-Methylbenzene > 1,2,4-Trimethylbenzene.

Under contract to METC, Ames Labs of Iowa State University has developed on-line atomic emission analyzers to detect and measure alkali metals and heavy metals in the gas. The alkali metal monitor was developed and tested at METC and showed good agreement with much slower alternative methods. Testing of the so-called "Ames meter" was conducted during Test Runs 95 through 99 . Very low levels of alkali were found to be present in the cleaned product gas. Current activities include modifications to allow testing at sample locations where the gas has not been cleaned. This will assist in determining the distribution of metals as they progress through the cleanup system. Further development is required to improve the sensitivity of the heavy metals analyzer.

As part of a cooperative METC program with DOE's Office of Energy Research, Lovelace Labs of ITRI developed methods for measuring high and low temperature aerosols. These aerosols were analyzed for dust and hydrocarbon content; characterization of aerosols with mean diameters below 10 microns was achieved. Results were compared with METC analytical techniques and showed good agreement. Development and further field testing will continue.

Aerosol measurements in the gas were made using techniques developed in conjunction with ITRI. Initial test work was conducted on the side-stream during Test Runs 86 through 91. These tests keyed on development and refinement of the analytical techniques. During Test Runs 91 through 94 , measurements of the aerosol mass loadings were made on the side-stream and on the humidifier and tar separator outlet. High-temperature/high-pressure measurements were made during Test Run 95. During this test, the gasifier outlet, humidifier outlet, and tar separator outlet were characterized for aerosol loading. Characterization of the clean product gas was performed for aerosols and high molecular weight hydrocarbons. During Test Runs 96 through 98, aerosol measurements were primarily made in the clean product gas. The purpose of this program was to determine the ultimate fate of the aerosol components as the gas passed sequentially through the cleaning process.

The distribution and size of aerosols as they pass from the gasifier through the cleanup system and of those contained in the final product gas are represented in Figure 27. This figure summarizes the results of many of these studies. A detailed description of these data can be found in ITRI reports (December 1979, 1980,.1981, and 1982).

The CARS system is being developed and tested in conjunction with Los Alamos National Laboratory (LANL) to measure gas compositions in hot, dirty gas streams. The CARS system consists of two laser beams that can be blended to produce a third beam. This third beam is then passed through the gas stream via optical ports at the cyclone outlet. By using the two laser beams of different frequencies, CARS is able to tune onto the frequencies of the gas molecules of interest.

During Run 99, the CARS system was operated at the cyclone outlet. The tar vapor, as anticipated, had an opaqueness that resulted in scatter of the tuned laser beam; however, sufficient energy was passed through the pipe so that a 


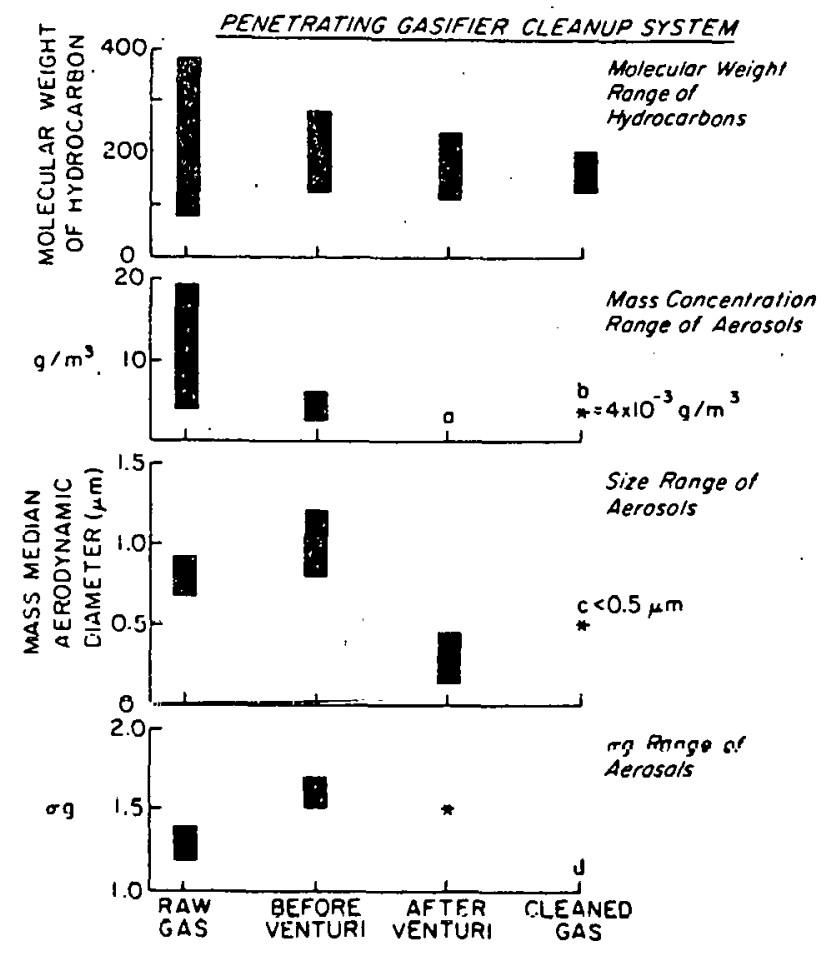

Molecular weight ranges of hydrocarbons, range of distribution parameters and mass loading penetrating the cleanup system on the Morgantown Energy Technology Center low Btu coal gasifier during Decemher 1979 tests $\mathrm{s}^{3}$
* Single measurement, (a) dilution ratio unknown, (b) $4.0 \times 10^{-3} \mathrm{gm} / \mathrm{m}^{3}$ (c) all mass collected on final filter of cascade impactor and therefore $M M A D^{\star}<0.5 \mu \mathrm{m},(d)$. no measurement obtained. These analyses performed by ITRI sampling and analysis systems.

*MMAD $=$ Mass Medium Aerodynamic Diameter

FIGURE 27. DISTRIBUTION AND SIZE OF AEROSOLS THROUGHOUT PROCESS GAS STREAMS 
usable signal was obtained. The CARS system determined in-situ concentrations of nitrogen, carbon dioxide, carbon monoxide, and hydrogen sulfide; these concentrations agreed with recorded gas chromatography data. This was the initial test on the METC gasifier, and the CARS results were extremely encouraging. The purge and optical access port was reconfigured to minimize deposition so that access to the process can be extended before the windows require cleaning.

The LIBS system, also being developed in conjunction with LANL, uses a single laser focused through optical windows into the gas stream to create a plasma. This plasma acts as an excitation source, and the light emitted is analyzed. From the intensity of the emitted radiation at characteristic wavelengths, the concentration of elements of interest can be determined. The LIBS system was installed on the METC gasifier to analyze the final product gas.

Testing of the LIBS system during Run 99 revealed the gas to have cleaner optical properties with no noticeable contaminants. The LIBS system operation showed no detectable concentrations of alkalis. These tests on the LIBS system were run in conjunction with METC's Ames alkali meter, which agreed with the LIBS results. The alkali levels at this point in the process stream were < $20 \mathrm{ppb}$, as determined by a bubbler train. This agreement was reached among three independent techniques. The on-line LIBS measurements have been verified.

The following conclusions drawn from the data developed as a part of this program are described in more detail. in the ITRI reports (December 1979, 1980, 1981 , and 1982.

- The METC cleanup system provides clean low-Btu product gas.

- Diluting and/or cooling low-Btu gas, as might happen in fugitive releases, produces a dense, respirable aerosol.

- Gasifier operating conditions have little effect on the elemental composition of cleaned gas aerosols.

- Gasifier bottom and cyclone ash are similar to coal combustion fly ash.

- Ba and Ge are enriched in small aerosol particles of the cooled and diluted coal gas aerosols.

- $\mathrm{Cl}, \mathrm{I}$, Mo and $\mathrm{Sr}$ are enriched in large aerosol particles $(>\mu 5 \mathrm{~m})$.

- Aerosol particle-phase organic concentration is reduced by the METC cleanup system.

- High molecular weight organic compounds present in the gasifier are primarily aromatic and alkyl-substituted aromatic compounds.

- Cooling and diluting low-Btu coal gas preferentially transfers polynuclear aromatics heavier than 182 atomic mass units (amu) from the vapor to the particle phase. 


\subsubsection{Process Modeling and Simulation}

The process modeling and simulation program, described in Section 4.6, has provided meaningful information for the METC gasification and cleanup system. Current program activities are described below.

Gasifier and Cyclone. The Wen II gasifier model, developed at West Virginia University and enhanced with new coal kinetics data, has been the primary model utilized. It treats the gasifier as a fixed-bed, plug-flow reactor having four reactor regimes: drying (top); devolatilization; gasification; and combustion (bottom). Given coal and gaseous feeds into the reactor, raw product gas temperature, species concentrations, and solids content are predicted. Either the reactor height or the coal carbon conversion efficiency can be specified. - This model can be operated as an ASPEN unit operation block or on a stand-alone basis. Other fixed-bed gasifier models are al so available or are being procured (i.e., TRW, Denn-EPRI, Joseph, Scientific Design Company or SDC). The raw product gas enters a cyclone which is currently being modeled using the cyclone model from the ASPEN unit operations library. Other stand-alone cyclone models al so exist (i.e., METC, GE, Research-Cottrell). The predictions by the Wen 11 gasifier model are used for both oxygen and air-blown gasification operations. Figures 28 and 29 are examples of model predictions for air-and oxygen-blown operations, respectively.

Humidifier. In the humidifier, water is injected to cool incoming gas to about $50^{\circ} \mathrm{F}$ above the dew point. This results in condensation of only heavy tar. A modified version of a humidifier model developed by Physical Science, Inc., (PSI) is being used to simulate its operation. The model uses the simultaneous evaporation of water droplets and condensation of tar droplets, taking into account variations as flow proceeds from the top to the bottom of the humidifier as well as variations along a radial direction. This model has been validated against past operating data and has been "ASPENized" (modified for incorporation into the ASPEN unit operations libraryl. The humidifier model has been very useful in both design modification studies and process analysis.

An example of humidifier model predictions is given in Figure 30 . Good comparison between measured and predicted humidifier tar removal performance is also demonstrated in Figure 31. Additional details of simulation efforts related to the METC fixed-bed gasification system will be published as a separate document in the near future.

HSDU. A steady-state model of the HSDU was developed at METC. It is a systems model since it does not account for all the complex chemical reactions occurring in the Stretford liquor. The overall HSDU model actually comprises several "sub-models" for the absorber, delay tank, flash tank, oxidizer, and the evaporator. In order to use the model, incoming gas flowrate, temperature, pressure, components concentration, liquor flowrate, equipment sizes, and design must be specified. The model predicts the degree of capture of sulfur compounds from the gas phase and the rate of those compounds after they are absorbed into the Stretford liquor by an extremely fast chemical reaction with sodium carbonate. Depending on the oxidizer operating condition, delay tank capacity, $\mathrm{pH}$, and reaction kinetics, the model predicts the amount of elemental sulfur produced in the HSDU. Since the gas and liquid phase mass 


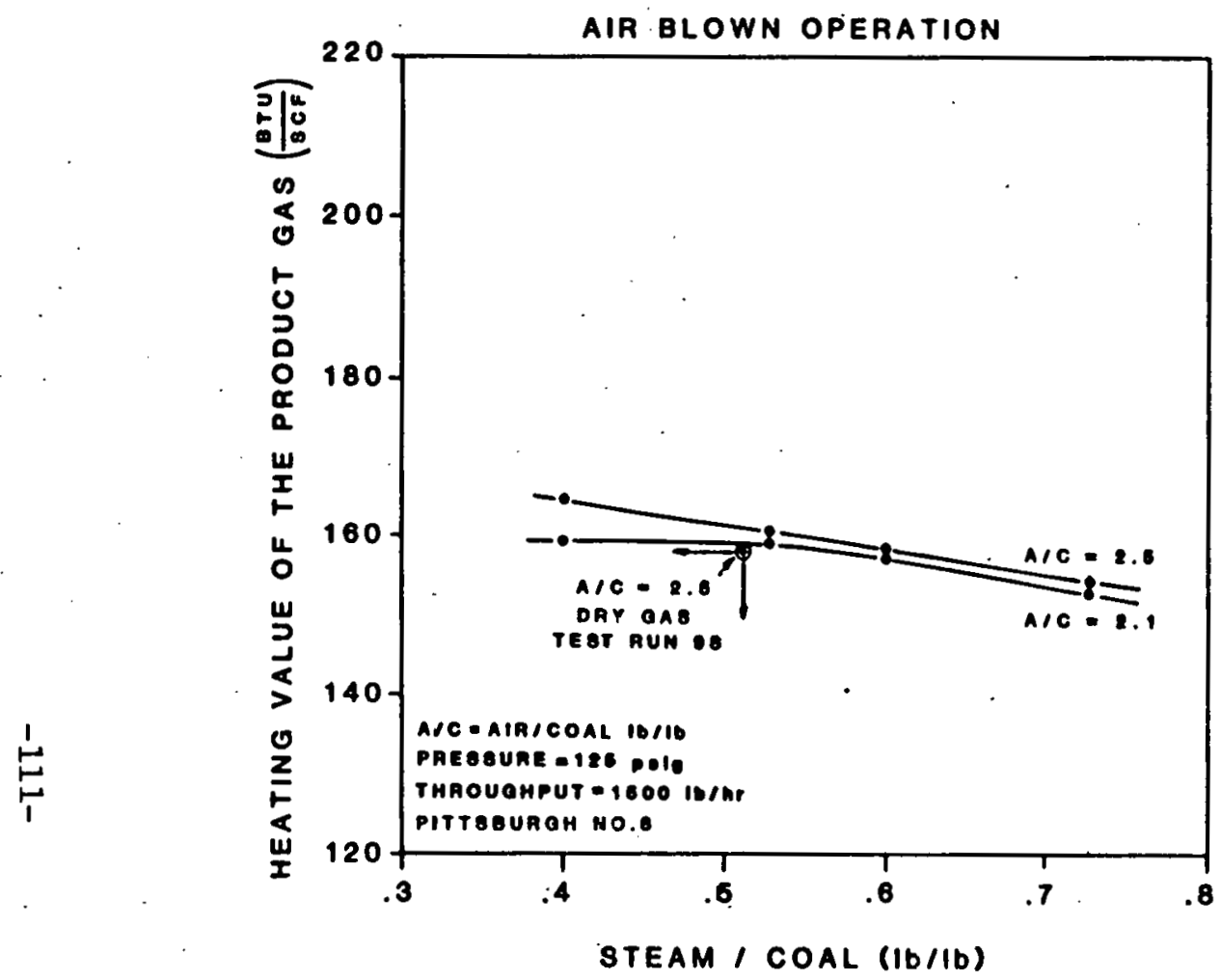

FIGURE 28. PREDICTION OF PRODUCT GAST HEATING VALUE FOR METC FIXED-BED GASIFIER UNDER AIR-BLOWN OPERATION

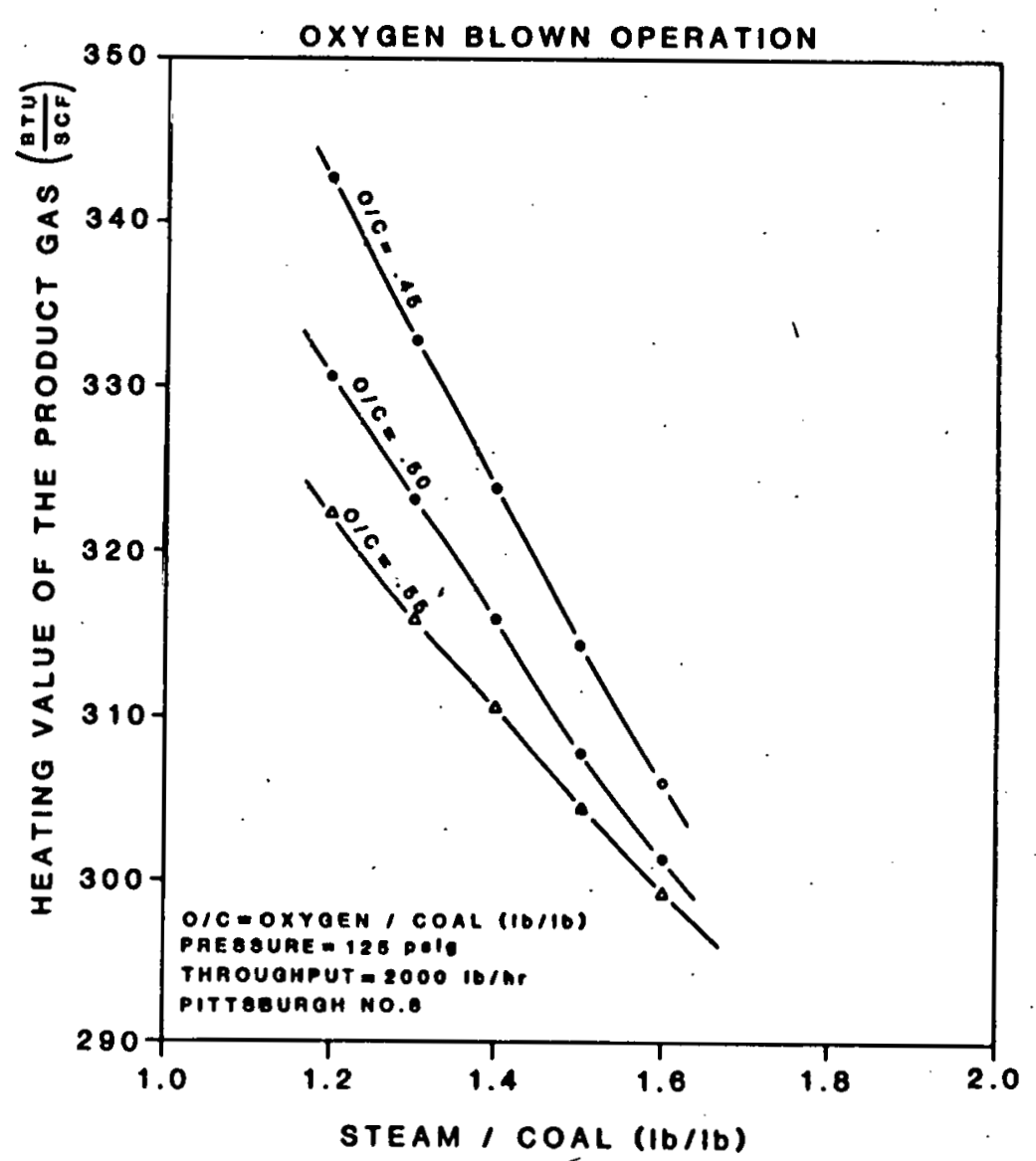

FIGURE 29. PREDICTION OF PRODUCT GAS HEATING VALUE FOR METC FIXED-BED GASIFIER UNDER OXYGEN-BLOWN OPERATION 


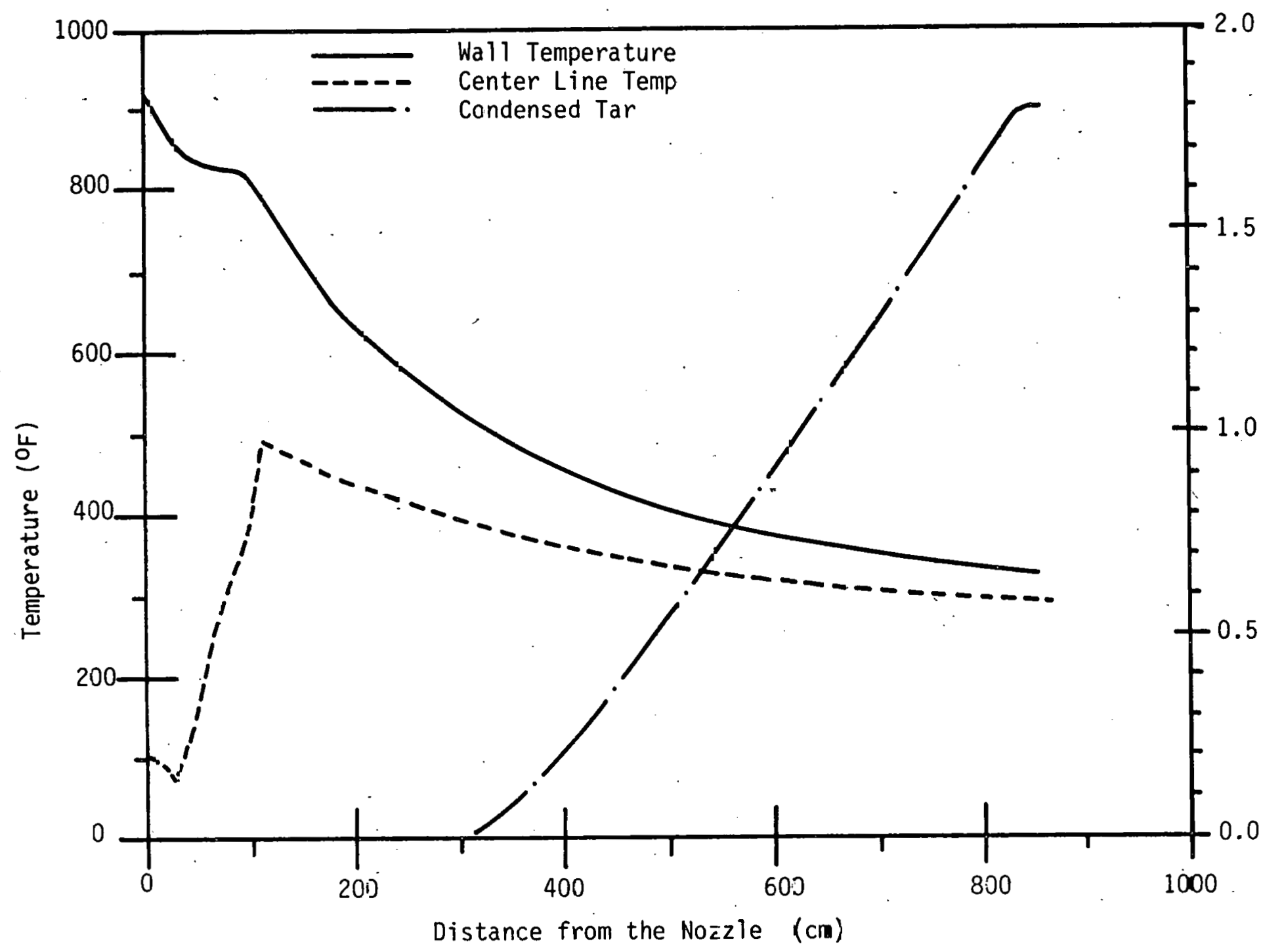

FIGURE 30. MODEL PREDICTION OF HUMIDIFIER WALL TEMPERATURES, TAR CONDENSATION RATE, AND CENTER LINE TEMPERATURES AS A FUNCTION OF HEIGHT 


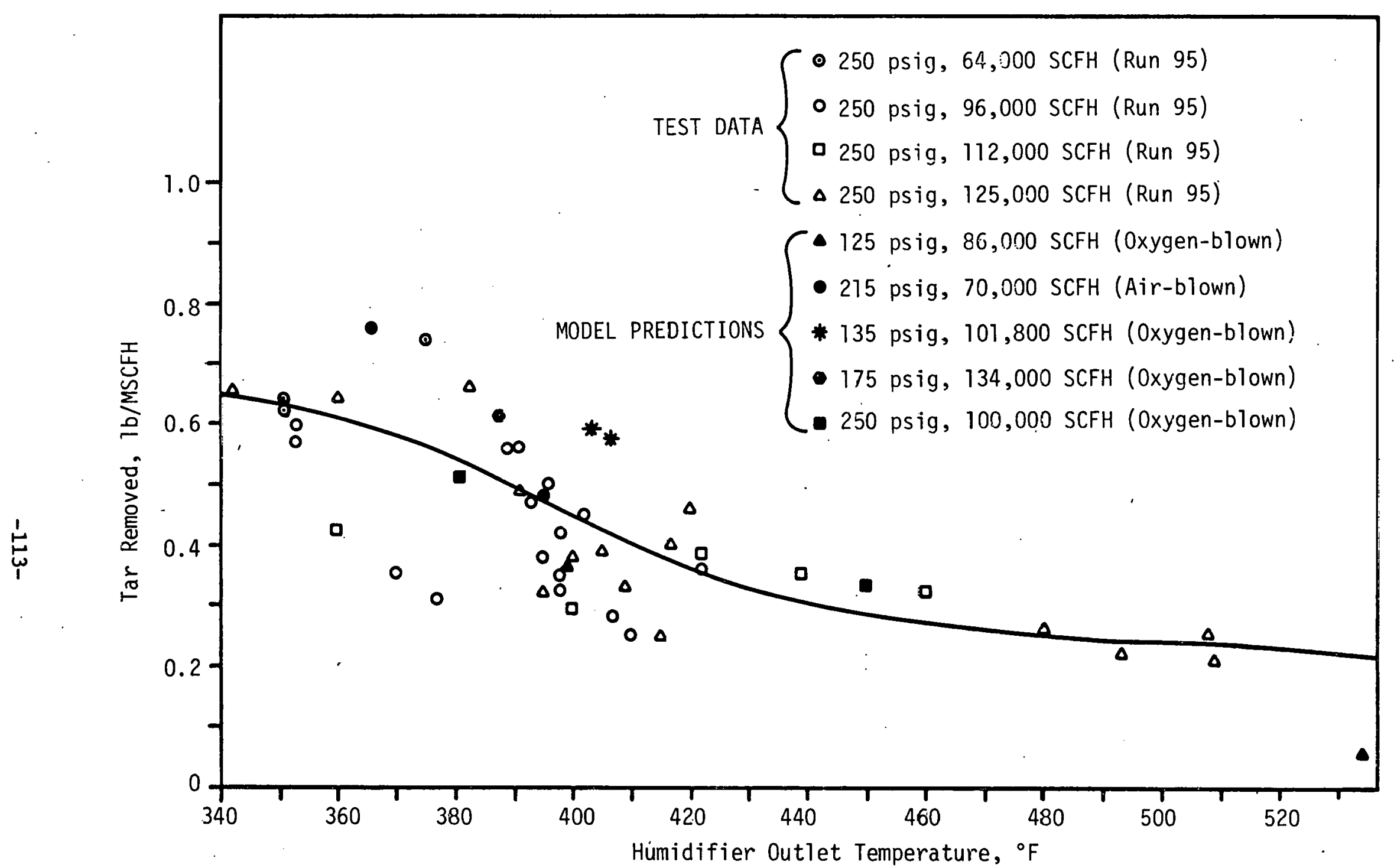

FIGURE 31. COMPARISON OF MODEL PREDICTIONS AND TEST DATA FOR THE METC FIXED-BED GASIFICATION HUMIOIFIER 
transfer coefficients for the absorber and oxidizer were backed out of empirical HSDU data from past runs, the Stretford model is currently restricted to the METC process unit. Efforts are ongoing to better characterize the liquor chemistry and HSDU rate phenomena. This should result in a METCspecific computer model. This model is currently used as an ASPEN model, as. well as a stand-alone model.

Systems Analysis - Gasifier and Full-Flow Cleanup. Integrated steady-state simulation of the overall process, including the gasifier and all elements of the cleanup system, was conducted using ASPEN. Figure 32 is an example of an ASPEN process simulation flowsheet (generated automatically on an ASPEN graphical flowsheet generator) used to perform an overall integrated simulation of the METC fixed-bed coal gasification system. Dynamic simulation of the process was planned for late FY83.

\subsubsection{In-Service Valve Test Program}

The overall valve testing program has tested over 20 different types of lockhopper valves in the valve testing facility at METC. These have been tested in both static and flowing conditions. The results of the tests are described in METC reports (July 1980, and October 15-17, 1980). For the in-service valve test program on the gasifier, Kamyr valves were chosen to be installed as lockhopper valves for the coal and ash hoppers on the METC fixed-bed gasifier. In 1976, when the State-of-the-Art (SOA) Lockhopper Valve Testing and Development Project was initiated, the maximum process condition for a lockhopper valve was a differential pressure of $500 \mathrm{psi}$ at an operating temperature of $600^{\circ} \mathrm{F}$. To maintain acceptable performance at this condition, the valve has to be rebuilt approximately every 500 cycles. Prior to installation gas leakrate for these valves was measured to be approximately 0.05 standard cubic feet per day (SCFD) at operating temperatures and pressures. In the METC stirred fixed-bed gasifier, feed lockhopper valves are now operating for 4,500 cycles at pressures of 165 psig with estimated temperatures of $450^{\circ} \mathrm{F}$; cyclone dust removal lockhopper valves have been operated successfully for over 4,500 cycles with $500^{\circ}$ to $700^{\circ} \mathrm{F}$ solids. SOA test valves have performed well in simulated lockhopper conditions for over 16,000 cycles at pressures to $1,000 \mathrm{psig}$ and valve body temperatures to $600^{\circ} \mathrm{F}$. This represents a significant improvement since the start of the project. It is believed that valves with a reliable service life of 15,000 cycles at $1,000 \mathrm{psig}$ and $1000^{\circ} \mathrm{F}$ can be purchased.

Activities currently in progress include compiling valve inspection data related to the METC fixed-bed gasifier for evaluation and issuance as a separate report.

\subsubsection{Corrosion/Erosion Test Program}

The Ceramics Corrosion/Erosion study's main objective was to conduct a screening test for several ceramic materials to assess their probability of survival in turbine applications. The materials were exposed to combustion products from low heating value coal-derived gas and air at several high temperatures and gas flow velocities. The combustion product composition and temperatures simulated the actual environment found in stationary power-generating gas turbines except for the pressure levels. The results of approximately 1000 hours of testing are summarized. Detailed description of the test results can be found in Nakaishi's report (May 1982). 


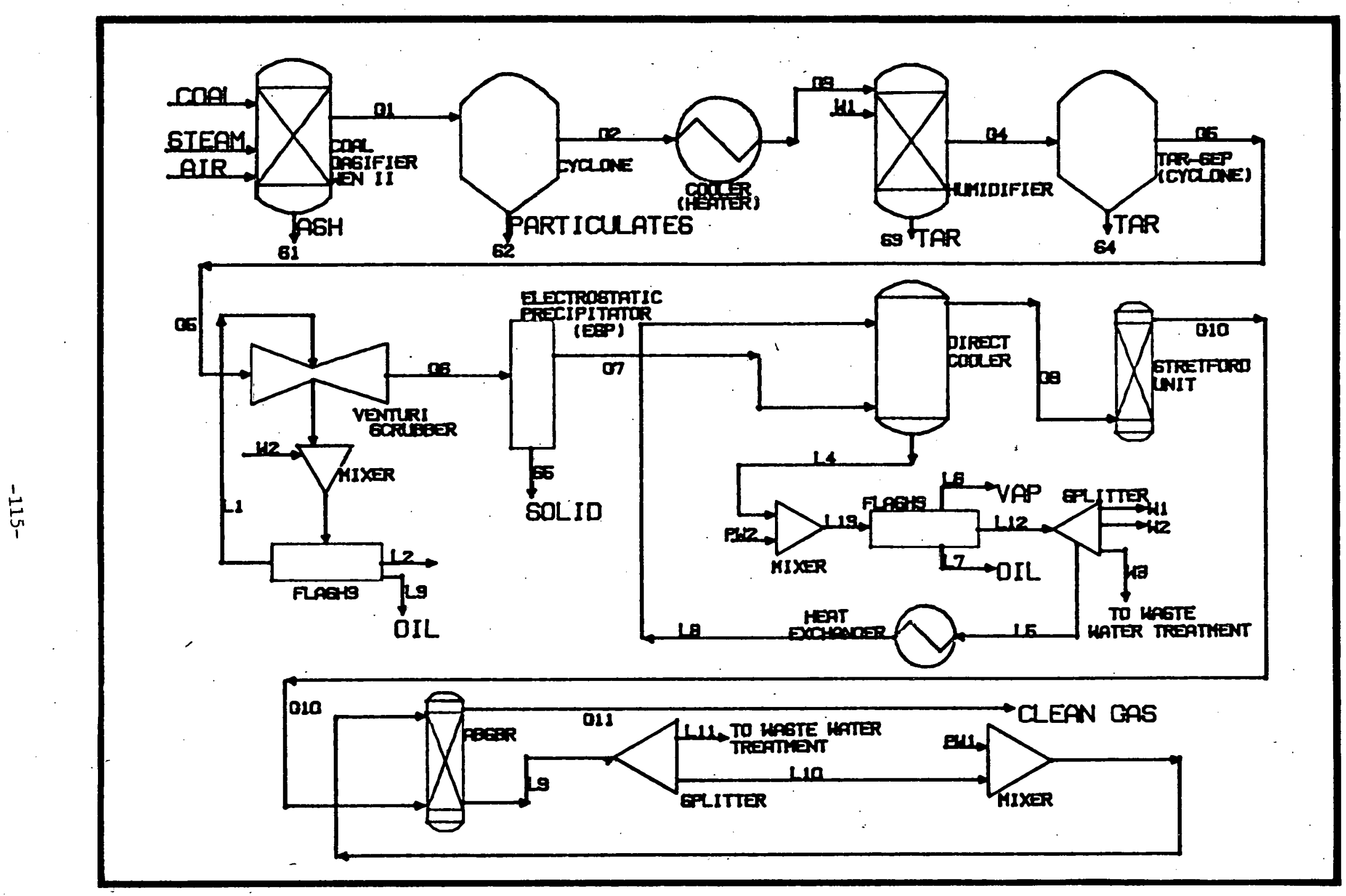

FIGURE 32. COMPUTERIZED ASPEN PROCESS FLOW SHEET INPUT FOR METC FIXED-BED COAL GASIFICATION SYSTEM 
Two separate test units were used, one providing near-static, low-velocity combustion products, and the other providing dynamic, high-velocity combustion products. Both units were operated simultaneously using a common fuel gas source. The static unit operating conditions in its three different test cells were: (1) separate temperatures of $1850^{\circ}, 2200^{\circ}$, and $2600^{\circ} \mathrm{F}$; (2) exposure durations of 100,300 , and 1000 hours; and (3) combustion product velocities of less than $10 \mathrm{ft} / \mathrm{sec}$. The test conditions for the dynamic unit were: (1) a single temperature of $2600^{\circ} \mathrm{F}$; (2) a duration of 1000 hours; and (3) combustion product velocity of $1000 \mathrm{ft} / \mathrm{sec}$. The test units are shown in Figure 14 in Section 4 of this report. The "dynamic" test should give an indication of the combined corrosive/erosive effects while the "static" test should indicate corrosive effects. A comparison of both tests should give a measure of each effect on the ceramic specimens, and should help eliminate materials that are not suited for use in a high-temperature, coal-derived combustion gas environment. An extensive characterization of the combustion environment was made during these tests, and the results are summarized in Table 41 .

The static unit consisted of three separate test cells. Each cell had the capacity of exposing two racks of specimens simultaneously. Each rack had a duplication of four individual specimens of each of the 14 different material types (504 total specimens). At the start, each cell was loaded with the racks scheduled for 1000 and 100 hours of exposure. After the first phase, the 100-hour racks were replaced by racks scheduled for 300 hours of exposure. Finally, after Phase II ( 400 hours), the 300-hour racks were removed leaving only the three racks scheduled for the full 1000 hours of exposure. This totaled nine test racks. The durations of exposure times and the specimen arrangement on the nine racks are described in Nakaishi's report (May 1982). Table 42 is a listing of the materials tested in the corrosion/erosion facilities.

The dynamic unit consisted of a single test section operating at a nominal temperature of $2600^{\circ} \mathrm{F}$. The combustion products velocity across the specimens was designed to be $1000 \mathrm{ft} / \mathrm{sec}$. Velocity at this temperature equals Mach 0.4 . This unit could accommodate only 12 individual specimens simultaneously, and only 11 of the total 14 material types were tested in this unit. These dynamic test specimens were scheduled to be exposed for the entire 1000 hours. However, specimens were replaced during the test if they failed catastrophically, e.g., came out of their holders, broke off, or were excessively degraded (unless their distortion prevented removal). Most of the specimens, when removed at the end of the test period, showed signs of material removal from their upstream surfaces. An accurate measurement of material degradation is being made by the Illinois ITRI. A final report documenting the material characterization from both test units and their correlation is expected to be issued soon. 
TABLE 41.

DESCRIPTION OF THE PRODUCTS OF COMBUSTION, CORROSION/EROSION TEST FACILITY

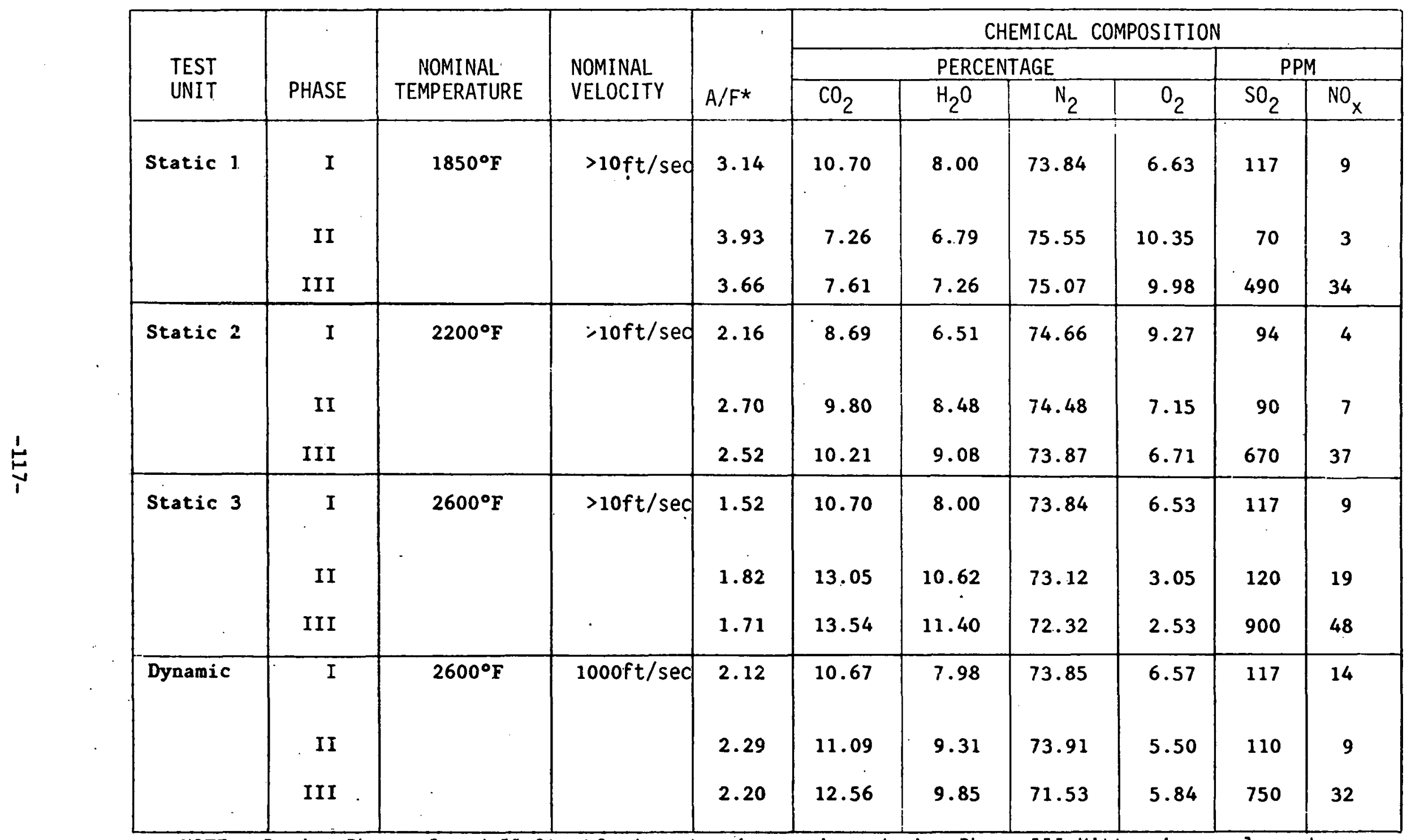

NOTE: During Phases I and II Stretford system in service; during Phase III Kittanning coal used and Stretford system bypassed.

Ref.: DOE/METC-82-46

* Air to Fuel Ratio 
TABLE 42.

TEST SPECIMEN MATERIAL AND VENDORS

CORROSION/EROSION TEST PROGRAM

\begin{tabular}{|c|c|}
\hline VENDOR & DESCRIPTION \\
\hline 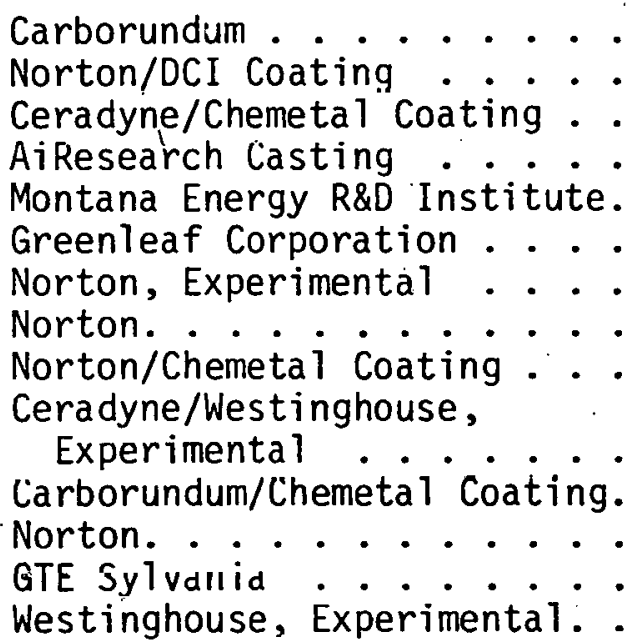 & 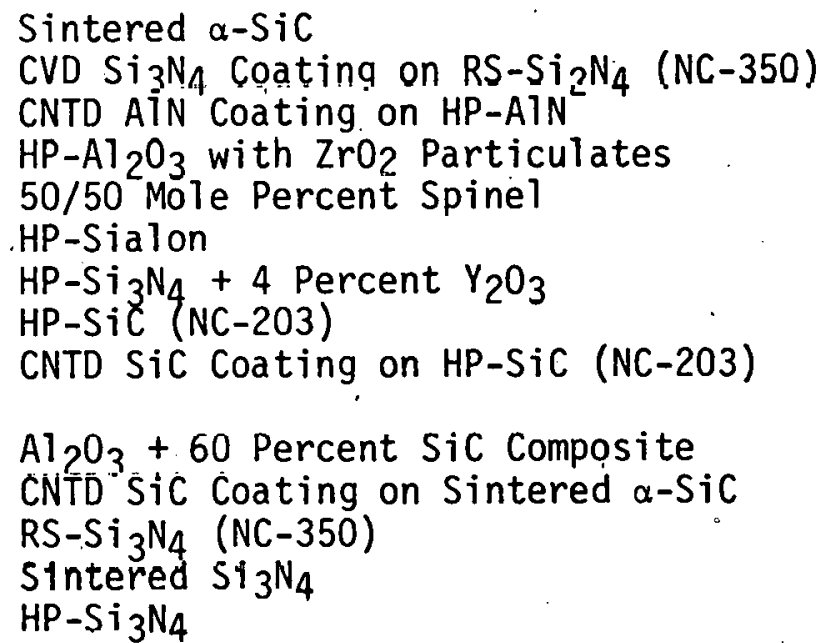 \\
\hline
\end{tabular}

Ref: DOE/METC-82-46 


\begin{tabular}{|c|c|c|}
\hline $\begin{array}{l}\text { ADA } \\
\text { ADACS } \\
\text { A/F } \\
\text { AFT } \\
\text { amu } \\
\text { ANL } \\
\text { ASPEN } \\
\text { BOD } \\
\text { Btu } \\
\text { Btu/Ib } \\
\text { Btu/SCF } \\
\text { CARS } \\
\text { CH } \\
\text { CO } \\
\text { CO } \\
\text { COD } \\
\text { COS } \\
\text { CP } \\
\text { CRT } \\
\text { CS } \\
\text { CTPV } \\
\text { CU ft } \\
\text { CWR } \\
\text { CWS } \\
\text { DOE } \\
\text { DUVAS } \\
\text { EG\&G } \\
\text { EH\&S } \\
\text { EP } \\
\text { EPA } \\
\text { EPRI } \\
\text { ESP } \\
\text { oF } \\
\text { FAI } \\
\text { FFCUS } \\
\text { FQI } \\
\text { FSI } \\
\text { ft/min } \\
\text { ft } / s e C \\
\text { GC } \\
\text { GE } \\
\text { GFETC } \\
\text { gm/m } 3 \\
\text { gPm } \\
\text { GRI } \\
\text { g/sCm } \\
\mathrm{H}_{2} \\
\mathrm{H}_{2} 0 \\
\mathrm{H}_{2} \mathrm{~S} \\
\mathrm{HC} \\
\mathrm{HCV} \\
\end{array}$ & E & 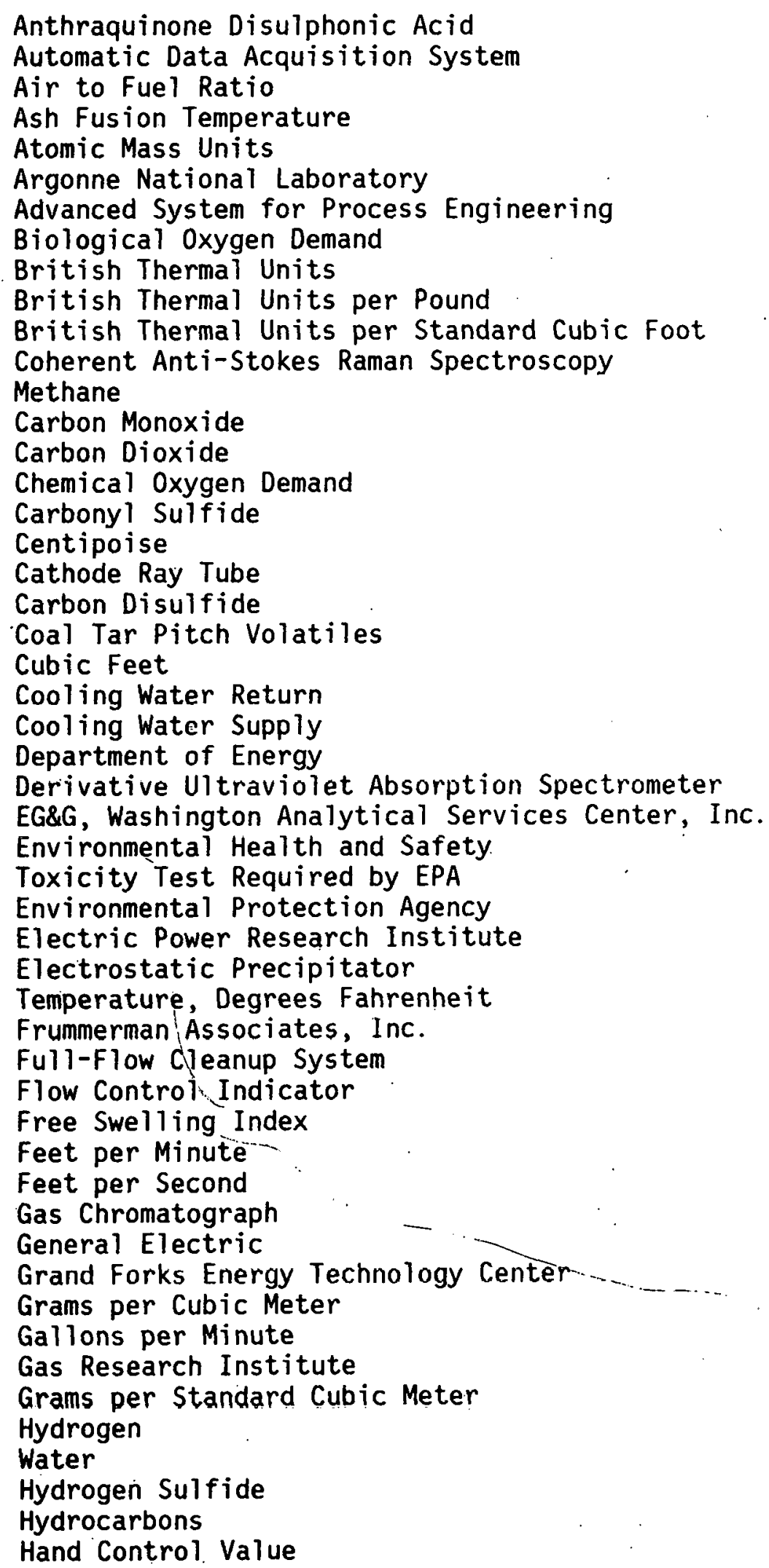 \\
\hline
\end{tabular}

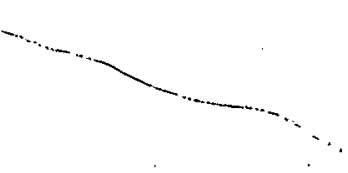




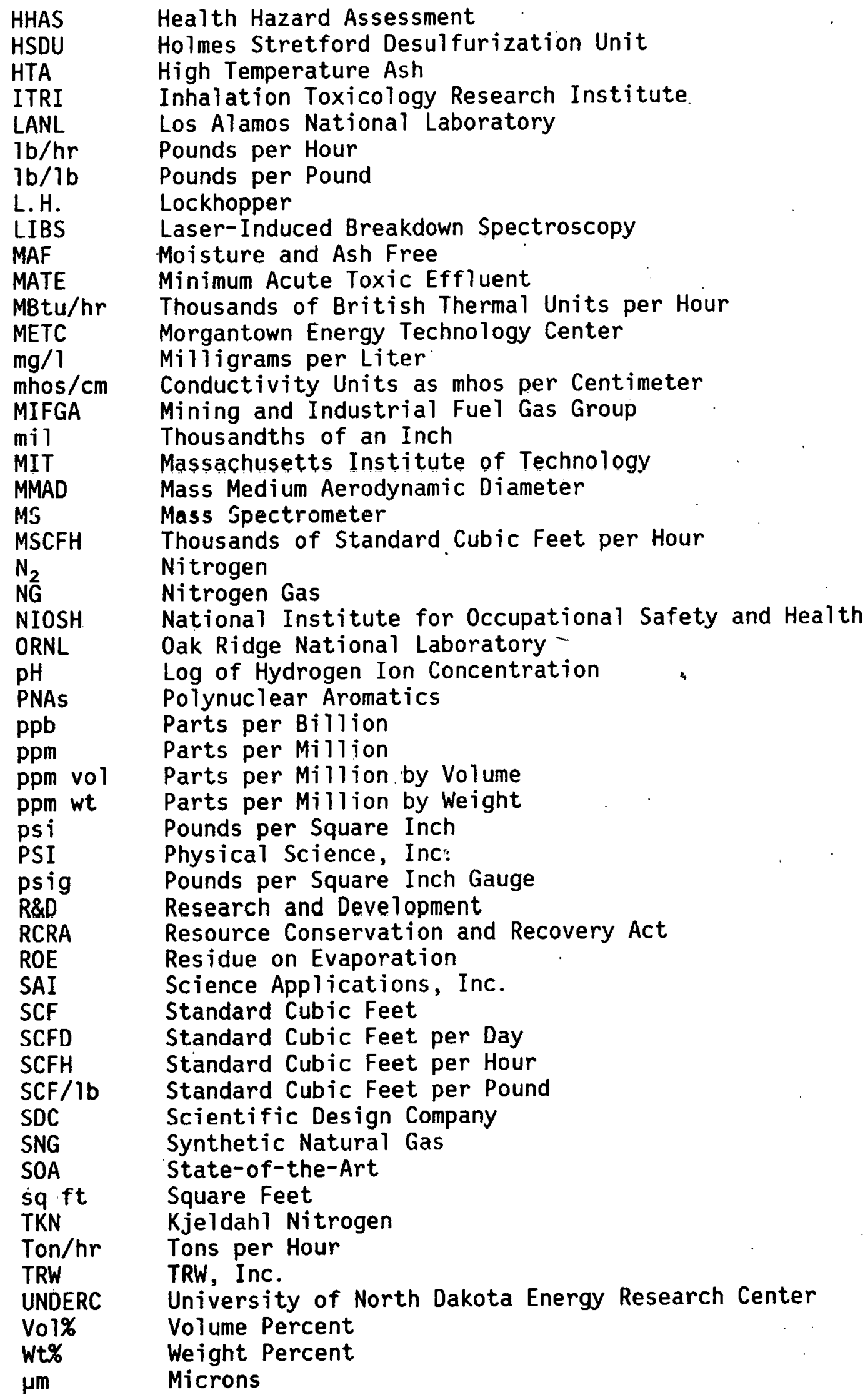




\subsection{REFERENCES}

Day, W. H. 1977. Gas turbine development programs. General Electric.

Inhalation Toxicology Research Institute (ITRI). December 1979. Annual report -- 1978/1979. LF-69/UC-48.

- December 1980. Annual report -- 1979/1980. LF-84/UC-48.

- December 1981. Annual report -- 1980/1981. LF-91/UC-48.

- December 1982. Annual report -- 1981/1982. LF-91/UC-48.

Lamey S., K. McGaskill, and R. Ruth. December 1981. GC/MS characterization of condensable tars in the output stream of a stirred fixed-bed gasifier. DOE/METC/TPR-82/2.

Lamey S., J. Kovach, and E. Childers. January 1983. Hydrocarbon content of the vapor phase and light oil fraction in the output stream of the METC gasifier. DOE/METC/TPR/83-43.

de Lesdernier, D. L., D. J. Stopek, and V. S. Engleman. July 1980. Design of a spinning disk atomizer for gas producer humidifier. Science Applications, Inc.

Lewis P. S., A. J. Liberatore, and J. P. McGee. 1972. Strongly caking coal gasified in a stirred-bed gasifier. U.S. DOE, RI-7644.

Mittelhauser Corporation. August 1980. Review of the METC gasification system.

Moore, A. S., K. Pater, C. Rai, and R. J. Belt. October 1978. Cleaning gasifier gas from the MERC gasifier. Presented at the 13th Intersociety Energy Conversion Engineering Conference.

Morgantown Energy Research Center. November 14-16, 1977. Proceedings of the workshop on valves for solids handling service in coal conversion. U.S. DOE, MERC/SP-78/4.

Morgantown Energy Technology Center. July 1980 . In-service performance results for a 10-inch CVD tungsten-coated lockhopper valve. (Gardner, J. F.).

October 15-17, 1980. Proceedings of the 2nd symposium on valves for coal conversion and utilization. U.S. DOE and Valve Mfg. Assn. DOE/MC7 14522-1.

SP-i84.

January 1981. Topical report -- fixed-bed gasification. DOE/METC/

January 1983. Topical report -- lockhopper valve testing and development program. DOE/METC/SP-193. 
Moyes, A. J., and S. Vasan. September 2, 1974. Holmes-Stretford $\mathrm{H}_{2} \mathrm{~S}$ removal process proved in use. 0 il and Gas Journal.

Nakaishi, C. V. May 1982. METC ceramic corrosion/erosion studies -- turbine materials screening tests in high-temperature, low-Btu, coal-derived gas combustion products. DOE/METC-82-46.

The Pritchard Companies. no date. Clean up gas streams in one easy step by the Stretford process.

Wilson, Marvin W., and Larry A. Bissett. October 1978 . Development and operation of METC 42-inch gasifier during 1964-1977. METC/RI-78/12. 


\begin{tabular}{|c|c|c|c|c|}
\hline Run No. & \multicolumn{2}{|c|}{ Date } & Coal Type & $\frac{\text { Duration }}{\text { (hours) }}$ \\
\hline Phase I. & \multicolumn{2}{|c|}{ Gasifier Tests } & & \\
\hline 1 & $10-22-67$ & $10-24-67$ & Anthracite & 21 \\
\hline 2 & $10-30-67$ & $11-04-67$ & Anthracite & 100 \\
\hline 3 & $11-06-67$ & $11-10-67$ & Anthracite & 73 \\
\hline 4 & $11-27-67$ & $12-01-67$ & Anthracite & 90 \\
\hline 5 & $12-04-67$ & $12-09-67$ & Anthracite & 78 \\
\hline 6 & $12-11-67$ & $12-16-67$ & Anthracite & 76 \\
\hline 7 & $03-11-68$ & $03-12-68$ & Anthracite & 28 \\
\hline 8 & $03-18-68$ & $03-22-68$ & Anthracite -- Ohio \#8 & $59-40$ \\
\hline 9 & $04-08-68$ & $04-10-68$ & Anthracite & 51 \\
\hline 10 & $04-15-68$ & $04-19-68$ & Anthracite & 88 \\
\hline 11 & $04-22-68$ & $04-24-68$ & Anthracite & 46 \\
\hline 12 & $04-29-68$ & $05-03-68$ & Anthracite & 86 \\
\hline 13 & $05-13-68$ & $05-17-68$ & Anthracite & 97 \\
\hline 14 & $05-20-68$ & $05-24-68$ & $\begin{array}{l}\text { Anthracite -- } \\
\text { Lower Cedar Grove }\end{array}$ & $43-50$ \\
\hline 15 & $06-10-68$ & $06-14-68$ & Anthracite & 100 \\
\hline 16 & $06-17-68$ & $06-21-68$ & Anthracite & 87 \\
\hline 17 & $06-24-68$ & $06-28-68$ & Anthracite & 99 \\
\hline 18 & $07-29-68$ & $08-02-68$ & Anthracite & 65 \\
\hline 19 & $09-09-68$ & $09-12-68$ & Anthracite & 90 \\
\hline 20 & $09-20-68$ & No data & $\begin{array}{l}\text { Run shut down, } \\
\text { water leak in producer }\end{array}$ & \\
\hline 21 & $10-07-68$ & $10-10-68$ & Lower Cedar Grove & 109 \\
\hline 22 & $11-04-68$ & $11-08-68$ & Anthracite & 112 \\
\hline 23 & $04-07-69$ & $04-09-69$ & Lower Cedar Grove & 23 \\
\hline 24 & $04-09-69$ & $04-11-69$ & Lower Cedar Grove & 24 \\
\hline 25 & $06-02-69$ & $06-06-69$ & Lower Cedar Grove & 25 \\
\hline 26 . & $06-16-69$ & $06-17-69$ & Lower Cedar Grove & 50 \\
\hline
\end{tabular}


Run No. Start $\frac{\text { Date End Coal Type Duration }}{\text { Thours) }}$

\begin{tabular}{|c|c|c|c|c|c|}
\hline 27 & $08-05-69$ & $08-08-69$ & Anthracite -- Lignite & $\operatorname{Mix}$ & 90 \\
\hline 28 & $08-11-69$ & $08-12-69$ & Anthracite -- Lignite & $\operatorname{Mix}$ & 34 \\
\hline 29 & $08-21-69$ & $08-22-69$ & Arkwright & & 23 \\
\hline 30 & $10-06-69$ & $10-14-69$ & Lower Cedar Grove & & 105 \\
\hline 31 & $10-15-69$ & $10-16-69$ & Ohio No. 8 & & 40 \\
\hline 32 & $10-27-69$ & $10-28-69$ & Ohio No. 3 & & 44 \\
\hline 33 & $11-17-69$ & $11-19-69$ & Arkwright & & 52 \\
\hline 34 & $06-15-70$ & $06-19-70$ & Anthracite & & 38 \\
\hline 35 & $06-22-70$ & $06-22-70$ & N. D. Lignite & & 19 \\
\hline 36 & $\ddot{u} \ddot{b}-2 \dot{y}-7 \dot{0}$ & $\dot{U} 7-\dot{U}-7 \dot{U}$ & N. U. Lignite & & 1 \\
\hline 37 & $07-14-70$ & $07-17-70$ & N. D. Lignite & & 14 \\
\hline 38 & $07-22-70$ & $07-24-70$ & Arkwright & & 24 \\
\hline 39 & $09-14-70$ & $09-17-70$ & Illinois No. 6 & & 73 \\
\hline 40 & $09-28-70$ & $10-02-70$ & Arkwright & & 90 \\
\hline 4 & N 0 & $T E S T$ & . & & \\
\hline 42 & $08-30-71$ & $09-02-71$ & Arkwright & & 92 \\
\hline 43 & $.09-13-71$ & $09-16-71$ & Arkwright & & 78 \\
\hline 44 & $09-20-71$ & $09-24-71$ & Middle Kittanning & & 51 \\
\hline 45 & $10-04-71$ & $10-07-71$ & Middle Kittanning & & 57 \\
\hline 46 & $10-18-71$ & $10-22-71$ & $\begin{array}{l}\text { Middle Kittanning } \\
\text { Upper Freeport. }\end{array}$ & & $39-29$ \\
\hline 47 & $11-08-71$ & $11-10-71$ & Upper Freeport & & 43 \\
\hline 48 & $11-15-71$ & $11-17-71$ & Anthracite & & 57 \\
\hline 49 & $11-29-71$ & $12-03-71$ & Upper Freeport & & 37 \\
\hline 50 & NO & $T E S T$ & & & \\
\hline 51 & $05-24-72$ & $.05-26-72$ & Loveridge & & 39 \\
\hline 52 & $06-12-72$ & $06-14-72$ & Loveridge & & 51 \\
\hline 5 & $06-26-72$ & $06-29-72$ & Upper Freeport & & 55 \\
\hline & NO & TES T & & & \\
\hline
\end{tabular}




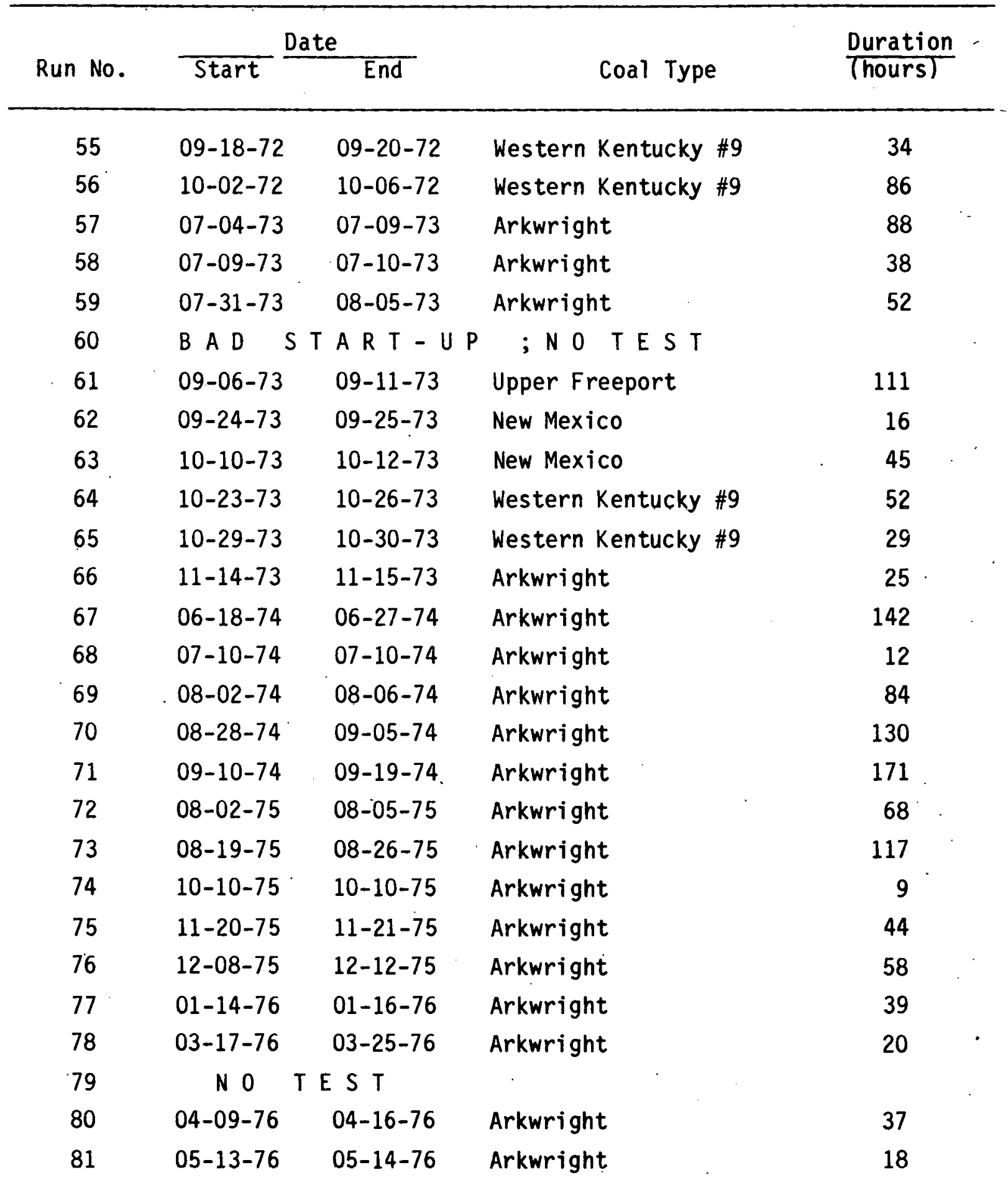




\begin{tabular}{|c|c|c|c|}
\hline : $\cdot$ & Date' & & Duration \\
\hline Run No. & Start & Coal Type & (hours) \\
\hline
\end{tabular}

Phase II. Side-Stream Cleanup Tests

First Side-Stream Cleanup Test Series

$\begin{array}{llllr}82 . & 06-04-76 & 06-04-76 & \text { I11inois \#6 } & 7 \\ 83 & 06-23-76 & 06-29-76 & \text { Iilinois \#6 } & 68 . \\ 84 & 07-23-76 & 07-25-76 & \text { Rosebud-Anthracite Mix } & 48\end{array}$

Second Side-Stream cieanup Test Series

$\begin{array}{rrrlr}85 & 12-07-76 & 12-16-76 & \text { Arkwright } & 79 \\ 86 & 03-29-77 & 04-02-77 & \text { Arkwright } & 96 \\ 87 & 06-17-77 & 06-18-77 & \text { Arkwright } & 54 \\ 88 & 08-22-77 & 08-31-77 & \text { Arkwright } & 170\end{array}$

Third Side-Stream Cleanup Test Series

$\begin{array}{llllr}89 & 10-25-77 & 10-29-77 & \text { Arkwright } & 75 \\ 90 & 12-04-77 & 12-15-77 & \text { Arkwright } & 154\end{array}$

Phase 1II. Initial Full-Flow Cleanup Tests

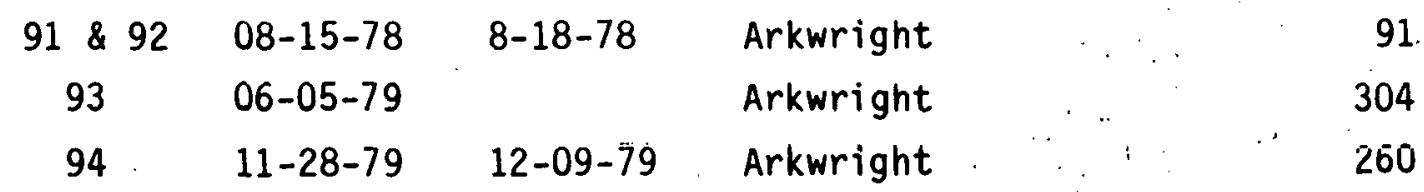

Phase IV. Full-Flow/Sulfur Removal Cleanup Tests

$\begin{array}{rrrlr}95 & 09-03-80 & 10-03-80 & \text { Arkwright } & 608 \\ 96 & 11-11-80 & 11-22-80 & \text { Arkwright } & 270 \\ 97 & 05-27-81 & 06-16-81 & \text { Arkwright } & 383 \\ 98 & 07-16-81 & 08-19-21 & \text { Kittanning } & 733 \\ 99 & 03-14-82 & 03-31-82 & \text { Arkwright } & 286 \\ 100 & 06-14-82 & 06-18-82 & \text { Arkwright } & 96\end{array}$

